Florida International University FIU Digital Commons

3-4-2008

\title{
A Comparative Analysis of Corporate Finance in the United States and Japan From 1880 to 1930
}

Yumiko Morii

Florida International University

DOI: $10.25148 /$ etd.FI08121909

Follow this and additional works at: https://digitalcommons.fiu.edu/etd

\section{Recommended Citation}

Morii, Yumiko, "A Comparative Analysis of Corporate Finance in the United States and Japan From 1880 to 1930" (2008). FIU Electronic Theses and Dissertations. 19.

https://digitalcommons.fiu.edu/etd/19 


\title{
FLORIDA INTERNATIONAL UNIVERSITY
}

Miami, Florida

\section{A COMPARATIVE ANALYSIS OF CORPORATE FINANCE IN THE UNITED STATES AND JAPAN FROM 1880 TO 1930}

A dissertation submitted in partial fulfillment of the requirements for the degree of DOCTOR OF PHILOSOPHY

\author{
in \\ HISTORY \\ by \\ Yumiko Morii
}

2008 
(C) Copyright 2008 by Yumiko Morii

All rights reserved. 


\section{DEDICATION}

I dedicate this thesis to my husband Andrey. Without him this would not have been possible. Thank you for the love and support, encouragement, and thank you for believing in me throughout my quest. I love you so much. 


\section{ACKNOWLEDGMENTS}

I would like to thank my major professors Dr. Kenneth Lipartito and Dr. Mira Wilkins and extend thanks to my committee: Dr. Steven Heine and Dr. Laura Nenzi for their support and patience, and continuous encouragement. Special thanks to Dr. Paul Miranti for his useful advice about methodology in this research. 
ABSTRACT OF THE DISSERTATION

A COMPARATIVE ANALYSIS OF CORPORATE FINANCE IN THE UNITED

STATES AND JAPAN FROM 1880 TO 1930

\author{
by \\ Yumiko Morii \\ Florida International University, 2008 \\ Miami, Florida

\section{Professor Kenneth Lipartito, Co-Major Professor \\ Professor Mira Wilkins, Co-Major Professor}

This study explained the diversity of corporate financial practices in two nations. Existing studies have emphasized the reliance on equity finance in U.S. firms and bank loans in Japanese firms. In fact, patterns of corporate finance were much more complex. Financial institutions, which were created by national economic policy and regulation, affected corporate financial practices, but corporate financial practices often differed from what policymakers expected. Differences in corporate financial practices between nations also reflected differences in the mixture of industries in each nation. Many factors such as the amount of fixed capital, the process of production, the level of risk, the degree of innovation, and the importance of the industry in the national economy affected corporate financial practices. In addition, corporate financial practices within each nation differed from firm to firm due to managers' considerations about stock ownership, which would affect their control power; corporate finance was closely related to control over management through ownership. 
To explain these complexities of corporate financial practices, the study linked corporate finance with the development of financial institutions in the United States and in Japan. While financial institutions affected corporate financial practices, the response of the firms to financial institutions and opportunities were diverse. The study also attempted to grasp variations in corporate financial practices by dealing with companies in three sectors: railroads, public utilities, and manufacturing. Finally, the study examined the structure of firm ownership. Contradictory to the widely held belief that U.S. firms distributed securities more widely to the public than did Japanese firms, many large American firms remained closely held, while some Japanese counterparts built publicly-held corporations. 


\section{TABLE OF CONTENTS}

CHAPTER

PAGE

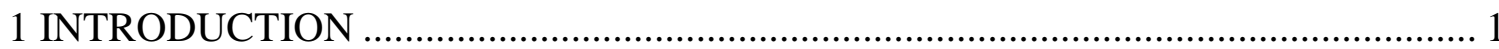

1.1 National Patterns of Capitalist Systems and Corporate Financial Practices............. 1

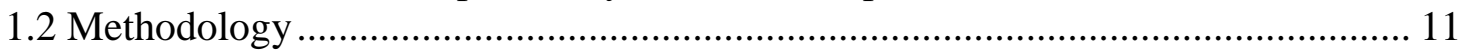

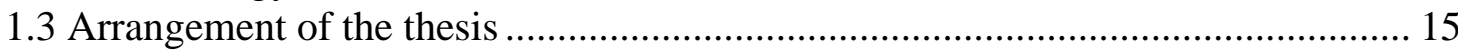

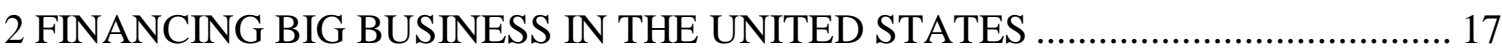

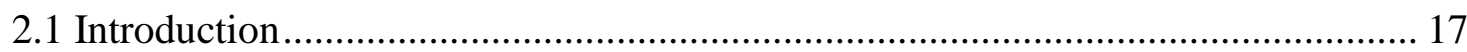

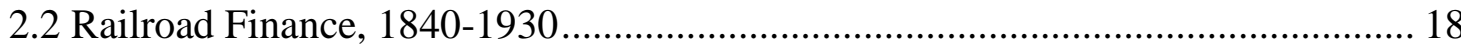

2.2.1 Financial Institutions and Railroad Finance before the 1880s ........................ 18

2.2.2 The Expansion of Railroad and Railroad Finance from 1880 to 1914 ............. 21

2.2.2.1 Financing Reorganization .................................................................. 25

2.2.2.2 The Decline of the Railroad Industry before World War I ....................... 27

2.2.3 Railroad Finance from World War I to 1930 ………....................................... 29

2.2.4 The Pennsylvania Railroad Company .............................................................. 33

2.2.4.1 Corporate Finance before World War I ................................................. 33

2.2.4.2 Corporate Finance during and after World War I...................................... 40

2.3 Public Utility Finance, 1870-1920 ........................................................................ 44

2.3.1 Corporate Finance before World War I ........................................................ 44

2.3.2 Corporate Finance from World War I to 1930................................................. 47

2.3.3 The American Telephone \& Telegraph Company ........................................... 50

2.3.3.1 Corporate Finance before World War I ................................................. 50

2.3.3.2 Corporate Finance from World War I to 1930 ………………................... 59

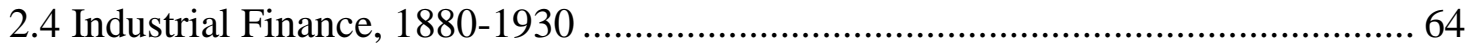

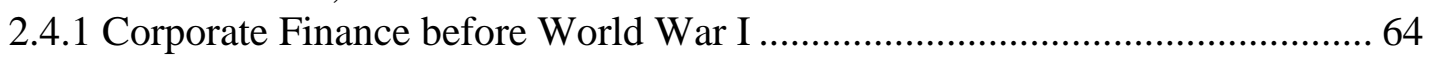

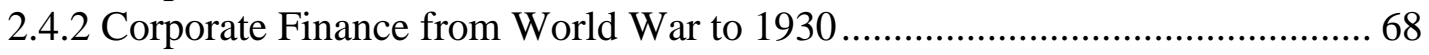

2.4.3 The United States Steel Corporation............................................................... 71

2.4.3.1 Corporate Finance before World War I ………….................................. 71

2.4.3.2 Corporate Finance from World War I to 1930_......................................... 77

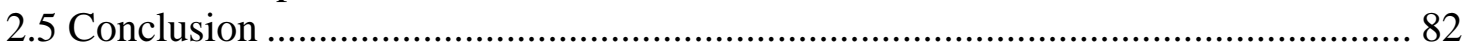

3 VARIETIES OF CORPORATE FINANCE IN JAPANESE

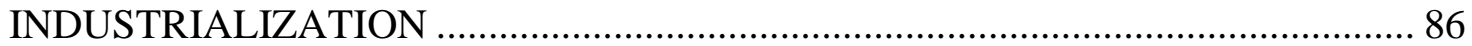

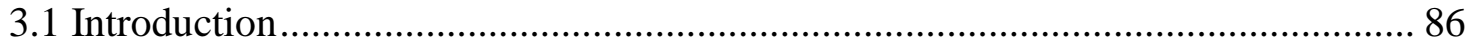

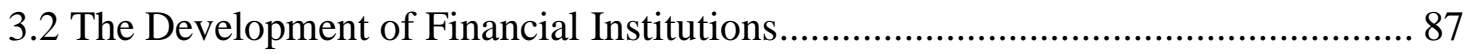

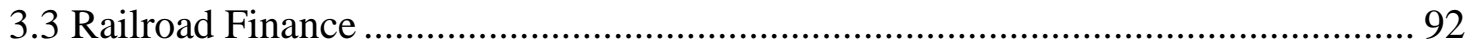

3.3.1 Corporate Finance in the Nihon Railway...................................................... 98

3.4 Public Utility Finance - Electric Utilities ........................................................... 105

3.4.1 Electric Utility Finance before World War I .............................................. 105

3.4.2 Electric Utility Finance from World War I to 1930....................................... 108

3.4.3 Tokyo Electric Light Company ………………….................................... 112

3.4.3.1 Corporate Finance before World War I ............................................... 112

3.4.3.2 Corporate Finance from World War I to 1930....................................... 118

3.5 Cotton Spinning Finance............................................................................... 124 


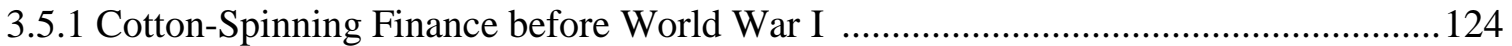

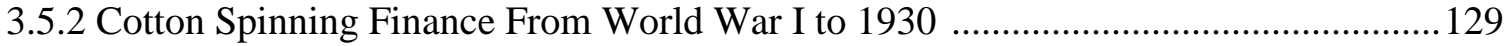

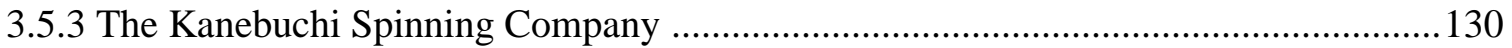

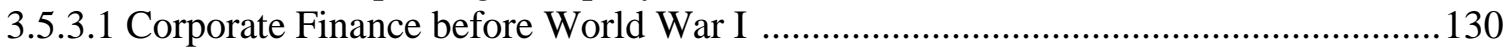

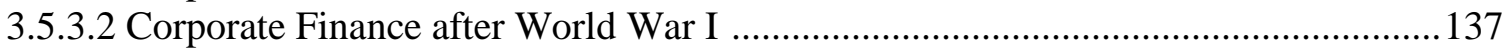

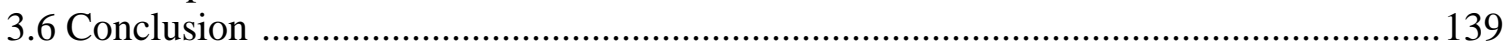

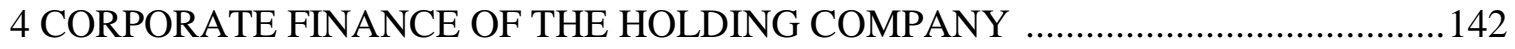

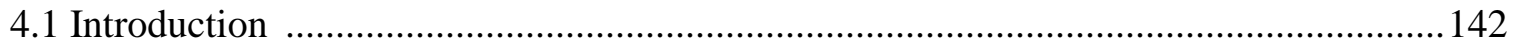

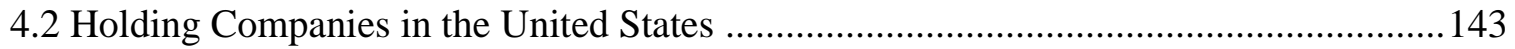

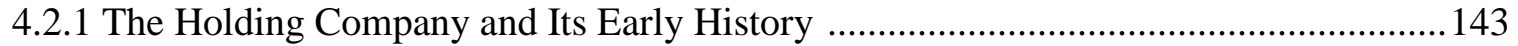

4.2.2 The Holding Company in the United States before World War I ..............................147

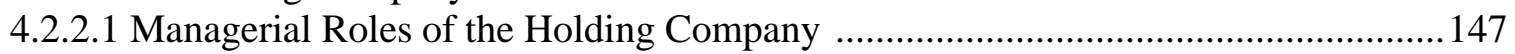

4.2.2.2 Financial Roles of the Holding Company ............................................................. 149

4.2.2.3 Concentration and the Problems of the Holding Company .....................................151

4.2.3 The Holding Company in the United States during and after World War I ..................153

4.2.3.1 Pure Holding Company versus Parent Company ..................................................158

4.2.3.2 Securities Market and Banks versus Holding Company ........................................160

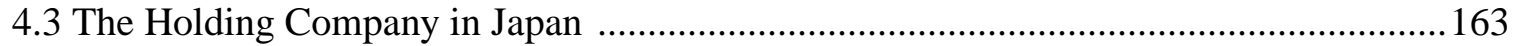

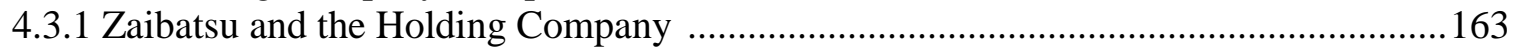

4.3.1.1 Early History of Zaibatsu and the Holding Company System ...............................163

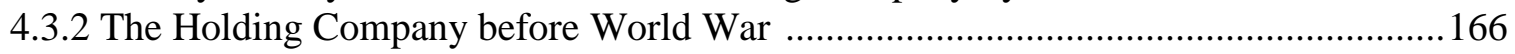

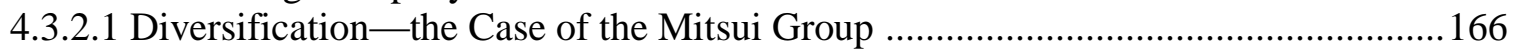

4.3.2.2 The Financial Role of the Holding Company - the Mitsui Gomei Kaisha ...............171

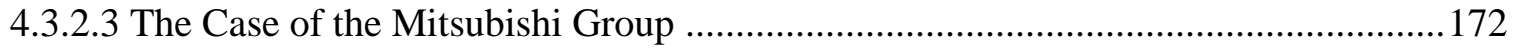

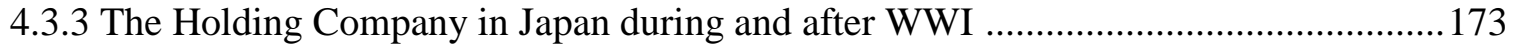

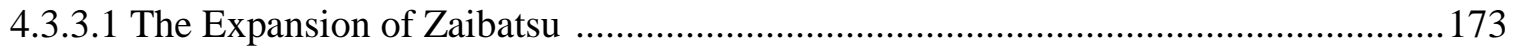

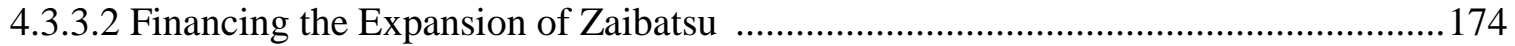

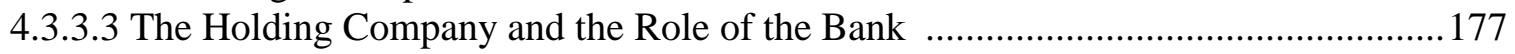

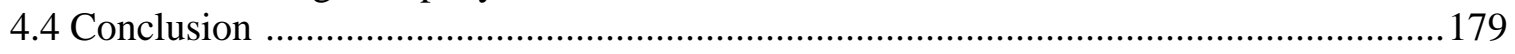

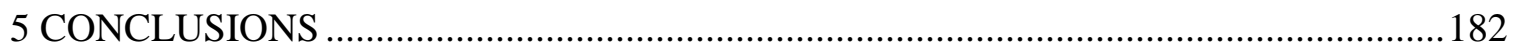

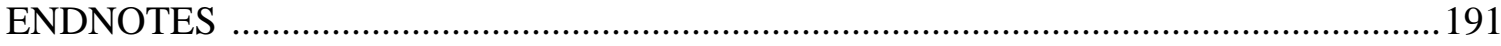

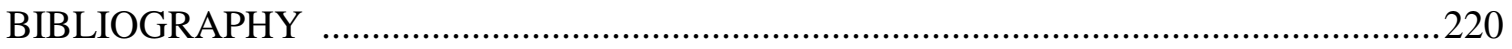

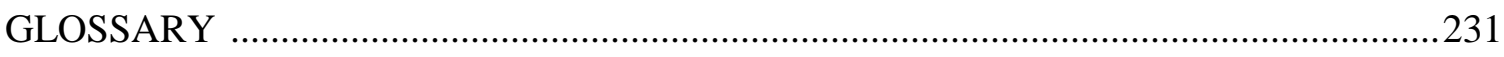

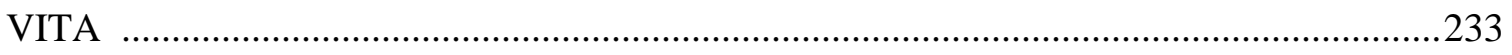




\section{LIST OF TABLES}

TABLE

PAGE

Table 1: U.S Securities Markets, Sales in 1910 ........................................................... 21

Table 2: Long-Term Finance of the Pennsylvania Railroad Company .......................... 35

Table 3: The Number of Shares and Shareholders of the Pennsylvania Railroad ............ 36

Table 4: Long-Term Finance of the Pennsylvania Railroad after 1914......................... 42

Table 5: Assets of the American Telephone \& Telegraph Company .............................. 52

Table 6: Long-Term Finance in the American Telephone \& Telegraph Company .......... 54

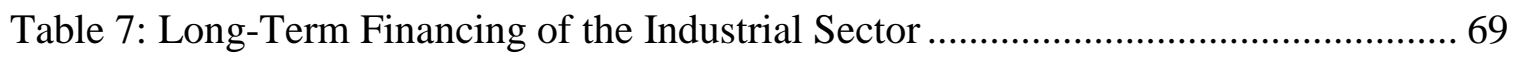

Table 8: Paid-in Capital per Firm in Three Major Industries ..................................... 93

Table 9: The Ratio of Net Income to Common stock ............................................ 99

Table 10: Equity Finance of the Nihon Railway ................................................... 101

Table 11: The Number of Shares held by the Major Shareholders............................... 104

Table 12: Equity and Debts in the Electric Utility Industry .................................... 106

Table 13: The Increase in Long-Term Finance of the Electric Utility Industry ............. 109

Table 14: Foreign Bond Issues of the Electric Utility Companies .............................. 110

Table 15: Long-Term Finance of the Tokyo Electric Light Company ......................... 114

Table 16: Shareholding of the Tokyo Electric Light Company ................................... 116

Table 17: Stock and Bonds of the Tokyo Electric Light Company after 1914.............. 118

Table 18: Reserves of the Tokyo Electric Light .................................................. 123

Table 19: Fixed assets and Equity of the Cotton Spinning Industry ........................... 125

Table 20: The Ratios of Financial Sources to Gross Assets ...................................... 128

Table 21: Long-Term Finance of the Kanebuchi Spinning ....................................... 133 
Table 22: Financial Sources of the Kanebuchi Spinning from 1923 to $1930 \ldots \ldots \ldots \ldots \ldots . . . . . .138$

Table 23: Retained Earnings of the Kanebuchi Spinning ........................................... 138 
Figure 1: The Ratio of Accumulated Internal Funds to Gross Assets. ............................... 39

Figure 2: The Ratio of Internal Funds to Gross Assets of the Pennsylvania Railroad. .... 42

Figure 3: The Number of Shares per shareholder in the Pennsylvania Railroad.............. 43

Figure 4: The Increase in the Amount of Stock Outstanding and................................... 57

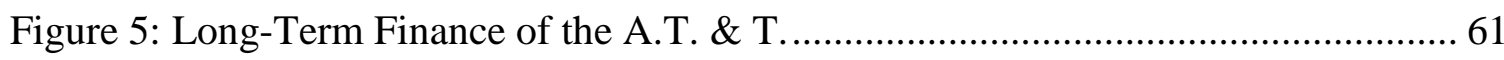

Figure 6: The Number of Shareholders in the American Telephone \& Telegraph

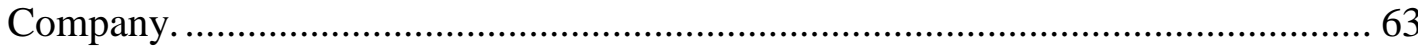

Figure 7: The Ratio of Retained Earnings to Gross Assets in the A.T. \& T...................... 63

Figure 8: Capital/Output Ratio for U.S. Utilities, Transportation, and Manufacturing.... 66

Figure 9: Gross Assets and Fixed Assets of the United States Steel. ................................ 73

Figure 10: Stocks and Bonds Outstanding of the United States Steel. ............................ 75

Figure 11: The Increase in Gross Assets of the U.S. Steel. ............................................. 78

Figure 12: The Ratio of Internal Funds to Gross Assets in the U.S. Steel. ...................... 79

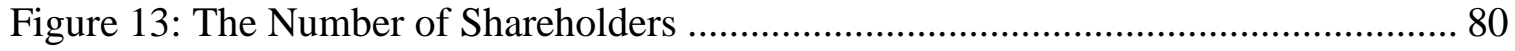

Figure 14: The Average Number of Shares per Shareholder in the Nihon Railway ..... 102

Figure 15: The Increase in Gross Assets of the Kanebuchi Spinning............................. 131

Figure 16: The Number of Share of the Kanebuchi Spinning Transferred..................... 132 


\section{Chapter 1}

\section{INTRODUCTION}

\subsection{National Patterns of Capitalist Systems and Corporate Financial Practices}

After the collapse of the communist economic system in the late twentieth century, the world economy seemed to converge on capitalism. However, not all forms of capitalism are the same. In his book, Scale and Scope, Alfred D. Chandler Jr. classifies the forms as personal capitalism, as in Britain, competitive managerial capitalism, the pattern in the United States, and cooperative managerial capitalism, as exemplified by Germany.[1] Peter A. Hall divides capitalism into coordinated market economies in Germany and Japan and liberal market economies in Britain and the United States. [2] J. Rogers Hollingsworth also points out that the Japanese system is based on a collective form of economic coordination, and in contrast, the American one on a market-oriented form. [3] Thus, international economic and business historians have attempted to clarify the distinctive patterns of the national economies. They often argue that national differences are attributable to path dependency. That is, the diversity of history and culture among nations created distinctive economic systems that continue over time through their own logic. This prevents convergence on a single economic model. [4]

Similarly, existing studies classify part of capitalist systems, corporate finance, according to national patterns. The classic works to explain national patterns of corporate finance are Adolf A. Berle and Gardiner C. Means, The Modern Corporation and Private Property, published in 1932, and Alexander Gerschenkron's Economic Backwardness in Historical Perspective, published in 1962. According to Berle and Means, the 
transformation of numerous private businesses into a small number of large corporations in the United States led to the wide distribution of stock and the separation of ownership and control. As the size of corporations expanded, "ownership was so widely distributed that no individual and small group has even a minority interest large enough to dominate the affairs of the company." [5] Shareholders thus surrendered control over their wealth to managers of the corporation. Shareholders became simply suppliers of capital. Berle and Means use as examples three large companies, the Pennsylvania Railroad Company, the American Telephone and Telegraph Company, and the United States Steel Corporation. In all of the three companies, any principal shareholder in 1929 held less than 1 per cent of the outstanding shares and the twenty largest owned less than 5.1 per cent. [6] Thus, Berle and Means associated corporate financial practices with the size of companies. American big businesses serving a huge domestic market were destined to move toward the concentration of capital, wide distribution of ownership, and the separation of ownership and control.

On the other hand, Gerschenkron related corporate financial practices to the timing of industrialization. The more backward the country, he explained, the greater the "spur" of its economic growth. Therefore, advanced countries like England experienced the gradual process of industrialization, which "obviated the pressure for developing any institutional devices for provision of long-term capital to industry." In fact, industrialization in England dispensed with "substantial utilization of banking for longterm investment purposes." [7] In contrast, relatively backward countries required a considerable amount of capital in a short time to deal with the rapid process of industrialization. However, capital in those countries was scarce and diffused. In 
addition, investors" "distrust of industrial activity," huge fixed costs associated with the formation of big business, and "the scarcity of entrepreneurial talent" in the backward country hampered efforts to raise funds. [8] Under these circumstances, a banking system for supplying long-term funds was indispensable for industrialization. In more backward countries, however, no banking system was able to raise enough funds to finance industrialization due to extreme "scarcity of capital," "the low standards of honesty in business," and the general distrust of the public. [9] Financing industrialization required "the compulsory machinery of the government."[10] According to Gerschenkron, timing of industrialization determined corporate financial practices.

Deeply influenced by these classics, scholarship has emphasized national patterns of corporate finance. In their recent A History of Corporate Governance around the World, Randall Morck and Lloyd Steier divided capitalism in terms of finance. Britain and the United States represent shareholder capitalism, in which firms issue stock and bonds to investors to raise funds for industrial activity. On the other hand, post-war Germany and Japan belong to bank capitalism, where investors put money in the bank and then the bank lends the money to companies for long-term funds. Sometimes, the bank also invests in companies by purchasing their securities. [11] In Comparing Financial Systems, Franklin Allen and Douglas Gale also classified corporate financial system as market-oriented and bank oriented. They listed the United States and Germany as the polar opposites; the former is based on market-led system and the latter on bank oriented system. Many other countries are located between the two poles.

Assuming the national patterns, some scholars focus on the determinants of corporate financial practices. In The Visible Hand, Chandler explains that the size and the 
evolution of complex organization in modern corporations related to corporate financial practices in the United States. In the nineteenth century, he explains, entrepreneurs and their partners funded small scale family enterprise by themselves. In this stage, owners maintained control over their firms. As the size of firms expanded in railroad companies in the last half of the nineteenth century, railroad owners began to rely on bankers who had access to other financial sources. In return for financial support from bankers, owners had to accept bankers' intervention in management. Finally, after World War I when firms achieved immense scale and scope, shares of modern corporations were widely distributed in the public to raise huge amount of funds from broader sources. While the ownership was diffused to the general public, professional managers controlled management of the firms. [12]

Meanwhile, Wendy Carlin and Colin Mayer argue that the nature of productive activity of firms determines the suitable corporate financial practices in any nation. They state that market-oriented financial systems and widely distributed ownership (for example, in the United Kingdom and the United States) are associated with innovative, high-risk activities. The wide distribution of ownership distributes high risk to many shareholders, and the resulting managerial autonomy makes firms more flexible to change. On the other hand, bank-oriented systems (for example, in Germany and Japan) are closely related to longer-term investment in imitative production, which often requires many stakeholders, such as suppliers and purchasers. Firms are able to concentrate ownership though the use of bank loans, which enable them to have power to protect stakeholders rather than shareholders. [13] 
Mark Roe's arguments on corporate financial practices focus on interest of stakeholders. He insists that the influence of stakeholder interests on the allocation of resources determines corporate financial practices. If political support to stakeholder interest is strong as in continental Europe and Japan, managers try to hold large controlling stakes to weaken the power of stockholders so that they can respond to other stakeholders. This strategy strengthens banks' role and reduces firms' use of the securities market. On the other hand, if stakeholders do not have political power, as in the United States, mechanisms such as transparent accounting and a vigorous market for corporate control develop, which contribute the development of the securities market and facilitate the wide distribution of ownership. [14]

Rafael Laporta, Franco Lopez-de Silanes, Andrei Schleifer, and Robert Vishny argue that legal traditions of minority shareholders and creditors create the national patterns of corporate finance. In the common law country such as Britain and the United States, publicly held corporations prevail because minority shareholders and creditors are protected from the exploitation of large shareholders. In the meantime, in the civil law countries including Germany, France, and Japan, firms tend to retain the majority of ownership due to less legal protection to minority shareholders and creditors. [15]

Finally, John Zysman insists that financial institutions, which are politically created, affected the degree of government intervention in the economy and corporate governance after World War II. He classifies financial systems as state-led, market-led and negotiated (bank-led) systems. He maintains that in Japan, under a state-led system, the government deterred the use of the securities market and facilitated financing from banks by keeping interest rates low. It also guaranteed bank loans as a last resort to 
diminish the risk of debt financing. In the United States, in contrast, the market-led financial system, characterized by decentralization and a strong securities market, minimized the role of the banks and the government. [16]

Thus, existing studies widely accept national patterns of corporate finance, similar to the division of capitalist systems by national patterns. However, as I will argue, patterns of corporate finance were much more complex in reality. Financial institutions, which were created by national economic policy and regulation, affected corporate financial practices, but corporate financial practices often differed from what policymaker expected. Differences in corporate financial practices between nations also reflected differences in the mixture of industries in each nation. Many factors such as the amount of fixed capital, the process of production, the level of risk, the degree of innovation, and the importance of the industry in the national economy affected corporate financial practices. In addition, corporate financial practices within each nation differed from firm to firm due to managers' ownership consideration; corporate finance is closely related to control over management through ownership.

This study attempts to explain these complexities through comparisons of practices and patterns in two major industrial nations, the United States and Japan, from the 1880s to 1930 . According to the Gerschenkron model, the United States during the time period was often regarded as one of the developed countries, while Japan was considered as a latecomer of industrialization. Although the Japanese economy did not exactly fit the word of "backwardness" as Gerschenkron explained, it was still considered as "backward", compared with the American economy. Quantitative data such as the structure of industrial population and of the GDP shows Japan's "backwardness" relative 
to the United States. [17] In Japan, 78 per cent of the industrial population was engaged in agriculture and fishery in 1877, and 55 per cent in 1930. The manufacturing population was much smaller. It accounted for 9 per cent of the total industrial population in 1877 and 22 per cent in 1930. Although industrialization progressed, Japan was still an agricultural country. On the other hand, the population dealing with agriculture and fishery in the United States was 50 per cent of the total industrial population in 1880 and 22 per cent in 1930, while the population engaged in manufacturing was 25 per cent in 1880 and 31 per cent in 1930. In the United States, more laborers were put in the manufacturing sector than in Japan. Similarly, in 1895, 42.7 per cent of the GDP in Japan came from agriculture and fishery and 13.2 per cent from manufacturing. Then, in 1925, 28.1 per cent came from agriculture and fishery and 19.5 per cent in manufacturing. In other words, agriculture and fishery accounted for larger amounts of the GDP than manufacturing even though the importance of manufacturing increased throughout the time in Japan. On the other hand, in the United States, manufacturing was consistently an important sector in the GDP. From 1889 to $1899,17.9$ per cent of the GDP came from agriculture and fishery, and 25.4 per cent from manufacturing. From 1919 to $1929,11.2$ per cent of the GDP came from agriculture and fishery and 23.8 per cent in manufacturing. [18] Thus, although Japan was rapidly industrialized from 1880 to 1930 , it was s a latecomer of industrialization and less industrialized, compared with the United States.

This study links corporate finance with the development of financial institutions. As Richard Sylla and George David Smith argue, “Americans' ideological hostility to concentrated financial power" led to the creation of the fragmented banking system.[19] 
In Japan, on the other hand, the government attempted to create a centralized banking system to finance industrialization in the late nineteenth century. The paths of economic and financial development in the two nations certainly influenced corporate financial practices, but the responses of companies varied. In fact, from the late nineteenth century to the early twentieth century, American firms often sold stock to a limited numbers of investors without using stock markets, while widely distributing bonds. In Japan, some firms relied on securities and others on financial support from holding companies rather than bank loans.

This study also attempts to demonstrate that corporate financial practices were different from industry to industry and even from firm to firm within an industry. When existing studies deal with the national patterns of corporate finance in the United States, they usually focus on big businesses based on mass production of standardized products. It is believed that large mass-production firms required huge amount of fixed capital to begin and expand operations, which capital mainly came from stock issues. However, the American economy was diverse, depending not only on the size of the companies but also on the production system. In Endless Novelty, Philip Scranton explores another kind of American business; specialty production firms, which make many different products to meet various and irregular consumer demands. In specialty production, managers tried to lower their fixed costs in order to make it easy to change production methods. [20] They also relied on retained earnings rather than securities issues due to the market risk of their products.

In the Japanese economy as well, not all businesses were large, although existing studies have dealt with large companies and often characterized their financial practice as 
bank oriented. In fact, during industrialization, small firms and large firms coexisted. According to William W. Lockwood, in such industries as textile and ceramics, small firms tied themselves to large ones by supplying "raw materials and services or handled certain stage of manufacturing." Small firms also contributed to the expansion of foreign trade. The strength of small firms was in part explained by "wide distribution of electric power" since the early twentieth century. This facilitated mechanization even in a small production unit. [21]

This sort of diversity among firms undercuts notions of a single national pattern of finance and capitalism. My study, however, will look at diversity from another angle - among the large firms themselves, which are typically studied by those seeking out national patterns. Small and medium firms' financial practices are relatively simple. If entrepreneurs cannot provide enough capital, they may borrow money from family members, relatives, and friends or they rely on local financial institutions. [22] As the size of companies grows, however, corporate financial practices became complicated because of the huge demand for capital and their necessity to rely on external funds. By focusing on large corporations, this study shows how they met their huge financial needs and at the same time shows the diversity of corporate financial practices among large corporations.

Also, this study shows that corporate financial practices within a nation change over time. The so-called national patterns of corporate financial practice in the two nations do not always correspond in any time period. In the United States, as Chandler explains, corporate finance was transferred from personal through financial to managerial capitalism, but managerial capitalism was not the final form. According to Michael C. 
Jensen, in the 1980s, many companies in the United States used leveraged buyouts to reduce the dispersal of ownership and eliminate the conflict between ownership and management. Through the huge amount of debt issue and the limited amount of equity held by manager-owners, managers' incentives came into line with those of owner. By paying out dividends from retained earnings, the investment in unprofitable diversification within firm was avoided. [23]

Likewise, in Japan, the reliance on bank loans was not persistent across time. Bank loan finance was closely related to corporate groups called keiretsu, which appeared after World War II. They were organized by major companies through interlocking shareholding and strong ties among firms within groups. [24] A main bank was included in each keiretsu, which played a role as a major financier for group companies. The bank not only supplied funds but also provided newly emerging modern firms with managerial skills and organizational techniques. Furthermore, the bank monitored the firms; when the firms were not well managed, it interfered with management of the firms. These bank-centered financial practices were rarely seen in zaibatsu, which were pre-World War II corporate groups and the predecessors of keiretsu. Also, the post-war bank oriented system was weakened after 1970. Kang and Stulz, Morck and Nakamura, and Weinstein and Yafeh contest the contribution of main banks in firm's profitability and the economic growth. [25] Hoshi, Kashyap, and Scharfstein, and Miyajima state that in the late 1970s, firms relied on the bond market more than bank loans due to deregulation. [26]

These changes of corporate financial practices are not compatible with the theory of path dependency. According to path dependency, financial institutions are created in 
the path of economic development and under the influence of culture. Corporate financial practices are defined by historically and culturally created financial institutions. These would not converge into a single model. The stickiness of history and culture preserved national patterns. In reality, however, corporate financial practices were dynamic. As Caroline Fohlin concludes in her research of German financial system, "[financial] systems may differ more within one country over time than they do across countries at a given time. Much of the variation and change stems from idiosyncratic factors and defies standardization." [27] Thus neither broad and distinct national patterns that persist over time nor convergence is the correct way to understand patterns of corporate finance.

\subsection{Methodology}

This study focuses on the 1880 s to 1930 . This time period is important in both nations; it covers the emergence and the evolution of big businesses in the United States and industrialization of Japan. In the United States, big businesses, which required huge amounts of funds, made the issue of corporate finance critical. In Japan, importing western institutions and technology, the nation experienced rapid industrialization. Financing industrialization came to be a serious problem in the national economy. The study divides the time period by two: from 1880 to before World War I and from World War I to 1930. World War I was a watershed that changed the path of economic development. During and after the war, both nations experienced economic booms, which significantly affected corporate financial practices. The research ends when the economic expansion stopped with the Great Depression. This economic calamity shifted corporate financial practices again by the increasing government intervention in economic activity. 
This study deals with three industrial sectors to examine patterns of corporate finance: railroads, public utilities, and manufacturing. Railroads were important because they were the first business with huge fixed costs and a corresponding need for capital. Their extensive facilities and geographical scope made them giant scale enterprises. They introduced modern corporate financial practices, which became a model of other industries in both nations. In the United States, the railroad industry heavily relied on the bond market by using investment bankers, while in Japan it facilitated the development of the stock market and relied on stock finance. Public utilities also needed large amounts of capital for facilities and the application of new technology. They mostly followed the financial practices of railroads, but their peculiar nature as "public" differentiated their financial activity from railroads. The services provided by public utilities were regarded as indispensable for the public and needed to be available to all people. Hence, public utility services were provided in wider area than that of railroads. While being allowed to monopolize the market to achieve efficient production, public utilities were subject to the government regulation of their rates and services. On the other hand, manufacturing companies were private enterprises. Due to their smaller size than railroads and utilities, manufacturing companies usually required less fixed capital. They also needed to take risk without government interference. They dominated the American and Japanese economies; big businesses emerging through vertical and horizontal integration in the United States and burgeoning modern industrials corporations in Japan played significant roles in the national economies.

In the United States, the patterns of corporate financial practice of these three sectors are examined. Instead of three industrial sectors, in Japan, three industries 
belonging to the three industrial sectors, that is, railroads, electric utility, and cotton spinning, are explained. This different handling of the United States and Japan was caused by distinct industrial structures in each nation. In the United States, important industries such as telephones in public utilities and steels in manufacturing attained de facto monopoly status. Since their corporate financial practices also formed industryspecific practices due to their monopolistic status, the research in the patterns of corporate finance in the two industries overlapped with that of major companies in the industries. On the other hand, in Japan, corporate financial practices in each sector were too diverse to generalize. In public utilities, several industries were more or less owned by the government. Also, in manufacturing, industries faced the different stages of development; some were engaged in hand-craft manufacturing and others in factory production. Therefore, instead of examining industrial sectors, two major industries were selected in addition to railroads: electric utilities, which were founded without government ownership, and cotton spinning, one of the first to achieve modernization among manufacturing.

After examining corporate financial practices in each industrial sector or industry, corporate finance of an individual firm belonging to each industrial sector or industry is studied by using financial data from annual reports. The companies dealt with are the major ones of their industry. In the United States, the Pennsylvania Railroad Company, the American Telephone and Telegraph Company, and the United States Steel Corporation, are selected. These companies were tremendously huge in size. These are also the same companies as Berle and Means used as large-scale corporations with widely held stock in the public in The Modern Corporation and Private Property. In 
Japan, the Nihon Railway Company, the Tokyo Electric Light Company, and the Kanebuchi Spinning Company are chosen. Similar to the U.S companies selected in Chapter 2, these companies were one of the biggest companies in the industry.

Thus, not all of the industries the companies belonged to are the same between the United States and Japan. This is explained in part by the difference in industrial organization and in part by the different stage of industrialization between the two nations. In the United States, the telephone industry monopolized by the A.T.\&T was the first to expand its business geographically in public utilities. In Japan, on the other hand, the telephone industry was not appropriate to be selected in this study because it was owned by the government. Instead, the electric utility industry, which prospered without government ownership, was chosen. In manufacturing, the United States Steel, also monopolizing the steel industry, was the biggest manufacturing company in the early twentieth century. Meanwhile, in Japan, similar to the telephone industry, the steel industry was owned by the government in its early years. Instead, another major industry, cotton spinning, was selected. However, cotton spinning was no longer a major industry in the United States in the early twentieth century; the size of the firms in the industry was much smaller than that of major firms in the steel, auto, and chemical industries.

Financial sources in these industries including securities, loans, and internal funds are examined in conjunction with the development of the securities market and the banking system in the United States and Japan. In addition to these financial institutions, however, holding companies came to play a significant role in financing industries in both nations. In the United States, by using the holding company system, a number of companies were consolidated into a gigantic entity with relatively small amounts of 
capital. In Japan, holding companies in family-based corporate groups called zaibatsu more or less participated in corporate finance of the major three industries - the railroad, electric light, and cotton spinning. However, their managerial and financial influence on other industries as a holding company was even larger than those of the major industries. In order to present the complexity and variety of corporate financial practices, this study presents the development of holding companies and their roles in both nations in brief.

\subsection{Arrangement of the thesis}

This study consists of three substantive chapters. Chapter 2 examines corporate financial practices in the United States in the two time periods: from 1880 to before World War I and from World War I to 1930. It focuses on the railroad, public utility, and manufacturing by using case studies of the Pennsylvania Railroad, the A.T. \& T., and the United States Steel respectively. In the three sectors, equity finance was not a major financial method, while their corporate financial practices were different from each other. The chapter also shows that corporate financial practices of the three companies differed from those of the industrial sectors they belonged to.

Chapter 3 deals with corporate financial practices in Japan in the same time periods of the United States. Specifically, it also examines three sectors (albeit with different industries): railroads, public utilities, and manufacturing. In this case, the financial data of the Nihon Railway, the Tokyo Electric Light, and the Kanebuchi Spinning are used to examine whether corporate financial practices of an individual company fit industry-specific financial practices. Although financial practices were diverse, these industries all relied on securities rather than bank loans. This chapter also shows the diversity of corporate financial practice of individual companies. 
Chapter 4 presents the development of the holding company system, its managerial and financial roles in the United States and Japan, and the corporate finance of the holding company. In the United States, first railroads and then public utility companies attempted to achieve efficiency and take financial advantages through the holding company system. Using various devices, the holding companies distributed their stocks widely in the public. Meanwhile, in Japan, this chapter examines zaibatsu. The chapter especially deals with major zaibatsu, the Mitsui, the Mitsubishi, and to a lesser extent, the Sumitomo. The zaibatsu holding company system was an efficient tool for the mixture of administrative concentration and operational autonomy of the constituent companies. Interestingly, unlike the main bank system in keiretsu after World War II, zaibatsu were reluctant to use banks as major financiers.

In conclusion, (Chapter 5), corporate financial practices of both nations are compared. Despite the distinct patterns of corporate financial practices in both nations, corporate financial practices of both nations often do not fit the nationally based models and patterns. Corporate financial practices in each nation did not always conform with what financial institutions intended. Also, corporate financial practices were diverse and changing across time. 


\section{Chapter 2}

\section{FINANCING BIG BUSINESS IN THE UNITED STATES}

\subsection{Introduction}

When economic historians have compared corporate financial practices in the United States with those of other countries, they have often contended that corporate finance in the United States was market-oriented since the 1930s. The company collects funds from the market, issuing stock to a number of shareholders. Since stock was widely held in the public, the power of owners was weakened. Instead, managers controlled the company by using their managerial expertise. This theory has been long asserted when Berle and Means published the book, The Modern Corporation and Private Property.[28]

This chapter shows that corporate financial practices of the major industries in the United States from the 1880 s to the 1930 s were not always compatible with the conventional idea of the reliance of American companies on the stock markets. In fact, major sectors such as railroads, public utilities, and to a lesser extent, big industrial businesses often relied on bonds and internal funds including depreciation accrual, reserves and undistributed earnings to meet their huge financial demands. This chapter also shows that there were a variety of corporate financial practices that differed from sector to sector and even from firm to firm. Many factors such as the size of the business, monopolistic power, and nature and risk of business, economic policy, and corporate preference created firm-specific as well as sector-specific corporate financial practices. 


\subsection{Railroad Finance, 1840-1930}

\subsubsection{Financial Institutions and Railroad Finance before the 1880s}

The development of financial institutions in United States history has reflected strong public sentiments distrustful of monopolistic power and financial concentration. In the first half of the nineteenth century, the First and Second Bank of the United States, which expected to function like a central bank, ceased to exist in part because of the antagonism toward monopolistic financial power. Without financial control by a central bank, American banking system remained decentralized. Financial activities of statechartered banks were typically limited to the state level. A large number of small nonchartered banks appeared as many states enacted Free Banking laws, which permitted free entry into banking business. But these moves also promoted still more decentralization. Even when the federal government attempted to regulate banking activity during the Civil War, the banking system failed to be centralized. Although the National Banking Act of 1864 aimed to replace state-chartered banks with federallychartered banks, the prohibition of branch banking and the minimum capital requirement for national banks hampered the establishment of the national banking system.[29]

This decentralized banking system facilitated the development of the securities market, which served American industrialization. The key to its evolution was the emergence of the railroad, the first industry to require a huge amount of fixed capital. In the very beginning, the railroad was still a local transportation, which could be financed by the sale of stock to local investors. Railroads' relatively small demand for capital was met without bond issues and did not require the integration of the local securities markets. [30] However, the railroad construction boom from the late 1840s facilitated the 
development of a broader securities market.[31] Particularly, the New York Stock Exchange became a dominant securities market, where securities all over the United States were traded by the mid 1850s.[32]

With the development of the securities market, many investors outside the local region began to subscribe railroad bonds. Not only the investors in the United States but also those in Europe who lost investment opportunity due to the Revolution of 1848 were eager to invest in American railroads. In fact, from 1848 to 1853, American railroads obtained German, French, Swiss and British capital. In 1852, American railroad bonds were issued to the public in London for the first time. [33] Foreign investors regarded railroad bonds as safe next to U.S. federal and state bonds; they were confident in American railroad bonds because these bonds were sponsored by respected investment bankers, who connected the demand of railroads and the supply of funds. These were private bankers whose financial activity was not regulated by state and federal laws. Taking advantage of their freedom, they underwrote railroad securities to provide client companies the assurance of sales and then sold those securities across national borders through their connections with European countries. [34]

Despite the contribution of investment bankers, their role as financiers in American business should not be exaggerated before the 1870s. According to Vincent P. Carosso, they were engaged in financing trade and dealing in commodities as merchant banks rather than selling securities. In addition, often times, they merely participated in London houses' securities business due to their deep reliance on the London market. [35]

It was the strategic change of railroad industry that developed the financial function of investment bankers. Before the 1870s, railroad companies had made use of 
"informal alliances with connecting and competing roads," to avoid loss from excessive competition. [36] However, the strategy was no longer possible when the informal cooperation was busted after the depression of 1873 . Now, railroad managers sought to obtain power to control the industry through geographical expansion. Railroad companies constructed extensive lines, purchased additional cars, and consolidated existing railroad companies, which increased their financial burdens. To finance the expansion, they began to rely heavily on investment bankers. Responding to the financial demand of railroads, investment bankers began to use syndicates of "fellow bankers and agents," which enabled them to raise huge amounts of capital at reduced risk to the underwriters. Each member of the syndicate had responsibility for the underwriting or selling securities allocated, and in the end, the profit or loss made through these transactions were divided among member firms. The Pennsylvania Railroad was the first private enterprise to be financed by the syndicate to create a gigantic railroad system. From 1869 to 1873 the company "sold or otherwise disposed of $\$ 87$ million worth of securities". [37] This security issue was huge; it is equivalent to $\$ 1.4$ billion in 2006. [38] While it sold most of stock to the existing shareholders and other American investors by itself, the syndicate was responsible for the sale of bonds assigned. [39]

Thus, before industrial big businesses emerged, the American financial system based on the securities was already formed. However, the securities market dealt with much larger amount of bonds than stock. Ronald Michie shows that, in 1910, all U.S. securities markets—New York, Boston, Philadelphia, Chicago—sales stocks amounted to $\$ 239.8$ million and sales bonds to $\$ 700.5$ million. [40] Investment bankers distributed the bonds, which strengthened the power of bankers in railroad management. (Table 1) 
(in Million Dollars)

\begin{tabular}{|l|r|r|r|r|}
\hline \multirow{2}{*}{ Market } & \multicolumn{2}{|c|}{ Stocks } & \multicolumn{2}{c|}{ Bonds } \\
\cline { 2 - 5 } & Number & Proportion & $\begin{array}{l}\text { Par } \\
\text { Value }\end{array}$ & Proportion \\
\hline New York & 215.1 & $89.7 \%$ & 645.8 & $92.1 \%$ \\
\hline Boston & 15.5 & $6.5 \%$ & 32.7 & $4.7 \%$ \\
\hline Philadelphia & 8.3 & $3.5 \%$ & 14.6 & $2.1 \%$ \\
\hline Chicago & 0.9 & $0.4 \%$ & 7.4 & $1.1 \%$ \\
\hline \multicolumn{1}{|c|}{ Total } & 239.8 & $100.1 \%$ & 700.5 & $100.0 \%$ \\
\hline \multicolumn{4}{|c|}{ Source: Michie, $\mathrm{p} 170$}
\end{tabular}

Table 1: U.S Securities Markets, Sales in 1910

\subsubsection{The Expansion of Railroad and Railroad Finance from 1880 to 1914}

After 1880, railroad companies grew rapidly in size. They extended additional lines and facilitated consolidation to create cooperation and harmony in the industry. This movement was, however, irreconcilable with public sentiment of anti-monopoly. To justify their concentrated power, railroad companies insisted on the compatibility of monopolistic power and public goods. President of Pennsylvania Railroad, Alexander J. Cassatt, justified consolidation and cooperation by using the term of community of interest; "the ownership of shares of rival lines in sufficient amounts to obtain representation upon their boards of directors would maintain harmony among roads" and, in turn, contributed "community of interest." [41]

The desire of railroad officials to control competition was supported by economic policies at the time. The Interstate Commerce Act of 1887 unintentionally encouraged consolidation. The act responded to popular protest against consolidation and fear of monopoly. It called for "just and reasonable rates," forbade "a greater charge for a short haul than for a long haul," and prohibited "all preference not only as between individuals but as between localities". The act also ruled out pooling in railroads and other industries. 
The result of the Act was, however, different from what the lawmakers intended: it did not hamper the increasing power of monopoly but strengthen it. As the Commercial and Financial Chronicle states, "The long-and short-haul clause has favored to large distributing centers at the expense of the smaller ones. The prohibition of pools has made it harder for weak and short roads to live." [42]

Similarly, the Sherman Anti-trust Act of 1890 accelerated the movement of consolidation. The Act prohibited any contracts and combinations to restrain trade. The prohibition of cartels and trust arrangement led railroad companies to consolidation, which was the only means left to them to avoid destructive competition. [43] As a result of the weariness toward excessive competition of railroad directors and the unintended results of anti-monopoly policies, the industry became highly concentrated. In 1906, twothirds of the mileage of railroads in the United States was controlled by seven groupsthe Vanderbilt roads, the Pennsylvania system, the Morgan roads, the Gould roads, Moore's roads, the Hill's roads and the Harriman Lines. [44]

The expansion and consolidation of the railroad companies required a massive amount of long-term capital for the extensive construction, the purchase of cars and other equipment, and the acquisition of securities and properties of other railroad companies. To meet these huge long-term financial needs, railroad companies relied on securities.

Among them, bonds were the primary financial instrument. While promoters and initial investors who lived along the lines preferred to own stocks to maintain their control over management, the Eastern and European investors preferred bonds. They believed that bonds would be safer and provide more regular income than stock because interest 
payment, unlike dividends, was obligatory. In fact, the proportion of bonds to capital stock shifted from 5:7 to 7:3 between 1855 and 1914. [45]

Compared with bonds and even common stock, preferred stock was much less important for railroad finance. As second-class stock, it had been used only to finance emergency funds and to supplement common stock during the construction periods.[46] After railroad competition intensified, preferred stock was mainly used for reorganization, under which dividends were set low without the need to make it attractive to investors. As Arthur S. Dewing argues, dividend rate of railroad preferred stock seldom exceeded 4 per cent, and its average was much lower than that of industrials and public utilities. [47]

Most of the bonds railroad companies used were mortgage bonds. When they expanded, they used existing roads as collateral to finance additional construction, considering that mortgages could protect interests of bondholders. In fact, however, the mortgage was often worthless, as Augustus J. Veenendaal Jr. argues, because the value of mortgage depended on operation and earning power of the company. In particular, "before the roads have actually built," "when traffic was too low," or "when competition forced the road ruinously low rates," the collateral was of no value. Also, overuse of mortgages ruined the security of bonds. Railroad companies adopted open mortgages to finance the huge demand for capital, but the second, third, and even fourth mortgage bonds were not well secured.[48]

Given these risks and limitations on mortgage bonds, railroad companies had to issue various other kinds of bonds to meet their financial needs. For example, they used debentures, a form of debt not secured "by any direct or indirect pledge of property."[49] 
These were issued either when the railroad company could not afford to use collateral or when its financial credit was high enough to sell this form of unsecured debt. Second, collateral trust bonds were secured by "a lien on securities deposited with a trustee as collateral."[50] It was useful for consolidation. "The acquisition of the stock of one railroad by another" was done "through the issue of its own bonds secured by the acquired stock as collateral.'[51] Another instrument, income bonds paid interest, only when the company had profits. Convertible bonds were securities exchangeable for capital stock after the business was going well. The merits to use convertible bonds were their salability because of the promise of regular payment of interest and the reduction of fixed-interest charge after the success in business. [52] Lastly, equipment trust bonds were used to purchase new equipments. These were secured by "a direct lien on a specific lot of rolling stock. [53]

Huge amounts of these railroad securities had been marketed in foreign countries especially after the railroad crisis in the 1870s. Although foreign investment in U.S. railroads did not increase constantly, it was an important financial source. According to Mira Wilkins, in 1914, 20 to 30 per cent of the nominal value of U. S railroad securities was sold in foreign countries including Britain, Germany, Holland, France, Canada, and other nations.[54]

When railroad companies issued these securities, they mostly relied on investment bankers. One of the most renowned investment bankers were the Morgans, who made their reputations as railroad financiers in the late 1870s when they dealt with Vanderbilt's sale of stock of New York Central Railroad. Jewish investment bankers such as Kuhn, 
Loeb \& Co., Speyer \& Co., and J. W. Seligman \& Co. also came to participate in railroad finance in the early twentieth century.

A significant role of investment bankers was mediation between investors and companies. To protect investors, investment bankers investigated the safety of the securities they offered. Those securities should be "economically justifiable" [55] because dealing with speculative securities would harm investors' confidence. Even after distributing the securities, in order for investors to escape a loss, investment bankers interfered with management of the client companies as directors when these companies were in financial difficulties. As J. Bradford De Long argues, their representation upon the railroad board was advantageous because it warranted that "the firm was managed by capable and energetic executives."[56] In fact, institutional investors such as insurance companies required bankers' representation as a condition of purchase of securities.[57] Thus, as Richard Sylla and George David Smith argue, owner's power over management was replaced by control of financiers who did not necessarily own shares of the company. In other words, personal capitalism was transformed into "financial capitalism." [58]

\subsubsection{Financing Reorganization}

The number of railroad companies that succeeded in the geographic expansion of their lines and made considerable profits was few. Most of the railroad companies rather faced financial problems especially after the depression of 1893. According to Arthur Stone Dewing, an observer of these years, "upwards of 40 per cent of the railway mileage of the country passed into receivers' hands" at that time. [59] Railroad companies tended to extend their lines against each other, which resulted in overexpansion. The overexpansion led not only to a decreasing rate of return, but also to the excessive use of 
funded debt, which in turn meant the need for regular income to serve the debt. When the earnings could not meet interest payments, the companies, facing increasing floating debts, had to cut the expenditures for maintenance. In the end, these companies, unable to pay off their fixed charges, needed to be reorganized.

Reorganization aimed at the reduction of the fixed charges toward railroad companies and at the provision of ample new funds to pay "the accumulated debt," "the improvement of the roads", and "the expenses of reorganization." [60] In general, to reduce fixed charges, general first mortgage bonds were replaced by new mortgage bonds with lower interest rates. Also, "all the bonds junior to these first mortgage bonds" were "refunded into contingent charge security" such as preferred stock. Meanwhile, new funds were obtained mainly from three sources. First, funds were collected by assessment charged on the shareholders of the company. Shareholders had two options; they paid the assessments to keep their stock or gave up the ownership without paying it. The second financial source was the sale of newly issued bonds. Since it was not easy to sell the securities of the railroad company during its reorganization, the syndicate that dealt in the reorganization often subscribed a large block of bonds. [61] Lastly, receivers could collect funds through the issuance of receivers' certificate. Due to the difficulty in securing enough money to reconstruct impoverished railroads, the court permitted them to borrow funds "on the credit of the whole estate" of the railroads. [62]

Investment bankers played a central role in railroad reorganization. As financiers, they decided the terms and conditions of newly issued securities of the railroad company. They also set up a voting trust to obtain the power to represent the majority of stockholders. [63] In addition, they provided newly reorganized companies with funds by 
paying the assessments in place of defaulting security holders and by purchasing a block of newly issued securities of the new corporations as mentioned above. [64]

Investment bankers' involvement in railroad reconstruction is not only explained by their economic interests. While Edward G. Campbell attributes the involvement of investment bankers in railroad reorganization to sizeable profits they could make through their financial activity, others contended a sense of honor and responsibility of investment bankers as financiers. [65] For example, John Moody explained that J. P. Morgan could not stand that railroad securities they dealt in became "a worthless paper before the eyes of the world." [66] Ron Chernow also argued that J.P Morgan reorganized railroad companies in receivership, following gentlemen's agreement, when English investors asked him protection of their railroad securities.[67]

\subsubsection{The Decline of the Railroad Industry before World War I}

Although the scale of railroad companies expanded, the industry came to show the signs of a decline right before World War I. In fact, the industry had many problems. Scholars are skeptic of the role of investment bankers in railroad finance. Although, as seen in the case of Northern Securities Company, investment bankers often contributed to the prevention of excessive competition and the provision of harmony in the industry, Campbell accused investment bankers of the stagnation of the industry.[68] He stated that reorganization led by investment bankers brought stock watering; a huge amount of common and preferred stock was distributed to existing stockholders and bond holders to compensate for their financial sacrifice during the reorganization. The capitalization of floating debt through reorganization was, he argues, another problem in the industry. To secure new funds for reorganization, the newly issued bonds were sold to a syndicate, 
which increased fixed charges for the railroad companies. Furthermore, he continues that "the cost of receivership and reorganization proceeding" hampered sound finance of the industry. "The salaries of receivers, legal expenses," and syndicate fees, all were so expensive that the companies were forced to sell new securities. [69]

On the other hand, Albro Martin attributed the problem of the industry to the failure of the Interstate Commerce Commission to allow increases in rates. He argues that the Hepburn Act of 1906, which granted the ICC the authority to set the maximum rate, reduced earnings of railroad companies. At the same time the shock of 1907 led to long economic recession, and the rising costs of materials, labor, and capital all caused financial difficulty. As a result, the railroads turned to short-term bank-loans, and weaker lines often went into bankruptcy by failing to refund promissory notes. [70]

Another problem was caused by the way of expansion of the railroad, that is, the acquisition of stocks of constituent companies by the holding company. The acquisition was often financed by collateral trust bonds. When the earnings of the acquired companies could not pay dividends enough to cover the interest on the collateral trust bonds, the parent company was burdened with unprofitable acquisition. [71] More important, the legality of the holding company, in particular the pure holding company, was dubious. In 1904, a pure holding company, the Northern Securities Company, which held the shares of the Great Northern and the Northern Pacific, was dissolved due to the violation of the Sherman Anti-trust Act.

When the railroad industry faced these problems, the key financiers of the industry, investment bankers, were also challenged. In spite of the significant contribution of investment bankers in railroad finance, the government, skeptical of the 
concentrated financial power, began to regulate and suppress investment banking. In 1905, the Armstrong investigation looked into the close tie of life insurance companies and investment bankers. As a result of this investigation, life insurance companies as clients of investment bankers were prohibited from underwriting securities. [72] In 1911, the Supreme Court decision on the dissolution of Standard Oil and American Tobacco retarded mergers of railroad companies, in which investment bankers had been actively involved. In 1912, the Pujo investigation revealed a high degree of financial concentration in New York City and the absence of any control of it. This investigation led to the Clayton Antitrust Act of 1914. The Act forbade mergers and acquisitions where competition was substantially harmed and "the interlocking directorates of banks and trust companies.'[73] Also, the Federal Trade Commission Act of 1914 prohibited the

"unfair methods of competition," which could include large system-building strategies of railroads. In addition, the Federal Reserve Act of 1913 built a federal banking system. The twelve federal banks came to check the concentration of financial power in the Northeast.[74] Although investment bankers' contribution in railroad finance did not deteriorate greatly before World War I, the changing business environment gradually limited their role after the war.

\subsubsection{Railroad Finance from World War I to 1930}

World War I was a watershed of corporate financial practices in the railroad industry. When United States joined the war in 1917, railroad companies were placed under federal control due to war emergency. Until the railroad companies were returned to previous owners in 1920, railroad operations were controlled and supervised by the Railroad Administration of the United States. The impact of the war on the American 
economy and business environments affected railroad corporate financial practices in the post-war period.

First of all, the overexpansion of the business under the federal control had many railroad companies fall into debt in the early 1920s. Meeting the increasing war demand for the transportation, government administrators extended lines, improved facilities and added more locomotives and cars. To finance the expansion of business, railroads received loans from the government and issued a huge amount of securities repeatedly under the approval of the government. [75] In spite of the huge investment in the industry, however, railroad facilities and equipment was not well-maintained. The Railroad Administration failed to operate the industry properly due to its inexperience in railroad management. [76] After the war, therefore, railroad companies needed to make huge investments for improvement, while paying off war-time debt.

Another impact of the war was the change of anti-monopoly policy. The government overturned its anti-monopoly policy toward the railroads after the experience of federalization. To "compensate their owners" and to achieve "profitable and efficient operation in post-war years," the Transportation Act of 1920 was passed. The Act encouraged consolidation. [77] It attempted to consolidate railroads into a limited number of systems and allowed them to acquire properties of other railroads according to a consolidation plan devised by the Interstate Commerce Commission. Although consolidation was not achieved as the government had hoped, railroad companies were allowed to combine voluntarily with the governmental approval. [78]

These financial needs in improvements and the purchase of securities of railroad companies were mainly financed by internal funds. In the hearings before the Temporary 
National Economic Committee in 1939, John W. Barriger, who was associated with the Pennsylvania Railroad and many other railroad companies, testified that "the industry's own revenues, especially, funds derived from the depreciation charges" had been the principal financial source. Between 1920 and 1937, total depreciation charges of the Class I railroads, that is "the railroads with a gross revenue in excess of $\$ 1,000,000$, amounted to $\$ 3.6$ billion. [79] On the other hand, net capital secured from the sale of securities marked only $\$ 1.9$ billion, of which the funds raised through the sale of funded debt was $\$ 1.6$ billion and stock finance was $\$ 0.3$ billion. [80] In 1909, the Corporate Tax Act had allowed the companies to deduct depreciation from taxable income. [81]

The use of internal funds in the industry during the 1920s was explained in part by the difficulty in selling securities at that time. After World War I, railroad companies were not able to raise sufficient funds in the capital markets. The market value of railroad securities decreased from $\$ 20$ billion before the war to $\$ 12$ billion after. [82] Also, intensified competition for capital among the industries made it difficult for railroad companies to raise funds in the markets. In the 1920s, public utilities prospered through holding companies, and many manufacturing companies grew rapidly. Compared with public utility and industrial companies, the growth of railroads was slow. From 1919 to 1928 gross assets of 44 railroad companies grew by 2.4 per cent annually. On the other hand, those of 71 industrial companies grew by 5.2 per cent and those of 35 public utility companies by 12.3 per cent. [83] In addition, the government intervention in security issues hampered the use of securities. The Transportation Act of 1920 gave the Interstate Commerce Commission "blanket powers over the issuance of new securities." To approve new issues, the ICC determined that the issue is "for a necessary purpose, 
compatible with the public interest," and that "the proposed issue is reasonably necessary and appropriate for such purpose." The ICC even intervened in the amount and the price of issues, interest and dividend, profits of underwriters, and the relationship between the companies and certain bankers. [84]

The major railroad companies were profitable enough to accumulate internal funds; the rate problem before the war faded away during war emergency and the companies were able to secure return under the Transportation Act. When the government had controlled railroads during World War I, it realized that rates should be high enough to "maintain the credit of the roads and to enable them to perform efficiently their public functions under the present unusual and extraordinary condition."'[85] Facing war emergency, the ICC had approved the rate increase during the war. After the war ended, the ICC again granted the rate increase to "yield railroads a fair return upon the value of their properties used for transportation purposes" under the Transportation Act. [86] At that time, the rate increase was 20 per cent on passenger traffic and 25 to 35 per cent on freight.[87] Although the definition of a "fair return" was still controversial, the trend toward rate increase improved financial condition of railroad companies.

Another financial method for expansion of the railroads in particular in the late 1920s was the use of pure holding companies. Consolidation through the use of stock acquisition had been quite common practices in the industry since the late nineteenth century, but after the Transportation Act of 1920 was passed, railroad companies were required to obtain the authorization of the ICC for consolidaton. The formation of pure holding companies, however, made it possible to evade federal control on the railroad consolidation. For example, O.P and M.J Sweringen had used the device of pure holding 
company to build up their vast railroad system since 1916. By exchanging collateral stock of holding companies and stock of constituent companies, they pyramided holding companies with "a mere shoe-string investment of their own capital".[88] In 1929, finally, the Alleghany Corporation as the top pure holding company owned all the stock already held by the Van Sweringens in various railroads. [89]

As the use of internal funds increased, the close ties between investment bankers and railroad companies gradually loosened. In fact, traditional financial activity of longestablished banking houses was challenged by the newly emerging commercial banks. In the stock market boom of the 1920s, new bankers were eager to deal in stocks. [90] After the crash of the stock market in 1929, however, public confidence in the investment bankers was totally collapsed.’[91]

Thus, before 1930, railroad companies did not use equity finance, but bonds and internal funds. Before World War I, they mostly relied on bond issues through the conduit of investment bankers. After the war, on the other hand, they mostly used retained earnings, especially depreciation accruals, and to a lesser extent, bond issues. These financial features do not always fit to all railroad companies, however. In fact, the Pennsylvania Railroad Company, one of the biggest railroad companies in the United States, was quite different than most of the other railroads.

\subsubsection{The Pennsylvania Railroad Company}

\subsubsection{Corporate Finance before World War I}

The Pennsylvania Railroad was incorporated in 1846. The original line was 249 miles between Harrisburg and Pittsburgh. The company completed the system, extending 
lines from Philadelphia to Pittsburgh in 1857. Pittsburgh was a hub of the railroad network. It was a "leading trade center", and developed "sizable industries" such as iron and glass manufacturing. More important it had an access to coal mines. At that time, it came to be one of the largest cities west of the Appalachian Mountains. [92] Not only an operating company, the Pennsylvania was a holding company that obtained control over other railroad companies through acquisitions of stock. The aggregate lengths of the lines in the operating companies accounted for 4,541 miles in the end of 1915. [93] The company was one of the biggest and most successful railroads in the United States.

In the Pennsylvania Railroad, gross assets increased from $\$ 151$ million in 1880 to $\$ 952$ million in 1914, of which long-term assets consistently accounted for between 80 to 90 per cent. Two major items in long-term assets were the expansion of business, including construction of roads, the purchase of equipment, and the investment in other properties on one hand, and acquisitions of securities on the other hand. In other words, the company grew both with additional construction and with consolidation. Most of the increasing financial needs for these purposes were met by long-term funds. The total amount of stock and funded debt rose from $\$ 131$ million in 1880 to $\$ 717$ million in 1914 along with the increasing financial demand. (Table 2)

One of the unique features of financial practices of the Pennsylvania Railroad was its heavy reliance on equity finance. The ratio of stock to gross assets from 1880 to 1914 was between 44 per cent and 60 per cent. Unlike other railroad companies, the amount of capital stock issued was more than that of bonds. The ratio of funded debt to capital stock declined from 0.9 in 1880 to 0.43 in 1914 . The decrease in the ratio was a general trend except the recession years of 1907 and 1908. [94] The company's newly issued stock was 
(in Million Dollars)

\begin{tabular}{|c|c|c|c|c|c|}
\hline & $\begin{array}{c}\mathrm{A} \\
\text { Gross Assets }\end{array}$ & $\begin{array}{c}\mathrm{B} \\
\text { Fixed Assets }\end{array}$ & $\mathrm{B} / \mathrm{A}$ & $\begin{array}{c}\mathrm{C} \\
\text { Securities }\end{array}$ & $\mathrm{C} / \mathrm{B}$ \\
\hline 1880 & 151.3 & 125.1 & $82.70 \%$ & 130.9 & $104.6 \%$ \\
\hline 1885 & 207.9 & 171.9 & $84.30 \%$ & 161.9 & $94.2 \%$ \\
\hline 1890 & 258.5 & 207.1 & $80.10 \%$ & 189.5 & $91.5 \%$ \\
\hline 1895 & 278.3 & 236.4 & $85 \%$ & 217.0 & $91.8 \%$ \\
\hline 1900 & 333.3 & 290.8 & $87.20 \%$ & 240.1 & $82.6 \%$ \\
\hline 1905 & 577.1 & 469.1 & $81.30 \%$ & 494.4 & $105.4 \%$ \\
\hline 1910 & 835.2 & 718.9 & $86.10 \%$ & 652.2 & $90.7 \%$ \\
\hline 1914 & 951.5 & 850.6 & $89.40 \%$ & 717.1 & $84.3 \%$ \\
\hline
\end{tabular}

Source: Annual Reports, The Pennsylvania Railroad Company, 1880-1914

Table 2: Long-Term Finance of the Pennsylvania Railroad Company

mostly sold without using the open market. From 1891 to 1914, capital stock increased by $\$ 376,183,650$, of which $\$ 307,081,600$ was subscribed by existing shareholders, $\$ 45,988,550$ was transferred from scrip dividends and convertible bonds, and $\$ 14$, 413,500 was exchanged in the process of acquisition. [95] The rest of the stock, $\$ 8,700,000$ only, was sold to the open market. [96] In other words, more than 97 per cent of the increase in stock was distributed without using stock exchanges, and the allocation of new stock to existing shareholders accounts for more than 80 per cent of the increase in stock.

The avoidance to use the open market for the sales of new stock was attributable to several factors. Investors' suspicion of stock might make it difficult to sell. Stock was regarded as speculative unlike bonds with liens. Also, the company might allocate new stock to existing shareholders in order to obtain their acceptance of new issues. Since the increase in the number of shareholders would decrease the receipt of dividends for each shareholder, shareholders might be opposed to authorize the increase in stock without 
subscription privilege of new stock. In addition, the company might aim to create loyal investors instead of speculators by offering such privilege to existing shareholders.

Although most of the newly issued stock was distributed to the existing shareholders, the stock ownership was not necessarily concentrated; since some of the shares were sold in the markets from one investor to others, the number of shareholders increased. From 1880 to 1914, along with the increase on stock outstanding, shareholders increased from 13,000 to 91,571. However, as Table 3 shows, the average number of shares per shareholder did not increase during the period despite the allocation of new stock to existing shareholders.

\begin{tabular}{|r|r|r|r|}
\hline Year & Shares & Shareholders & $\begin{array}{r}\text { Shares per } \\
\text { shareholder }\end{array}$ \\
\hline 1880 & $1,377,404$ & 13,000 & 106.0 \\
\hline 1902 & $4,087,497$ & 28,408 & 143.9 \\
\hline 1903 & $5,928,365$ & 42,437 & 139.7 \\
\hline 1904 & $6,025,713$ & 42,230 & 142.7 \\
\hline 1905 & $6,050,947$ & 40,385 & 149.8 \\
\hline 1906 & $6,119,027$ & 40,153 & 152.4 \\
\hline 1907 & $6,291,833$ & 57,226 & 109.9 \\
\hline 1908 & $6,292,084$ & 58,273 & 108.0 \\
\hline 1909 & $8,021,296$ & 56,809 & 141.2 \\
\hline 1910 & $8,252,214$ & 65,283 & 126.4 \\
\hline 1911 & $9,077,557$ & 73,165 & 124.1 \\
\hline 1912 & $9,077,559$ & 75,155 & 120.8 \\
\hline 1913 & $9,984,677$ & 88,586 & 112.7 \\
\hline 1914 & $9,984,072$ & 91,571 & 109.0 \\
\hline
\end{tabular}

Source: Berle and Means, p55, Table VII , Annual Reports

Table 3: The Number of Shares and Shareholders of the Pennsylvania Railroad

The company's decision to use stock was in part explained by its reluctance to increase fixed charges borne from bond issues, since excessive bond issues had led many railroad companies to financial problems since the late nineteenth century. In spite of the huge financial needs, the high standing of the company enabled it to use common stock rather than bonds. In fact, it could stabilize dividends at a moderate level in order to 
obtain investors who preferred sound management of the company. In particular, after the recession in the early 1890s, the company maintained the dividend between 5 to 7 per cent. [97]

Meanwhile, preferred stock was not used in the company. As mentioned above, preferred stock was used for emergency finance and for reorganization in the railroad industry; the Pennsylvania Railroad did not have to use such securities. The strong confidence in the company enabled it to raise funds without using preferred stock.

Despite its heavier reliance on stock than on bonds, the value of bonds the company issued increased from $\$ 56,713,300$ in 1880 to $\$ 196,495,020$ in 1914 along with the growing financial demands. Among various bonds, general and consolidated mortgage bonds accounted for a large portion of funded debt. Although these bonds were "issued under blanket mortgages which come after all the preceding mortgages", [98] they were regarded as least risky; the company had only a small amount of first mortgage bonds, and the amount of the general and consolidated mortgage bonds were relatively stable due to the limitation set by mortgage. In fact, from 1880 to 1914 , mortgage bonds were issued three times. In 1893, the \$3,000,000 Consolidated Mortgage Bonds due 1943 were sold for the purposes of construction and equipment purchase. In 1895, the company's urgent needs of funds to redeem bonds and the favorable money market in London led to the issue of the $\$ 4,850,000$ Consolidated Sterling Bond due 1945. Finally, in 1908 , the company issued the $\$ 19,400,000$ Consolidated Mortgage Sterling Bonds and the $\$ 20,000,000$ Consolidated Dollar Bonds both due 1948 to meet current financial obligation. [99] The first two issues were negligible in terms of its amounts. The large issue of 1908 was the reaction against financial emergency during the recession. 
To supplement mortgage bonds, the company used other kinds of bonds. Collateral trust bond were introduced in 1883 to finance a part of improvement and construction; the 10,000,000 4 1/2 per cent Collateral Trust Loan due 1913 was secured by bonds of "branch and auxiliary lines representing a par value of $\$ 12,500,000 . "$ [100] The use of collateral trusts bonds, instead of the sale of bonds of auxiliary lines, was advantageous. Whereas bonds of auxiliary lines owned by the Pennsylvania Railroad bore interest at 5 to 7 per cent, interest payment for collateral trust bonds was 4 per cent only due to the confidence in the Pennsylvania Railroad. [101] The company also used various series of equipment trusts bond. This is a method to finance the purchase of new equipment at lower interest rate; it bore $3 \frac{1}{2}$ to 4 per cent. [102] Lastly, convertible bonds were sold twice between 1880 and 1914: the $\$ 50,000,0003 \frac{1}{1 / 2}$ per cent Convertible Bonds were issued in 1902 in order to meet expenditure for the equipment and the construction, and the $\$ 100,000,0003 \frac{1}{2} 2$ per cent Convertible Bonds in 1905 for the redemption of the Consolidated Mortgage Bonds. [103] After 1902, convertible bonds accounted for a large part of funded debt, which reflected the company's preference to equity finance.

A huge amount of these bonds were marketed in foreign countries. In fact, Pennsylvania Railroad had used foreign capital since the 1850s. According to Wilkins, in 1853 , "\$2.5 million of its $\$ 3$ million in bond outstanding" of the company was held in foreigners. [104] She also points out that British enterprises and French investors were also attracted by bonds of the company in the early twentieth century. [105]

In spite of the confidence of the public in the company, it often used investment bankers as underwriters to distribute its bonds. Although fees and commissions for 
underwriting business were not small, keeping a long-term relation with investment bankers was useful for the company. Investment bankers provided financial support in case of emergency, and more important, the company could avoid risk in the sale of bonds; underwriting syndicate of investment bankers received unsold bonds. [106]

In addition to stocks and bonds, the company also used retained earnings. During 1880 and 1914, the accumulated surplus and reserves increased from $\$ 9.7$ million to $\$ 133.7$ million. Accumulated depreciation increased from $\$ 6,327,159$ in 1910 to $\$ 18,897,398$ in 1914 . Figure shows the ratio of the sum of these internal funds to gross assets. [107]

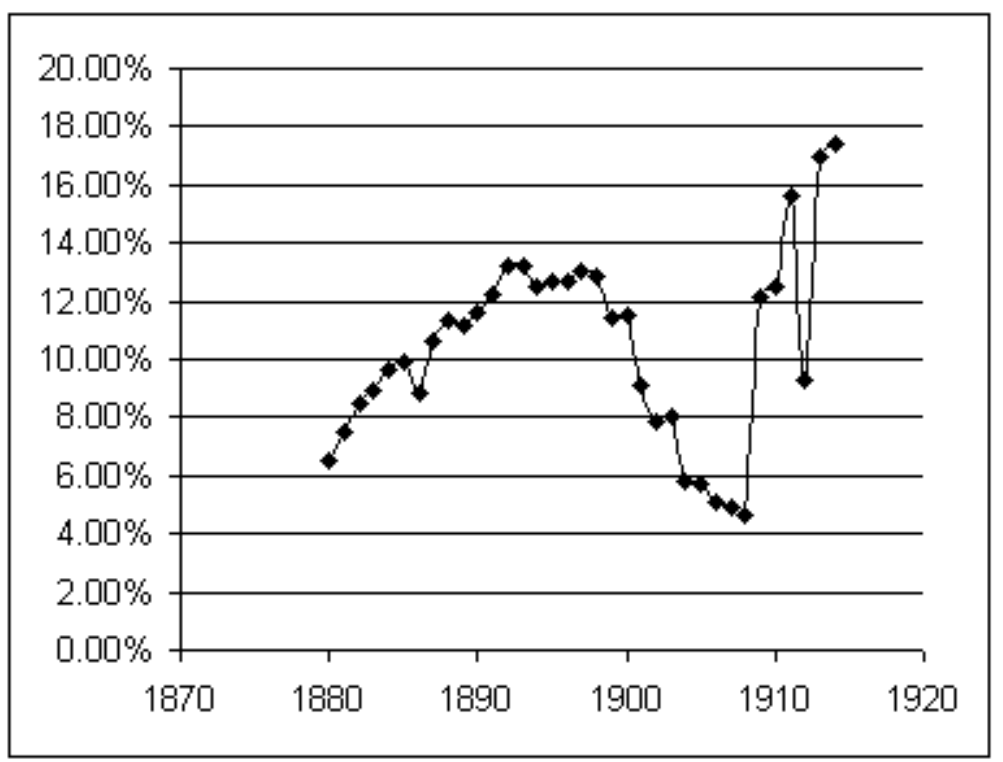

Source: Annual Reports

Figure 1: The Ratio of Accumulated Internal Funds to Gross Assets.

The ratio gradually increased in the late nineteenth century, but it rapidly plummeted in the early 1900 s due to new stock issues, the stagnation of the increase in retained earnings, and the economic recession of 1907. In 1910, when the company 
applied depreciation, it again rose to 12.1 per cent. In 1914 , it reached 17.0 per cent. Although the contribution of internal funds was not negligible, it is still smaller than the ratio of stock to gross assets and that of bonds, 52 per cent and 22 per cent in 1914 respectively.

\subsubsection{Corporate Finance during and after World War I}

During World War I, gross assets of the Pennsylvania Railroad Company continued to grow, although the rise of wage, fuels, other supplies, and taxes during the war reduced income.[108] During federal control from December 1917 to March 1920, the company invested in additions and improvements of properties in order to deal with the expanding demand for transportation for war purposes. At that time, in contrast, the increase in the investment in the securities of affiliated and other companies was sluggish. Despite the huge expenditure, however, the properties under federal control were under-maintained when they were returned to the previous owners after the war. The company claimed the loss of $\$ 400,000,000$ for the under maintenance of roads and structures. [109] Consequently, the company needed to make a huge investment for improvement. In addition, after the post-war recession, the company needed funds for mergers and acquisition. While the Transportation Act of 1920 limited the expansion of the company as a holding company until the middle of the 1920s, it was still able to engage in consolidation through acquisitions. After the revision of the Act in 1925, as a holding company, it began to increase the number of its subsidiaries once again. [110]

Unlike in the pre-war years, the role of stock in meeting these increasing financial needs gradually declined during and after the World War I. In fact, no new stock was issued from 1913 to 1927 . It was during the stock boom in the late 1920 s that the 
company issued new stock. [111] Instead of stock, the Pennsylvania increased bonds. Outstanding funded debt increased rapidly after 1914. The change of financial practices was led by President Samuel Rea. In 1914, he supported the use of bonds in future financing "because money could thus be obtained at a lower rate than the established dividend, and also because bond interest could be deducted from income before computing the new federal income tax." [112] To extend bond finance, he created a new mortgage amounting to $\$ 80,000,000$. The Board and then shareholders authorized the new mortgage bonds "to an amount not in excess at any time of the outstanding capital stock." [113] Thus, from 1914 to 1930, the company increased its reliance on mortgage bonds.

These bonds were salable abroad only with higher interest rate. While the interest rate of the best American railroads were 4.5 to 5 per cent before World War I, the Pennsylvania Railroad issued 7 per cent 10 year secured bonds in 1920.[114] Since American railroad securities lost their popularity, only a few major railroad companies that could afford the high interest could market their securities in foreign countries.

More important, the company began to use more internal funds than before. Of the increase in gross assets from 1914 to $1930,47.4$ per cent was attributed to the use of internal funds, 18.3 per cent to stock and minus 5.2 per cent to bonds. [115] This increase in the use of internal funds is also reflected on the ratio of internal funds to gross assets.

As Figure 2 shows, the ratio of internal funds to gross assets rapidly increased after World War I. Compared with the ratio of stock and bonds, internal funds was one of major financial sources in the company. (Table 4) 


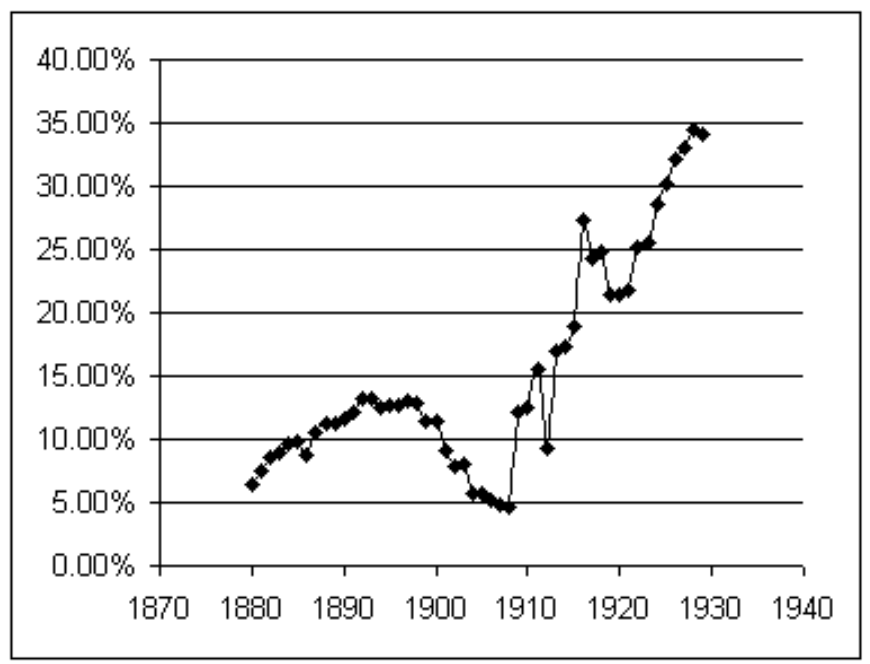

Source: Annual Reports

Figure 2: The Ratio of Internal Funds to Gross Assets of the Pennsylvania Railroad.

\begin{tabular}{|l|r|r|r|r|r|}
\hline & 1914 & 1917 & 1920 & 1925 & \multicolumn{1}{|c|}{1929} \\
\hline Stock/Gross Assets & $52 \%$ & $40 \%$ & $27 \%$ & $27 \%$ & $28 \%$ \\
\hline Bonds/Gross Assets & $22 \%$ & $24 \%$ & $21 \%$ & $33 \%$ & $27 \%$ \\
\hline Internal Funds/Gross Assets & $17 \%$ & $27.3 \%$ & $21.5 \%$ & $28.6 \%$ & $34.1 \%$ \\
\hline
\end{tabular}

Table 4: Long-Term Finance of the Pennsylvania Railroad after 1914

At the Pennsylvania Railroad, as Berle and Means argued, stock came to be widely distributed among the public. In part, due to its gigantic financial needs, the company required a huge number of shareholders. From 1914 to 1927, while the number of shares of stock outstanding was not changed, the number of shareholders increased from 91,571 to 143,249 . The average number of shares per shareholder decreased from 109 shares in 1914 to 70 shares in 1927 and 63 shares in 1930. [116] (Figure 3) The wide distribution of shares of the company seems to fit the idea of the separation of ownership and management. However, in the 1920s, other financial sources became more important 
than stock. The use of bonds increased to a same extent as stock, and more important, the company relied on internal funds more than any other financial sources. The company seemed to achieve a certain level of managerial autonomy based not only on the dispersion of stock to the public but also on self-finance in the late 1920s.

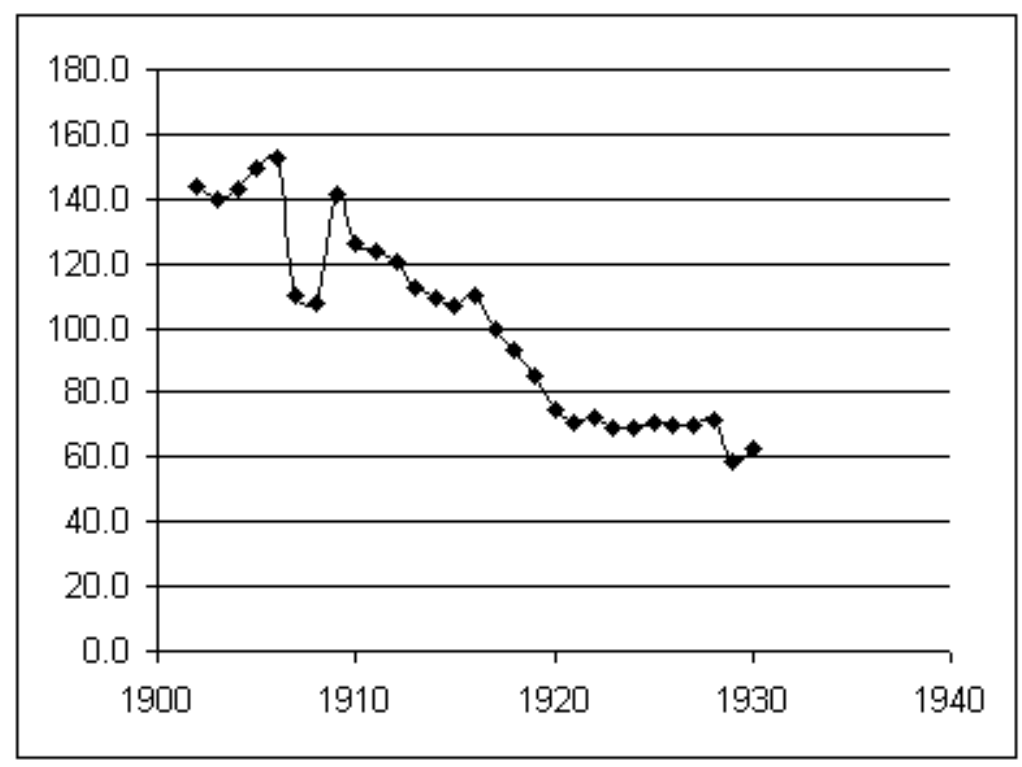

Source: Berle and Means p55, Table VII; Annual Reports, the Pennsylvania Railroad, 1902-1930)

Figure 3: The Number of Shares per shareholder in the Pennsylvania Railroad.

While the pattern of railroad finance is characterized as bond finance before World War I and the use of internal funds after, stock issues was a major financial source of the Pennsylvania throughout the time due to its high standing and the managers' reluctance to have fixed charges through bond issues. After World War I, the company came to use bonds and internal funds to a similar extent as stock. Its reliance on stock and wide distribution of stock seem to fit Berle and Means model, but the Pennsylvania, one of the biggest railroads, was an exception. 


\subsection{Public Utility Finance, 1870-1920}

\subsubsection{Corporate Finance before World War I}

According to Vincent P. Carosso, public utilities began to use the capital market from the late 1870s. [117] At that time, most of public utility issues were relatively small because public utilities were basically local businesses, whose securities were "salable only in their local market." [118] However, in twenty years, they expanded and improved their facilities to meet the increasing demand from the public. Especially, large companies organized holding companies to execute monopolistic control over the market. Although antimonopoly sentiments prevailed in the public, public utilities companies were allowed to create big business. The necessity of the expansion of utilities was later explained by Walter Lagerquist; considering the narrow market and huge amounts of fixed cost of public utilities companies, competition meant the "duplication of physical facilities," which would impose additional charges on the public. [119] To have the utility companies provide public service at proper rates, the privilege of monopoly should be given to them under the control by the government regulation. [120] This theory fit such industries as gas and electricity, where economies of scale exist.

To finance the establishment of huge facilities and the purchase of equipment, utility companies, in particular, gas and electric utilities relied on bonds rather than stock in the early years; the public was not confident in stock of newly emerging businesses. In fact, utilities stocks were rated as too speculative for individual investors as well as for organizational investors in the New York Stock Exchange. [121] Even through bonds, however, it was difficult for the companies to obtain sufficient capital. Since the demand for utility securities was not large enough to finance the business, utilities companies 
often exchanged their bonds for the equipment produced by manufacturing companies. Even if they could sell all the bonds issued, funds raised through bonds were still short because the amount of bonds they could issue was usually limited due to the adoption of closed-end mortgages. [122]

After 1900 the public utility companies could obtain funds through bond issues easier than before. Investors came to regard public utility bonds as safe because of stable demand, governmental protection from competition, reasonable returns fixed by public authority, and mortgage security based on heavy investment at that time.[123] Also, the use of convertible bonds, sinking funds, and depreciation provisions made utility bonds attractive. In addition, the adoption of open-end mortgage bonds helped increase the amount of bonds the companies could issue. [124]

As did railroads, public utility companies utilized various types of bonds in addition to mortgage bonds. They began to use collateral trust bonds during the economic recovery in 1898. [125] Especially, public utility holding companies in the 1880s realized money from a multitude of small bond issues by using the first mortgage bonds of the subsidiary companies as the security. [126] Refunded debt was also used extensively after 1898. Although those bonds in the railroad industry were primary used during reorganizations, public utilities used them for consolidations, mergers, and simplification of the financial structure.[127] In addition, the utility companies, especially larger ones, often issued debenture bonds after the Recession of 1907, facing urgent financial needs, although investors in public utilities had usually demanded a direct lien.

Dewing argued that ideally 50 per cent of public utility financing should be done by funded debt, with the rest divided equally between common and preferred stock. 
Although these per centages were different from industry to industry, there is no doubt that bonds in general played a major role in public utility financing. [128]

Though stock was less important than bonds in public utility finance, public utilities companies used stock, in particular preferred stock, more often than railroad companies did. While most of common stock of public utilities was absorbed by the manufacturing companies and holding companies due to the difficulty in marketing the shares of utility companies, preferred stock, which was regarded as "conservative speculation," was more readily absorbed by the public. Preferred shares carried high dividend, which was attractive to investors. In fact, in 1914 high-grade preferred stock usually yielded 6 to 7 per cent [129]

The increasing reliance on securities markets by public utility companies led investment bankers to become more involved in public utility finance in the 1890s, although financial relations between investment bankers and public utilities companies was not new. For example, as Carosso explains, the Drexel, Morgan \& Co. began to participate in public utilities finance from 1870s, but its commitment gradually increased. The Edison Electric Light Company was the first Drexel, Morgan had been interested in among the public utilities since the late 1870s. In the 1880s, Drexel, Morgan "held the company's deposit, and arranged loans, and managed some of its foreign business."[130] In 1889, it arranged the consolidation of Edison's properties and established the Edison General Electric Company. [131] As the size of the utilities companies expanded along with the increasing demand for public services, they needed more capital than before. At the time, investment bankers no longer treated most of public utilities companies as risky business; investment in the established utilities firms was regarded as safe and profitable. 
Especially, after railroad business declined during the panic of 1893, investment bankers' dealings in public utilities accelerated. One of the exceptions was the telephone industry. Cautious of its newness, J.P Morgan \& Co, as renamed from Drexel, Morgan, began to be involved in corporate finance of the American Telephone \& Telegraph Company after the turn of the century. [132]

As with the railroad industry, investment bankers dealt with bonds but not with stock of the public utility industry because of stock watering. Public utilities were often overcapitalized through the process of merger, amalgamation and sales of stock of holding companies. Thus, investment bankers' influence on the management of public utilities was based on their marketing of bonds. [133]

\subsubsection{Corporate Finance from World War I to 1930}

The growth of the public utilities was temporary hampered by World War I.

During the War, the lack of labor, materials, and capital drove up operating costs. Also, the increase in corporate taxes due to the war emergency hit the industry hard. In addition, the restriction on the use of lighting imposed by the United States Fuel Administration reduced revenues in the electric power and the gas industries. [134] The rising cost and taxes and the decrease in revenues forced the companies to issue an “undue proportion of bonds.”[135]

In the 1920 s, the public utility sector grew rapidly as the economy recovered. To meet their financial need, public utilities increased their bond issues. According to Eli Winston Clemens, capital required in the sector increased from $\$ 0.5$ billion in 1920 to 2.4 billion in 1930 . In the 1920 s, 69 to 87 per cent of the capital requirement was new capital for construction and the purchase of properties. Most of these funds were raised 
through securities, especially bonds. Although high interest rate in 1920 led companies to issue short-term notes rather than long-term bonds, bonds still accounted for 57.5 per cent to 71.4 per cent of all financing from 1921 to 1928 . In contrast, stock issues explained 12.2 per cent to 35.8 per cent of all financing. Only in 1929 did stock overtake bonds; bonds accounted for 37.7 per cent of all financing and stock 58.6 per cent. On the other hand, unlike railroads, internal funds were still not an important financial source in public utilities. It was only during the 1930s that utility companies came to rely on internal funds. At that time, public utilities faced the difficulty in marketing bonds bearing low yields. Also, the slow growth of the public utilities due to industrial maturity in the 1930s led to the different financial method from that of the periods of expansion. [136]

One significant features of post World War I finance of public utilities was the importance of the holding company. In the 1920s many small utility companies, especially electric light and power companies, integrated into several holding companies or parent operating companies. According to Clemens, 71 companies were incorporated as holding companies by 1930, of which 46 appeared between 1920 and 1929. [137]

Under the holding company system, an operating company obtained funds from the holding company, either in exchange for the operating company's securities or as a loan. The holding company raised the money needed by the sale of its bonds and stock to the general public, using the stock and bonds of its operating companies as security. [138] According to Clemens, in the early 1920s, bonds issued by holding companies were only 10 per cent of public utility debt, but in 1928 more than half of public utilities' funded debt was holding company bonds. [139] 
Another feature of finance in public utilities after World War I was customer ownership, that is, the direct sale of stock to customers. The introduction of customer ownership was associated with the war experience of the utility companies; under the increasing demand for capital, soaring costs, and unfavorable conditions of money market, utility companies used sales of stock to customers to obtain scarce capital. In the 1920s, customer ownership became an increasingly important financial method. In 1923, approximately $\$ 250,000,000$ of stocks was sold by the electric utility industry through customer ownership. The method was widely used not only by the electric utility industry but also by the gas and the telephone industries. [140]

The policy of direct sale was advantageous for the public utility companies in any ways. First of all, the use of utility company employees to sell stock to the public was cheaper than hiring professional salespeople. The former cost $\$ 3$ to $\$ 5$ per share, while the latter $\$ 6$ to $\$ 8$. Second, users of service were familiar with the utility company and thus not afraid of holding its shares. Third, the employees could reach small local investors who were "more likely to buy from them than from professional stock salesman."[141] Fourth, the managers of the utility companies could reduce the power of investment bankers, who had in earlier years played a major role in distributing public utility stock. Finally, public utility companies improved public relations through customer ownership. By emphasizing public ownership, the companies attempted to justify their monopoly positions. They also held balance the rate reduction and dividend payments to match public interest and shareholders' interest. [142]

Although equity finance was not a major financial source in public utilities, stock of public utilities was more widely distributed than that of railroads. On one hand, 
railroads mainly distributed stock to stockholders. This is attributable to the fact that railroads served local businesses and people; local interests were eager to maintain their control over management of the railroad companies, unlike outside investors. On the other hand, public utilities distributed stock through the market and later even allocated it to the customers of the companies. This wider distribution of stock of utility companies in the public was explained by the public nature of utility companies, which served a much broader section of the public than railroads.

Although these corporate financial practices were considered to be typical in the public utility sector, actual practices were different from firm to firm within the sector. In particular, the telephone industry shows distinctive features of corporate financial practices due to its newness, nature of business, and monopolistic industrial structure. The industry was controlled by a huge holding and operating company, the American Telephone and Telegraph Company.

\subsubsection{The American Telephone \& Telegraph Company}

\subsubsection{Corporate Finance before World War I}

The telephone industry was a latecomer in the public utilities sector. When Alexander Graham Bell patented his invention in 1876, the industry attracted few investors and was not treated as a public utility. With only a small amount of capital, the business started as a partnership, the Bell Telephone Association. However, along with the increasing demand for telephone service, the business was incorporated and greatly expanded its size in next decades through mergers and acquisitions. In 1878, it formed

the New England Telephone Company and the Bell Telephone Company in Massachusetts, with capitalization of $\$ 200,000$ and $\$ 450,000$ respectively. The two 
companies were integrated into the National Bell Telephone Company with capitalization of $\$ 8,500,000$ in the next year. In 1880 , in turn, the National Bell became the American Bell Telephone Company with a capitalization of $\$ 100,000,000$. Finally, the company was taken over by its subsidiary, the American Telephone and Telegraph Company, which had been established as a long-distance company in New York in 1885. Facing the interference of the Massachusetts legislature in the increase in capital and stock holding, the officials of the American Bell decided in 1900 to transfer the function of the parent company to the subsidiary in New York. As a holding company as well as an operating company of long-distance lines, the A.T.\&T. rapidly grew before the World War I. [143]

This gigantic corporate entity was mostly accepted by the public and by the state and federal governments because, as the company insisted, the industry required "One system," "One Policy," "Universal Service" to provide better communication service.[144] According to Attorney-General George W. Wickersham, since "the value of a telephone service depends largely upon the facility of connecting every individual telephone user with any point, upon any telephone line," monopolistic industrial structure was accepted under "suitable supervision and control" by the government. Although in some states, the company could not avoid the allegation of monopoly, in general it successfully justified its existence by insisting on the nature of its communication service. [145]

To finance this big corporate entity demanded a huge amount of funds, especially long-term capital. According to annual reports of the company, fixed assets continued to increase from $\$ 9,992,861$ in 1881 through $\$ 93,750,292$ in 1900 to $\$ 595,041,161$ in 1913 , although in 1914 , it temporarily decreased to $\$ 552,996,796$ due to the reduction of 
advance to associated companies and the sale of their stocks. Especially, after the recession of 1907, the ratio of fixed assets to gross assets accounted for 82 per cent to 94 per cent. The huge capital requirement was mostly associated with the purchase of securities in other companies, which increased from $\$ 71,719,324$ in 1900 to $\$ 533,403,879$ in 1913 . Compared with this huge amount of fixed assets, construction cost was not a significant amount. The construction item appearing in the annual reports increased from $\$ 16,152,021$ in 1900 to $\$ 49,819,065$ in 1914 , but it accounts for only 10.8 to 22.7 per cent of the purchase of stock and bonds. (Table 5)

(in Dollar)

\begin{tabular}{|c|c|r|r|r|r|c|}
\hline Year & $\begin{array}{c}\text { A } \\
\text { Gross Assets }\end{array}$ & $\begin{array}{c}\text { B } \\
\text { Fixed Assets }\end{array}$ & $\begin{array}{c}\text { C } \\
\text { B/A }\end{array}$ & $\begin{array}{c}\text { D } \\
\text { Securities }\end{array}$ & $\begin{array}{c}\text { E } \\
\text { Construction }\end{array}$ & $\begin{array}{c}F \\
\text { E/D }\end{array}$ \\
\hline 1880 & $10,162,113$ & $9,992,861$ & $98.3 \%$ & $1,837,500$ & N/A & N/A \\
\hline 1890 & $36,636,336$ & $34,404,188$ & $93.9 \%$ & $32,740,580$ & N/A & N/A \\
\hline 1900 & $122,234,983$ & $93,750,292$ & $76.7 \%$ & $71,719,324$ & $16,152,021$ & $22.5 \%$ \\
\hline 1901 & $145,198,394$ & $110,235,129$ & $75.9 \%$ & $84,339,912$ & $19,116,209$ & $22.7 \%$ \\
\hline 1902 & $190,414,904$ & $145,628,377$ & $76.5 \%$ & $114,864,799$ & $22,486,192$ & $19.6 \%$ \\
\hline 1903 & $224,381,524$ & $166,332,194$ & $74.1 \%$ & $130,678,449$ & $26,876,806$ & $20.6 \%$ \\
\hline 1904 & $273,819,672$ & $179,108,590$ & $65.4 \%$ & $138,684,248$ & $30,889,710$ & $22.3 \%$ \\
\hline 1905 & $296,302,202$ & $207,334,056$ & $70.0 \%$ & $161,554,277$ & $34,694,764$ & $21.5 \%$ \\
\hline 1906 & $353,801,015$ & $235,846,930$ & $66.7 \%$ & $182,357,238$ & $40,336,776$ & $22.1 \%$ \\
\hline 1907 & $396,357,982$ & $328,689,104$ & $82.9 \%$ & $273,404,797$ & $41,621,175$ & $15.2 \%$ \\
\hline 1908 & $440,932,822$ & $363,450,550$ & $82.4 \%$ & $309,018,695$ & $42,650,990$ & $13.8 \%$ \\
\hline 1909 & $494,089,807$ & $417,454,250$ & $84.5 \%$ & $310,475,309$ & $44,295,660$ & $14.3 \%$ \\
\hline 1910 & $507,515,377$ & $453,414,925$ & $89.3 \%$ & $356,950,838$ & $45,948,392$ & $12.9 \%$ \\
\hline 1911 & $565,523,189$ & $522,964,593$ & $92.5 \%$ & $407,548,400$ & $48,155,893$ & $11.8 \%$ \\
\hline 1912 & $606,762,089$ & $570,650,668$ & $94.0 \%$ & $447,598,318$ & $48,635,006$ & $10.9 \%$ \\
\hline 1913 & $655,956,307$ & $595,041,161$ & $90.7 \%$ & $454,888,264$ & $49,269,173$ & $10.8 \%$ \\
\hline 1914 & $628,616,993$ & $552,996,796$ & $88.0 \%$ & $435,727,228$ & $49,819,065$ & $11.4 \%$ \\
\hline
\end{tabular}
Source: Annual Reports, 1880-1914

Table 5: Assets of the American Telephone \& Telegraph Company

The significance of expenditure for stock purchase reflected the A. T. \& T's management policy; the company should make the best use of existing exchanges and facilities belonging to its associated companies in order to “minimize A. T. \& T's capital 
expenditures and to maximize its coverage of the national network." [146] This policy was attributed to the nature of the telephone business. According to economic theory, companies requiring huge fixed investment benefit from economies of scale; the more they produce goods and services, the more unit costs decrease and profits per unit increase. However, this was not the case with the A.T.\& T. The extension of lines and the construction of new facilities in local areas increased costs more than profits per unit. Unable to finance all the costs for geographical expansion, the newly established operating companies were financed by local entrepreneurs. To maintain controlling power over the telephone industry, the A. T. \& T. acquired substantial amounts of stock of these operating companies. [147]

To meet the financial needs, A. T. \& T. heavily relied on common stock issue, unlike other utility companies. Stock outstanding overwhelmed bonds throughout the years except in 1908. From 1901 to 1914, the ratio of stock to gross assets was between 41 per cent and 72.9 per cent, and that of bonds was between 8.2 per cent and 42.9 per cent. The company did not use any preferred stock. Thus, Dewing's 1914 statement, that 50 per cent of public utility financing was met by funded debt and 25 per cent by preferred stock, was not applicable to this company. (Table 6)

Stehman attributed the company's reliance on common stock to several factors. First of all, the company did not issue mortgage bonds because the assets of a telephone company were not suitable as mortgages. The assets of the company, Stehman explains, were "of little value except for the business of telephone." Also, public perceptions of the telephone industry made it difficult to sell other securities than stock. Since telephone business was not regarded as a public utility at first, the public was not eager to invest in 
risky industrial bonds. In fact, telephone companies were officially regarded as public utilities in the early twentieth century for the first time. As public utilities, they began to be regulated by City and State Commissions from 1907, and the functions of the Interstate Commerce Commission were extended to cover telephones from 1910. [148] Finally, he argues that common stock was "just as advantageous so long as no preferred stock was outstanding." [149] In other words, although preferred stock was attractive for investors because of its preference in dividends to common stock, common stock could be attractive enough unless preferred stock is issued.

(in Dollar)

\begin{tabular}{|c|c|c|c|c|c|}
\hline & $\begin{array}{c}\text { A } \\
\text { Gross Assets }\end{array}$ & $\begin{array}{c}\text { B } \\
\text { Stock }\end{array}$ & $\begin{array}{c}\text { C } \\
\text { B/A }\end{array}$ & $\begin{array}{c}\text { D } \\
\text { Bonds }\end{array}$ & $\begin{array}{c}\mathrm{E} \\
\text { D/A }\end{array}$ \\
\hline 1900 & $122,234,983$ & $89,100,500$ & $72.9 \%$ & $10,006,000$ & $8.2 \%$ \\
\hline 1901 & $145,198,394$ & $104,650,600$ & $72.1 \%$ & $15,004,500$ & $10.3 \%$ \\
\hline 1902 & $190,414,904$ & $114,946,500$ & $60.4 \%$ & $28,000,000$ & $14.7 \%$ \\
\hline 1903 & $224,381,524$ & $154,179,300$ & $68.7 \%$ & $28,000,000$ & $12.5 \%$ \\
\hline 1904 & $273,819,672$ & $158,661,800$ & $57.9 \%$ & $53,000,000$ & $19.4 \%$ \\
\hline 1905 & $296,302,202$ & $158,661,800$ & $53.5 \%$ & $108,000,000$ & $36.4 \%$ \\
\hline 1906 & $353,801,015$ & $158,661,800$ & $44.8 \%$ & $108,000,000$ & $30.5 \%$ \\
\hline 1907 & $396,357,982$ & $179,595,255$ & $45.3 \%$ & $153,000,000$ & $38.6 \%$ \\
\hline 1908 & $440,932,822$ & $180,587,000$ & $41.0 \%$ & $189,048,000$ & $42.9 \%$ \\
\hline 1909 & $494,089,807$ & $256,475,300$ & $51.9 \%$ & $101,140,000$ & $20.5 \%$ \\
\hline 1910 & $507,515,377$ & $263,335,600$ & $51.9 \%$ & $116,941,000$ & $23.0 \%$ \\
\hline 1911 & $565,523,189$ & $318,427,500$ & $56.3 \%$ & $98,459,000$ & $17.4 \%$ \\
\hline 1912 & $606,762,089$ & $334,805,700$ & $55.2 \%$ & $105,002,000$ & $17.3 \%$ \\
\hline 1913 & $655,956,307$ & $344,616,300$ & $52.5 \%$ & $159,591,000$ & $24.3 \%$ \\
\hline 1914 & $628,616,993$ & $344,681,900$ & $54.8 \%$ & $159,505,000$ & $25.4 \%$ \\
\hline
\end{tabular}

Source: Annual Reports, The American Telephone \& Telegraph Company, 1900-1914

Table 6: Long-Term Finance in the American Telephone \& Telegraph Company

Similar to the Pennsylvania Railroad, a significant portion of A. T. \& T.'s stock was subscribed by existing shareholders. In 1899, A. T. \& T.'s outstanding capitalization was $\$ 83,882,980$, of which $\$ 51,772,600$ was issued for the existing stockholders of the 
American Bell Company. [150] After the formation of the A.T. \& T. as the parent company, most of the stock was subscribed by existing shareholders; the stock issues of $\$ 21,000,000$ in 1902 and of $\$ 55,000,000$ in 1911 were all subscribed by existing shareholders. Only in 1907 in the middle of recession, shareholders were not able to finance the purchase of newly offered stock; they subscribed to 9,486 shares out of 19,252 shares. The rest of stock was widely offered to the general public and even in London.[151]

Although newly issued stock was usually allocated to existing shareholders, the number of shareholders increased not only through the sale of the stock by existing shareholders to other investors but also the issues of convertible bonds. The company issued \$100,000,000 4 per cent Convertible Bonds in 1906 and \$50,000,000 4 per cent Convertible Bonds in 1908. These bonds were distributed through the syndicate comprising J.P Morgan \& Co., and Kidder, Peabody \& Co., Kuhn, Loeb \& Co. in the United States and Baring Brothers \& Co. in London. [152] In addition, since the New York Stock Exchange listed the full amount of these bonds, the public had access to the purchase of the bonds. [153] The widely distributed bonds were convertible to stock after March 1909; in the end of the year, $\$ 101,861,000$ convertible bonds was converted into stock, and between 1910 to 1914, additional \$6.7 million bonds were converted. [154] In fact, the approximate number of shareholders increased from 12,000 in 1900 to 60,000 in 1914 , and the amount of capital stock per shareholders reduced from $\$ 10,465$ in 1901 to $\$ 5,745$ in $1914 .[155]$

To facilitate the sale of the stock and the conversion of convertible bonds, as Horace Coon explains, the company provided "continuous, stable and substantial" 
dividends. [156] From 1900 to 1905, the company paid \$7.5 per share, and from 1906 to $1921 \$ 8$ per share regularly. The company made profits enough not only to pay these dividends but also to increase its retained earnings. As a result, it could maintain stock price as high as $\$ 120$ per share in the New York Stock Exchange. [157]

Bonds were less important than stock in the telephone company, as indicated in the ratio to gross assets, but they played a significant role when the company expanded in the early 1900s. The amount of bonds outstanding rose from $\$ 10,006,000$ in 1900 to $\$ 189,048,000$ in 1908. [158] As Figure 4 shows, the increase in bonds outstanding overwhelmed that of stock between 1904 and 1908. According to Robert W. Garnet, since A. T. \& T.'s financial support for the associated companies amplified the demand for new funds, debt financing in addition to stock issues were unavoidable. He also attributes the move into debt finance to the policy of President, Frederick P. Fish, who headed the company from 1901 to 1907 . Fish regarded financing by issuing of more stock as unrealistic in the phase of the expansion of telephone. He believed that increasing costs for expansion could not be financed without bond issues. Under his administration, the company issued bonds amounting to $\$ 188$ million. [159]

This change of financial practice was a surprise to the public. In 1905, after the issue of collateral trust bonds of $\$ 25,000,000$, it was predicted that "next capital issue will probably be stock instead of bonds."[ 160$]$ However, the A.T.\& T. decided to issue $\$ 150,000,000$ in convertible bonds, which were regarded by investors as a change of financial "principles" of the company. The stockholders of the A.T.\&T. were discontented with this move. The bond issue would mean "a large increase of fixed charge ahead of the stock.”[161] 


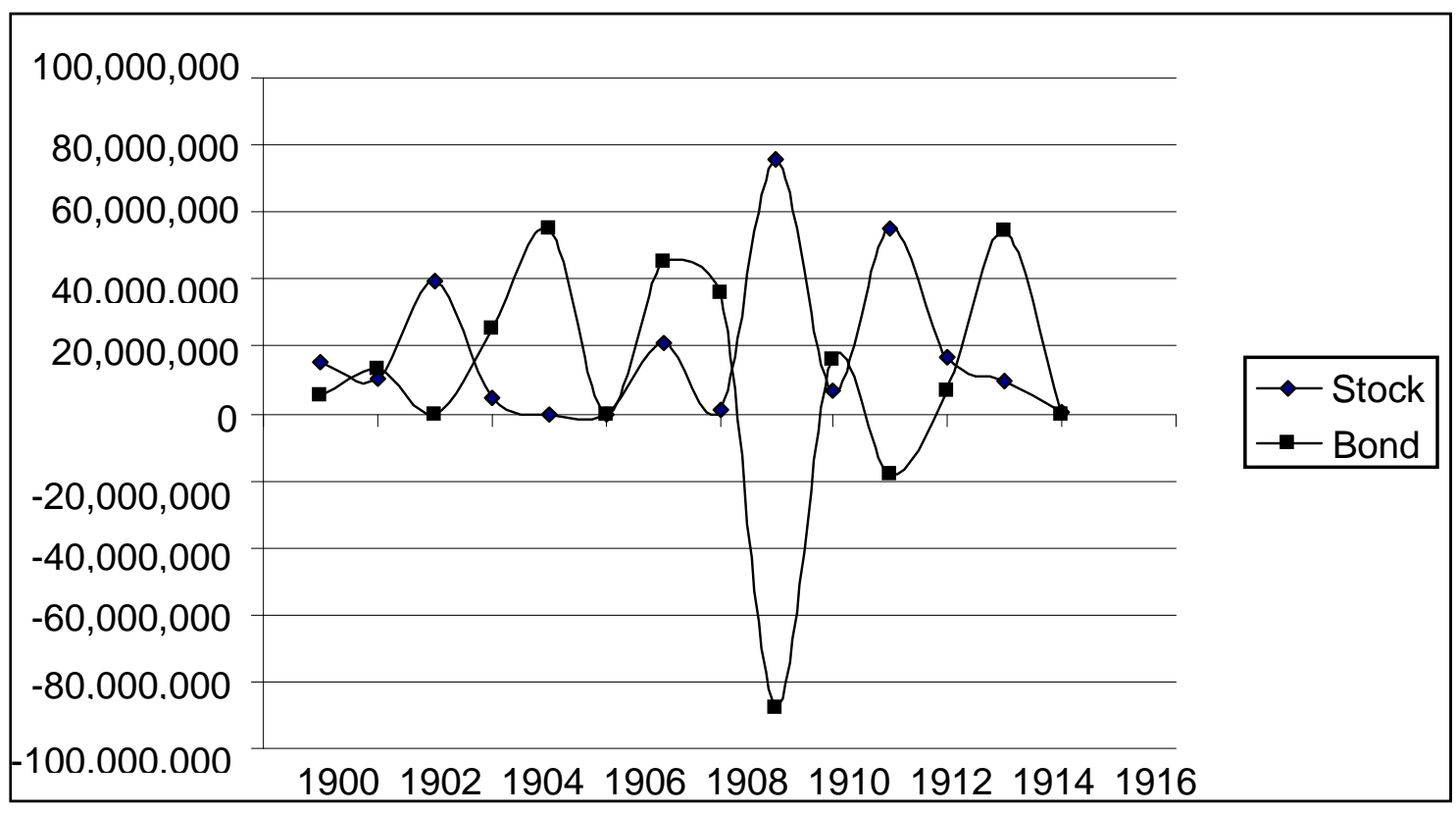

Source: Annual Reports, A.T.\&T

Figure 4: The Increase in the Amount of Stock Outstanding and Bonds Outstanding in A.T.\& T.

The bonds A. T. \& T. used were mainly collateral trust bonds and convertible bonds. As a holding company, A. T. \& T used the securities of its associated companies as collateral when it issued bonds to finance construction and improvement of those companies. Between 1900 and 1914, A. T. \& T. issued collateral bonds in amount of $\$ 78,000,000$. At the same time, the company issued a $\$ 150,000,000$ convertible bond to fund the development, to reimburse notes and to make loans to associated companies.[162] As mentioned above, mortgage bonds were not used because the significant portion of assets was not in real estate or facilities but securities of associated companies.

The connection between A. T. \&T. and investment bankers appeared from the formation of the company through debt financing. From 1901 to 1903 , the company 
floated \$28 million 4 per cent Collateral Trust Bonds due 1929, which were sold by a Boston investment banker, Kidder, Peabody \& Company. [163] In 1904, it sold \$20 million three-years 5 per cent notes by using Speyer \& Company and Lee, Higginson \& Company. In 1905, Kidder, Peabody \& Company and Baring Brothers Ltd. in London sold \$25 million Collateral Trust Bonds, of which \$10 million worth of bond were taken abroad.[164] In 1906, a $\$ 150$ million issue of convertible bonds was sold through a syndicate which included J. P. Morgan \& Company, Kuhn \& Loeb \& Company, Kidder, Peabody \& Company, and Baring Brothers Ltd. Similarly, in 1907, the company sold additional \$25 million Collateral Trust Bonds. This issue remained unsold in two years due to the economic recession at that time. In total, the company issued $\$ 228$ million worth of bonds and \$20 million notes with the financial support of investment bankers. President Fish's aspiration to expand the business made him less concerned about a surrender of control in management to bankers. [165]

Through investment bankers, A. T. \& T. successfully obtained foreign capital. According to Wilkins, the Barings in London took 6.5 million of the collateral bond issue of the company in 1905. It served also a manager of the underwriting syndicate of convertible bond issue in 1906 . The securities of the company were not only traded on the London Stock Exchange. They were also listed on the Amsterdam Exchange in Holland and the Paris Bourse in France. [166]

The influence of investment bankers based on their financial involvement was seen in the appointment of President Theodore N. Vail in 1907. Distrustful of Fish's financial and managerial strategy, investment bankers represented on the Board sought a new leader. Right after the election, President Vail named such bankers as H.L. 
Higginson of Lee, Higginson \& Co. and Robert Winsor of Kidder, Peabody \& Co. to the Board. Financial support from these investment bankers was indispensable for the expansion of the company.[167]

Meanwhile, the use of retained earnings increased before World War I, although it was still less important than security issues. The ratio of retained earnings to gross assets between 1900 and 1914 was from 10 per cent to 18 per cent except the depression years of 1907 and 1908. [168] Thus, retained earnings were not a major financial source for the gigantic company although it was profitable enough to accumulate earnings even after paying off high dividends. [169]

Under President Vail, A.T.\&T. expanded through acquisition of independent telephone companies. He justified it by insisting that the company was under the supervision and control of the government. However, in the end, the company was not free from anti-monopoly accusation. Right before World War I, A.T.\&T. was subject to a suit, accusing it of violation of the Sherman Act. To resolve the suit, the company agreed to "stop buying competing telephone companies and to connect them to its long distance lines.’[170]

\subsubsection{Corporate Finance from World War I to 1930}

During World War I, A.T. \& T. manufactured and furnished telephone facilities and equipment for the war emergency; it built many lines, underground cables, and toll switchboards in Washington, D. C., and established facilities and toll connections for military purpose. [171] In 1918, the Federal Government temporarily took over the telephone system. Under federalization, the government was responsible for maintaining 
property, for making provision for depreciation and obsolescence, and for paying all annual charges on securities. [172]

The size of war demand for new facilities and equipment was huge. In fact, fixed assets of the company increased by $\$ 221.9$ million or by 37.5 per cent during the war.[173] The expenditure for war emergency was mainly financed by debt, in particular, short-term notes. The increase in notes outstanding between 1917 and 1919 was $\$ 72.8$ million, while that of stock was $\$ 46.3$ million and that of bonds was $\$ 44.4$ million. [174] Federal control of the company made it difficult to offer new stock, and high interest rate in the financial market dissuaded the company from issuing long-term bonds.

After the war ended, the government returned the properties to the company in 1919. In spite of the post-war depression, the company needed to make a large investment in facilities, in part because of the soaring demand for telephone service and in part because of the shortage and exhaustion of plants due to the restriction on the use of capital and material during federal control. [175] The company also needed funds for acquisitions. Although before World War I the company promised not to buy any competing companies, following the anti-monopoly policy, the government allowed A.T. \& T.'s expansion through acquisition after the war; public policy was changed "from the preservation of competition to the achievement of efficiency", facing the post-war emergency. [176] In 1921, the ICC obtained power to exempt the company from antitrust laws for the acquisition purpose. As Peter Temin states, "of the 234 independent companies purchased under the ICC's jurisdiction, the Bell System acquired 223." [177] 
To meet these financial needs, a large part of the capital was raised through stock issues; the company, as in pre-war years, pursued a "safe proportion between capital and debt". [178] (Figure 5) From 1921 to 1929, the ratio of stock to gross assets accounts for between 52.5 per cent and 62.1 per cent, while that of bonds was between 20.7 per cent and 27.6 per cent. [179]

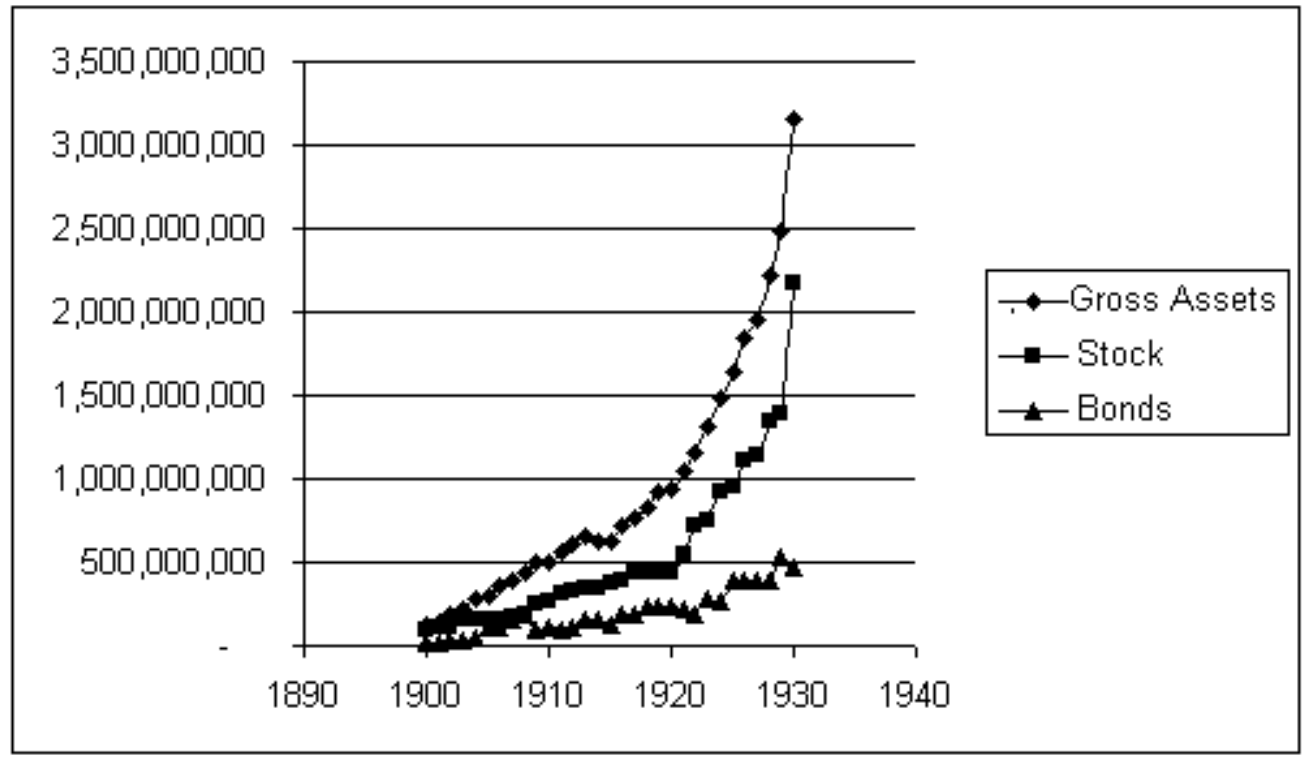

Source: Annual Reports

Figure 5: Long-Term Finance of the A.T. \& T.

To facilitate the subscription of the huge amount of stock, the A.T. \&T. took various actions. First of all, it maintained the regular dividend policy. While setting the dividend rate at 9 per cent annually after 1920, high enough to attract investors, the company rejected any extra or special dividends. The policy of stable dividend rate was regarded as "entirely consistent" with the safety of the investment. [180] The company also established in 1922 an organization called the Bell Telephone Securities Company. This new entity would "disseminate information about the securities of the Bell system to the public, especially to Bell Telephone subscribers," "advise intending investors," and 
"facilitate their transactions in our stocks and securities."[181] More important, the company sought new investors by adopting customer ownership; it invited telephone users to the subscription of securities. According to Ralph E. Heilman, the company had "effective machinery to reach the public in the important cities served by its various affiliated companies."[182]

The company adopted customer ownership not only to increase the number of shareholders but also to improve public relations. Wide distribution of securities to the public was "more than a plan to lay wider financial foundations of the Bell System....It will contribute to the promotion of national thrift, to the spread of a broader knowledge of investment, and to the development of machinery to assist investors. It will facilitate and strengthen the activities of all sound and helpful investment agencies. The nation is customer. Whatever promotes the prosperity of the nation promotes our prosperity."[183]

After 1920, the number of shareholders rapidly increased, and despite huge issues of stock, the number of stock par shareholders was consistent in the 1920s. (Figure 6) This is a result of acquisition of many competing companies and of customer ownership.

Although stock was the major financial source in A T. \& T., bonds continued to play a role in financing. Similar to pre- World War I period, the company relied on foreign markets to distribute its securities through investment bankers. Even during the World War I when foreign investment in the United States decreased in general, the company could raise funds in Holland. In the 1920s, it continued to attract foreign investors from European countries. [184]

On the other hand, the A.T. \& T. emphasized the importance of retained earnings. It repeatedly mentioned that "the company has never paid out all of its earnings 


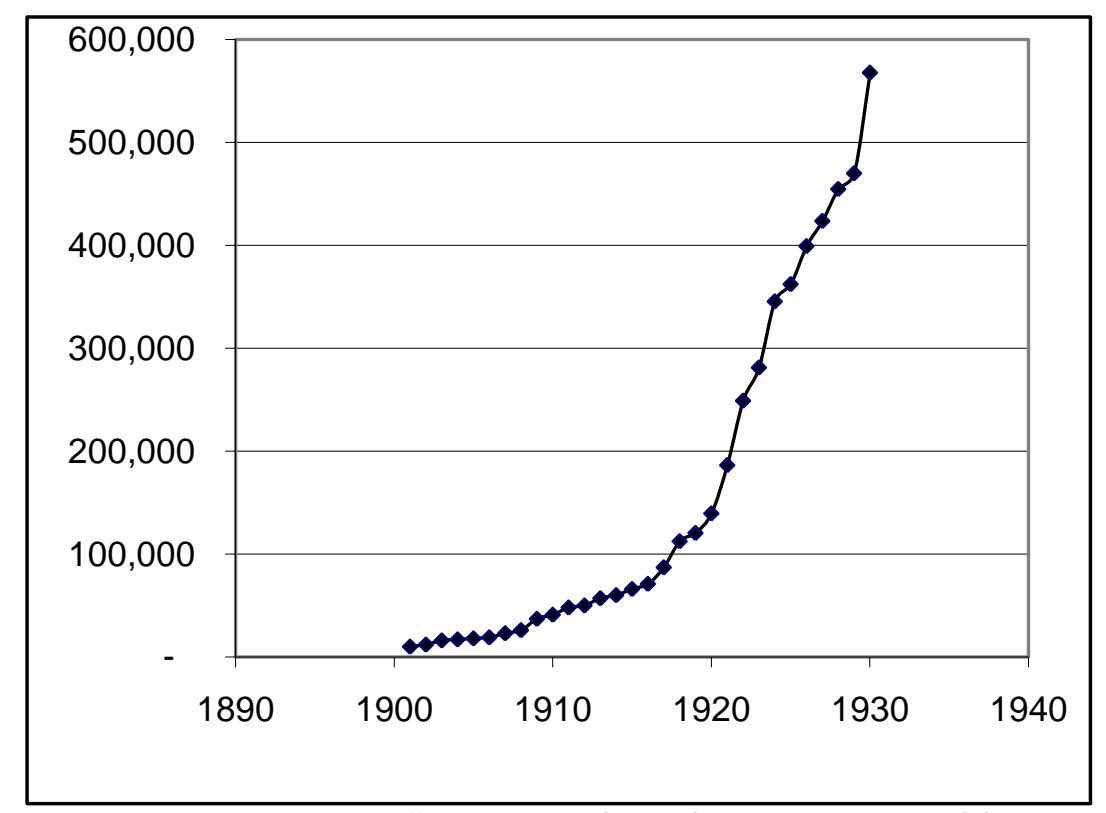

Source: Berle and Means, p55 Table VII

Figure 6: The Number of Shareholders in the American Telephone \& Telegraph Company.

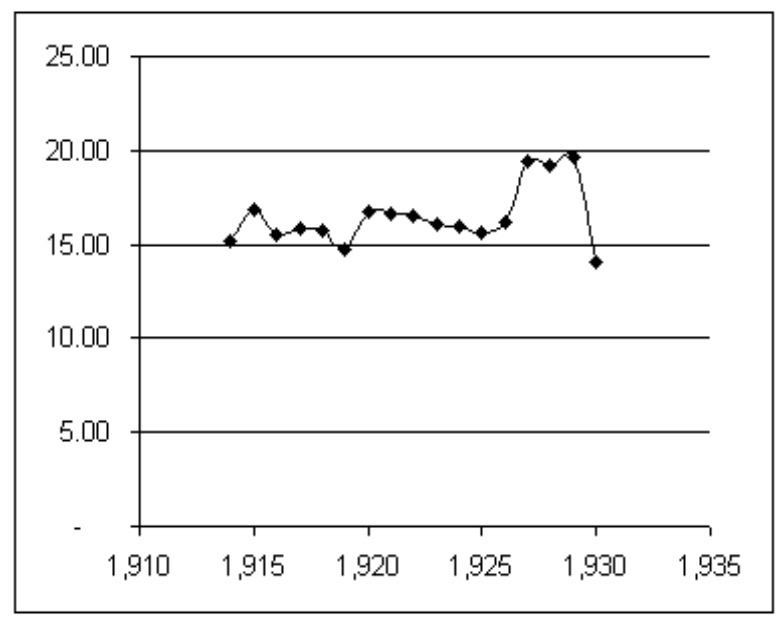

Source: Annual Reports

Figure 7: The Ratio of Retained Earnings to Gross Assets in the A.T. \& T.

in dividends, but has consistently pursued the policy of employing some of earnings in extending and improving its property." [185] It even affirmed that the use of earnings 
was "a uniform practice throughout the entire history" [186] In fact, the financial role of retained earnings increased only from 1927 to 1929 . The ratio of retained earnings to gross assets was between 14.7 and 16.9 per cent from 1914 to 1926 , and more than 19 per cent from 1927 to 1929. [187] (Figure 7). The lateness in using internal funds was in part explained by the restriction on earnings. As a monopolistic public utility, earnings of the company were subject to criticism. To control earnings, rates were determined under the supervision of state commissions, so that the company could make only "fair" return.

Thus, A.T.\& T. financed the growing need for funds mainly through equity finance except the years under President Fish. The stock of the company came to be widely held in the public along with the geographic expansion of the business. These financial features of the company were different from those of other public utility companies. The A.T.\& T. was an exception; the uniqueness of telephone business and the distinctive financial policies to conform with public anti-monopoly sentiments diverged its financial practices from those of other utilities companies.

\subsection{Industrial Finance, 1880-1930}

\subsubsection{Corporate Finance before World War I}

Following railroads and public utilities, large-scale industrial firms appeared in the 1890s. According to Alfred D. Chandler Jr., industrial corporations emerged only after railroads had drastically changed the American economy. From the 1840 s to 1880 s, railroads facilitated urbanization and enlarged markets, which led many manufacturing companies to adopt mass-production system. Along with the introduction of mass production, firms began to integrate vertically to coordinate purchasing, production, and

distribution. [188] At the turn of the century, another movement toward the formation of 
large-scale companies occurred. As Naomi Lamoreaux argues, large industrial firms faced serious price wars at that time. To prevent excessive competition, she argues, they expanded businesses through horizontal mergers. The passage of the New Jersey general corporation law in 1889, which allowed the establishment of holding companies, also facilitated horizontal integration. [189]

Although the emergence of big industrial businesses from the late nineteenth to the early twentieth century was a significant event in American business history, the size of these industrial firms was much smaller than that of major railroads and public utilities. Excluding one exceptionally huge business, the United States Steel Corporation, total assets of major American industrial firms before World War I was much smaller than those of major railroads and American Telephone \& Telegraph. Also, after the formation of public utility holding companies in the 1920s, total assets of the large utility companies overwhelmed those of industrial firms. [190]

The different size of firms from one sector to other was seen in the trend of capital intensity (capital/output). Figure 8 demonstrates clearly the high capital intensity of steam railroad and public utilities, especially electric light and power facilities, and how that declined over time. It also shows how low in relative terms was the capital intensity of manufacturing in general. Because of this high capital intensity of railroads and more important, electric light and power industry, there was a wide use of holding companies, for both management in general and management in finance in particular. In other words, railroads and public utilities required a huge cost to produce one unit of output. In order to increase output relative to capital, the firms attempted to improve managerial efficiency and reduce financial burden by adopting the holding company system. As the 
use of holding companies spread, their capital intensity became low. On the other hand, the manufacturing sector required the use of holding companies much less than railroads and public utilities due to its low capital intensity.

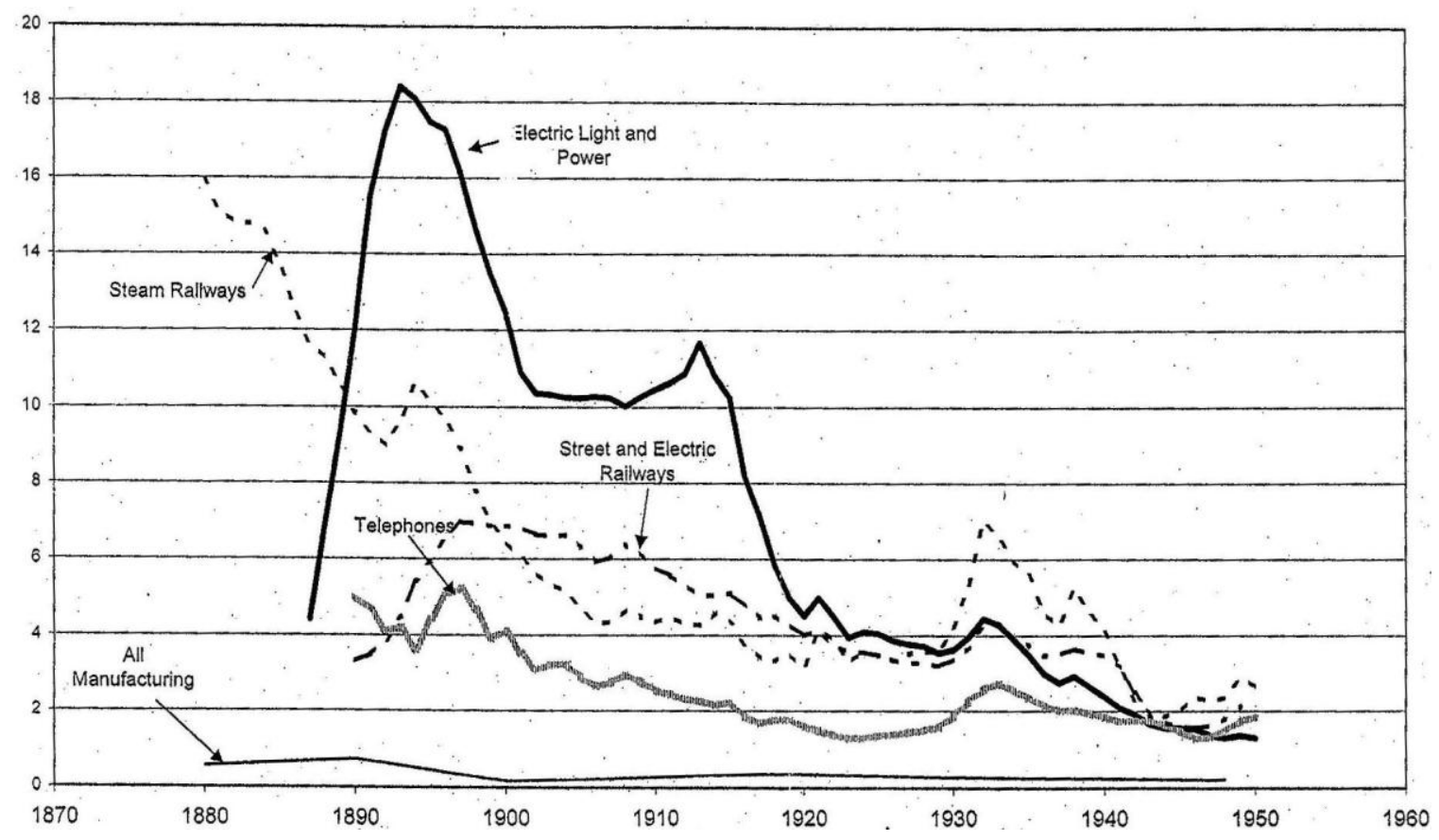

Source: William Hausman, Peter Hertner, and Mira Wilkins [191]

Figure 8: Capital/Output Ratio for U.S. Utilities, Transportation, and Manufacturing

Another significant difference between the large-scale industrial firms on one hand and public utilities and railroads on the other hand lay in the nature of the businesses. Railroads and public utilities provided services, which were indispensable for the community. To achieve better and cheaper services in the community, they were allowed to enjoy a monopoly within the community to the extent that they were under the supervision of the federal and state governments and made not more than "fair" returns.[192] The demand for public utility services was stable in general; railroads and 
public utilities could predict earnings in the future. In contrast, industrial companies as purely private entities were not allowed to take monopolistic advantage and the demand for the commodity they produced was intensely fluctuated compared with that of the services provided by railroads and public utilities.

The smaller scale of business, the exposure to intense competition, and the unstable demand all affected the finance of industrial firms; industrial firms heavily relied on equity finance. Relatively small demand for funds in industrial firms made it possible to raise enough funds from common stock issues. Also, common stock issues alleviated risk of insolvency due to competition and unstable income. Firms that issued stock did not incur the large fixed charges on funded debt and the payment of cumulative dividends on preferred stock. [193]

Next to common stock, industrial firms issued preferred stock, which represented the value of plants. While preferred stock did not require interest payment like bonds, it had priority over common stock in the distribution of profits. The dividend rate of preferred stock in industrial firms was higher than that of railroads and public utilities because industrial firms sought to attract investors. As semi-speculative investment, preferred stock was more salable than common stock. [194]

The use of bonds was the least common. Industrial firms were not willing to take financial responsibility associated with bond issue, given the fluctuation of earnings in industries. In fact, industrial bonds were regarded as inferior to those of railroads and public utilities. [195] Among bonds, in contrast with railroads and public utilities, industrial firms more often used debenture bonds. Dewing explains that "a long cherished prejudice among bankers and shareholders against direct mortgages on a manufacturing 
plant." led to the aversion of mortgage bonds. [196] Also, collateral trust bonds were adopted in the middle of the great merger movement in the turn of the nineteenth century.[197]

Industrial preferred stock and bonds were usually sold through investment bankers. After the decline of railroad companies in the 1890s, investment bankers came to take an active role in industrial finance besides public utility finance. Especially, they raised funds to create gigantic industrial firms. For example, J.P. Morgan \& Co. initiated the formation of General Electric Company and United States Steel Corporation. Through their financial power, investment banks not only distributed bonds and other securities of these companies, but also obtained director positions in order to control management.[198]

On the other hand, short-term financing was not important for large corporations. Although the ratio of current assets to gross assets in industrial firms was much higher than that of railroads and public utilities, most of current assets were often financed by the sale of securities. The companies were reluctant to borrow short-term funds, which might cause insolvency should demand for manufactured goods decline. [199]

\subsubsection{Corporate Finance from World War to 1930}

The growth of the size of industrial firms accelerated during and after World War I. Although the impact of World War I was different from industry to industry, big corporations in major industries such as steel, chemicals, electric appliances and automobiles experienced rapid growth in investment due to large military orders from the U.S. and foreign governments. After the post-war recession in the early 1920s, large 
corporations turned to mergers and acquisitions and increased investments in subsidiaries and affiliates. [200]

This increasing demand for capital was met not only by stocks but by internal funds as well. Huge profits made during the war years enabled them to use accumulated earnings. John Litner argues that they relied on internal funds for 79 per cent of the expansion of gross assets between 1921 and 1924, 91 per cent between 1924 and 1927, and 97 per cent between 1926 and 1929. [201] Similarly, Albert Ralph Koch shows the importance of internal funds in financing by using the statistical data of 84 large manufacturing companies (Table 7). In most years between 1921 and 1930, the amount of internal funds were larger the funds raised through the sales of securities. Considering retirement of securities, new funds obtained through securities were much smaller than internal funds. By using internal funds, the companies could avoid the payments of high dividends and interests and financier's control over management.

(in Million Dollars)

\begin{tabular}{|r|r|r|r|r|}
\hline & \multicolumn{1}{|l|}{ Fixed Capital } & Securities Sale & $\begin{array}{l}\text { New funds from } \\
\text { securities }\end{array}$ & \multicolumn{1}{l|}{$\begin{array}{l}\text { Internal } \\
\text { Funds }\end{array}$} \\
\hline 1921 & 566 & $344(61)$ & & $142(25)$ \\
\hline 1922 & 431 & $222(52)$ & $60(14)$ & $488(113)$ \\
\hline 1923 & 865 & $402(46)$ & $297(34)$ & $745(86)$ \\
\hline 1924 & 558 & $136(24)$ & $35(6)$ & $772(138)$ \\
\hline 1925 & 806 & $314(39)$ & $42(5)$ & $1,053(131)$ \\
\hline 1926 & 1,015 & $335(33)$ & $188(19)$ & $1,107(109)$ \\
\hline 1927 & 1,034 & $447(43)$ & $148(14)$ & $912(88)$ \\
\hline 1928 & 1,001 & $265(26)$ & $83(8)$ & $1,246(124)$ \\
\hline 1929 & 1,717 & $1,239(72)$ & $564(33)$ & $1,459(85)$ \\
\hline 1930 & 1,291 & $340(26)$ & $183(14)$ & $717(56)$ \\
\hline
\end{tabular}

Source: Koch, p103, Table 13

* Per cent of fixed capital is indicated in parenthesis.

Table 7: Long-Term Financing of the Industrial Sector 
Another feature of the post-war industrial corporate financial practices was the active role of investment bankers in the sale of stock. According to Dewing, bankers could obtain higher margin of profit on stock than on bonds at that time. These bankers were able to sell speculative stock, responding the increasing demand of investors in the booming 1920 s for stock. Since new investors who sought large returns during the postwar economic boom were not knowledgeable about industrial shares, they were easily persuaded to subscribe. Even conservative investors put money into speculative stocks to obtain higher returns. In addition, the prosperity of manufacturing since the war accelerated the popularity of industrial stock. [202]

In spite of the significant role of stock in industrial finance, however, the use of bonds was still vital. Koch finds that from 1922 to 1927, firms in his manufacturing sample sold more bonds than common stock. Although the new funds obtained through the sale of bonds decreased due to a huge amount of bonds retired, the companies were still optimistic in issuing bonds even under the condition that stock prices rose faster than bond prices at that time. [203]

Thus, while equity finance was an important element of industrial finance, internal funds came to play a significant role and bond issues continued to be an important financial source. The importance of bonds and internal funds in industrial finance was seen in the case of the United States Steel Corporation, one of the biggest industrial companies. 


\subsubsection{The United States Steel Corporation}

\subsubsection{Corporate Finance before World War I}

The United States Steel Corporation was formed as a holding company under the plan made by financier, J.P. Morgan \& Co. At the end of the nineteenth century, the steel industry experienced ruinous competition; the producers of primary steel attempted to enter the production of finished products, while producers of finished products tried to make inroads to primary production in order to secure raw materials. Such competition led to decreasing returns and in turn the stopping of dividends. In the end, it would result in "a heavy fall in the value of steel stocks". The decline of the stock prices caused a significant loss to the owners of the steel plants as well as promoters and financiers who still held a large block of the stock. Financiers were also afraid of the loss of confidence from the public investors. To bring the stability in the industry and to prevent excessive competition, J. P Morgan \& Co. planned to unite all conflicting steel interests into one corporation, which owned more than a majority of interest of the constituent companies to control them. [204]

Thus, United States Steel was incorporated in New Jersey in 1901 by amalgamating the leading steel companies, including the Carnegie Steel Co., the Federal Steel Co., the American Steel \& Wire Co., the National Tube Co., the National Steel Co., the American Tin Plate Co., the American Steel Hoop Co., and the American Sheet Steel Co., and other transportation and mining concerns. [205] Right after the organization, the company also took over the American Bridge Co. and John D. Rockefeller's Lake Superior Consolidated Mines. To organize the corporation, it was authorized to issue $\$ 550$ million of common stock, $\$ 550$ million of 7 per cent cumulative preferred stock, 
and $\$ 304$ million of 5 per cent Mortgage Collateral Trust Bonds. In order to achieve consolidation, it issued $\$ 1,297,184,170$ of stocks and bonds in exchange for $\$ 894,988,800$ of stocks and bonds of the constituent companies. This meant that during the formation of the company, stock watering amounting to one-thirds of capital was created. [206]

From the beginning, the United States Steel Corporation was gigantic in its capital, scale, and output. In the early twentieth century, the capitalization of more than $\$ 1$ billion was unprecedented among industrial firms. United States Steel controlled more than two hundred manufacturing plants and transportation companies, and owned a number of mine, ore, and coke properties. [207] Controlling raw materials, production, and distribution, the company's output of Bessemer steel ore was about 90 per cent of the output in the country and that of the estimated amount of iron ore deposit was about 70 per cent. [208]

With its concentrated capital, its dominance over the markets of primary as well as finished products, and control over major steel companies, the company could not avoid the accusation of monopoly. The government repeatedly alleged that the corporation should be dissolved due to its restraint of trade and the exercise of monopoly power. Unlike public utilities, the big business as a private entity was not allowed to retain monopolistic power. Against this challenge, Elbert H. Gary, the chairman of the company, stated that the corporation had never had monopoly or the intention of forming monopoly. He emphasized that "the existence of Corporation has been of benefit and not of injury to its employees, its customers, its competitors, and the general public.” [209] As a consequence, the government suits were dismissed. In 1915, the Federal Court at 
Trenton, New Jersey, applied the "rule of reason"; "The Corporation was organized for business reasons and had purchased its various plants to promote such business and not to restrain trade or obtain a monopoly." [210] Five year later, again, the U.S. Supreme Court affirmed that the corporation did not achieve monopoly, opposing dissolution. The decision also stated that the dissolution infringed public interest; it would cause "a material disturbance" and "serious detriment to the foreign trade". [211] The ambiguity of the Sherman Act and the importance of steel industry in the national economy enabled the corporation to continue its business.

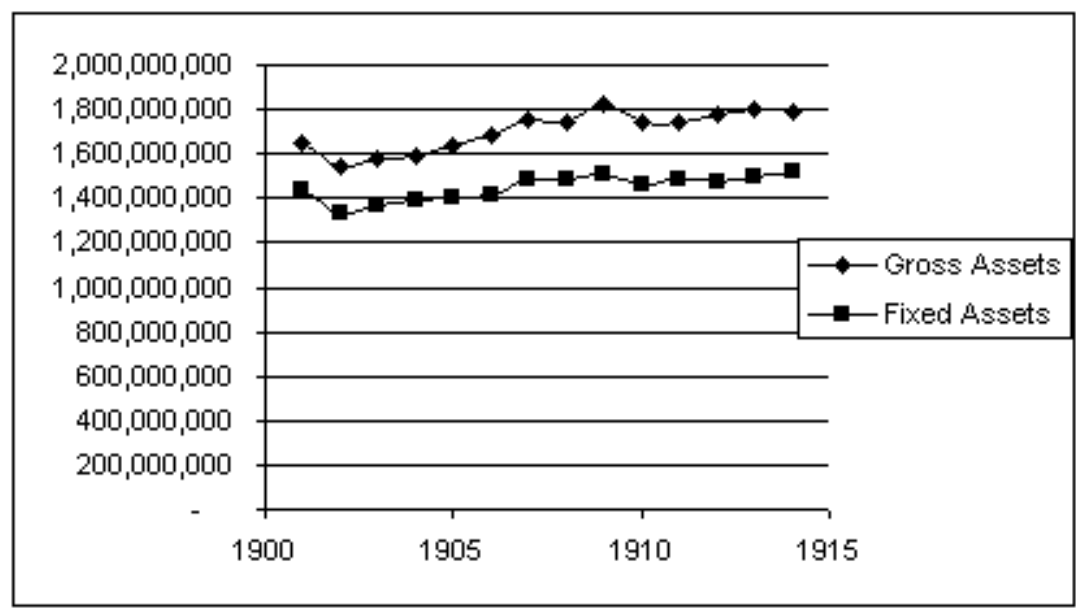

Source: Annual Reports, the U.S. Steel

Figure 9: Gross Assets and Fixed Assets of the United States Steel.

After the formation of the corporation, its financial structure was consistent. The amount of gross assets from 1901 to 1914 was between $\$ 1,546$ million and $\$ 1,801$ million; its growth was slow. Of gross assets, fixed assets, especially the property account, was a major component. Through vertical as well as horizontal consolidation, the corporation held not only manufacturing properties but also properties for raw materials such as ore, coal, and cork, and even transportation properties. (Figure 9) As a 
result, the ratio of fixed to gross assets was high for an industrial firm; it marked more than 80 per cent.

Gross assets were paid for mainly by stocks. Before World War I, stocks financed almost a half of gross assets. However, it is noteworthy that stock had not been issued since the formation of the company. As Edward Sherwood Meade explains, most of industrial combinations did not issue new securities after the promotion period. Instead of new stock issues, they needed to "absorb the excess of capitalization by reinvesting of earnings.’[212]

The company used both common and preferred stock. Since both had equal voting power, the difference between the two was the dividend rate. Although the company was not obliged to pay common stock dividends, it paid a regular dividend nonetheless, usually 5 per cent annually. Meanwhile, the dividend rate of its preferred stock was 7 per cent cumulative. The company at first issued both common and preferred stocks in the same amount, but in 1903, it converted 7 per cent preferred stock in amount of $\$ 150,000,000$ into 5 per cent bonds probably to reduce costs for capital. (Figure 9)

The huge amount of stock was widely held in the public. The number of the common shareholders gradually increased from 1901 to 1914, while the amount of stock outstanding did not change. Also, the stockholding of the largest shareholders was minimal. For example, in 1910, J.P Morgan \& Co. owned \$18,000,000 of common stock, equivalent to 3 per cent to the stock outstanding at that time. Even adding J.P Morgan's individual holding only raised the total to 6.6 per cent. The other shareholder, the Dutch Syndicate held $\$ 21,687,000$ of common stock, or 4.1 per cent of stock outstanding. As 
for the president of the company, W. E. Corley, the amount of stock he owned was $\$ 113,200,000$, only 0.002 per cent. [213]

Stock of the company was also widely distributed in foreign countries. The Rothschilds in London invested in common stock before World War I. In France, in 1909 common stock of the company was not allowed to be listed on the Paris Burse, but the French could buy it "from bankers and brokers in France or on other stock exchange.[214]

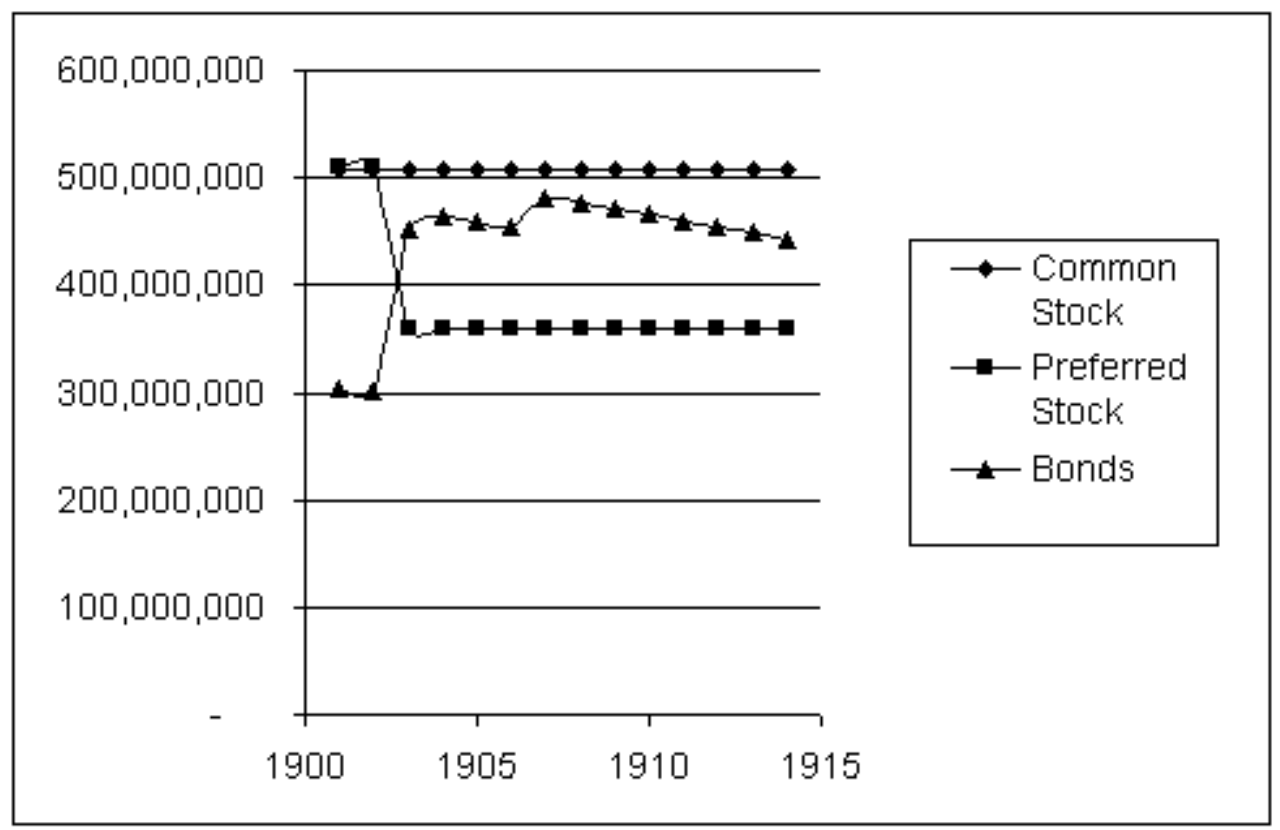

Source: Annual Reports, the U.S. Steel

Figure 10: Stocks and Bonds Outstanding of the United States Steel.

Unlike most of industrial firms, the corporation used bonds more than preferred stock. (Figure 10). In 1903, the corporation authorized $\$ 250,000,0005$ per cent 10 to 60 year collateral trust bonds. $\$ 200,000,000$ out of $\$ 250,000,000$ bonds were issued, of which $\$ 150,000,000$ was used for the conversion into the same amount of preferred stock 
at that time as explained above. This was an interesting financial scheme, compared with railroad finance.[215] While many railroad companies under reconstruction attempted to reduce fixed charges by converting bonds into preferred stock, the corporation tried to avoid the payment of high preferred dividend by increasing fixed charges of bonds. U.S. Steel's good financial standing, high dividend on preferred stock, and the policy to pay off regular dividends to attract investors, all made it advantageous for the corporation to use more bonds than preferred stock.

The company also used internal funds. The ratio of internal funds to gross assets increased from 10.5 per cent in 1905 to 20 per cent in 1914.[216] The ratio was smaller than that of stocks and bonds because of large capitalization during the formation of the corporation. However, internal funds were still an important financial source for the corporation. In fact, the amounts of "allowance for depreciation, replacement, additional property, and new plants and the discharge of capital obligations" were larger than those of dividends, and the corporation still had undivided surplus. [217] As the Commercial and Financial Chronicle noted, the corporation and its subsidiaries spent $\$ 463,817,201$ on capital account from 1901 to 1909 , which included additional plant, construction, improvements, and retirement of bonds, mortgages, and other obligations. Against these outlays, "the amount of new bonds and other obligations issued was only $\$ 59,482,593 . "$ The rest of the $\$ 344,334,608$ was paid out of appropriated earnings and the surplus. [218] United States Steel was one of the first industrial firms that investment bankers were deeply involved in its formation and finance. As explained above, J. P. Morgan \& Co. took an initiative to establish the corporation through the consolidation of major steel companies. To carry out the consolidation plan, it organized a large syndicate to 
underwrite the securities of the corporation in amount of $\$ 200$ million. It was allotted not only to domestic investors but also those in Britain, Netherland, Germany and France. As a major financial agency, interest of J.P. Morgan \& Co. was represented on the Board of Directors by three persons, J. Pierpont Morgan, Robert Bacon, and Charles Steele. Through directorship, they were able to supervise and control the management and finance of the corporation in order to maintain the confidence in the company and in themselves from the public. [219]

J.P Morgan \& Co. continued to provide financial support to the company after its formation. When the company issued \$200 million Collateral Trust Bonds to change preferred stock for the new bonds, it again organized a syndicate to underwrite $\$ 100$ million of the securities. It was difficult to achieve conversion at that time; due to stock watering, stock price of the company was declining. Under the difficult situation, J.P. Morgan underwrote the operation of $\$ 80$ million in preferred conversion and the sale of $\$ 20$ million bonds. [220] Although there were many challenges against investment bankers in the early twentieth century, the company maintained strong ties with investment bankers to meet its gigantic financial needs.

\subsubsection{Corporate Finance from World War I to 1930}

The outbreak of the War in Europe in 1914 had a favorable impact on the corporation. The huge demand from foreign countries resulted in an increase in the volume of business and rise in prices of its products. [221] After the United States entered the war in 1917, the business prospered further with the increase in order from the federal government. From 1914 to 1918, the growth of gross assets of the company

was much faster than pre-war years. (Figure 11) It increased from 1,792 million in 1914 
to $\$ 2,572$ million in 1918 , or by $\$ 780$ million, of which the increase in property accounted for $\$ 106$ million and, current assets including cash and inventories for $\$ 614$ million.[222]

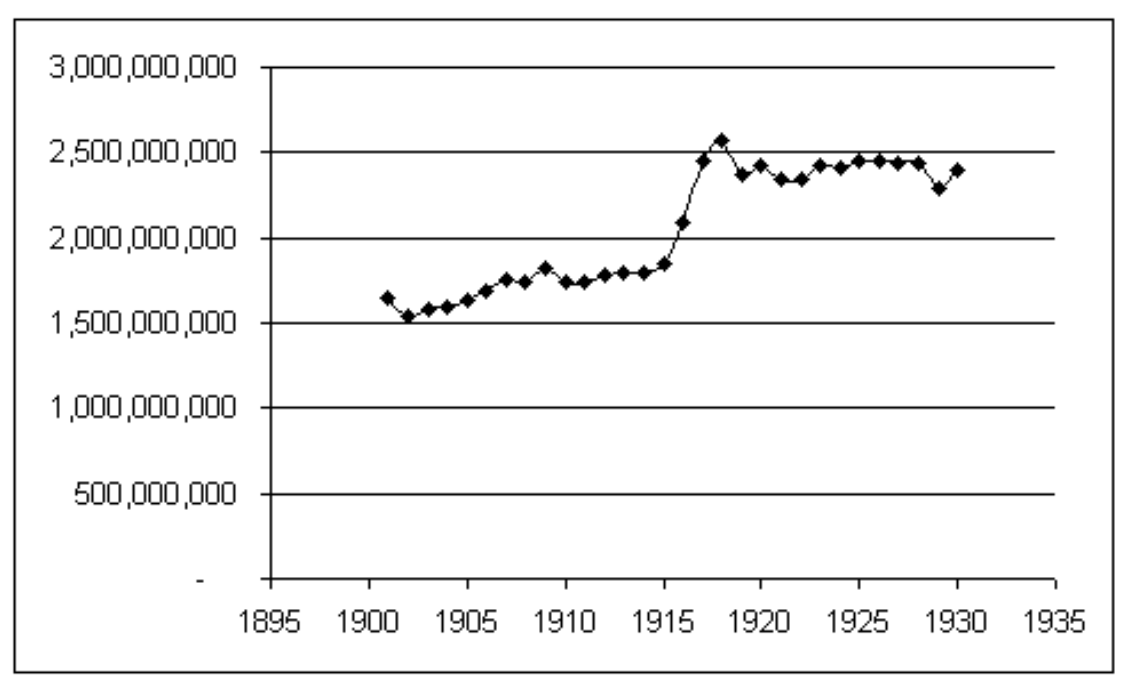

Source: Annual Reports, The U.S. Steel

Figure 11: The Increase in Gross Assets of the U.S. Steel.

To meet the increasing financial demand, no long-term securities were issued; the corporation rather preferred to use notes issued by subsidiaries, which it guaranteed. The account of subsidiaries' notes appeared in the annual report of 1914 for the first time in amount of $\$ 26,970,001$, increasing to $\$ 33,912,076$ in 1918 . Considering high interest and dividend rates at that time, short-term finance was the best choice to economize financial costs.

More important, the corporation came to rely on internal funds more heavily than before. The ratio of internal funds to gross assets almost doubled, from 20.6 per cent in 1914 to nearly 40 per cent in 1919 . The accumulation of surplus during the war facilitated this financial trend. The sum of depreciation, reserves, and surplus increased from 
$\$ 407,660,749$ in 1914 to $\$ 1,082,626,708$ in 1919 . As Figure 12 shows, the growth of the internal funds during the war was much faster than that of pre-war years.

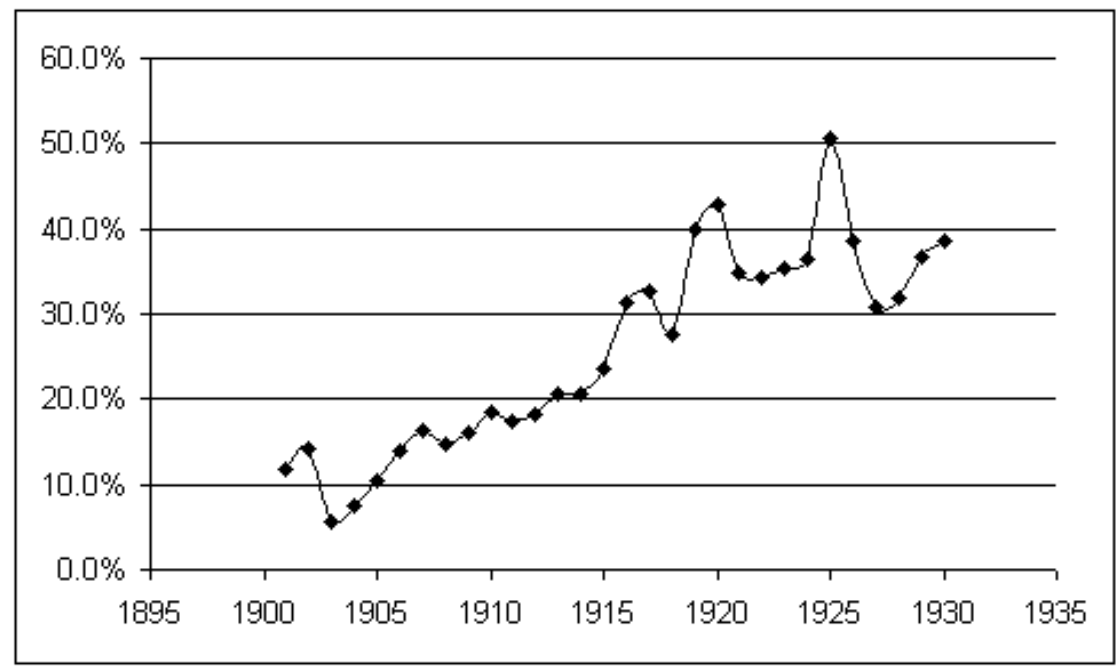

Source: Annual Reports, the U.S. Steel

Figure 12: The Ratio of Internal Funds to Gross Assets in the U.S. Steel.

The war also changed the structure of stock ownership. Before the war, foreign investors subscribed to the stock of the company. However, because of the war emergency, many of them disposed of their stocks. 1,285,636 shares of common stock and 312,311 shares of preferred stock were held abroad in March of 1914, but the number of shares decreased to 491,580 shares and 148,125 shares respectively in December of 1919.[223] After the war began in Europe, the number of shareholders had decreased temporarily in part because of this return of the stocks to United States from Europe. However, it again rapidly increased after 1916. (Figure 13) The number of shares per shareholders continued to decrease until 1921. Probably, those stocks returned to the United States were widely distributed to the public due to high dividends at that time. The 
company, making huge profits, paid off extra dividends in addition to 5 per cent of regular dividends after 1916. [224]

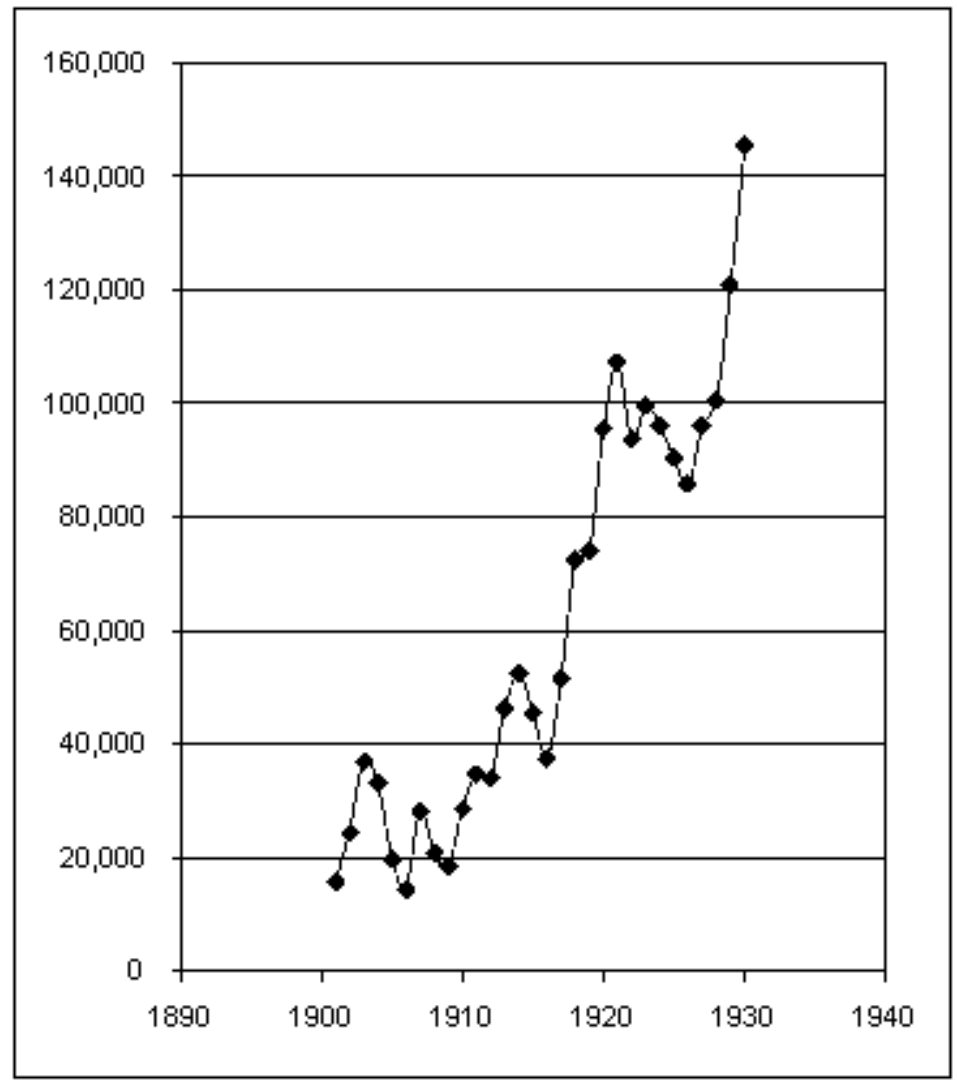

Source: Berle and Means, p55, Table VII

Figure 13: The Number of Shareholders

In the 1920s, gross assets of the company had not significantly changed. (Figure 11) Also, the increase in the investment in properties was moderate; from $\$ 1,607$ million in 1920 to $\$ 1,710$ million at its peak in 1927. In fact, however, the corporation spent much larger amounts of money to replace old plants and to establish modern equipment. Those expenditures were charged off from internal funds. The amount of internal funds was larger than stock outstanding. The ratio of internal funds to gross assets also shows 
the upward trend in general, while repeating upward and downward movements. The ratio increased from 27.7 per cent in 1918 to 50.7 per cent in 1925 . After the decline in a few years, it shows 38.6 per cent in 1930.[225] (Figure 12) The corporation's heavy reliance on internal funds is demonstrated in the testimony of Edward R. Stettinius Jr., the Chairman of the Board of the United States Steel Corporation during Hearings before the Temporary National Economic Commission in 1937. When Leon Henderson on the committee of the TNEC, asked whether the company had had "any substantial outside financing," Stettinius answered "no." To Henderson's next question, “So your capacity was maintained principally from internal financing?" he affirmed that that was correct.[226]

The role of common stock was important only in the late 1920s. In 1927, the corporation issued common and preferred stock in amount of $\$ 203,321,000$ as dividends to its shareholders. This was the first issue after the promotion of the company. The purpose of the issue was additions and improvements of properties. In 1929, it also issued common stock of $\$ 101,660,500$ for the same purpose. This issue was allocated to existing shareholders at $\$ 140$ per share. 99.3 per cent of the stock was subscribed, and the rest was sold in the market. Furthermore, in the next year, it issued the stock of $\$ 53,643,800$ to acquire three companies such as the Atlas Portland Cement Co., The Columbia Steel Co., and Oil Well Supply Company. As a result of the increase in common stock outstanding, the ratio of common and preferred stock to gross assets jumped up from 35 per cent in 1926 to 44 per cent in 1927 and to 51 per cent in 1930. [227]

Although common and preferred share was still held abroad in the 1920s, foreign shareholding was no longer significant. In 1927, it accounted for 2.7 per cent only to total 
shares. Wilkins attributes the decline in foreign capital to "the maturity of the American steel industry." Foreign investors preferred "more vibrant sectors within the economy.’’228]

On the other hand, bonds were not issued at that time. Unlike railroad and utility companies, the company was reluctant to pay high interest rates and even did not believe the market could provide sufficient capital to meet its financial demand. Then, Chairman of the Board, Gary stated in 1920 that "Do you think our corporation would be in a good position as it is if we had to borrow money at the present time, like some of other large business institutions who are paying 7 or 8 per cent for their money? If we borrowed in the same proportion to other borrowers that is our business is to their lines of business, I think, Gentlemen, we would bring on a financial panic within a very short time." [229]

Thus, the United States Steel Corporation heavily relied on equity finance during the promotion period. However, its expansion after promotion was mostly financed by other financial sources, bonds and later, internal funds. This was a result of overcapitalization of the company at the time of its formation. The company was not able to issue stocks due to stock watering; it had to absorb the water by using internal funds. In its early years, since the high dividend rates hampered its ability to accumulate internal funds, it had to mainly rely on bond issues. As profits of the business increased after World War I, it was able to accrue depreciation, reserves, and undivided surplus even after the payment of huge amounts of dividends.

\subsection{Conclusion}

The notion that large American firms came to rely heavily on equity financing in the early twentieth century is not borne out by a careful study of different sectors of the 
economy. Corporate financial practices differed from industry to industry and from firm to firm. They also changed across time. In fact, the railroad industry relied on stocks in its very beginning only. From the 1880 s to World War I, its major financial source was bonds. A significant amount of these bonds were marketed in foreign countries. In the 1920s, as the financial conditions were not favorable to sell securities and its surplus increased, it turned to the use of internal funds. Meanwhile, since the public utility sector served a wider section of the public than railroads, it was likely to sell more stocks to the public. However, its major financial source was bonds. In its early years, stocks of public utilities were not marketable because investors regarded them as risky. Even when public utilities prospered in the 1920 s, bonds were indispensable in order to meet their huge financial needs. These bonds were mostly domestic bonds; compared with railroads, the foreign capital was less important in general. In contrast, the industrial sector, which required relatively small amounts of capital, faced intensive competition, and bore high risk, relied on equity before World War I. After the war, however, large industrial corporations that accumulated surplus turned to the use of internal funds. Since industrial securities were regarded as risky, foreign investors were usually reluctant to invest in them.

At the level of the firm, corporate financial practices were even more complex. The three big business examined in this chapter do not necessarily fit the financial practices in each sector. Before World War I, the Pennsylvania Railroad relied on common stock, disliking the increase in fixed charges through bonded debts. A. T. \& T. also used stock as a major financial source, except the years of President Fish. To maintain equity finance, it paid regularly high dividends, facilitated customer ownership, 
and distributed the information about its business and stock. The company also raised funds from foreign countries; the growing business could attract foreign investors. Although the United States Steel Corporation relied on huge stock issues at its promotion and the end of 1920s, it used bonds and internal funds only for its expansion in other years. The company also used a huge amount of foreign capital before World War I. The foreign investors were confident in the huge industrial business. However, after World War I, due to the maturity of the industry, foreign stock drastically declined.

In their classic text, Berle and Means argued that wide distribution of stock weakened the power of small shareholders and allowed managers to obtain control. To prove this trend, they used the cases of the three big businesses, the Pennsylvania Railroad, the A.T. \&T., and the United States Steel. However, they were the biggest companies in the industries; they were exceptions in the size of financial demand, and in confidence of the financial institutions and the public. Hence, their financial practices were also exceptional to general patterns in their industrial sectors. Berle and Means interpretation of corporate financial practices has overemphasized a few exceptional cases.

Scholarship has often characterized American corporate finance as equity finance, attributing it to American market-oriented culture. However, corporate financial practices were not static. Such factors as the size of the business, the power over the market, and the nature and risk of business, diversified corporate financial practices, and government antitrust policy influenced corporate financial decisions. These environmental factors were not stationary either. Along with economic, financial, and managerial improvements, some companies grew bigger in size, obtained concentrative 
power over the markets, and reduced their risks. These changes directly affected corporate financial practices. Also, other external incidents, including the change of economic policy, business cycles, and the impact of wars transformed corporate finance across time. Although securities markets had developed since the early nineteenth century in the United States, American corporate finance did not always relied on the markets. 


\section{Chapter 3}

\section{VARIETIES OF CORPORATE FINANCE IN JAPANESE}

\section{INDUSTRIALIZATION}

\subsection{Introduction}

Many economic historians have argued that national patterns of Japanese corporate financial practices were associated with corporate group called keiretsu, which appeared after World War II. A main bank included in each keiretsu played a role as a major financier for group companies. Before the war, there was another corporate group called zaibatsu as a predecessor of keiretsu. Zaibatsu emerged around the 1880 "as a family-owned, diversified group of businesses" under the government support. [230] According to the notion of path dependency, group-oriented culture seen in corporate groups would create nation-specific institutions. Both keiretsu and zaibatsu shared their fundamental features as groups: close ties and mutual support within a group persist and create bank-centered financial institutions and financial practices. Japanese firm's reliance on bank loans has been thought to fit the Gerschenkron model; Japan, often regarded as a latecomer of industrialization, would need bankers' support for its economic growth. In fact, however, corporate financial practices of major industries in Japan, railroads, electric utilities and cotton spinning, were far from bank loans.

This chapter shows how corporate finance in the early industrialization of Japan was different from that of post-war Japan and the Gerschenkron model, and how corporate financial practices differed from industry to industry. Although Japanese government had attempted to establish modern banking system since the late nineteenth 
century, the major industries heavily relied on the securities markets with indirect support from banks. On the other hand, their financial practices were not the same. Different industries developed different financial practices from each other.

\subsection{The Development of Financial Institutions}

Modern financial institutions in Japan developed with strong governmental support in the Meiji Period. Although there were a few financial institutions that dealt with loans, deposits, and notes under the previous Tokugawa Shogunate regime, all collapsed along with the fall of the Shogunate in 1867 and the subsequent Meiji Restoration. [231] In the midst of economic and financial bewilderment after the Restoration, the Meiji government became deeply involved in building up modern financial institutions in order to catch up with western economies.

In 1872, the government promulgated the National Banking Act, modeled after comparable legislation passed in the United States during the Civil War. The American national banking system was established, aiming to "reform heterogeneous state bank currencies into a more uniform national currency.'[232] National banks were required to buy U.S. government bonds in dollar amount of one-third of their paid-in capital stock. The banks deposited these bonds with the U.S. Treasurer and received notes. [233] With this method, the banks obtained the privilege of bank note issue. In similar way, Japanese national banks were now granted the privilege of bank note issues. They were required to buy government bonds called kinsatu kosai shosho, in equivalent amounts of 60 per cent of their capital. The banks deposited these bonds to the government and received bank notes. [234] 
The Japanese national banks were expected to redeem with specie the inconvertible notes issued by the government. However, the increase in the number of the banks stagnated due to the lack of hard currency for bond redemption. In 1876, the government amended the Act to facilitate the establishment of additional banks. The revised Act abolished the requirement of note conversion and allowed the use of national bonds, called "kinroku kosai" issued to the nobility and old warrior class for banks' capital requirements. [235] As a result of the revision of the Act, the number of national banks jumped up from 4 in 1876 to 153 by 1879 . In 1883 , however, the government prohibited establishment of any new banks, since the amount of bank notes in circulation exceeded the upper limit set by the government. [236]

In the meantime, private banking businesses appeared as early as in the 1870 s. Without any regulation, most of the banking businesses were small in size, with little capital and limits on the amount of credit they could create. After 1876, with the revision of the National Banking Act, the government for the first time regulated the private commercial banks called, "ordinary banks." They were required to receive authorization from the government to begin banking activity. The number of ordinary banks rapidly increased after the government prohibited the formation of national banks in 1883. [237] The Banking Act of 1890 allowed the expansion of the financial activity of ordinary banks. Putting them under strict supervision of the government, the 1890 Act increased the public's faith in the banks, leading to more deposits and greatly increased credit creation by the banks. [238]

Although the Banking Act of 1890 defined ordinary banks as merely commercial banks dealing with short-term deposit and loans, they came to play a role in industrial 
finance as securities banks. [239] The major role of the banks before World War I was financing growing industries in the form of stock collateral loans; they made loans to investors, receiving stock as collateral. After World War I, they participated in underwriting bonds and played a role as trustees by having charge of collaterals for the securities.

In order to connect these banks and to facilitate financial activity, the Meiji Government established a central bank, the Bank of Japan, in 1882, modeling it after the National Bank of Belgium (Banque Nationale de Belgique). [240] Half of its capital was provided by the government. The Bank not only enlarged the financial capacity of the banks but also adjusted interest rates by controlling bank notes in circulation, dealt with the National Treasury, and discounted bills. In order to let the central bank conduct these activities, the government granted it a monopoly on note issue, taking this privilege away from the national banks. Without the right to issue notes, national banks were no longer different from private banks. The revision of the National Banking Act of 1883 ordered national banks to close their businesses or to transform themselves into private ordinary banks in twenty years. [241]

The Belgian model rather than the decentralized American national banking system seemed to fit the government-led economy, often seen in less developed countries including Japan. The Meiji government, which was seeking the national economic growth to catch up the western countries, was eager to intervene in the economic activity with a centralized financial power. In fact, Masayoshi Matsukata, who assumed office as the Minister of Finance in 1881, initiated the establishment of the Bank of Japan in order 
to settle continuous inflation since the late 1870s. [242] The centralized banking system was considered to be suitable for controlling money supply in the national economy.

In addition to the Bank of Japan, the Meiji government helped establish specialized financial institutions that would support the industrial development policy. In 1879, before the formation of the Bank of Japan, the Yokohama Specie Bank was formed to finance foreign trade by dealing with foreign bills of exchange and documentary bills. While the establishment of the Specie Bank was based on the National Banking Act, which was amended in 1876, the Bank was under the governmental protection. The government financed a third of the capital of the Specie Bank when it was established. Then, it provided the Bank with exchange deposits without interest or with low interest rates. The Specie Bank at once set up branches in London and New York, and then elsewhere as well. [243] Although after 1889, all government deposits were transferred to the Bank of Japan, the Specie Bank was allowed to make a special contract in which the Specie Bank could borrow funds in the form of discounts on foreign bills of exchange with interest of only 2 per cent annually. [244] One of the significant contributions of the Specie Bank was that it facilitated the introduction of foreign capital to Japanese companies. After the Sino-Japanese War, the bank handled the indemnity received from China at its London Branch and used it as exchange funds, which improved international credit toward Japan and in turn led to the adoption of the Gold Standard in 1897. [245]

The Hypothec Bank and the Industrial Bank of Japan were established in 1896 and 1900 respectively in order to provide long-term, low-interest funds to manufacturing industry. The business of the Hypothec Bank was to make real estate mortgage loans to industries. The Industrial Bank was formed to finance industry through collateral loans. 
Apart from collateral loans, the Industrial Bank also played a significant role in importing foreign funds; after the Russo-Japanese War, the bank offered bonds of railroad companies, public bonds, and its own stock in Great Britain and the United States. [246] Along with the development of the banking system, the securities market was also established. Under the Stock Exchange Ordinance of 1878, the Tokyo and Osaka Stock Exchanges were founded in that year. At first the exchanges mostly dealt with Japanese government bonds because there were not so many corporations at that time. However, in 1886 the dealing on corporate securities exceeded those of government bonds, when many modern corporations especially railroad and textile companies appeared. [247] Unlike in the United States in the pre-World War I years, the Stock Exchanges in Japan dealt with stock more than corporate bonds. In fact, while the stocks of many companies, specifically railroad companies, were listed in the Tokyo Stock Exchange during the 1880 and 1914, only two companies listed their bonds: the Hypothec Bank of Japan and the Boso Railroad. [248] Takeo Hoshi attributes the slowness of the development of the Japanese bond market to the adoption of registered bonds; since registered bonds complicated transfers, they were not attractive to investors.[249] Also, the high risk of newly emerging businesses, Hoshi states, hampered the development of the bond market. Before 1920s, foreign capital also contributed to the industrialization in Japan. Although the Meiji Government feared of the semi-colonization of the country when its industries were still immature, foreign capital was gradually introduced in Japan as its demand for foreign capital grew after the victory in the Sino-Japanese War of 1895. At that time, "rising imports of capital equipment and overseas technologies" could not be financed with domestic funds alone. On 17 July 1899, as the first step to capital 
liberalization, the Meiji government guaranteed U.S. citizens exclusive right to trade and to own properties for commercial purposes by the new bilateral accord with the United States. [250] After the victory in Russo-Japanese War of 1904, the expansion of industries, monopoly of Korean markets, and penetration of the open markets in China all further raised the international position of Japanese firms. As a result, some companies could successfully utilize British and U.S. funds. For example, Nippon Electric Company, Ltd. was established with Western Electric's holding (U.S) of 54 per cent of shares in 1899. In 1905 and 1910, General Electric (U.S) entered the joint ventures, obtained Tokyo Electric and Shibaura Engineering respectively. In 1907, The Nihon Steel obtained 50 per cent of its capital from Armstrong and Vickers (U.K) and the Teikoku Filature 60 per cent of capital from J. P. Coats (U.K). [251] Although many other companies were unable to attract foreign capital into their venture (as direct investments) due to their low profitability and low international credit, the government supported some companies by a special law that guaranteed the foreign bonds they issued. [252]

Under the nascent banking system and securities market, Japanese modern business emerged. Although the Japanese financial system was different from the American one, the growth of railroad industry was deeply associated with the development of Japanese financial institutions, as in the American case.

\subsection{Railroad Finance}

Although the government began railroad construction at first, private railroad companies appeared after 1880 . The government took it seriously that railroads were indispensable for industrial development, but it was not able to finance the construction 
of the nation-wide railroad system by itself. In 1872, considering the financial burden of the construction of state-owned railroads, Tomomi Iwakura, a politician of the early Meiji Period, asserted that the only way to construct railroads all over Japan lay in the reliance on private enterprises; they would finance the business by inviting the public to subscribe railroad stocks and pay them dividend. [253]

The capital required for the railroad industry was huge. According to Masaho Noda, the average capital of the major railroad companies was 30 to 75 times as much as that of the other corporations.[254] Yoshiro Miwa and J. Mark Ramseyer also show that in the 1890s average paid-in capital of railroad companies overwhelmed that of the other large industries - electric utilities and cotton spinning. [255] (Table 8)

(in 1000's of Yen)

\begin{tabular}{|l|r|r|r|r|r|}
\hline & \multicolumn{1}{|c|}{1890} & \multicolumn{1}{|c|}{1892} & \multicolumn{1}{|c|}{1894} & \multicolumn{1}{|c|}{1896} & \multicolumn{1}{|c|}{1898} \\
\hline Railroads & 3,253 & 3,711 & 3,034 & 3,383 & 3,665 \\
\hline $\begin{array}{l}\text { Electric } \\
\text { Utilities }\end{array}$ & 168 & 152 & 120 & 145 & 141 \\
\hline $\begin{array}{l}\text { Cotton } \\
\text { Spinning }\end{array}$ & 143 & - & 271 & 379 & 456 \\
\hline
\end{tabular}

Source: Miwa and Ramseyer, "Banks and Economic Growth", p143

Table 8: Paid-in Capital per Firm in Three Major Industries

Most of the capital required was long-term funds since it was mostly used to construct facilities in broad areas. As Iwakura stated, this huge capital requirement was mainly financed by common stock. From 1884 to 1898 , the ratio of common stock to gross assets of the railroad industry was more than 88 per cent. [256]

Despite the importance of common stock, it was not easy to find subscribers to railroad stock in the early years. The public was suspicious of the profitability of the 
business because the railroad industry was quite new and it was the biggest business unprecedented by the public.[257] For that reason, politicians and old feudal lords along the railroad lines often forced local capitalists to subscribe to railroad stock.[258] Also, the government lent support by guarantying dividends, providing subsidies, renting out land gratis, granting tax exemptions, and providing technical support. [259]

The difficulty in distributing stock to the public was not limited to the promotion period for the companies; the high face value of railroad stock hampered new purchases when more capital was needed later. Before 1890, the face value of railroad stock was mostly $¥ 100$. This was too high for the public to afford. Since $150 \mathrm{~kg}$ of rice cost $¥ 7$ in 1880 , $¥ 100$ was equivalent to the value of $2,142.86 \mathrm{~kg}$ of rice, or to 21 years of rice consumption per person at that time. [260] In 1890, according to the Commercial Law, the minimum par value was reduced to $¥ 50$ when the capital was equal or more than $¥ 100,000$, and $¥ 20$ otherwise, but even after the reduction of minimum par value, the high stock price was an obstacle for stock subscription. Therefore, when the companies issued new stock, it was usually allocated to existing shareholders, who were reliable investors with ample funds. In order to attract them, the companies had to provide them with premium through par value issue. [261]

Under such high face value, the installment plan for the payment of stock prices called bunkatsu haraikomi seido, was adopted. When a company sold stock, subscribers paid a portion of share price at that time. The rest was paid in installments, whenever the company asked later on. This method was advantageous both to the company and to the subscribers. While it reduced the financial burden of shareholders, it also diminished the 
dividend payment of the companies by collecting the payment along with the progress of construction. [262]

Another method to facilitate the subscription of stock was the adoption of stock collateral loan [kabushiki tan'po kin'yu]. That is, in order to pay off the installments, shareholders could borrow money from commercial banks by depositing their stock as collateral. In turn, the collateral stock received by the commercial banks was discounted by the central bank, the Bank of Japan. [263]

Along with the installments plan and stock collateral loans, a railroad stock boom in the late 1880 s played a role in distributing railroad stock widely to the public. The prospects of the profitability of the railroad business and the reduction of interest rate as a result of the establishment of modern financial institutions at that time turned many middle-class people to stock speculation. [264] In fact, railroad stock was a major dealing in the Tokyo Stock Exchange; half the amount of stock trade in the Exchange was railroad stock in the late nineteenth century.[265]

Preferred stock was also used in Japanese railroad companies, but similar to American counterparts, they tended to use it mainly during financial reconstruction. This is because the Commercial Law prohibited the use of preferred stock for promotion of the companies. Although preferred stock was sometimes used to refund debt or to redeem bonds with high interest rate, it was mostly used to meet long-term as well as short-term financial needs after the reduction of capital. In particular, medium- and small- sized railroad companies that were more likely to face financial problems relied on it. Due to the difficulties in inviting subscriptions, most of the preferred stock was allocated to existing shareholders. In addition, in order to attract investors who bore the reduced 
dividends and capital under reconstruction, they needed to provide them with preferred right to dividends and to the distribution of remaining properties when the company was in insolvency. [266]

Although the main source of funds in the railroad industry was common stock, the companies also came to rely on bond issues. The use of bonds increased rapidly after the depression of 1890 when the decline of stock prices discouraged people to invest in stock.[267] Unlike stock, however, bonds were not distributed widely to the public. Although banks sometimes invited the public to subscribe to bonds, only a small number of institutional and individual investors held most of them. Since there were no collateral loans before the Railway Collateral Law and the Collateral Bond Trust Law, which were promulgated in 1905, many investors were not willing to buy unsecured bonds. Thus, the lack of the investors often led to the allocation of bonds to major shareholders. [268]

In spite of the huge demand for capital, railroad companies were not eager to rely on foreign capital. One of the reasons was the policy of the exclusion of foreign capital in the early Meiji Period. In 1869, American, A. L. C. Portman, who had been granted a license to build a railroad between Tokyo and Yokohama in the end of the Tokugawa Period, was deprived of it by the Meiji government. Since then, no foreign capital had been introduced to the railroad industry before the Russo-Japanese War of 1905. [269] After the victory in the war, railroad companies took an increasing interest in the introduction of foreign capital along with the industrial development and the rise of the international standing of the nation. After the issuance of the Railway Collateral Law and Collateral Bond Trust Law of 1905, two railroad companies issued foreign collateral bonds [270] In 1906, the Hokkaido Colliery and Railway Co., Ltd issued $£ 1,000,000$ 
15 years 5 per cent collateral bonds, and the Kansei Railway issued $£ 1,000,0004.5$ per cent 20 years collateral bonds.[271] These are the first and the last foreign bond issues in private railroad companies; major railroad companies were nationalized in 1905. [272]

In contrast to the importance of stock in railroad finance, the role of banks was indirect. Banks made stock collateral loan to investors, not direct loans to railroad companies. As Noda explains, a fourth to a third of loans made by ordinary banks were stock collateral loans. To finance these loans, the banks, in turn, received collateral trust loans made by the Bank of Japan. Another role of the banks was the bond-underwriting business, which appeared after the 1890s. [273] For example, the Kyushu Railway, one of the biggest railway companies, issued $¥ 1,500,000$ bonds in 1893 . A syndicate of twenty banks underwrote this issue. [274] Although some banks owned stock of railroad companies, banks' ownership did not usually mean bankers' control over the railroad management. The railroad companies' financial demands were so huge that the ownership was not concentrated on a bank. Unlike main banks in post-World War II Japan, banks at that time were not able to control railroad companies through ownership and did not make any industrial loans. Rather, the banks indirectly contributed to corporate finance in the industry as supporters of the securities market.

Thus, railroad finance in Japan was based on equity finance not bank loans. Since stock was widely held in the public, no shareholders had control power. On the other hand, since the role of the bank was indirect, bankers' influence on management was limited, too. As Chapter 1 explained, American railroad finance heavily relied on bond issues, and railroad stock was not widely distributed in the public. This does not fit the American model of corporate finance. Rather, Japanese railroad finance characterized by 
the reliance on equity finance and widely distributed stock, seemed much closer to the American model than the Japanese one.

\subsubsection{Corporate Finance in the Nihon Railway}

The Nihon Railway was the first private railroad in Japan. It was established in 1881 with the capitalization of $¥ 20$ million to connect Tokyo through Takasaki to Aomori, the northern end of the main land of Japan. Considering that the capital of average corporation in Japan was about $¥ 100,000$, the size of the company was remarkable. The major promoters of the company included descendants of samurai (the warrior class) such as Kentoku Hayashi and Tadanobu Otaguro, government officials such as Yasukazu Yasuba, and the nobility led by Tomomi Iwakura. These promoters were, however, not able to meet a huge financial demand of the company. They subscribed about 30 per cent of stock only. Besides, by adapting the installment plan, what they paid at first was just a fifth of their total payment. [275]

Facing the financial difficulty, the Nihon Railway relied on the government in its early years. To facilitate the sales of the stock, the government guaranteed 8 per cent of dividend for the company's stock until the construction of each section was completed.[276] As a result, the section between Tokyo and Sendai received the interest subsidy for ten years and the section between Sendai and Aomori for fifteen years. [277] Under the governmental support, even when the ratio of net income to capital was lower than 8 per cent, the company offered equal to or more than 8 per cent of dividends in many years. (Table 9) Although the guarantee of interest was not always incentive enough to attract investors, it certainly raised the value of investment in the stock. [278] 
The government also made loans to the Nihon Railway. In 1881, the company borrowed silver of $¥ 857,000$ from the Ministry of Public Works (Kobu-sho) to purchase foreign products. [279] In 1882, it asked the Ministry of Finance (Okura-sho) to make a loan and received $¥ 300,000$. In that year, the company also obtained $¥ 121,508$ from promoters, which was equivalent to a fifth of their total subscription of the stock, and the first installment payment amounting to $¥ 436,290$ from investors, but the sum of the two was far below the amount the company needed. [280]

\begin{tabular}{|r|r|r|}
\hline Year & $\begin{array}{c}\text { Net Income to } \\
\text { Capital }\end{array}$ & Dividends \\
\hline 1883 & $9.0 \%$ & $10.0 \%$ \\
\hline 1884 & $7.1 \%$ & $10.0 \%$ \\
\hline 1885 & $6.1 \%$ & $8.5 \%$ \\
\hline 1886 & $6.2 \%$ & $9.0 \%$ \\
\hline 1887 & $9.4 \%$ & $10.0 \%$ \\
\hline 1888 & $9.5 \%$ & $12.0 \%$ \\
\hline 1889 & $6.8 \%$ & $11.0 \%$ \\
\hline 1890 & $5.5 \%$ & $10.0 \%$ \\
\hline 1891 & $6.6 \%$ & $10.0 \%$ \\
\hline 1892 & $9.4 \%$ & $10.0 \%$ \\
\hline 1893 & $10.3 \%$ & $10.0 \%$ \\
\hline 1894 & $10.1 \%$ & $10.0 \%$ \\
\hline 1895 & $10.1 \%$ & $10.0 \%$ \\
\hline 1896 & $8.8 \%$ & $11.0 \%$ \\
\hline 1897 & $8.7 \%$ & $10.0 \%$ \\
\hline 1898 & $7.4 \%$ & $8.5 \%$ \\
\hline 1899 & $11.1 \%$ & $10.0 \%$ \\
\hline 1900 & $12.0 \%$ & $10.0 \%$ \\
\hline 1901 & $12.6 \%$ & $10.0 \%$ \\
\hline 1902 & $12.5 \%$ & $11.0 \%$ \\
\hline 1903 & $13.5 \%$ & $11.0 \%$ \\
\hline 1904 & $13.6 \%$ & $11.0 \%$ \\
\hline 1905 & $16.9 \%$ & $13.0 \%$ \\
\hline & $\mathrm{S} \%$ & \\
\hline & & 1 \\
\hline
\end{tabular}

Source: Nakamura, p iii.

Table 9: The Ratio of Net Income to Common stock and Dividend Rate of the Nihon Railway 
Furthermore, the government provided land grants, tax exemptions and construction support. [281] In 1881, the government sold the first national railway established between Tokyo and Yokohama to the Nihon Railway. The contract states that the land used for tracks, buildings, and parking lots for rolling stock should not be taxed.[282] Also, new construction was carried out by the Ministry of Public Works because the company did not have qualified technicians and equipments for construction.[283] As Noda explains, these governmental supports aimed at the concentration of capital to strengthen the national economy and at the protection of the wealth of the nobility who were the major financiers of the company. [284]

As a private company, the Nihon Railway also made efforts to raise funds itself, but the sale of the stock was not easy at first. The public was suspicious of its unprecedented scale of the business. [285] The government officials such as Tomomi Iwakura invited the subscriptions of the stock to the nobility with considerable effort. Local officials also attempted to persuade local capitalists to make investments in the company. As a result, the company managed to secure 889 shareholders. [286]

The company expanded its size rapidly after its promotion period. Gross assets of the company in 1882 were $¥ 2$ million. It increased to more than $¥ 20$ million in 1892 , and reached $¥ 66.9$ million before the nationalization. [287] Most of the assets the company held were long-term assets, which included railroad tracks, rolling stock, other construction, equipments, and land. The proportion of long-term assets to gross assets was high. Especially, after 1890 when the business became stabilized, it mostly marked more than 80 per cent. [288] 
The huge gross assets were mostly financed by common stock after the repayment of the loans from the government in 1882 . The ratio of paid-in capital to gross assets after 1883 market between 78.3 per cent to 94.6 per cent. Other financial sources than stock was negligible. (Table 10)

(in 1000's of yen)

\begin{tabular}{|r|r|r|r|}
\hline Year & Gross Assets & \multicolumn{2}{|c|}{ Paid-in Capital } \\
\hline 1882 & 1,951 & 686 & $(35.2 \%)$ \\
\hline 1883 & 3,109 & 2,435 & $(78.3 \%)$ \\
\hline 1884 & 4,370 & 4,058 & $(92.9 \%)$ \\
\hline 1885 & 6,330 & 5,960 & $(94.2 \%)$ \\
\hline 1886 & 7,913 & 7,353 & $(92.9 \%)$ \\
\hline 1887 & 9,889 & 8,772 & $(88.7 \%)$ \\
\hline 1888 & 12,632 & 11,454 & $(90.7 \%)$ \\
\hline 1889 & 16,439 & 14,824 & $(90.2 \%)$ \\
\hline 1890 & 19,034 & 16,970 & $(89.2 \%)$ \\
\hline 1891 & 19,025 & 17,994 & $(94.6 \%)$ \\
\hline 1892 & 21,550 & 19,197 & $(89.1 \%)$ \\
\hline 1893 & 22,034 & 19,200 & $(87.1 \%)$ \\
\hline 1894 & 26,315 & 22,587 & $(85.8 \%)$ \\
\hline 1895 & 31,101 & 26,985 & $(86.8 \%)$ \\
\hline 1896 & 35,368 & 31,182 & $(88.2 \%)$ \\
\hline 1897 & 44,779 & 40,258 & $(89.9 \%)$ \\
\hline 1898 & 49,472 & 44,700 & $(90.4 \%)$ \\
\hline 1899 & 50,490 & 44,700 & $(88.5 \%)$ \\
\hline 1900 & 51,899 & 45,300 & $(87.3 \%)$ \\
\hline 1901 & 53,542 & 45,900 & $(85.7 \%)$ \\
\hline 1902 & 54,882 & 46,500 & $(84.7 \%)$ \\
\hline 1903 & 56,442 & 46,500 & $(82.4 \%)$ \\
\hline 1904 & 59,314 & 48,060 & $(81.0 \%)$ \\
\hline 1905 & 64,019 & 50,400 & $(78.7 \%)$ \\
\hline
\end{tabular}

Source: Eigyo Hokokusho

*Gross assets do not include unpaid capital.

Table 10: Equity Finance of the Nihon Railway

Along with the progress of construction, the initial capital stock of $¥ 20$ million was offered in 5 calls in 1882, 1885, 1888, 1890, and 1892. To facilitate the sale of the 
stock in each issue, the Nihon Railway adopted installment plans. For example, according to the annual reports, the issue of 1882,1885 , and 1888 of the stock adopted twelve times installments. When the payments of installments were not made, the unpaid stock was often offered to the public.[289] After paid-in capital reached to the amount of total capitalization, the company increased total capitalization to $¥ 30$ million in 1893 , to $¥ 40$ million in 1896, and to ¥66 million in 1897 in order to construct branch tracks and to acquire the Ryomo Railways. [290]

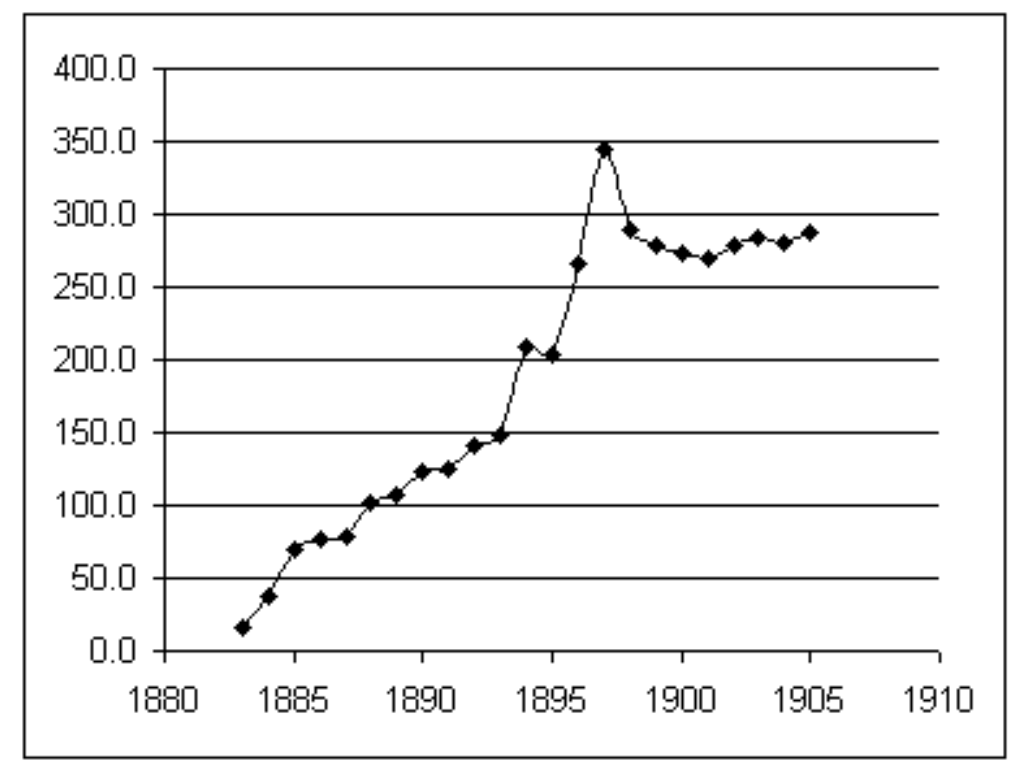

Source: Eigyo Hokokusho

Figure 14: The Average Number of Shares per Shareholder in the Nihon Railway

Most of the stock newly issued was allocated to existing shareholders, which led to the concentration of stock ownership. Shares increased from 119,314 to $1,320,000$ or by 1,200,686 between 1884 and 1897, while the number of shareholders decreased from 4,138 to 3,826 . As a result, the average number of shares held by per shareholder soared from 28.8 shares in 1884 to 386 in 1897. [291] After 1897, the number of shareholders 
increased and the average shareholding decreased, but the stock was never widely dispersed in the public. (Figure 14) In fact, Yutaka Katakura explains that the existing shareholders of the company did not sell the stock to other investors for two reasons. First, the stock promised high dividend income and was regarded as safer than bank deposits. Second, since the company offered new stock to the existing shareholders at face value, which was lower than the market price, the existing shareholders were willing to hold the old stock to receive new stock allocations. [292] Thus, the slow increase in the number of shareholders and the shareholders' willingness to hold the stock meant that shareholding of the company was less widely distributed in the public than other major railroad companies.

Throughout the years from the establishment to the nationalization of the Nihon Railway, the biggest shareholders in the company were the nobility, in particular the ones who belong to the Fifteenth National Bank and the Mitsubishi group. The number of the shares the Fifteenth Bank held in total was overwhelming. It amounted to 22 to 28 per cent of the total number of stock from 1881 to 1906. [293] The purpose of the Bank to hold the stock on behalf was to grasp the control of the management at first. In 1898, however, the decline of profits and the confusion of management of the company led to the change of corporate governance; the Fifteenth Bank reduced the number of officials on the Board, while maintaining the ownership of the company. [294] In other words, it continued to own the stock for the profit from dividends and capital gains rather than control.

To a lesser extent, the Mitsubishi group also contributed in the subscription of the stock. Hisaya and Yanosuke Iwasaki, the leaders of the Mitsubishi Goshi Ltd. were 
among the ten biggest shareholders of the company. The director of Mitsubishi Goshi, Yoshimasa Ono was also a major investor. Based on the ownership, Mitsubishi group could influence the management of the company; it could send three directors to the executive committee in 1891 and 1892, Ono became the president of the company. However, their ownership and managerial power was overwhelmed by the Fifteenth Bank. Stock ownership of Hisaya and Yanosuke Iwasaki accounted for only a few per cent of the total shares. [295] (Table 11)

\begin{tabular}{|c|c|c|c|c|c|c|c|c|}
\hline Shareholders & \multicolumn{2}{|c|}{1894.6} & \multicolumn{2}{|c|}{1898.6} & \multicolumn{2}{|c|}{1901.6} & \multicolumn{2}{|c|}{1905.8} \\
\hline $\begin{array}{l}\text { The Fifteenth } \\
\text { Bank }\end{array}$ & 171,852 & (28.6\%) & 305,732 & (23.2\%) & 305223 & (23.1\%) & 294,463 & (22.3\%) \\
\hline The Iwasaki's & 19,297 & $(3.2 \%)$ & 36,717 & $(2.8 \%)$ & 33482 & $(2.5 \%)$ & 33,482 & $(2.5 \%)$ \\
\hline Total shares & 600,000 & $(100 \%)$ & $1,320,000$ & $(100 \%)$ & $1,320,000$ & $(100 \%)$ & $1,320,000$ & $(100 \%)$ \\
\hline
\end{tabular}

Source: Nakamura, p. xi, Table2

*Per centages shown in parenthesis are the ratios of the shareholding to total shares.

Table 11: The Number of Shares held by the Major Shareholders

In contrast to stock, the Nihon Railway used bonds only once. While major railways usually issued bonds to meet financial needs during recessions, the Nihon Railway used bonds when it attempted to acquire the Mito Railway. In 1891, it issued the $¥ 810,0006$ per cent, 21 years bonds.[296] This issue was subscribed by the Mito Railway itself, through which the Nihon Railway paid interest of the bonds from the profit of the Mito Railway in order to reduce the effect of the large bond issue on its shareholders.[297]

The role of banks in the Nihon Railway was limited. Although the Fifteenth Bank was the biggest shareholder of the company, it never owned the majority of the stock, and its control power declined after 1898 due to the decrease in profits under its management 
and managerial confusion. The bank also did not make any long-term loans for the company. It was only negligible amounts of short-term loans that appeared in to the annual reports of the company. Rather, as Noda explains, the major role of the banks seemed to make collateral loans to investors.

In the United States, private bankers had played a significant role in financing the expansion of the railroad industry by underwriting railroad bonds since 1880 . Their financial contribution in the industry helped develop the American economy on the whole and shift the United States from agricultural to industrial society. On the other hand, in Japan, the nobility class and warriors in the feudal society came to be leading businessmen and capital-rich investors under government favoritism in the Meiji period. Their active part in business as a new economic entity drove the transformation from feudal society to industrial society in Japan.

In 1906, as mentioned above, under the Railway Nationalization Law all railways except the ones to serve local transportation were nationalized.[298] As railroad stocks disappeared as a result of nationalization, investors began to turn from railroads to electric utilities. Electric utility stock was suitable for investment; as a public utility, the stable growth of the business was promised by the increase in the demand as the economy grew.

\subsection{Public Utility Finance-Electric Utilities}

\subsubsection{Electric Utility Finance before World War I}

The electric utility industry grew in size rapidly after 1880 . The paid-in capital in the industry was only $¥ 200,000$ in 1886 , but increased to $¥ 87.7$ million after RussoJapanese War of 1907 , and to $¥ 762.1$ million after World War I. Then, it reached 
$¥ 3,180.8$ million in 1930 . The growing business required long-term funds because electric utility companies needed to construct facilities to generate and transmit electric power. These facilities have to be big enough to meet the demand for electricity at the peak, since electricity was not a storable product. [299] In spite of the demand for huge funds, unlike railways, the government did not provide the companies with any supports or protection; they were privately operated enterprises from the beginning. [300]

(in Yen)

\begin{tabular}{|c|r|r|r|}
\hline & $\begin{array}{c}\text { Paid-in Capital } \\
\text { A }\end{array}$ & $\begin{array}{c}\text { Bonds and Loans } \\
\text { B }\end{array}$ & $\begin{array}{c}\text { Debt-to Equity Rate } \\
\text { B/A }\end{array}$ \\
\hline 1903 & $24,101,894$ & $1,806,678$ & $7.5 \%$ \\
\hline 1904 & $35,405,006$ & $2,054,167$ & $5.8 \%$ \\
\hline 1905 & $43,793,077$ & $2,516,700$ & $5.7 \%$ \\
\hline 1906 & $63,386,268$ & $2,636,115$ & $4.2 \%$ \\
\hline 1907 & $87,685,443$ & $5,681,713$ & $6.5 \%$ \\
\hline 1908 & $104,998,339$ & $8,924,278$ & $8.5 \%$ \\
\hline 1909 & $120,422,539$ & $14,886,108$ & $12.4 \%$ \\
\hline 1910 & $169,201,354$ & $23,993,264$ & $14.2 \%$ \\
\hline 1911 & $243,458,276$ & $37,536,645$ & $18.4 \%$ \\
\hline 1912 & $286,634,539$ & $51,985,391$ & $20.0 \%$ \\
\hline 1913 & $397,780,115$ & $79,388,413$ & $21.4 \%$ \\
\hline 1914 & $460,355,240$ & $98,697,414$ & Table \\
\hline
\end{tabular}

Source: Denki Jigyo Kyokai, Denki Jigyo Yoran, p402, Table 52.

Table 12: Equity and Debts in the Electric Utility Industry

The huge financial needs in the industry were mainly met by selling shares of stock before World War I. Miwa and Ramseyer show that in 1910 it was 83 per cent.[301] Similarly, the debt-to-equity ratio reveals the importance of stock. As Table 12 shows, from 1903 to 1914 , the role of stock relative to bonds and loans in electric utility finance gradually decreased, but stock continued to be a major financial source.

Despite huge amounts of stock issued in the industry, the shares were not widely held by the public at first. As with the railroads, when electric utility companies were 
promoted, stock was usually sold to descendants of samurai, and the nobility, national banks, rich merchants, and powerful local politicians. [302] When the companies attempted to increase capitalization, most of the new stock was allocated to the existing stockholders, at least before 1903.

After the Russo-Japanese War, utility stocks for the first time came to be widely distributed in the public. This transformation is in part explained by the huge idle capital brought about through the nationalization of railroads in 1906 and in part by technological progress. As companies facilitated the use of hydro-electric power instead of thermal power, they needed much more capital to build hydro-electric facilities. Thus, the growing financial need had them rely on the general public. [303]

In contrast to stock, bonds were not important financial sources before World War I. Before the Russo-Japanese War, they accounted for only 2 per cent of gross assets.[304] Even after the legal framework to issue collateral bonds were prepared through the issue of Collateral Bond Trust Law, bonds were less important. Bond issues accounted for only 8.6 per cent of the increase in capital from 1907 to 1914.[305] In fact, there were no major companies that used bonds, except the Ujikawa Electric Company before World War I. [306] Also, no foreign bonds were issued before World War I in the industry. Indeed, the Tokyo Electric Light and the Osaka Electric Light Companies were planning to issue foreign bonds in the early twentieth century, but all failed.

Similar to railroad finance, the role of banks in electric utility finance was limited before World War I. According to Takeo Kikkawa, bank loans accounted for 8 per cent of the increase in capital from 1893 to 1903 and 13 per cent from 1904 to 1914. [307] Banks contributed to corporate finance indirectly through collateral stock loans. For 
example, the Mitsui Bank accepted stock of major electric companies as collateral. Those electric power companies included Tokyo, Yokohama Kyodo, Nagoya, Kobe, Osaka, Kyoto and Hiroshima Electric Light Companies. [308] Also, since bonds were not an important financial source in the industry, banks' role as underwriters and trustees was not significant. In fact, most of the bonds issued in the industry were not underwritten. By law, only the Industrial Bank could act as trustee for bonds. [309]

\subsubsection{Electric Utility Finance from World War I to 1930}

Corporate financial practices in electric utility companies were radically changed after World War I. In spite of the rapid increase in capital stock, the importance of capital stock gradually declined. The ratio of capital stock to total fixed capital accounts for 67.8 per cent from 1915 to $1919,61.2$ per cent from 1920 to 1924 , and 37.4 per cent from 1925 to $1930 .[310]$ Instead of capital stock, the role of bonds increased rapidly in the 1920s. The ratio of bonds to the increase in total fixed capital rose from 15.1 per cent between 1915 and 1919 through 28.1 per cent between 1920 and 1924 to 42.5 per cent between 1925 and 1930. Kikkawa explained the reasons that led the companies to bond issues. First, in the 1920s, the use of bonds was more cost-effective than that of stock. While interest rates lowered to 6 to 7 per cent, dividends were around 10 per cent at that time. Second, it was the beginning of the 1920s that the bonds market was firmly established in Japan. Third, bond issues were suitable for meeting the exceptionally huge demand for capital of the growing industry. Finally, the stable growth of the business constantly required capital from bond markets. [311] (Table 13)

More important, the electric utility industry turned to the use of foreign bonds in the 1920s. It began with the Sterling bond issue of the Tokyo Electric Light Company in 
1923 and ended with dollar bond issue of the Taiwan Electric Power in 1931. In total, foreign bonds were issued in the industry sixteen times, amounting to ¥523 million during the years. The issues of foreign bonds in the industry were huge. (Table 14) In 1929, Harumi Matsushima states, foreign corporate bonds in the industry reached 76 per cent of all of the foreign corporate bonds in Japan, and more than 40 per cent of the bonds issued by the electric utility industry were foreign bonds.[312]

(in Yen)

\begin{tabular}{|l|c|c|c|c|c|}
\hline & Stock & Bonds & Loans & Reserves & Total \\
\hline $\begin{array}{l}1915- \\
1919\end{array}$ & $205,450(67.8 \%)$ & $45,747(15.1 \%)$ & $29,251(9.7 \%)$ & $22,619(7.5 \%)$ & 303,067 \\
\hline $\begin{array}{l}1920- \\
1924\end{array}$ & $1,013,196(61.2 \%)$ & $464,980(28.1 \%)$ & $137,647(8.3 \%)$ & $40,437(2.4 \%)$ & $1,656,260$ \\
\hline $\begin{array}{l}1925- \\
1930\end{array}$ & $806,784(37.4 \%)$ & $917,528(42.5 \%)$ & $359,425(16.7 \%)$ & $74,354(3.4 \%)$ & 2158091 \\
\hline
\end{tabular}

Source: Kikkawa, pp22-23

Table 13: The Increase in Long-Term Finance of the Electric Utility Industry

Foreign bonds in electric utility companies were mostly underwritten by British and American investment bankers. Although not quantitatively important in the foreign securities market, these bonds were ranked as high as German bonds. By dealing with them, some investment bankers made sizeable profits. Especially, after the late 1920s when the top investment bankers such as J. P Morgan \& Co and Dillon Read \& Co were cautious of excessive amounts of foreign bond issues, middle class bankers including Guaranty \& Co., and Harris, Forbes \& Co. actively involved in the underwriting business.[313] (Table 14)

The use of foreign bonds was advantageous to electric utility companies. The maturity periods of foreign bonds were usually much longer than those of domestic bonds. 
While maturities of domestic bonds were two to seven years, those of foreign bonds were usually more than twenty years. (Table 14) Also, companies sought exchange gains from

\begin{tabular}{|l|r|r|r|r|r|l|l|}
\hline $\begin{array}{l}\text { Name of } \\
\text { Companies }\end{array}$ & Year & $\begin{array}{l}\text { Amount of } \\
\text { issues } \\
\text { Yen) }\end{array}$ & $\begin{array}{l}\text { Interest } \\
(\%)\end{array}$ & $\begin{array}{l}\text { Issue } \\
\text { Price } \\
\text { (Yen) }\end{array}$ & $\begin{array}{l}\text { Maturity } \\
\text { (Years) }\end{array}$ & Underwriters & Trustees \\
\hline $\begin{array}{l}\text { Tokyo Electric } \\
\text { Light }\end{array}$ & 1923 & $3,000,000$ & 6 & 94 & 25 & $\begin{array}{l}\text { Whitehall } \\
\text { Trust }\end{array}$ & \\
\hline $\begin{array}{l}\text { Daido Electric } \\
\text { Power }\end{array}$ & 1924 & $15,000,000$ & 7 & $911 / 2$ & 20 & Dillon Read & $\begin{array}{l}\text { Industrial } \\
\text { Bank }\end{array}$ \\
\hline $\begin{array}{l}\text { Tokyo Electric } \\
\text { Light }\end{array}$ & 1925 & 600,000 & 6 & 82 & 23 & $\begin{array}{l}\text { Whitehall } \\
\text { Trust }\end{array}$ & \\
\hline $\begin{array}{l}\text { Ujikawa } \\
\text { Electric Power }\end{array}$ & 1925 & $14,000,000$ & 7 & 91 & 20 & $\begin{array}{l}\text { Lee, } \\
\text { Higginson }\end{array}$ & $\begin{array}{l}\text { Industrial } \\
\text { Bank }\end{array}$ \\
\hline $\begin{array}{l}\text { Toho Electric } \\
\text { Power }\end{array}$ & 1925 & $15,000,000$ & 7 & $901 / 2$ & 30 & Guaranty & $\begin{array}{l}\text { Mitsui } \\
\text { Bank }\end{array}$ \\
\hline $\begin{array}{l}\text { Daido Electric } \\
\text { Power }\end{array}$ & 1925 & $13,500,000$ & 6.5 & 86 & 25 & Dillon Read & $\begin{array}{l}\text { Industrial } \\
\text { Bank }\end{array}$ \\
\hline $\begin{array}{l}\text { Toho Electric } \\
\text { Power }\end{array}$ & 1925 & 300,000 & 5 & 97 & 20 & $\begin{array}{l}\text { Prudential } \\
\text { Life }\end{array}$ & $\begin{array}{l}\text { Mitsui } \\
\text { Trust }\end{array}$ \\
\hline $\begin{array}{l}\text { Tokyo Electric } \\
\text { Light }\end{array}$ & 1925 & $24,000,000$ & 6 & $987 / 8$ & 3 & Guaranty & \\
\hline $\begin{array}{l}\text { Toho Electric } \\
\text { Power }\end{array}$ & 1926 & $10,000,000$ & 6 & $981 / 2$ & 3 & Guaranty & \\
\hline $\begin{array}{l}\text { Shinetsu } \\
\text { Electric Power }\end{array}$ & 1927 & $7,650,000$ & 6.5 & $931 / 4$ & 25 & Dillon Read & $\begin{array}{l}\text { Mitsui } \\
\text { Trust }\end{array}$ \\
\hline $\begin{array}{l}\text { Nihon Electric } \\
\text { Power }\end{array}$ & 1928 & $9,000,000$ & 6.5 & 94 & 25 & $\begin{array}{l}\text { Harris, } \\
\text { Forbes }\end{array}$ & $\begin{array}{l}\text { Mitsui } \\
\text { Bank }\end{array}$ \\
\hline $\begin{array}{l}\text { Tokyo Electric } \\
\text { Light }\end{array}$ & 1928 & $70,000,000$ & 6 & $901 / 2$ & 25 & Guaranty & $\begin{array}{l}\text { Mitsui } \\
\text { Bank }\end{array}$ \\
\hline $\begin{array}{l}\text { Tokyo Electric } \\
\text { Light }\end{array}$ & 1928 & $4,500,000$ & 6 & 90 & 25 & $\begin{array}{l}\text { Lazard } \\
\text { Brothers }\end{array}$ & $\begin{array}{l}\text { Mitsui } \\
\text { Bank }\end{array}$ \\
\hline $\begin{array}{l}\text { Toho Electric } \\
\text { Power }\end{array}$ & 1929 & $11,450,000$ & 6 & $961 / 4$ & 3 & Guaranty & \\
\hline
\end{tabular}

Source: Japan Industrial Bank, Nihon Gaisai Shoshi, Shasai Ichiran

* The foreign bonds were denominated in dollars or pound sterling.

Table 14: Foreign Bond Issues of the Electric Utility Companies

yen revaluation through foreign bond issues. Since most of foreign bonds were issued when yen was devalued, the companies expected the profits from the revaluation of yen.[314] The boom of foreign bonds issue was further facilitated by the revision of the Commercial Laws in 1927; it increased the upper limit of bonds issue from the amount 
equivalent to paid-in capital to twice the amount of paid-in capital. [315] Meanwhile, lower interest rate of foreign bonds than that of domestic bonds was not a motivation for the companies to turn to foreign bond issues. The advantage of low interest rate was offset by the low issue price of foreign bonds. (Table 14)

As the role of bonds in electric utility finance increased, banks helped the companies issue bonds more than before. Major banks such as the Mitsui Bank, the Mitsubishi Bank, the Yasuda Bank, the Sumitomo Bank, the Daiichi Bank, and the Industrial Bank, began to underwrite domestic bonds from the 1920s. During the financial depression of 1927, Kikkawa states, the six banks underwrote more than half the bonds issued in the industry. [316]

Despite risk and financial burden of underwriting business, these underwriting banks tended to avoid forming syndicates during the 1920s. [317] Their avoidance of syndicates is in part explained by the banks' intention to construct strong ties to electric companies. In fact, particular relationships between banks and the companies existed in the 1920s; the Mitsui Bank tied with the Tokyo Electric Light and the Toho Electric Power, the Mitsubishi Bank with the Daido Electric Power, the Sumitomo Bank with the Ujikawa Electric, the Yasuda Bank with the Tokyo Electric Power, the Daiichi Bank with the Kyoto Electric Power, and the Industrial Bank with the Daido Electric Power. [318] In addition, banks facilitated collateral bonds issues as trustees. Especially the Mitsui Bank and the Industrial Bank dealt with more than 60 per cent of the entire electric utility collateral bonds. Also, only the two banks were allowed to be trustees of collateral on foreign bonds. [319] When the Industrial Bank was established, the Meiji government decided on its policy that private companies should use the Industrial Bank 
as a trustee as much as possible when they issued foreign bonds. With this policy, the government attempted to prevent private companies from tying into foreign capital market directly, fearing that scattering importations of foreign capital would harm the credit in Japanese economy. [320] Meanwhile, the participation of the Mitsui bank in trusteeship of foreign bond issue began after 1925. Although foreign bond issues were numerous in the 1920s, the Mitsui Bank was only one ordinary bank that was allowed to deal with the trust business due to its credit standing in foreign countries. [321]

The role of banks as supporters of the bond market came to be important, but their financial role was not the same as that of post-war main banks. While banks tried to create close ties with the companies, they were not eager to own the stock. Rather, similar to foreign investment bankers, they attempted to obtain control power as underwriters and trustees. These financial features are examined in the case of the Tokyo Electric Light Company, the first electric light company in Japan.

\subsubsection{Tokyo Electric Light Company}

\subsubsection{Corporate Finance before World War I}

The Tokyo Electric Light Company was established in 1883 with the capitalization of $¥ 200,000$. It was the first company to supply electricity to the public in Japan. The promoters of the company were the people in financial circles such as Eiichi Shibusawa, Sakuro Yajima, Kihachiro Okura, and Rokuro Hara. [322] These promoters at first subscribed $¥ 50,000$ of the stock, and planned to sell the rest to the public. It was, however, difficult to distribute the stock because of the recession of 1882 and the immature state of the banking system at that time. As Toyo Kurihara argues, Masayoshi Matsukata, the Minister of Finance, carried out the deflation policy against the issue of 
huge amounts of inconvertible notes in the 1870s. At the same time, the recession in many countries led to the decrease in the exports of raw cotton from Japan. These circumstances resulted in the deep depression in Japan. On the other hand, Japan did not accumulate capital enough to finance big business. Without sufficient funds, national banks managed to finance the business only by using the privilege to issue bank notes. It was after 1882 when the Bank of Japan was established that the investors were eager to subscribe the company's stock by utilizing stock collateral loans. These investors were the nobility, government merchant, and local capitalists. [323]

Although the scale of the business of the Tokyo Electric Light Company was smaller than that of major railroads at first, it expanded rapidly. While the amount of gross assets in the Nihon Railway were $¥ 2$ million in 1892 , that of the Tokyo Electric light was only $¥ 167,884$ in 1887 . However, the company grew rapidly as the demand for electricity increased. The number of electric lights sold by the company surged from 138 in 1888 to more than 1.5 million in1914. The use of electric power also increased 30KW in 1899 to more than $28,000 \mathrm{KW}$ in 1914 . To meet the increasing demand, the company grew one of the biggest businesses with gross assets of more than $¥ 50$ million before World War I. [324]The growing company required a huge amount of capital. Gross assets of the company increased from $¥ 167,884$ in 1887 to $¥ 54,420,352$ in 1914 , although temporary decreasing in 1891. [325]

Long-term assets including construction accounts and securities of other companies to gross assets accounted for 86.3 per cent of gross assets in average from 1887 to 1914 . This financial need was met mainly by stock. [326] Along with the expansion of business, paid-in capital grew from $¥ 122,000$ in 1887 to $¥ 39,601,560$ in 
1914. As Table 15 shows, from 1887 to $1914,72.8$ to 91.6 per cent of financial needs were met by common stock. (Table 15)

(in Yen)

\begin{tabular}{|r|c|r|r|r|r|}
\hline & $\begin{array}{c}\mathrm{A} \\
\text { Gross Assets }\end{array}$ & $\begin{array}{c}\mathrm{B} \\
\text { Stock }\end{array}$ & \multicolumn{1}{c|}{$\mathrm{B} / \mathrm{A}$} & \multicolumn{1}{c|}{$\mathrm{C}$} & $\mathrm{C} / \mathrm{A}$ \\
\hline 1887 & 167,884 & 122,000 & $72.7 \%$ & 0 & \\
\hline 1888 & 361,939 & 300,000 & $82.9 \%$ & 20,546 & $5.7 \%$ \\
\hline 1889 & 463,795 & 425,000 & $91.6 \%$ & 0 & \\
\hline 1890 & 791,321 & 604,000 & $76.3 \%$ & 60,099 & $7.6 \%$ \\
\hline 1891 & 748,968 & 668,510 & $89.3 \%$ & 0 & \\
\hline 1892 & 797,731 & 668,520 & $83.8 \%$ & 0 & \\
\hline 1893 & 866,181 & 784,955 & $90.6 \%$ & 0 & \\
\hline 1894 & 952,478 & 817,865 & $85.9 \%$ & 0 & \\
\hline 1895 & $1,173,317$ & 999,705 & $85.2 \%$ & 0 & \\
\hline 1896 & $1,627,596$ & $1,295,935$ & $79.6 \%$ & & 0 \\
\hline 1897 & $2,225,095$ & $1,700,000$ & $76.4 \%$ & 270,000 & $12.1 \%$ \\
\hline 1898 & $2,500,997$ & $1,991,365$ & $79.6 \%$ & 216,000 & $8.6 \%$ \\
\hline 1899 & $2,652,046$ & $2,375,000$ & $89.6 \%$ & 30,000 & $1.1 \%$ \\
\hline 1900 & $2,901,266$ & $2,375,000$ & $81.9 \%$ & 286,000 & $9.9 \%$ \\
\hline 1901 & $3,049,423$ & $2,600,000$ & $85.3 \%$ & 181,832 & $6.0 \%$ \\
\hline 1902 & $3,715,016$ & $2,897,655$ & $78.0 \%$ & 300,000 & $8.1 \%$ \\
\hline 1903 & $4,153,270$ & $3,200,000$ & $77.0 \%$ & 533,087 & $12.8 \%$ \\
\hline 1904 & $5,558,803$ & $4,375,000$ & $78.7 \%$ & 656,403 & $11.8 \%$ \\
\hline 1905 & $7,374,554$ & $5,050,000$ & $68.5 \%$ & $1,671,812$ & $22.7 \%$ \\
\hline 1906 & $10,584,827$ & $7,150,000$ & $67.5 \%$ & $2,675,000$ & $25.3 \%$ \\
\hline 1907 & $17,371,619$ & $13,873,635$ & $79.9 \%$ & $1,370,000$ & $7.9 \%$ \\
\hline 1908 & $20,917,552$ & $17,260,000$ & $82.5 \%$ & $1,208,952$ & $5.8 \%$ \\
\hline 1909 & $21,853,900$ & $17,260,000$ & $79.0 \%$ & $1,727,329$ & $7.9 \%$ \\
\hline 1910 & $29,140,729$ & $24,000,000$ & $82.4 \%$ & 178,507 & $0.6 \%$ \\
\hline 1911 & $34,770,730$ & $30,500,000$ & $87.7 \%$ & 150,700 & $0.4 \%$ \\
\hline 1912 & $44,339,411$ & $34,400,000$ & $77.6 \%$ & $5,387,492$ & $12.2 \%$ \\
\hline 1913 & $50,109,399$ & $39,595,825$ & $79.0 \%$ & $5,609,274$ & $11.2 \%$ \\
\hline 1914 & $54,420,352$ & $39,601,560$ & $72.8 \%$ & $10,213,576$ & $18.8 \%$ \\
\hline & & & & 0 & 0 \\
\hline
\end{tabular}

Source: Nitta, Appendix 1

*Loans do not include bonds.

Table 15: Long-Term Finance of the Tokyo Electric Light Company 
Similar to railroads, the stock issues of the company were closely related to the collateral trust loans and the installment plan. These financial practices helped shareholders finance the payments of the high face value of the stock from the first year, According to the Article of Association, shareholders were required to pay 20 per cent of stock price at first and then to pay the rest in five times. [327] When the amount of paidin capital came to be close to that of authorized capital, the company increased capitalization and used the installment plan again. The installments were often paid through stock collateral loans. Although it is difficult to trace the movement of funds from banks through individuals to companies, the use of collateral stock loans was an essential financial method. As Kikkawa argues, the majority of collaterals for loans made by Mitsui Bank were stock. [328]

Compared with railroads, the stock of the company was less dispersed. After the Russo-Japanese War, considering the number of shareholders jumped up from 64 in 1882 to more than 3,000 in 1911, and the stock seemed distributed widely. However, the average number of shares per shareholder increased from 62.5 shares in 1882 to 322.1 shares in 1911. [329] (Table 16) Similar to the Nihon Railway, the stock was more likely to be distributed to the existing shareholders in spite of the increase in the number of shareholders.

In contrast to its reliance on stock, the Tokyo Electric Light Company did not use bonds at all before World War I. The company was able to raise funds through stock issue only. In fact, the dividend of the common stock was high enough to attract investors. It was from 7 per cent to 12 per cent annually except the years of capital reduction between 1891 and 1893 . Without using domestic bonds, interestingly, the company 
attempted to issue foreign bonds in 1907. In order to finance the construction of hydroelectric power station, it planned to market Sterling bonds of $£ 500,000$ by making a trust contract with the Anglo-American Debenture Corporation Limited. However, this plan was cancelled. In the end, foreign financiers were suspicious of the profitability of the business due to the relatively high cost of electricity compared with gas and the destructive competition among many electric companies in Japan.[330] The company instead increased capital stock by $¥ 10,850,000$.[331]

\begin{tabular}{|c|c|c|c|}
\hline & $\begin{array}{l}\text { The Number of } \\
\text { Shares Outstanding }\end{array}$ & $\begin{array}{l}\text { The Number of } \\
\text { Shareholders }\end{array}$ & $\begin{array}{l}\text { The Average Number } \\
\text { of Shares per Shareholder }\end{array}$ \\
\hline 1882 & 4,000 & 64 & 62.5 \\
\hline 1886 & 10,000 & 56 & 178.6 \\
\hline 1887 & 10,000 & 72 & 138.9 \\
\hline 1888 & 20,000 & 108 & 185.2 \\
\hline 1903 & 70,000 & 397 & 176.3 \\
\hline 1904 & 70,000 & 469 & 149.3 \\
\hline 1907 & 480,000 & 2,999 & 160.1 \\
\hline 1911 & $1,000,000$ & 3,105 & 322.1 \\
\hline 1918 & $1,000,000$ & 4,610 & 216.9 \\
\hline 1924 & $5,160,000$ & 22,542 & 228.9 \\
\hline & & \multicolumn{2}{|c}{ Source: Nippon Teikoku Nenkan }
\end{tabular}

Table 16: Shareholding of the Tokyo Electric Light Company

Although the major financial source of the Tokyo Electric Light was common stock, bank loans played a supplementary role. Especially, in 1905 and 1906, loans accounts for more than 20 per cent of gross assets. (Table 15) The funds raised through the years were mostly used for the construction of the Katsuragawa hydro-electric station. The president, Sakutaro Satake, asked the Mitsui Bank to make loans of $¥ 1$ million in August 1904. Seihin Ikeda, an executive director of Mitsui Bank, was willing to provide the fund. He even suggest that he would make another loans if the company used all of 
the $¥ 1$ million as far as it would repay the first loan through the collection of the installments from shareholders and through the increase in capitalization. By these methods, he believed, the company could easily raise funds due to its high stock price and high dividends. [332]

Banks also contributed corporate finance of the Tokyo Electric Light indirectly through collateral stock loans. In 1907, the President, Satake, borrowed $¥ 180,000$ from the Mitsui Bank on the security of the stock of Tokyo Electric Light. Likewise, the Wakao Bank, the major shareholder of the company, borrowed $¥ 1$ million yen in the same way. These loans were used to pay for the installments of the stock. [333]

However, the role of banks before World War I should not be exaggerated. Bank loans were only temporary financial solutions for the Tokyo Electric Light Company. Except the years of the hydro-electric power construction and right before World War I, the role of loans in corporate finance was not substantial. Second, collateral stock loans were regarded as commercial finance rather than industrial finance. It was an indirect financial source for the industry. Third, banks were not major shareholders of the company. The Mitsui Bank, which had the closest financial relationship with the company, was not eager to own the stock. The business men in the Mitsui group, such as Risuke Minomura and Takashi Masuda, were listed as the promoters when the company was established, but their ownership was only 6 per cent of total stock at the time. In 1916, the bank even did not own the stock at all. [334] Finally, since the company did not use bonds, banks' role as trustees or underwriters was not seen. [335] 


\subsubsection{Corporate Finance from World War I to 1930}

Like other electric utility companies, corporate financial practice of the Tokyo Electric Light Company was changed during and after World War I. The common stock increased from $¥ 39.6$ million in 1914 to $¥ 404.1$ million in 1930 . This increase in capitalization was mostly a result of mergers and acquisitions. The new issue of common stock was a one time event; in 1919 , the company issued stock of $¥ 50$ million in order to expand facilities along with the rapid increase in the demand for electricity. [336] Despite the rapid surge of common stock, however, the contribution of common stock in corporate finance rather declined. The equity ratio decreased from 72.8 per cent in 1914 to 50.3 per cent in 1930 . (Table 17)

(in Yen)

\begin{tabular}{|c|c|c|r|r|r|}
\hline & $\begin{array}{c}\text { A } \\
\text { Gross } \\
\text { Assets }\end{array}$ & $\begin{array}{c}\text { B } \\
\text { Stock }\end{array}$ & B/A & \multicolumn{1}{c|}{$\begin{array}{c}\text { C } \\
\text { Bonds }\end{array}$} & C/A \\
\hline 1915 & $56,539,656$ & $44,787,145$ & $79.2 \%$ & $5,000,000$ & $8.8 \%$ \\
\hline 1916 & $57,838,428$ & $45,163,880$ & $78.1 \%$ & $5,000,000$ & $8.6 \%$ \\
\hline 1917 & $59,317,386$ & $47,508,245$ & $80.1 \%$ & $4,500,000$ & $7.6 \%$ \\
\hline 1918 & $62,041,128$ & $50,000,000$ & $80.6 \%$ & $3,500,000$ & $5.6 \%$ \\
\hline 1919 & $75,739,405$ & $62,500,000$ & $82.5 \%$ & $2,500,000$ & $3.3 \%$ \\
\hline 1920 & $82,475,837$ & $68,500,000$ & $83.1 \%$ & $1,500,000$ & $1.8 \%$ \\
\hline 1921 & $145,017,619$ & $113,973,718$ & $78.6 \%$ & $3,500,000$ & $2.4 \%$ \\
\hline 1922 & $202,043,285$ & $165,044,705$ & $81.7 \%$ & $3,500,000$ & $1.7 \%$ \\
\hline 1923 & $292,867,897$ & $193,770,000$ & $66.2 \%$ & $32,792,300$ & $11.2 \%$ \\
\hline 1924 & $339,789,767$ & $228,605,288$ & $67.3 \%$ & $45,689,000$ & $13.4 \%$ \\
\hline 1925 & $487,926,801$ & $266,962,040$ & $54.7 \%$ & $124,790,800$ & $25.6 \%$ \\
\hline 1926 & $632,846,650$ & $345,091,270$ & $54.5 \%$ & $161,040,800$ & $25.4 \%$ \\
\hline 1927 & $648,874,896$ & $345,698,773$ & $53.3 \%$ & $163,590,800$ & $25.2 \%$ \\
\hline 1928 & $846,404,553$ & $407,149,000$ & $48.1 \%$ & $364,603,500$ & $43.1 \%$ \\
\hline 1929 & $843,293,608$ & $407,149,000$ & $48.3 \%$ & $359,862,502$ & $42.7 \%$ \\
\hline 1930 & $808,719,893$ & $407,149,000$ & $50.3 \%$ & $355,032,823$ & $43.9 \%$ \\
\hline
\end{tabular}

Source: Nitta, Appendix 1

Table 17: Stock and Bonds of the Tokyo Electric Light Company after 1914 
Instead of common stock, the company began to use bonds. The amount of bond issues shapely increased from $¥ 5$ million in 1915 to $¥ 3.6$ billion in 1930 . The ratio of bonds to gross assets was 8.8 per cent in 1915 and 43.9 per cent in 1930. (Table 17) The use of bonds instead of stock was advantageous to the company. Since stock prices sank after the peak of 1910 and reached the bottom in 1914, the company faced the difficulty in selling the stock at face value. [337] Also, costs for bond issues were much cheaper than that of stock issues because the dividends of the stock were higher than interest rates. While interest rates of the company's bond were between 6 and 8 per cent, the dividends of the stock were between 8 and 12 per cent. [338]

In particular, the Tokyo Electric Light relied on foreign bonds as well as domestic bonds. In the 1920s, the company succeeded in three foreign bond issues. In 1923, it issued 6 per cent, $£ 3$ million 25 years Sterling bonds. This issue was the first foreign bond issue made in the electric light industry. The underwriter was the Whitehall Trust Ltd. in London. In 1925, the company also issued both Sterling and Dollar bonds; it required a huge amount of capital to deal with the loss caused by the Kanto Great Earthquake of 1923. These were $£ 600,00023$ years 6 per cent Sterling bonds underwritten by the Whitehall Trust Ltd, and \$2,400,000 3 years 6 per cent Dollar bonds underwritten by the Guaranty Co. of New York. In 1928, the company again issued both Sterling and Dollar bonds. The dollar issue was the $\$ 70$ million 25 years 6 per cent collateral bonds. The underwriter, the Guaranty Co. of New York, required the company of the annual redemption of 1.6 per cent of total issue by using the sinking funds. The trustee was the Mitsui Bank. The Sterling issue was the $£ 4.5$ million 6 per cent 25 years collateral bonds. The underwriters were Lazard Brothers \& Co. and Whitehall Trust \& 
Co. Once again, the trustee was the Mitsui Bank. [339] These issues were used to redeem the short-term dollar bonds of 1923, to reimburse the huge amount of loans made by the Mitsui Bank, and also to raise funds for construction.

Similar to other electric utility companies, the advantage of using foreign bonds was the long maturity period and exchange gains. The maturity periods of foreign debenture bonds were not so different from domestic bonds. However, foreign bonds with security had much longer maturity periods than domestic bonds. While the maturities of the foreign bonds were 25 years, that of domestic bonds were at most 10 years. Also, exchange gains may be one of the important incentives for the company to issue foreign bonds. On the other hand, the difference of interest rates between foreign and domestic bonds did not always create profits. Although the interest rate of foreign bonds was 6 per cent, lower than that of domestic bonds by 1 to 2 per cent, the lower issue price of foreign bonds paid off the profits from the difference of interest rates. The average issue price of domestic bonds was $¥ 97.75$ and that of foreign bonds was $¥ 91$. (Table 14)

Although foreign bond issues were important financial sources for the Tokyo Electric Company in the 1920s, it was not easy to obtain funds through foreign markets. According to Kikkawa, in 1923 when the company issued Sterling bonds, it was allowed to issue bonds only up to a half of its paid-in capital. This restriction prolonged the company's reliance on domestic bank loans. Also, in the bond issue of 1928, the U.S. and British investment bankers accepted underwriting only under the condition that the merger of the Tokyo Electric Light and Tokyo Electric Power Companies should be achieved and that the Sterling bond issue of 1923 should be redeemed. [340] 
As the Tokyo Electric Light used bonds more and more, the role of banks was changed. Banks actively participated in underwriting business for domestic bonds. In particular, the Mitsui Bank dealt with almost all domestic bond issues of the company by itself or through syndicates. In fact, 44 per cent of the underwriting business of the bank was turned to electric utility industry, of which 33 per cent was for the Tokyo Electric Light. [341] Also, as the company relied on foreign bonds, the Mitsui Bank played a role as a trustee for the issue of collateral bonds. [342] As Yasuzaemon Matsunaga, the businessman who contributed so much to the development of the electric utility industry, argues, the credit of the Mitsui was a key to foreign bond issues. In the early 1920s, Japanese banks as well as the electric utility industry were not prepared to issue foreign bonds. Also the business license granted by the government was effective only fifteen to twenty years, while the maturity period of foreign bonds was thirty years. Under these financial and corporate immaturities, the fame and credit of the Mitsui was essential.[343]

Bank loans were also used when the company was not able to meet the financial demand through bond issues. As stated above, in 1923 when the Sterling bond issue was restricted to a half amount of paid-in capital, the company needed to rely on bank loans. Bank loans continued to increase from 1924 to 1927 . In 1928, the company repaid loans through foreign bond issues, but again had to borrow money from banks in 1929 and 1930. Although it issued foreign bonds at that time, these were refunding bonds, not being used to repay the loans. The major bank to make loans to the company was again the Mitsui Bank. Although the bank did not make any loans to the company from 1915 to 1922, it continued to lend money from 1923 after the Kanto Great Earthquake. 
Although the Mitsui Bank was closely associated with the Tokyo Electric Light Company, it was not regarded as a main bank. The bank was hesitant to own stock of any electric utility companies. According to Kikkawa, it only owned $¥ 200,000$ of the stock of the Tokyo Electric Light in 1931. [344] Also, the bank's support for bond issues as an underwriter and a trustee was in part explained by its intention to collect debt from the company, not necessarily to maintain a long-term relationship with the company. [345] Bank's credit toward the company was diminished in the 1920s. Seihin Ikeda, the director of the Mitsui Bank who had been supportive to the company in 1905, stated that the company was no longer able to increase capitalization and to collect funds to repay debt after the Great Kanto Earthquake of 1923. [346] To protect its credit toward the company, the bank helped issue bonds and even interfered with the management of the company through its trusteeship. In 1930, according to the contract between the bank and the company, the company should not pay dividends of more than 5 per cent and that total dividends should not be more than 75 per cent of net profit during the certain time period. In addition, the company was required either to use net profits for the cost for the construction of subsidiaries or to make loans to them. [347]

Meanwhile, reserves were not important financial sources for the Tokyo Electric Light. The company accumulated reserves from $¥ 595$ in 1887 through $¥ 2.6$ million in 1914 to $¥ 26.6$ million in 1930 , but the ratio of reserves to gross assets remained small. Though reserves increased by ten times from 1914 to 1930, gross assets boosted by as mush as fourteen times during the same years. As a result, the ratio of reserves to gross assets was as low as 2 to 7 per cent except the early years. (Table 18) 
(in Yen)

\begin{tabular}{|r|r|r|r|}
\hline Year & $\begin{array}{c}\text { A } \\
\text { Gross Assets }\end{array}$ & $\begin{array}{c}\text { B } \\
\text { Reserves }\end{array}$ & B/A \\
\hline 1915 & $56,539,656$ & $2,737,224$ & $4.8 \%$ \\
\hline 1916 & $57,838,428$ & $3,260,436$ & $5.6 \%$ \\
\hline 1917 & $59,317,386$ & $3,564,200$ & $6.0 \%$ \\
\hline 1918 & $62,041,128$ & $4,007,501$ & $6.5 \%$ \\
\hline 1919 & $75,739,405$ & $4,648,615$ & $6.1 \%$ \\
\hline 1920 & $82,475,837$ & $5,468,587$ & $6.6 \%$ \\
\hline 1921 & $145,017,619$ & $7,845,463$ & $5.4 \%$ \\
\hline 1922 & $202,043,285$ & $11,519,895$ & $5.7 \%$ \\
\hline 1923 & $292,867,897$ & $14,970,326$ & $5.1 \%$ \\
\hline 1924 & $339,789,767$ & $15,885,117$ & $4.7 \%$ \\
\hline 1925 & $487,926,801$ & $17,318,062$ & $3.5 \%$ \\
\hline 1926 & $632,846,650$ & $18,959,879$ & $3.0 \%$ \\
\hline 1927 & $648,874,896$ & $20,930,021$ & $3.2 \%$ \\
\hline 1928 & $846,404,553$ & $22,777,070$ & $2.7 \%$ \\
\hline 1929 & $843,293,608$ & $24,765,220$ & $2.9 \%$ \\
\hline 1930 & $808,719,893$ & $26,575,810$ & $3.3 \%$ \\
\hline
\end{tabular}

Source: Nitta, Appendix 1

Table 18: Reserves of the Tokyo Electric Light

During the pre-World War I period, Japanese electric utilities relied on equity finance, similar to the railroads. In particular, after nationalization of the major railroads of 1906, idle capital was directed to electric utilities, and the stock came to be widely distributed in the public. Although stock was an important financial source after the war, the use of bonds, especially foreign bonds, increased rapidly in the 1920s. On the other hand, banks played only supplementary role in public utility finance throughout the time. Bank loans were temporary and not substantial. They only made collateral stock loans to investors. In the 1920s, they underwrote bonds issued by electric utility companies, through which they could influence on the management of the electric utility companies. Considering the American public utility companies' reliance on bonds, corporate financial practices of Japanese electric utilities was closer to the American model. 
Meanwhile, Japanese banks' underwriting business during the 1920s was quite similar to the activity of investment bankers in the United States.

When securities of electric utility companies came to be held widely in the public, those of cotton spinning gained popularity for speculation purposes. Unlike electric utilities, the securities of the cotton-spinning industry were not suitable for investment because of the price fluctuation of raw materials, mainly raw cotton, and of the final products, cotton yarn, in the markets. [348]

\subsection{Cotton Spinning Finance}

\subsubsection{Cotton-Spinning Finance before World War I}

Until the 1870s, the cotton-spinning was a home-handcraft industry in Japan. To facilitate modernization and to increase productivity under the industrial development policy [shokusan kogyo seisaku], the government attempted to introduce machinery production to the industry. It established government factories as models, sold the spinning machines imported from Britain, and made loans to newly established private spinning firms. However, in the early 1880 s, the cotton-spinning industry in Japan was still small, compared with Britain. While the British average firms had 12,600 spindles in 1866, those of Japanese firms had 2000 spindles only. [349] Since capital required in such a small firm was not huge, the founder and family members could finance the business without relying on external sources. [350]

It was during the 1880 s that large-scale spinning firm appeared without government supports. The Osaka Spinning Company was the first to set up as many as 15,000 spindles. [351] In three years, the number of the firms with 10,000 spindles or

more increased to ten. The spindles of these companies accounted for 74 per cent of all 
the spindles in the industry. [352] As the size of the firms grew, long-term capital was a critical issue in the industry.

The increasing demand for long-term funds in the industry was financed mainly by stock, but the equity ratio in the cotton-spinning industry was much lower than that of railroad and electric utility companies; it account for 50 to 60 per cent. (Table 19) This is explained by the difference of the financial structures between industries. Unlike the other two industries, cotton-spinning firms required huge amounts of working capital to purchase raw materials.

(in Yen)

\begin{tabular}{|c|r|r|r|r|}
\hline & \multicolumn{1}{|c|}{1890} & \multicolumn{1}{|c|}{1893} & \multicolumn{1}{c|}{1894} & \multicolumn{1}{c|}{1898} \\
\hline $\begin{array}{c}\text { Number of } \\
\text { Companies }\end{array}$ & 10 & 24 & 26 & 62 \\
\hline $\begin{array}{c}\text { Gross } \\
\text { Assets }\end{array}$ & $7,505,000$ & $16,555,000$ & $21,654,000$ & $53,114,000$ \\
\hline $\begin{array}{c}\text { Paid-in } \\
\text { Capital }\end{array}$ & $4,761,000$ & $9,137,000$ & $11,212,000$ & $29,271,000$ \\
\hline $\begin{array}{c}\text { Fixed } \\
\text { Assets }\end{array}$ & $4,578,000$ & $10,289,000$ & $13,427,000$ & $37,132,000$ \\
\hline $\begin{array}{c}\text { Fixed/Gross } \\
\text { Assets }\end{array}$ & $61.0 \%$ & $62.2 \%$ & $62.0 \%$ & $69.9 \%$ \\
\hline Equity Ratio & $63.4 \%$ & $55.2 \%$ & $51.8 \%$ & $55.1 \%$ \\
\hline
\end{tabular}

Source: Takamura, vol. 2 p17

Table 19: Fixed assets and Equity of the Cotton Spinning Industry

Stock of cotton-spinning companies was not widely distributed before 1906. When companies were promoted, the stock was sold to rich local merchants, landlords, and politicians without using markets, similar to railroads and electric utility companies.[353] When companies needed to increase capitalization, they allocated most of the stock to the existing shareholders through the efforts of promoters; it was not easy to sell stock due to risk of the business. Therefore, financial power and social status of the promoters played a very important role for the sale of stock. In other words, promoters' 
wealth determined the amount of stock they would subscribe by themselves, and their social status affected the reputation of the stock. [354]

After nationalization of railroads, the stock of spinning companies was widely distributed to the public. Similar to electric utility, part of idle funds brought about by nationalization of railroads was directed to speculation of cotton-spinning stock. According to Kazuo Yamaguchi, in 1914, fifteen industrial firms were listed in the Tokyo and Osaka Stock Exchanges, of which twelve were cotton-spinning companies. [355]

Bonds were much less important than stock in cotton-spinning finance before 1907. The companies considered the use of bonds only when they were unable to increase capitalization through stock issues. Since the Bank of Japan did not discount these bonds, they were rarely listed on markets. Facing the difficulty in selling bonds, the companies mostly allocated them to existing shareholders. [356]

After the Russo-Japanese War, however, huge amounts of cotton spinning bonds came to be issued, which were used for the expansion of facilities. The newly issued bonds were often distributed to new investors through public offering by banks. The reasons of this bond boom were explained by three factors. First, the Collateral Trust Bond Law of 1905 alleviated risk of bonds. Second, as the scale of the business increased, firms required more funds than before. Finally, risk of bonds was reduced by establishing syndicates consisting of bankers and stockbrokers. [357]

These bonds were domestic bonds; no foreign bonds were issued in cottonspinning industry before and after World War I. Foreign investors were not willing to take risk of industrial securities. In fact, the business was not stable due to fluctuating 
market prices of raw cotton and cotton yarn, and it did not have properties suitable for collateral unlike the railroad and electric utilities.

As the business came to be profitable, spinning companies accumulated reserves, which were used to finance part of fixed assets from time to time. Table 20 shows that while the ratio of stock to total long-term capital (Column A) decreased from 88.2 per cent in 1902 to 57 per cent in 1914, that of reserves increased from 11.8 per cent in 1902 to 24.8 per cent in 1914 . To a lesser extent, bonds also increased; they accounted for 18 per cent of long-term capital in the industry in 1914. In other words, the decline of the role of stock was compensated for mainly by the increase in reserves and then the increase in bonds. (Table 20) This trend was further accelerated after 1914.

One of the remarkable differences between railroads and public utilities, on the one hand, and the spinning companies, on the other, was that the latter needed huge amounts of working capital in order to purchase raw cotton. At first firms used raw cotton grown in Japan, which they could buy it on credit from domestic producers. However, their financial method was transformed as they obtained raw cotton from foreign countries. After the late 1880 s, they came to use raw cotton imported from China, most of which was dealt in by Chinese merchants, not Japanese traders. Since Chinese merchants required payment at the time of possession, the spinning companies, without sufficient funds to afford the purchase, needed bank loans to secure ready cash. [358]

After the depression of 1897 , instead of bank loans, cotton-spinning companies obtained credit from Japanese trading companies under special contracts called Tokuyaku. Under the contract, the firms were allowed to pay with promissory notes for raw cotton to the trading companies they contracted. Instead, they had to buy raw cotton exclusively 
from the trading companies, which dealt with raw cotton imports from the United States.[359] For example, the Mitsui Trading Company's New York office handled raw cotton imported from the United States. The company was responsible for more than 30 per cent of the U. S. raw cotton imported into Japan.[360] In fact, it was difficult for them to receive loans from banks at that time because the Bank of Japan decreased liquidity by reducing loans and bills discounted. The adoption of special contracts was advantageous to both parties. While the trading companies secured the markets of raw cotton, the companies were relieved from financial burdens. [361]

(per cent)

\begin{tabular}{|c|r|r|r|}
\hline & \multicolumn{1}{|c|}{ A } & \multicolumn{1}{c|}{ B } & \multicolumn{1}{c|}{ C } \\
\hline 1902 & 88.2 & 0 & 11.8 \\
\hline 1904 & 84.1 & 0 & 15.9 \\
\hline 1906 & 64.4 & 7.0 & 28.6 \\
\hline 1908 & 62.0 & 12.5 & 25.5 \\
\hline 1910 & 57.5 & 19.1 & 23.4 \\
\hline 1912 & 58.8 & 17.3 & 23.9 \\
\hline 1914 & 57.0 & 18.2 & 24.8 \\
\hline
\end{tabular}

Source: Takamura, Nihon Boseki Shi, vol.2, p120
A: paid-in capital/fixed capital; B: Bonds and loans/ fixed capital;
C: reserves/fixed capital.
Table 20: The Ratios of Financial Sources to Gross Assets in the Cotton Spinning Industry.

After the Russo-Japanese War, however, the issue of promissory notes diminished. As retained earnings accumulated, funds available for working capital increased. Now, promissory notes were more likely to be used as an effective financial tool rather than a necessary means. For example, in 1914, the issue of notes increased temporarily because the discount rate was lower than interest rate. [362] 


\subsubsection{Cotton Spinning Finance From World War I to 1930}

During World War I, an oligopolistic industrial structure appeared in the industry. The three biggest companies were the Toyo Spinning Company, Dai-Nihon Spinning Company, and Kanebuchi Spinning Company. The former two were established through mergers in 1914. The Toyo Spinning was formed through the merger of the Mie Spinning Company and the Osaka Spinning Company, and Dai-Nihon Spinning was through the merger of the Amagasaki Spinning Company and the Settsu Spinning Company. Meanwhile, the Kanebuchi Spinning had expanded itself through acquisitions since the 1890s. [363] In 1918, the three companies produced 51.1 per cent of cotton yarn production. [364]

Making high profits, these big cotton-spinning companies were directed to selffinance. In the end of 1918, according to Yamaguchi, their reserves accounted for 56.9 per cent of all the reserves in the industry. Using three quarters of their reserves, they could have paid off all borrowed capital. [365] Thus, along with the emergence of oligopoly, the major cotton-spinning firms achieved financial independence.

Again, the roles of banks were not direct. For long-term finance, they made stock collateral loans to individuals. [366] After 1907, banks also began to underwrite cottonspinning bonds. On the other hand, short-term loans made by banks to cotton spinning firms were ceased to exist. As explained above, the role of banks in short-term finance were replaced by the trading companies that could provide them with credit, and later major spinning firms were able to rely on self-finance.

Thus, the cotton spinning firms were usually free from the pressure of shareholders due to wide distribution of stock and maintained loose relation with bankers. 
However, these financial practices were not always applicable. Before World War I, corporate financial practices of the Kanebuchi Spinning were different from other major cotton spinning firms.

\subsubsection{The Kanebuchi Spinning Company}

\subsubsection{Corporate Finance before World War I}

In 1886, the Tokyo Cotton Trading Ltd, the predecessor of the Kanebuchi Spinning Company, was established with the capitalization of $¥ 100,000$. Its promoters were mainly merchants including Tokuemon Mitsukoshi, the president of Mitsukoshi Kimono Shop, and Wakichiro Omura, the president of the Sirakiya Department Store. Although the business began as a pure trading company, it came to deal with cotton spinning as well to market the raw cotton they bought. Facing the difficulty in trade due to the economic recession in the late 1880 s, the company finally specialized in spinning business alone in August 1889, changing the corporate name to Kanebuchi Spinning Company Ltd.

From the beginning, the company was huge and grew sharply in size; it held 30,000 spindles, twice the size of the first large-scale spinning company, the Osaka Cotton Spinning Company. As Figure 15 shows, its gross assets also rapidly increased. It was only $¥ 28,781$ when the Tokyo Cotton Trading was established. However, it came to be more than $¥ 10$ million in the early twentieth century, and before World War I, it reached $¥ 40$ million.

Although the proportion of fixed assets to current assets of the Kanebuchi Spinning was much larger than other companies in the industry due to its gigantic size, it was still smaller than that of railroads and electric utilities. According to Yamaguchi, the 
company's fixed assets including buildings, equipments and land accounted for 60 per cent of gross assets from 1889 to 1892,75 per cent from 1898 to 1902 , and 58 per cent from 1905 to 1908. The high per centage of fixed assets in the second time period was attributable to mergers. The company merged seven companies and added $¥ 3,430,000$ to its fixed assets at that time. [367]

(in Yen)

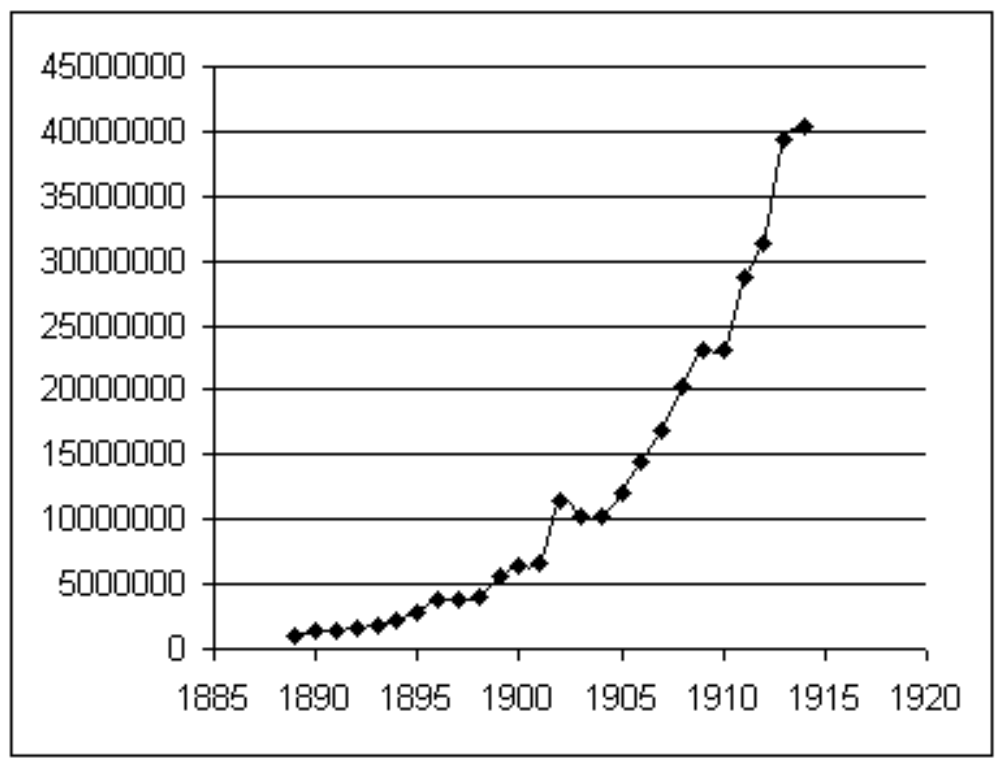

(Source: Yamaguchi, Appendix 2)

Figure 15: The Increase in Gross Assets of the Kanebuchi Spinning.

Common stock was the major method to meet the increasing financial needs, but its role should not be exaggerated. [368] As Table 21 shows, the reliance on stock gradually decreased. After 1905, stock financed less than half gross assets.

The stock of the company was not widely held by the public in its early years. When the Tokyo Cotton Trading was formed, the stock was sold to the merchants in the same industry. [369] In 1888, when the company needed additional funds to purchase 
Ring spinning machines, the House of Mitsui undertook the unpaid parts of stock. [370] During the recession of 1889 , the Mitsui Bank also bought the stock of shareholders that were insisting on the dissolution of the company.[371] As a result, in 1899, Mitsui held 24,282 shares, most of which was owned by Takayasu Mitsui, the president of the Mitsui Bank. The Mitsui's stock ownership accounted for 48 per cent of the total numbers of the shares. In 1902, Takayasu Mitsui still held 38,100 shares equivalent to 32.8 per cent of the total stock. [372] The concentration of the stock holding was also seen in the number of the stock transferred through the market. In the Tokyo Stock Exchange, the number of the shares transferred was not significant especially before the nationalization of railroads in 1905, and it is not until 1914 that the transfer of the stock increased in real earnest. (Figure 16)

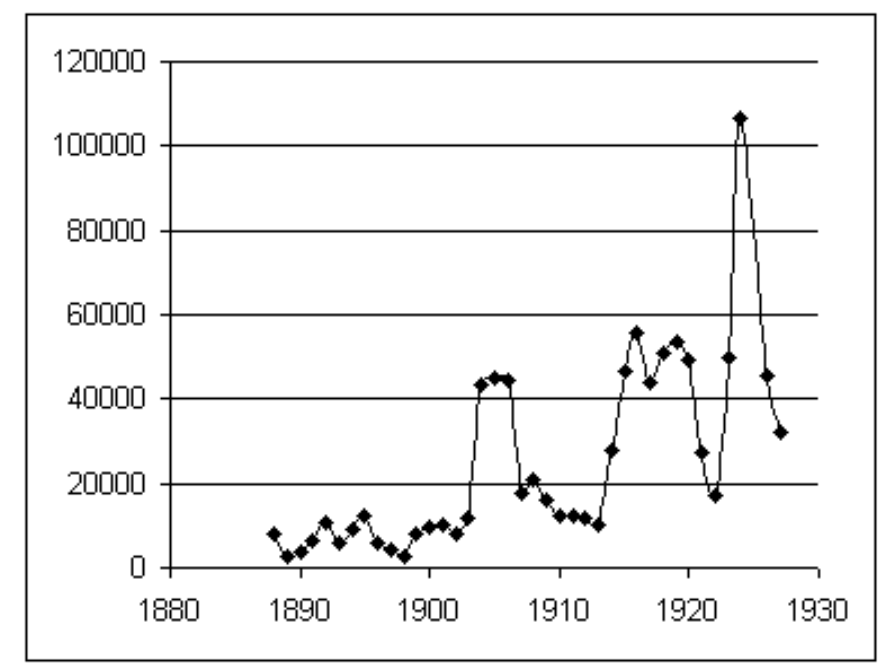

Source: Tokyo Kabushiki Torihikijo, p179-189, Table 60

Figure 16: The Number of Share of the Kanebuchi Spinning Transferred in the Tokyo Stock Exchange. 
(in Yen)

\begin{tabular}{|c|c|c|c|c|c|c|c|}
\hline & $\begin{array}{c}\text { A } \\
\text { Gross Assets }\end{array}$ & $\begin{array}{c}\text { B } \\
\text { Sock }\end{array}$ & $\mathrm{B} / \mathrm{A}$ & $\begin{array}{c}\text { C } \\
\text { Reserves }\end{array}$ & $\mathrm{C} / \mathrm{A}$ & $\begin{array}{c}\mathrm{D} \\
\text { Bonds }\end{array}$ & $\mathrm{D} / \mathrm{A}$ \\
\hline 1889 & $1,078,800$ & 893,100 & $82.8 \%$ & - & & & \\
\hline 1890 & $1,455,300$ & 985,700 & $67.7 \%$ & 2,500 & $0.2 \%$ & & \\
\hline 1891 & $1,423,200$ & 986,800 & $69.3 \%$ & 2,500 & $0.2 \%$ & & \\
\hline 1892 & $1,551,500$ & $1,000,000$ & $64.5 \%$ & 23,300 & $1.5 \%$ & & \\
\hline 1893 & $1,798,100$ & $1,249,700$ & $69.5 \%$ & - & $0.0 \%$ & & \\
\hline 1894 & $2,237,400$ & $1,785,400$ & $79.8 \%$ & 25,000 & $1.1 \%$ & & \\
\hline 1895 & $2,839,300$ & $2,393,400$ & $84.3 \%$ & 35,000 & $1.2 \%$ & & \\
\hline 1896 & $3,821,100$ & $2,500,000$ & $65.4 \%$ & 60,000 & $1.6 \%$ & & \\
\hline 1897 & $3,776,900$ & $2,500,000$ & $66.2 \%$ & 85,000 & $2.3 \%$ & & \\
\hline 1898 & $4,023,600$ & $2,500,000$ & $62.1 \%$ & 103,700 & $2.6 \%$ & & \\
\hline 1899 & $5,710,200$ & $3,400,000$ & $59.5 \%$ & 119,000 & $2.1 \%$ & & \\
\hline 1900 & $6,499,700$ & $4,000,000$ & $61.5 \%$ & 143,800 & $2.2 \%$ & & \\
\hline 1901 & $6,688,400$ & $4,000,000$ & $59.8 \%$ & 143,800 & $2.1 \%$ & & \\
\hline 1902 & $11,456,097$ & $5,803,400$ & $50.7 \%$ & 491,800 & $4.3 \%$ & & \\
\hline 1903 & $10,203,419$ & $5,803,400$ & $56.9 \%$ & 641,891 & $6.3 \%$ & $1,000,000$ & $9.8 \%$ \\
\hline 1904 & $10,289,300$ & $5,803,400$ & $56.4 \%$ & 941,800 & $9.2 \%$ & $1,000,000$ & $9.7 \%$ \\
\hline 1905 & $12,133,400$ & $5,803,400$ & $47.8 \%$ & $1,897,100$ & $15.6 \%$ & 935,000 & $7.7 \%$ \\
\hline 1906 & $14,506,600$ & $5,803,400$ & $40.0 \%$ & $3,861,400$ & $26.6 \%$ & 765,000 & $5.3 \%$ \\
\hline 1907 & $16,946,400$ & $7,854,200$ & $46.3 \%$ & $4,862,700$ & $28.7 \%$ & 595,000 & $3.5 \%$ \\
\hline 1908 & $20,377,400$ & $7,854,200$ & $38.5 \%$ & $5,167,200$ & $25.4 \%$ & 425,000 & $2.1 \%$ \\
\hline 1909 & $23,039,900$ & $9,083,400$ & $39.4 \%$ & $5,362,700$ & $23.3 \%$ & 255,000 & $1.1 \%$ \\
\hline 1910 & $23,148,600$ & $9,905,100$ & $42.8 \%$ & $5,562,700$ & $24.0 \%$ & $3,085,000$ & $13.3 \%$ \\
\hline 1911 & $28,783,900$ & $11,825,900$ & $41.1 \%$ & $5,737,700$ & $19.9 \%$ & $6,000,000$ * & $20.8 \%$ \\
\hline 1912 & $31,431,600$ & $12,646,200$ & $40.2 \%$ & $6,038,100$ & $19.2 \%$ & $6,000,000$ & $19.1 \%$ \\
\hline 1913 & $39,357,400$ & $14,966,600$ & $38.0 \%$ & $6,338,100$ & $16.1 \%$ & $5,750,000$ & $14.6 \%$ \\
\hline 1914 & $40,284,000$ & $14,966,600$ & $37.2 \%$ & $6,638,100$ & $16.5 \%$ & $5,250,000$ & $13.0 \%$ \\
\hline
\end{tabular}

Source: Yamaguchi, Appendix 2

* Through the acquisition of the Kenshi Spinning, the company undertook the bonds of $¥ 3$ million yen

Table 21: Long-Term Finance of the Kanebuchi Spinning

Bonds were less important financial sources than stock before World War I, but their use gradually increased, especially when banks collected debts. The company issued $¥ 1$ million 8 years 7 per cent debenture bonds in 1903. The purpose of this issue seemed to repay the loans made by the Mitsui Bank. In fact, this issue was underwritten by the Mitsui Bank itself, and the balance of bank loans that was made by Mitsui Bank diminished in this year. [373] The second bond issue was in 1910. It was $¥ 3,000,000,9$ 
years 6.5 per cent debenture bonds underwritten by the Yasuda Bank. Using the bonds, the company returned the loans of $¥ 2.5$ million from Mitsui, Mitsubishi, and Daiichi Banks and financed part of working capital. [374] Since these bonds were not listed in the Tokyo Stock exchange, the company relied on the underwriters to allocate them.

The Kanebuchi Spinning Company was an exception that created close ties with a bank in its early years. The Mitsui Bank supported its corporate finance not only through collateral stock loans. The Bank was the largest shareholder of the company, as mentioned above. It also made loans to the company. For example during the recession of 1890 , the company borrowed $¥ 600,000$ to $¥ 700,000$ from the bank. [375] In 1899 , when acquiring the Kawasu Spinning, the Shibajima Spinning, and Awaji Spinning, it also received about $¥ 1$ million from the bank.[376] Through these financial supports, the leading businessmen in the Mitsui bank, such as Hikojiro Nakamigawa and Eiji Asabuki, participated in the management of the company. [377]

However, the Mitsui bank's involvement in the company weakened in the early twentieth century. The bank began to collect debt from the company in 1900. According to Yamaguchi, tight money caused by the imbalance of export and import, the criticism toward the Bank made by a publishing company, the Niroku Shin'po, and the death of Hikojiro Nakamigawa, who facilitated industrial finance, all led the Bank to conservative management and made the Bank apart from the company. [378] Instead, the company came to rely on the short-term loans from the Yokohama Specie Bank and the Mitsubishi Bank. It also directly borrowed from the Bank of Japan on the security of raw cotton.[379] This financial trouble was finally solved through the long-term loans of $¥ 500,000$ from the Hypothec Bank of Japan and a bond issue of $¥ 1,000,000$. [380] In 
1905 , when the Russo-Japanese war took place, the company again borrowed $¥ 600,000$ from the Mitsubishi Bank, since the Mitsui Bank was reluctant to make loans to other companies than the Mitsui Trading Company. [381]

The Mitsui Bank also sold the stock of the company after the death of Nakamigawa, following the scale-down policy directed by Kaoru Inoue, the advisor of the Mitsui group. At that time, approximately 40,000 shares were sold to a Chinese merchant, Gokindo, which were then sold to a speculator, Kyugoro Suzuki. In the end, after the depression of 1907, price of the stock was plummeted, and all the stock Suzuki had was again transferred to his creditor, the Yasuda Bank. [382]

The role of the Mitsui Bank in Kanebuchi Spinning further diminished as the company accumulated reserves. It used reserves instead of capital stock and loans to reduce the financial costs. In particular, after the Russo- Japanese War, the company could increase reserves due to high profits. The ratio of reserves to gross assets increased from 15.6 per cent in 1905 to 28.7 per cent in 1907. After 1907, the ratio was decreased but still much higher than that of before 1905. (Table 21)

In addition to fixed capital, financing working capital was an important issue for the Kanebuchi Spinning, mainly because the business required purchasing a huge amount of raw cotton. Costs for the purchase of raw cotton accounted for more than a half of gross assets. For working capital, like other spinning firms, the company at first relied on short-term bank loans to obtain cash because it mainly purchased raw cotton imported from China through spot transactions. [383] The Mitsui Bank was a major bank to make loans to the company. [384] 
The role of the Mitsui Bank as a creditor, however, was transformed to a more and more indirect form in the twentieth century. As the Kanebuchi Spinning used raw cotton made in India because of its price reduction, the Mitsui Trading Company played a significant role in financing the purchase of raw cotton. The Kanebuchi Spinning and the Mitsui Trading Companies entered into a special contract in dealings of raw cotton. According to the contract of 1901, the Kanebuchi Spinning should entrust the Mitsui Trading Company with the imports of raw cotton, and it should purchase not less than 70 per cent of the total demand of all factories. Through this contract, the Mitsui Trading Company was successfully secured the market of raw cotton; the Kanebuchi Spinning purchased 60 per cent of total raw cotton imported by the Mitsui Trading Company.[385] In return, the Kanebuchi Spinning was allowed to pay with promissory notes for the purchase of raw cotton.

The role of the Mitsui Bank was to provide the business of the Mitsui Trading Company with financial supports; it not only discounted the notes issued by the Kanebuchi Spinning toward the Mitsui Trading Company, but also prepared foreign exchange for imports done by the Mitsui Trading Company. [386] For example, in 1906, the bank made a contract with the Barclays Bank in London. Under this contract, the Mitsui Bank gave the Japanese national bond equivalent of $¥ 1.5$ million on security and maintained the deposit of $£ 10,000$ without interest. In return, the Barclays Bank promised to provide $£ 50,000$ immediately and another $£ 50,000$ in a week from a notice. During the 1910s, the Mitsui bank also made exchange contracts with foreign banks such as Kleinwort Sons, Frederick Huth \& Co., and Parr's Bank in London, the National Bank of New York, and the Disconto-Gesellshaft in Berlin, Commerz und Disconto Bank in 
Hamburg, and Banque de L'Union Parisienne and Comptoir National d'Escompte in Paris.[387]

The other financial source beyond bank loans and promissory note issues was short-term foreign capital. In 1907, the Kanebuchi Spinning borrowed $¥ 2$ million at interest of 7.5 per cent from a French bank without any pledge of property. The Osaka Mainichi Newspaper stated that this financial practice was based on credit and a simple way of note discounts. In other words, the Kanebuchi Spinning did not offer collateral, but both Mitsui and Mitsubishi Bank guaranteed the payment of interest rate. Also, foreign note issues of $¥ 1$ million in 1913 and $¥ 2.5$ million in 1914 were underwritten by the Midland Bank, under the endorsement of the Yokohama Specie Bank. So that the company could obtain funds at low interest from the international market, Japanese banks indirectly supported its financial needs. The banks guaranteed or underwrote foreign note issues. [388]

Thus, Kanebuchi Spinning had close ties with the Mitsui Bank in the late nineteenth century. The relationship between the company and the bank seemed similar to the one in the main banking system of post-World War II Japan, considering the importance of financial ties and the role of banks in management in both cases. However, the connection was loosened in the early twentieth century as the spinning company came to tie with many other banks in various ways.

\subsubsection{Corporate Finance after World War I}

After World War I, Kanebuchi Spinning, as one of the biggest cotton spinning companies in Japan, continued to grow. Its gross assets were ¥100 million in 1923 and increased to $¥ 130$ million in 1930 . In spite of increasing financial needs, the company 
used fewer and fewer securities and loans. Common stock was still an important financial source, but the equity ratio rapidly diminished. While the equity ratio in the early twentieth century was more than 50 per cent, that of 1923 to 1930 was from 16.1 per cent to 20.1 per cent. Also, there were no loans, and only a small amount of bonds were issued during the time period.

(in Yen)

\begin{tabular}{|r|c|c|c|c|r|r|r|}
\hline Year & $\begin{array}{c}\text { Gross } \\
\text { Assets }\end{array}$ & \multicolumn{2}{|c|}{ Stock } & \multicolumn{2}{c|}{ Reserve } & \multicolumn{2}{c|}{ Bonds } \\
\hline 1923 & $100,222,845$ & $16,486,970$ & $(16.5 \%)$ & $18,438,191$ & $(18.4 \%)$ & $1,250,000$ & $(1.2 \%)$ \\
\hline 1924 & $140,629,954$ & $28,595,737$ & $(20.1 \%)$ & $29,438,191$ & $(20.7 \%)$ & 750,000 & $(0.5 \%)$ \\
\hline 1925 & $117,744,528$ & $28,595,737$ & $(19.2 \%)$ & $30,438,191$ & $(20.4 \%)$ & 250,000 & $(0.2 \%)$ \\
\hline 1926 & $114,920,004$ & $28,595,737$ & $(19.5 \%)$ & $31,438,191$ & $(21.5 \%)$ & - & \\
\hline 1927 & $118,045,370$ & $28,595,737$ & $(19.1 \%)$ & $32,438,191$ & $(21.7 \%)$ & - & \\
\hline 1928 & $126,669,377$ & $28,595,737$ & $(18.1 \%)$ & $33,428,191$ & $(21.1 \%)$ & - & \\
\hline 1929 & $145,989,464$ & $28,595,737$ & $(16.1 \%)$ & $34,438,191$ & $(19.4 \%)$ & $20,000,000$ & $(11.3 \%)$ \\
\hline 1930 & $129,572,060$ & $28,595,737$ & $(17.8 \%)$ & $35,238,191$ & $(21.9 \%)$ & $20,000,000$ & $(12.4 \%)$ \\
\hline
\end{tabular}

Source: Eigyo Hokokusho

Table 22: Financial Sources of the Kanebuchi Spinning from 1923 to 1930

(in Yen)

\begin{tabular}{|c|r|r|r|}
\hline Year & $\begin{array}{c}\text { A } \\
\text { Gross } \\
\text { Assets }\end{array}$ & $\begin{array}{c}\text { B } \\
\text { Retained Earnings } \\
\text { (Reserve+ Surplus) }\end{array}$ & \\
\hline 1923 & $100,222,845$ & $37,228,402$ & $37.1 \%$ \\
\hline 1924 & $140,629,954$ & $45,712,056$ & $32.5 \%$ \\
\hline 1925 & $117,744,528$ & $48,670,424$ & $41.3 \%$ \\
\hline 1926 & $114,920,004$ & $50,036,334$ & $43.5 \%$ \\
\hline 1927 & $118,045,370$ & $50,623,292$ & $42.9 \%$ \\
\hline 1928 & $126,669,377$ & $51,891,338$ & $41.0 \%$ \\
\hline 1929 & $145,989,464$ & $53,107,194$ & $36.4 \%$ \\
\hline 1930 & $129,572,060$ & $54,132,651$ & $41.8 \%$ \\
\hline
\end{tabular}

Source: Eigyo Hokokusho

Table 23: Retained Earnings of the Kanebuchi Spinning 
The reduction of the equity ratio meant that the company moved to self-finance. The trend of the increase in reserves since 1907 had continued. The ratio of reserves to gross assets from 1923 to 1930 was between 18.4 per cent and 21.9 per cent, slightly larger than the equity ratio. (Table 22) The use of reserves was facilitated by its cost effectiveness because the cost of stock finance was quite high in the company; the dividend rate from 1923 to 1930 was between 26 and 35 per cent. If surplus is added to reserves, the ratio to gross assets become between 32.5 and 43.5 per cent. (Table 23) Furthermore, if depreciation, which was not shown in balance sheet, is considered, the trend of self-finance would be shown more explicitly. Thus, The Kanebuchi Spinning at first relied on the Mitsui Bank and Mitsui Trading. However, the relationship between Mitsui and the Kanebuchi Spinning was gradually loosened. Instead, the company came to rely on many other banks and even to issue bonds. Most importantly, as it accumulated profits, its major financial source was retained earnings.

\subsection{Conclusion}

Unlike the post-war main banking system and the Gerschenkron's theory that banks are necessary to the industrialization of latecomers, the three major Japanese industries in early industrialization heavily relied on stock finance. In all three industries, the ownership of common stock was in general widely distributed in the public. On the other hand, the role of bank was indirect. What they did was to make stock collateral loans to facilitate stock sales and support bond issues as underwriters and trustees.

In spite of these similarities among the three industries, each industry has its own corporate financial practices. The railroad industry could issue domestic bonds from the 
early years due to its strong credit and government support. It was the predecessor of modern corporate finance. On the other hand, electric utility companies increased bond issues after 1905. Especially, their reliance on foreign bonds in the 1920s was noteworthy. They created ties with banks, but the main role of banks was to support bond issues. Meanwhile, the cotton spinning industry required consideration of short-term as well as long-term finance. While the industry relied on stock and bonds for long-term capital, it used bank loans and then credit from trading companies for short-term capital. However, as the industry formed the oligopolistic structure, major firms were directed to self-finance.

Furthermore, corporate financial practices were often different from firm to firm within the same industry. While the three companies examined in this chapter maintained some of the industry-specific financial characteristics, their financial practices were not always the same as other companies in the same industry. For example, while the stock in the railroad industry in general came to be widely distributed in the late nineteenth century, that of the Nihon Railway was not. The number of shareholders of the company even decreased from 9,527 in 1883 to 2,682 in 1893. Until 1906, it reached to 4,497, but average number of stock per shareholder increased due to the rapid increase in capitalization. This tendency is attributed to the safety and profitability of the stock ownership under the support of the government. The company also could avoid using bonds. While other major railroad companies needed to rely on bond finance during the recessions, it was able to raise funds through stock due to investors' confidence.

Also, the corporate financial practice of the Tokyo Electric Light Company was different from other major electric utility firms. Although many electric utility companies 
tied with banks in the 1920s, the relationship between the company and the Mitsui Bank, the most aggressive financier in the industry among the banks, was the closest. The bank often intervened in company's finance. However, bank's power was not based on ownership but on its significant financial role, that is that making loans and support bond issues as underwriter or as trustee.

Finally, although cotton-spinning companies grew in general without affiliation with zaibatsu, the Kanebuchi Spinning was an exception. After the reconstruction of the company in the late 1880s, Mitsui involved in corporate finance and management of the company. The company was officially regarded as an affiliated company of the Mitsui group until the early twentieth century. During the time period, unlike other companies, the stock ownership of the company was highly concentrated. 


\section{Chapter 4}

\section{CORPORATE FINANCE OF THE HOLDING COMPANY}

\subsection{Introduction}

In the previous chapters, financial sources in the major industries including securities, loans, and self finance were examined in conjunction with the development of the securities market and the banking system in the United States and Japan. This chapter, from another viewpoint, examines holding companies, which played a role as important financial intermediaries in both nations. In the United States, to attain monopoly and managerial efficiency, the holding company system was widely adopted in railroads and then public utilities. Through the holding company system, a number of companies were consolidated into gigantic entities with smaller amounts of capital than required by mergers and acquisitions. In Japan, on the other hand, holding companies in family-based corporate groups called zaibatsu came to play a role in the national economy. A financier, having been involved in corporate finance of the major three industries - the railroad, electric light, and cotton spinning industries, the zaibatsu was a managerial form to attain loose control over major firms in other industries. According to Michael L. Gerlach, zaibatsu achieved both "strategic centralization" and "operational decentralization." While the head office and key institutions such as a bank and a trading company within a group made "integrated decision," and allocated resources strategically, zaibatsu took advantages of "creating entrepreneurial initiative, organizational flexibility, and close ties to strategic partners associated with satellite information" by using the holding company system. [389] 
This chapter examines the emergence of the holding company, its managerial and financial roles, and its corporate financial practices in the United States and Japan. The holding companies in each nation had different functions from each other due to the difference in the size of the market, the stage of economic development, and the place of family business. Also, the relationship between the holding company on the one hand and the securities markets and banks on the other hand was different from one nation to the other.

\subsection{Holding Companies in the United States}

\subsubsection{The Holding Company and Its Early History}

The holding company was defined as any company, which controls or influences the management of the constituent companies by virtue of "its ownership of securities of the latter." [390] The holding company usually obtains the shares of other companies in exchange for its own stock, or by selling its own stock and using the proceeds to purchase the stock of other companies. In general, there are two types of holding companies: the pure holding company and the parent company. The former does not engage in any operation but holds stocks of other companies; the latter is an operating company that also owns stocks of other companies.

Before 1888, for the most part, holding companies in the United States were created under special authorization from state legislatures. Overall, corporations were not given the legal power to obtain stocks in other companies. The courts of most states denied such corporate power in general and accepted it only when specific legislative permission was granted to a company. No state granted such power in its general laws at first. For example, in 1832, the Baltimore and Ohio Railroad Company were granted the 
power to subscribe to nearly two-thirds of the stock of the Washington Branch Road by the state of Maryland. In 1853, The Pennsylvania Railroad Company received authorization "to subscribe to the capital stock or guarantee the bonds of other companies to the extent of 15 per cent of its own paid-in capital stock.'[391] The Western Union Telegraph obtained power to own stock of other telegraph companies in 1864. In 1880, The American Bell Telephone Company was created by a special Massachusetts charter and authorized to own stock up to 30 per cent of the stock of any telephone company in Massachusetts. [392]

While these companies' right to own stock was limited to certain companies or industries, a few corporations were granted much broader power to hold the stocks of any companies. In particular, the Pennsylvania legislature authorized more than forty corporations with broad power of stockholding between 1868 and 1872. The Pennsylvania Company, which was a pure holding company investing in the Pennsylvania Railroad system, was one of the examples. [393]

Thus, corporate executives were not allowed to form holding companies without authorization from state legislature before the late 1880 s. However, they were able to build a prototype of holding companies, called trusts, without any special grant from the state legislature. According to Edward S. Meade, trusts were organizations that held the stock of several firms in the same industry, and permitted the firms to work out agreements on prices, product and profits among the members. To secure this agreement, the constituent companies deposited their stocks with the trustees and in return received trust certificates. Through this organization, companies attempted to restrict competition. 
The trustee, holding stocks of constituent companies, managed them and secured "a uniform policy upon prices and output."[394]

In fact, however, the role of trusts was more than the restriction of competition. For example, the Standard Oil Trust controlled all aspects in the oil industry through its holdings of the securities in forty-one participating companies; it engaged in "buying, transporting, storing, refining, and marketing petroleum products. "[395] It also made it easy to transfer holdings, to keep all operations in secrecy, and to achieve more efficient administration. [396]

The transformation from trusts to holding companies was triggered by the revision of general corporation laws of New Jersey in 1889, the passage of the Sherman Antitrust Act of 1890, and the Ohio Court ruling in 1892. The new corporation laws in New Jersey approved the "right to purchase the stock of any company or companies owning, mining, manufacturing, or producing materials or other property necessary for their business and to issue stock in payment therefore."[397] It was not difficult to meet the conditions necessary to make use of this law. Promoters were required to pay "a small fee and annual tax," to set up "a principal office in New Jersey," to prepare "the stock-transfer books for inspection," to turn in "annual reports to the Secretary of State," to hold "annual shareholders meeting at the New Jersey office, and to elect at least one directors who is a resident of New Jersey."[398] Following New Jersey, other states such as New York, Connecticut, Pennsylvania, and Delaware also adopted similar provisions before 1890 in order to attract businesses. However, the New Jersey law was more respectable by lawyers and business men" than those in other states. Through enactments in 1893 and 1896, the law became "broader and more specific". The popularity of New 
Jersey laws, for example, led to the unification of all standard oil companies under a holding company, Jersey Standard in 1899.[399]

The use of the holding company was facilitated by the Sherman Antitrust Act of 1890. It declared every combination in the form of a trust illegal. As a result, all trusts were forced to dissolve. However, a majority of the stock in the constituent companies of a trust was often retained by the important businessmen. Seeking a method to maintain their control in the industry, they turned to a new corporate form, the holding company.

Finally, the Ohio Court ruling in 1892 forced firms to move from the use of trusts to the adoption of the holding company. In 1890, the attorney general, David K. Watson filed a case against the Standard Oil Trust by pleading that the trustees who received the stock in the Standard Oil Company of Ohio had controlled the management of the Ohio Company and the company was empowered through association with the trust and achieved monopoly. The company responded, "its shares had been transferred to the Trustees by the stockholders, not by the company, and that Ohio Standard was controlled by the majority holders of stock, albeit they were actually the Trustees of the Standard Oil."'[400] However, the Judge of the Ohio Supreme Court, T.A. Minshall decided that "Ohio Standard was...controlled and managed by the Standard Oil Trust." He continued that its object was "to establish a virtual monopoly of the business" in the oil industry, by which "it might not merely control the production, but the price, at its pleasure". [401] The decision prohibited Ohio Standard from maintaining the Trust Agreement. As a result, the executives of Standard Oil reduced the number of the constituent companies from the ninety-two to twenty and distributed the shares of these twenty companies to owners of certificates in the Trust. Then, they decided to set Standard Oil Company of 
New Jersey, the leading operation unit in the Standard Oil, as a holding company by exchanging its shares for all the investments of the Trust. [402]. After the formation of this holding company in the Standard Oil group, the use of holding companies became the most important form of combination in the early twentieth century. For Standard Oil, the reorganization process was completed in 1899. [403]

In fact, the holding company was quite similar to the trust; in the holding company, trust certificates were replaced by the shares of the holding companies, trustee and trust by "owner and property of holding companies," and a board of trustees by "a board of directors of the holding company."[404] While each constituent company was an independent corporation, the holding company, which owned a controlling interest of each company, obtained power as trusts did. [405]

\subsubsection{The Holding Company in the United States before World War I}

\subsubsection{Managerial Roles of the Holding Company}

After the formation of the holding company in the Standard Oil group, companies came to adopt the holding company for various managerial purposes. One of the most important was to evade competition. In particular, in railroads, to control rate-cutting and prevent competitive construction, investment bankers facilitated intercorporate stockholding. For example, in the East, the Pennsylvania and the New York Central systems made an agreement to prevent excessive competition under the leadership of the House of Morgan at the end of 1899. According to the agreement, the Pennsylvania purchased substantial amount of stock in "the Baltimore \& Ohio, the Chesapeake \& Ohio, and the Norfolk \& Western." Then Baltimore bought the stock in Reading. Meantime, the New York Central owned stock in "the Lehigh Valley, the Erie, the 
Lackawanna as well as the Reading, and through the Reading obtained an interest in the Central of New Jersey." In the South, Morgan also led the Atlantic Coast line to purchase 51 per cent of the Louisville \& Nashville. In the West, interlocking stockholding of the Rock Island, the Alton, the St. Louis, the Santa Fe and other small roads was arranged by Moore brothers. [406] However, the use of the holding company to restrain competition was finally restricted. When the Northern Securities Company, which owned the stocks of the Great Northern and the Northern Pacific, was formed, the Supreme Court decreed that "holding company might not be used as a means of effecting combinations in violation of the spirit of the Sherman Anti-trust Law.”[407]

Firms also used the holding companies to attain efficiency in production. Largescale production through the holding company, in particular in public utilities, reduced costs relative to output. Also, vertical combination, through which firms secured raw materials and markets to distribute their products, improved throughput, the speed and volume of the flow of materials. [408] Efficiency in vertical consolidation is seen in the case of the United States Steel Corporation, which consolidated various steel related companies.[409]

Decentralization of the administration was another advantage in the use of the holding company. As Bonbright and Means explain, "by maintaining separate branches of an enterprises as separate corporations with separate semi-independent board of directors the management of a concern can conduct it more as a group of federated enterprises than as a single army like organization." [410] The use of the holding company would also minimize the risk of speculative business; the loss made by one 
speculative constituent company would be less influential on other constituent companies. [411]

Finally, the holding company was often the most effective way for combination. While mergers and acquisitions required "a majority (usually two thirds) or unanimous agreement of the stockholders and may involve difficulties with the contractual rights of bondholders as well as the risk of lawsuits by dissenting stockholders," the acquisition of stock control was simpler and less costly through a holding company. [412]

\subsubsection{Financial Roles of the Holding Company}

To obtain control of many constituent companies, the holding company had to own huge blocks of their stocks, but the capital required for this investment was much smaller than funds needed to effect mergers or acquisitions, or to establish a new company. In particular, by forming a pyramid of holding companies, the top holding company could obtain control with minimum investment. Control of many operating companies was obtained by a first-degree holding company through the ownership of the majority of their stocks. The first-degree holding company was controlled by the seconddegree holding company in a similar manner. Thus, the more holding companies were involved in pyramiding, the less the top holding company invested to obtain control of operating companies. If the operating companies or the lower-degree holding companies had bonds or non-voting stock, the investment required in voting stock to obtain control by the top company was further reduced.

The holding company system was financially beneficial for the constituent companies, too; the holding company provided them with financial support and took a permanent investment in their stocks. Since the holding company owned large amounts 
of their stocks, a deterioration of business in those companies would reduce its income and influence the value of its own common stock. To protect its stock and to achieve better business results, it could not ignore the financial condition of the constituent companies. Holding companies would issue their own securities to raise funds for their constituent companies. When the constituent company did not have a "strong independent credit," the holding company often issued collateral trust bonds, which was secured on the constituent company's "stocks, notes and bonds acquired for its treasury." Since it was difficult to assure the value of the collateral, the bankers that underwrote these bonds required that "the collateral shall constitute at least sufficient properties of the outstanding securities as will enable the holders of the bonds to secure possession of the physical property of one or more of the subsidiaries."[413] Only when the constituent company had good independent credit was the holding company able to issue debenture bonds and preferred stock. [414] These issues of huge amounts of securities in the holding company reduced financial costs to the operating company, because holding companies could usually raise funds at a cheaper price due to their strong credit.

Likewise, holding companies guaranteed the bonds of constituent companies. As Arthur S. Dewing explains, the guarantee was often only a temporary expedient. Usually, it stood in line behind the other holding company securities. And holding companies could easily evade responsibility simply by giving a notice to bondholders. In fact, since the value of bonds was determined by "the earning capacity of the physical property or the business good-will of the issuing company," Dewing concluded, most guaranteed bonds were "barely worth the paper they are written on."[415] In spite of the worthless of guarantee bonds, these facilitated the sale of bonds issued by small companies. Investors 
believed in the participation of the large holding companies in bond issues of small companies.

The holding company also advanced funds temporarily to the constituent companies as "unsecured open accounts" or as "loans secured by pledge of securities" of the constituent companies. [416] To secure this large amount of working capital, the holding company sold its own securities or retained its own earnings. When the advance increased to a certain level, the constituent company issued its own securities and used the proceeds to repay their obligation. This short-term financial method was advantageous to the constituent companies. They could obtain temporary finance from the holding company even when the money market was in bad condition. Also, they could avoid piecemeal financing since they could wait until their borrowings became large enough to warrant large issues, and their securities issues were authorized very quickly by the holding company owning a majority of their voting stocks. [417]

Lastly, the holding company was sometimes used for the purpose of capital inflation. It often issued common stock of the operating company to meet its financial needs. When the vast amount of stock of the operating company would not be salable in the market for any reason, the managers of the company set up a holding company, to which the operating company sold its own stock. The holding company financed the purchase by issuing its securities to the public. [418]

\subsubsection{Concentration and the Problems of the Holding Company}

Until the early 1900s holding companies helped concentrate economic activity in the United States. In 1904, as a result of consolidation, more than 80 per cent of the miles of railroads were directly controlled by six groups: the Vanderbilt Group, the 
Pennsylvania Railroad Group, the Morgan Group, the Gould-Rockefeller Group, the Harriman-Kuhn Loeb Group, and the Moore Group. As is seen from these names of the groups, the railroad industry was controlled by prominent financiers and industrialists in the United States. [419]

In the public utility sector, a gigantic telephone company, the American Telephone and Telegraph Company controlled 35 subsidiaries, which accounted for 65 per cent of the total aggregate business in the early twentieth century. [420] Although other public utilities companies were more local in nature, such industries as electric light and gas created networks through consolidation within their localities. [421]

In the industrial sector in the early twentieth century, as John Moody shows, there were 318 important industrial big businesses, which controlled 5,288 plants and factories. Of these, seven greater companies-American Copper Company, American Smelting \& Refining Company, American Sugar Refining Corporation, International Mercantile Marine Company, Standard Oil Company, and United States Steel Corporationcontrolled 1,528 plants. [422]

Despite the growth of holding companies and their managerial and financial advantages, however, the movement of consolidation seemed to be on the wane by World War I. Although holding companies should have been making profits of consolidation equivalent to the value of the stock in the constituent companies, the declining value of industrial stocks reduced their income in the early twentieth century. Meade argues that the holding companies were in general the failure from the financial perspective in the early twentieth century. [423] William Leonard also argues the decline of combination in the railroad industry after the Panic of 1907 had an impact. The Panic terminated the 
combination movement in railroads during the period of prosperity, and the market collapse and difficult financial conditions led many railroad companies to insolvency. [424]

Another problem for the holding companies was the anti-trust movement. From 1901 to 1912, Republican Presidents, Theodore Roosevelt, and his successor, William Howard Taft dedicated their administrations to trust busting and dissolved many consolidations. For example, in 1904, the Northern Securities Company was dissolved, convicted as a violation of the Sherman anti-trust of 1890. [425] In 1911, two big businesses, John D. Rockefeller's Standard Oil Company and James B. Duke's American Tobacco Company were busted up due to the violation of the Sherman Act. Furthermore, in 1914 under the Wilson administration, the Clayton Act was passed, which hampered the development of the holding company system; Section 7 of the Act prohibited corporations that dealt with interstate commerce from acquiring stock in other companies, when competition was diminished by the stock ownership. [426]

\subsubsection{The Holding Company in the United States during and after World War I}

During World War I, anti-monopoly policy seemed to disappear completely in the United States. Wartime mobilization achieved by the War Industries Board and other agencies was contradictory to the model of the competitive economy the Sherman Antitrust Law aimed to preserve. On the contrary, many people participated in the war mobilization regarded cooperation as a "new model for organizing the American Economy." [427] In fact, expansion of companies through consolidation was widely allowed, which led to the emergence of newly giant consolidated companies, such as General Motors Corporation and E.I. Du Pont de Nemours Company. [428] The wartime 
experience also affected the post-war anti-monopoly policy. Although anti-monopoly suits continued in the 1920s, the unfavorable attitude toward big business declined. While the anti-trust policy remained opposed to "horizontal price fixing and market divisions," it accepted vertical consolidation, which aimed to promote efficiency not to achieve monopoly. [429]

Under the new, relaxed anti-trust policy, the holding company system reemerged and reached the heyday. But the holding company's role varied from industry to industry. Unlike the industrial sector, railroads and public utilities were allowed to combine through horizontal consolidations. They were subject to regulatory policies, which affected how holding companies operated in each case.

In the case of railroads, the Transportation Act of 1920 attempted to facilitate consolidation in the railroad in accordance with the plan of the Interstate Commerce Commission. Ironically, the act retarded the growth of the holding companies. The government plan hampered railroad managers' initiative toward consolidation. In addition, new regulations set by the act required approval from the ICC to issue securities for consolidation purposes. This changed the form of holding companies in railroads. To evade the regulation, some railroad companies newly set up pure holding companies; they were free from any regulation imposed on railroad companies. [430]

One of the examples was the Allegheny Corporation engineered by the Van Sweringen brothers. They established a pure holding company, the Nickel Plate Securities Corporation, in order to purchase the New York, Chicago, and St. Louis Railroad (The Nickel Plate) in 1916. In 1923, Securities Corporation sold the stock of the Nickel Plate to other Van Sweringen interests, and the company was dissolved. In the 
next step, the Van Sweringen formed three pure holding companies, the Vaness Company, a personal holding company for the Van Sweringen, the Clover Leaf Company owning the Toledo, St. Louis, and Western Railroad (The Clover Leaf), and the Western Corporation owning the Lake Erie and Western Railroad in 1922. All the assets of the latter two companies were transferred to the Vaness Company and the two companies were dissolved in 1928. Since the Clover Railroad was merged with the Nickel Plate in 1923, the stock of new Nickel Plate was also owned by the Vaness Company. Thus, the control of the three independent railroads was merged into one system. [431]

Furthermore, the Van Sweringen's System expanded through the Nickel Plate's purchase of the stock of the Chesapeake \& Ohio Railway and the Pere Marquette Railway between 1922 and 1925. The stocks of the two companies owned by the Nickel Plate were transferred to a new holding company, the Special Investment Corporation in 1926, and then the stock of the two companies were divided into new holding companies, the Pere Marquette Corporation and the Chesapeake Corporation in 1927. On the other hand, the stock of the Erie and the Pere Marquette, which had been acquired by the Chesapeake and Ohio before, was transferred to the Virginia Transportation Company. In the same year, a new holding company, the General Securities Corporation was formed to control the Chesapeake Corporation, under the control of the Vaness Company. Finally, the Alleghany Corporation was incorporated in 1929 "to bring together the stock of the system already held by the Van Sweringen interests in various railroads and to add to these holdings."[432] The company obtained large interests in the Nickel Plate, the Chesapeake Corporation, and the Erie Railroad Company. [433] Thus, by using the 
holding companies, the Van Sweringens built a huge railroad system without government intervention.

It was the public utility sector that led the resurgence of American holding companies in the 1920s. In the telephone industry, the Willis-Graham Act of 1921, which allowed telephone companies to merge competing telephone companies by exempting them from the restrictions of the Clayton Act, accelerated consolidations in the 1920s. The ratio of Bell System telephones to the total telephones in the United States increased 61 per cent in 1920 through 70.5 per cent in 1925 , to 75.2 per cent in 1930. [434] Also, in electric industry, the economic prosperity after World War I sped up consolidations. Numerous promoters were eager to buy electric utility properties, which could be sold later at higher prices. According to Eli Winston Clemens, the number of electric power holding companies jumped up in the 1920s. Prior to 1900 , there were only 5, and there were 11 in the 1900s, but the number soared to 46 companies in the 1920s. [435]

The rapid increase in the number of the holding companies in public utilities was first explained by financial advantages. Public utilities, especially within the electric power and light industry, required huge amounts of capital to finance. These were highly capital intensive industries using "big” technology. However, their earnings were usually not large enough to finance all their needs because operating companies were allowed by laws and by regulators to have only a limited return on the capital due to the public nature of their business. The holding company could meet the capital demand of constituent companies by passing over the dividends and interest revenues it earned from the stockholding and by distributing proceeds from issues of its own securities to the constituent companies.[436] 
Through pyramids of holding companies, moreover, it was possible to reduce the financial burden of obtaining control over a number of companies. [437] For example, one of the biggest utility group controlled by Samuel Insull included two top holding companies, the Insull Utility Investment, Inc., and the Corporation Securities Company of Chicago. The total investment of these two companies amounted to $\$ 435,700,000$. The two companies directly owned the stock of five great systems-Peoples Gas Light \& Coke Company, Commonwealth Edison Company, Middle West Utilities Company, Public Service Company of Northern Illinois, and the Midland United Company. The total assets of these five companies were approximately $\$ 2,400,000,000$, almost 5.5 times as large as the assets of the top two holding companies. The two Insull holding companies did not even need to own a majority of the voting stock of the five companies. Since their stocks were widely distributed to the public, the holding companies could obtain control with less than half of the total stock of each company. In turn, the five companies also had subsidiaries totaling 152 companies, which meant that two holding companies controlled 152 operating companies through pyramiding holding companies.[438]

Another reason to use the holding company in public utilities was managerial. Bonbright explains that the holding company system would attain "efficiency and economy of centralized management or supervision by an organization of highly skilled experts." [439] Although utilities were fundamentally local business and smaller than railroads, a need for centralized management provided the strong motivations to build a holding company system. On the other hand, decentralized administration through the use of the holding company was also beneficial to public utilities; since utilities were 
essentially local businesses and their properties were distributed in different parts of the country, each unit required its own administration.[440]

Finally, similar to railroads in the 1920s, the holding companies in public utilities were tools to evade government control. Public utility companies often used the pure holding form because regulation from the public service commissions did not affect nonoperating companies. In fact, while local operating companies were subject to the regulation, the transaction between the operating company and the holding company was not fully controlled, since the commission could not examine the books of the holding company.[441]

Thus, holding companies dominated public utilities in the 1920s. They controlled "three-quarter of the electric light and power business." In the gas industry, "16 systems controlled $45 \%$ of the gas output." In the telephone industry, one company, A. T \& T, dominated "all except a small fraction of the business." [442]

\subsubsection{Pure Holding Company versus Parent Company}

One prominent feature of the holding companies in the 1920s was more frequent use of the pure holding company form. According to Bonbright, writing in 1940, of the large companies formed after 1920, eight were pure holding companies, and sixty-two were parent companies. But of those formed since 1920, thirteen were pure holding companies, and only one was a parent company. [443] This change was explained by the fact that the use of holding companies was shifted from railroads to public utilities. Railroads, which consolidated into six systems in the early twentieth century, used parent companies. The railroad parent companies were engaged in operation as well as control other parts of lines through stock ownership. On the other hand, public utilities, which 
adopted holding companies more often in the 1920s than before, frequently used pure holding companies.

Bonbright and Means, writing in 1932, attributed the different types of holding companies in railroads and public utilities from each other to "the more recent development of the utility business," "the relatively small size of each utility operating unit," and "the freedom from financial control enjoyed by the railway operating companies prior to the Transportation Act of 1920." [444] When railroads began to develop in the last half of the nineteenth century, corporations were not allowed to hold the stock of other companies without a special act of a state legislature. The legislature usually granted the power of stockholding to an operating company rather than a pure holding company. When the general corporation laws permitted the use of the holding company in many states, the corporate structure of the railroads had already been fixed.[445] Although state laws allowed the formation of holding companies, the pure holding company did not seem to be widely accepted in the early twentieth century; the Northern Securities Company, which was dissolved in 1904 due to the violation of antitrust-laws, was a pure holding company.

The size of the operating unit is another important factor. Railroads tended to grow into large centrally operated systems to achieve efficiency in transportation. In contrast, in public utilities, each operating unit was smaller and often geographically separated from other unit so that the link between public utilities companies was less tighter than that of railroads. This loose combination in public utilities could be attained by pure holding company, in which operation of the constituent companies were decentralized. [446] 
Lastly, federal control affected the use of the holding companies. Before the passage of the Transportation Act of 1920, without serious restrictions on the railroad companies, the companies had no need to use pure holding companies to evade regulation. Meanwhile, public utilities, which expanded rapidly during the 1920s, were subject to regulation because of their public nature of the services they provided. [447]

As public utilities used pure holding companies more than parent companies and played more significant roles as financial intermediaries of their constituent companies than before, the difference between investment companies and holding companies blurred in the 1920s. Holding companies issued their own securities backed by securities of their constituent companies. They also held various stocks in a large number of the constituent companies and planned diversification of their investment. These financial activities were analogs to those of investment trusts, which held the stock of many other companies for the purpose of financial portfolio diversification. Although, in a broad sense, investment trusts were classified as pure holding companies, in a usual sense, holding companies, which primarily aimed to control or influence the management of the certain companies, were not investment trusts. [448]

\subsubsection{Securities Market and Banks versus Holding Company}

The holding companies needed enormous amounts of funds to purchase shares and bonds of constituent companies and often to advance short-term funds to them when needed. They primarily meet these financial needs by bonds of their own. Railroad holding companies mainly used mortgage bonds with the lines of the constituent companies serving as collateral. They also used collateral trust bonds secured by the stocks and bonds of constituent companies. Public utility holding companies also relied 
on collateral trust bonds. Since they did not have properties suitable to issue mortgage bonds, they could not issue mortgage bonds. To a lesser extent, industrial holding companies used collateral trust bonds, too. Although compared with railroads and public utilities, industrial companies were reluctant to issue bonds due to the unstable demand of their products, large industrial holding companies used collateral trust bonds. Responding to the demand for bond issues, investment bankers played a role in underwriting these bonds, considering that these were safe investments secured by sufficient collaterals.

Holding companies also used common stock to raise funds. The stock was in general widely held in the public. The Pennsylvania Railroad, the American Telephone \& Telegraph, and the United States Steel examined in Chapter One were holding companies that distributed their stocks widely in the public in the 1920s. These stocks were often allocated to the existing shareholders, but the number of shareholders increased in part due to the convertible bonds and in part due to the sale of the stocks by the existing shareholders through the securities markets. According to Berle and Means, these companies achieved managerial control through the dispersed stockownership.

However, not all holding companies attained concentration of control in the same manner as these three companies. As Berle and Means show, in 1930, the companies that attained managerial control through the dispersion of stockownership were 62 per cent in railroads, 38 per cent in public utilities, and 40 per cent in manufacturing of the 200 largest corporations. [449] In fact, some holding companies separated ownership from control through pyramiding holding companies. For example, as a result of the pyramiding, Van Sweringen's interests represented only 8 per cent of the capital of Alleghany Corporation and 4 per cent of the Chesapeake Corporation. [450] 
Another method was the manipulation of right to vote. The Cities Service Corporation, a pure holding company of public utilities, sold million shares of a preferred stock with a $\$ 1$ face value to H.L. Doherty and Company, one-man company of the president of the Cities Service, H.L. Doherty. Each share of this cheap preferred stock was entitled to one vote, while each share of common stock was entitled to only $1 / 20$ vote. Thus, through the ownership of the preferred stock, Doherty secured 27 per cent of the votes, which was enough to provided him with control power over the Cities Service, since the other class of stock were widely held in the public. As a result, " a million dollar par value of stock held virtual control over assets of approximately a billion dollars.’[451]

Still other companies used voting trust to concentrate control without ownership. For example, the Pennsylvania Railroad used this method to form its pure holding company, the Pennroad Corporation. The Pennsylvania Railroad placed the stock of the Pennroad in a voting trust, and offered voting trust certificates to its existing shareholders. The investors of the certificate did not have any power to control the company. [452]

The public utility sector, which actively adopted the holding companies in the 1920s, used these devices—pyramiding, voting right, and voting trust. Berle and Means show that managerial control achieved by these devices accounted for 36 per cent of the largest holding companies. [453] Thus, in distributing stocks widely in the public, corporate finance among the holding companies was closely associated with the securities market. 


\subsection{The Holding Company in Japan}

\subsubsection{Zaibatsu and the Holding Company}

Zaibatsu were corporate groups whose capital was concentrated in families. Making the best use of the closely owned capital, they accumulated funds and achieved diversification. While in the United States families such as the Rockefellers and the Du Pont were concentrated on specific industries, zaibatsu families extended their activity toward almost all kinds of business. [454] This is in part explained by the much smaller size of Japanese market than that of the United States. Big businesses of the United States attained economies of scale by forming combinations. However, in the small Japanese market, there were fewer opportunities to achieve economies of scale. Instead, the national policy to catch up with western economy and the lack of experience in foreign trade with western countries led Japanese businessmen to another kind of consolidation. To smooth business activity, zaibatsu families were eager to control companies belonging to wide array of manufacturing industries and services specialized in foreign trade, shipping, insurance, and finance. Interestingly, the Japanese zaibatsu was quite similar to family industrial groups in Belgium, which emerged in the last half of the nineteenth century. Belgian industrial groups were also based on families. Various industries included in the industrial groups were organized through the holding company system, in which a family-owned holding company was at the top. [455]

\subsubsection{Early History of Zaibatsu and the Holding Company System}

Zaibatsu emerged after the Meiji Restoration. According to Hidemasa Morikawa, their emergence was associated with government patronage and loans often associated 
with the mining business. In the Mitsui and the Mitsubishi group, "traders and financiers who had their strong ties to powerful political figures," called seisho in Japanese, accumulated their wealth by obtaining "subsidies, grants of monopolies or special privilege, favorable credit arrangement and sale of state enterprise at nominal prices."[ 456] For example, the Mitsui group as a financial agency of the Meiji government was allowed to utilize government funds deposited with them without paying interest. Through the privilege, the Mitsui group made profits large enough to establish one of the biggest private banks, the Mitsui Bank in 1876. With using ample funds from the bank, Mitsui engaged in diversification. [457]

The Mitsubishi group also developed as zaibatsu under the government support. Yataro Iwasaki, the founder of the Mitsubishi zaibatsu, had been associated with the management of Kyujukyu \& Co, the trading company owned by the feudal domain of Tosa. In 1873 after the domain of Tosa collapsed during the Restoration, he established Mitsukawa \& Co., using the ships that were bought from the domain of Tosa. The company was soon renamed the Mitsubishi \& Co. Its business developed along with the government protection of shipping industry. Although the Mitsubishi group finally retreated from shipping when their business was merged into the Nihon Yusen Co. Ltd. in 1886, the Mitsubishi group turned to a new business, shipbuilding. It purchased the Nagasaki Shipyard from the government for a nominal price by using the wealth accumulated in shipping. After Japan's victory in the Sino-Japanese War, benefiting from large-scale subsidies to the industry, shipbuilding became one of the leading industries in the Mitsubishi group and facilitated diversification in the related industries. [458] 
Mining helped to establish other zaibatsu. In particular, the Sumitomo group diversified its business, relying on the Besshi Copper Mine. Although the family set the policy to specialize in the mining business, opposing to diversification in 1868 , the stability of the management in the Besshi Mine ironically led them to various businesses such as banking, trading, shipping, and silk reeling. [459] To a lesser extent, the Mitsui and the Mitsubishi groups also benefited from mining. They purchased mines owned by the government, the Miike Coal Mine and Takashima Coal Mine respectively. The success in the management of these mines brought about enormous funds to support diversification of family businesses. [460]

The existence of these family-owned businesses was secured by kaken, which literally means family constitution in Japanese. The kaken was an unofficial moral code that imposed no legal obligation, but it played a significant role in maintaining family business. It differed by family group. In the Mitsui group, according to the principles made by Takahara Mitsui, the founder of the Mitsui Zaibatsu, the membership of the Mitsui business was limited to the family in order to "avoid a dispersal of assets and loss of consensus within the family."[461] Also, the members were not allowed to dispose of assets, borrow money, or guarantee other people's loans. These rules made the Mitsui organization more "corporate" and less "partnership" in American terms. In the United States, partners can do just these things-borrow money or obligate the firm in some way without necessarily getting the consent of a central authority.

Similarly, in the Sumitomo group, its family constitution emphasized family management under the cooperation between the main family and the branch families, and the control of the main family over the family business, aiming at the preservation of 
family property and at the stability of family business. [462] On the other hand, the Mitsubishi group did not have any stated family constitution, but the rule to avoid the dispersion of family property was set in 1907; the heads of two families, Yataro Iwasaki and his brother Yanosuke Iwasaki, and their heirs alone could be investors of the headquarter of the Mitsubishi group, Mitsubishi Ltd. [463]

\subsubsection{The Holding Company before World War I — The Case of Mitsui and Mitsubishi}

\subsubsection{Diversification - the Case of the Mitsui Group}

After the late nineteenth century, zaibatsu families further diversified their businesses. However, unlike in the United States, the holding company system was not fully developed in the early twentieth century. In the Mitsui group, the Mitsui Omotokata, the administrative institution of the Mitsui family business, was not an incorporated entity, but it had 100 per cent ownership of its two key affiliates for managerial centralization, the Mitsui Bank and the Mitsui Trading Company. These companies played a significant role in promoting diversification. The Mitsui Bank contributed diversification, especially before the early twentieth century. It was established with capitalization of $¥ 2$ million, of which $¥ 1$ million was owned by the Mitsui Omotokata, $¥ 500,000$ by the Mitsui families, and $¥ 500,000$ by its employees. [464] In other words, the bank was not exclusively owned by the family, but its stock was still closely held. The bank facilitated diversification under the industrialization policy made by a powerful manager, Hikojiro Nakamigawa, in the turn of the nineteenth century. [465] It gained control of the Kanebuchi Spinning Company and the Oji Paper Company by increasing

its stockholding of these companies in the 1890s. It also acquired Shibaura Engineering 
Works, Maebashi Silk Spinning Mill, and Oshima Silk Filature when they were defaulted on the Bank's loans. Furthermore, it purchased two silk mills from the government and built two another silk mills by itself. Finally, the Bank actively invested in the mining business. It provided the Mitsui Mining Company with funds for the technological improvement and the purchase of mines. Thus, the Bank's shareholding and lending was concentrated on Mitsui affiliates. [466]

However, the industrial policy of the bank was drastically changed after the death of Nakamigawa in 1901. Takashi Masuda, another businessman in the Mitsui, spun off Shibaura Engineering Works. Away from financial support from the Mitsui group, the company entered the joint venture with General Electric in 1905. Masuda also sold all silk mills and filature, being anxious about the risks of financing manufacturing. [467] He also restrained the lending of the Bank to Mitsui constituent companies. After Masuda's new financial policy, the bank rather focused on commercial banking; it mostly made short-term loans to commerce and raised funds from interests, away from industrial finance.

The Mitsui Trading Company, called the Mitsui Bussan, was founded at the same time as the Bank in 1876. It was a general trading company (sogo shosha), dealing with a various services and commodities. The sogo shosha was a product of the modernization of Japan. Since Japan had been isolated from international economy for three centuries due to the national policy during the Tokugawa Period, it had had few experiences with foreign trade. To participate in it, Japanese businessmen needed to organize trading companies that would have special knowledge to deal with shipping, foreign exchange, and insurance. The trading companies implemented all the services required for foreign 
trade. The general trading companies also helped to keep the price of Japanese products competitive by providing economies of scope in distribution. [468] Since the Mitsui family regarded trading as risky, the Mitsui Trading Company was formed by two members of the branch families separated from the main Mitsui family, Tekenosuke and Yanosuke Mitsui. The company had no capital except a loan contract of $¥ 50,000$ with the Mitsui Bank. [469] Although the company was not likely to prosper in the beginning, it came to play a significant role in the diversification of the Mitsui business. As its business expanded to various fields, it was put under the supervision of the Mitsui Omotokata, and its capital increased to ¥1 million in 1893 .

The managerial strategy of the company was to obtain monopoly in distribution as a sole agency, but not to control all production itself. [470] For example, it often financed the funds of expansion of the Mitsui Mining and paid for 80 per cent of proceeds of coal in advance in order to obtain a right as a sole agency of the coal products of the company. It also provided loans to the Onoda Cement Company for the same purpose in 1901 . The two companies were connected by the Mitsui Trading Company; it sold coal purchased from the former to the latter. [471] As another example, the Mitsui Trading Company dealt with all process of cotton yarn industry. The company provided preference in terms of exchange, rebates for commissions, and credit for the purchase of raw cotton to the spinning companies. It obtained the right to be a monopolistic supplier of raw cotton, and it also became a sole agency of export of the finished product of spinning companies, cotton yarn, to the international market. The export of cotton yarn was also closely related to other fields - the import of spinning machinery and the coal business. Thus, the 
Mitsui Trading Company dealt with all of the process from raw material through source of power to semi-finished and finished products. [472]

Although diversification in the Mitsui group progressed, the innovation of the corporate form was gradual. The legal basis of the holding company system was the new Commercial Code implemented in 1893. It established three commercial entities: unlimited partnership (gomei kaisha), limited partnership (goshi kaisha), and joint-stock companies (kabushiki kaisha). In 1893, the Mitsui Bank and the Mitsui Trading Company were reorganized as gomei kaisha. The Mitsui group avoided adopting the joint-stock company form because it required disclosing financial information of the company. But limited partnership seemed more desirable than unlimited partnership. In fact, the Mitsui group sought limited liability at first. The thing that changed its decision was the content of the Commercial Code; it stated that when the employee had the last name same as the trade name of the company, he had unlimited liability. In other words, so far as the company was named the Mitsui, the family members were not exempted from liability. At last, considering the confidence of the general public in the Mitsui business, the Mitsui group decided to choose unlimited partnership. [473]

Finally, the Mitsui group reorganized the central institution of the family business, the Mitsui Dozoku-Kai in 1909. [474] The concerns to maintain family properties safely through unlimited liability and to protect the secrecy of family business had hampered the change of the corporate form in accordance with the Commercial Code. The reorganization was promoted in reference to the advice of Max Warburg, the head of the M.M. Warburg \& Co., Hamburg, Germany, and to the holding company system in the United States. According to Warburg, the Mistui Dozoku-Kai should be 
reorganized as a pure holding company, and the three direct affiliates would be changed to joint-stock companies. The holding company would maintain control over them by holding at least 51 per cent of their stocks. Warburg's advice suggested the formation of monopoly of the Mitsui business. Although in Germany, the holding companies were mostly applied to international industries rather than domestic ones due to "the more limited use of stock company," and "legal regulation and government supervision" over the corporate activity before World War I, the holding company was widely applied when "monopoly was the main object of combination." [475] Warburg's idea was carried out after the manager of the Mitsui business, Takashi Masuda, saw in 1907 the holding company system in the United States Steel Corporation. He believed that the organization of the holding company would be helpful for the reorganization of the Mitsui group.[476]

Thus, the Mitsui Gomei Kaisha was established in 1909, of which 11 families of the Mitsui group were the members. The adoption of the unlimited partnership form would protect the secrecy of financial and other matters of the Mitsui Gomei. At the same time, the Mitsui Bank and the Mitsui Bussan became joint-stock companies. In 1911, the mining department of the Mitsui Gomei was spun off and became a joint-stock company. Without this method, the loss of a constituent company would directly affect the Mitsui Gomei and other constituent companies, since the Mitsui Gomei, which held all of the stocks of these constituent companies, took the form of unlimited partnership. [477] Thus, the reorganization in 1909 established the system which consisted of the central institution, the Mitsui Gomei, and major direct affiliates, the Bank, the Trading Company, and later the Mining Company. Through the adoption of the holding company system, the Mitsui group was able to attain administrative centralization. At the same 
time, family-based monopolistic business system was sustained not only by unofficial family code but also by the commercial law. [478]

\subsubsection{The Financial Role of the Holding Company — the Mitsui Gomei Kaisha}

Similar to the Dozoku-kai, the Mitsui Gomei was financed by family funds. Technically, owners of the Mitsui Gomei were family members, but that does not mean the funds came from them. The capitalization of $¥ 50,000,000$ (equivalent to $\$ 25,000,000$ ) of the Mitsui Gomei was all financed by retained earnings in the Dozoku-kai and the three direct affiliates: $¥ 20,000,000(\$ 10,000,000)$ from the Mitsui Bank, $¥ 20,000,000$ $(\$ 10,000,000)$ from the Mitsui Trading Company, $¥ 2,000,000(\$ 1,000,000)$ from the Mitsui Mining, and $¥ 8,000,000(\$ 4,000,000)$ from the Dozoku-kai.[479]

As a holding company, the Mitsui Gomei accumulated funds, including the capital financed by the Dozoku-kai and the three direct affiliates and dividend income through stock ownership of the constituent companies. These funds were redistributed to the direct affiliates and other constituent companies mostly in the form of stockownership. In 1910, gross assets of the Mitsui Gomei was $¥ 70,090,000$, (equivalent to $\$ 35,045,000)$ of which $¥ 44,040,000(\$ 22,020,000)$ was invested in the securities of direct affiliates, the constituent companies, and others.

Most of the funds the Mitsui Gomei accumulated were distributed to the direct affiliates because the Mitsui Gomei owned all of their stock. When the Mitsui Bank and the Mitsui Trading Company were reorganized as joint-stock companies, total capitalization of each company, ¥20,000,000, was all owned and paid in by the Mitsui Gomei. Also, when the Mitsui Mining was separated from the Mitsui Gomei, total capitalization of $\$ 20,000,000$ was all owned by the Mitsui Gomei, of which $\$ 5,000,000$ 
was paid in.[480] In fact, in 1910, the stock of the Mitsui Bank and Mitsui Bussan accounted for more than 92 per cent of the securities of the Mitsui Gomei held. [481] Similarly, in 1912, more than 90 per cent of stock owned by the Mitsui Gomei was the three direct affiliates’, $¥ 20,000,000$ of Mitsui bank’, $¥ 20,000,000$ of the Mitsui Trading Company’s, and $¥ 5,000,000$ of the Mitsui Mining’s. [482]

\subsubsection{The Case of the Mitsubishi Group}

The Mitsui group was the first zaibatsu to reorganize diversified businesses by adopting the holding company system. In contrast, the Mitsubishi group founded the Mitsubishi Goshi Kaisha in 1893 according to the Commercial Code. It was capitalized at $¥ 5,000,000$, which Yanosuke and Hisaya Iwasaki provided. [ 483 ] However, this reorganization did not lead to the use of the holding company system. Until 1917 when the Mitsubishi group set the rule to clarify the relation between the Mitsubishi Goshi and its direct affiliates, it had relied on the divisional organization; unlike the holding companies, the Mitsubishi Goshi held many departments, which were not independent companies. [484] For example, the bank department of the Mitsubishi Gomei received $¥ 1,000,000$ from the head office of Mitsubishi Goshi and its management was always controlled by it. The mining and the shipbuilding departments also received $¥ 15,000,000$ and $¥ 1,000,000$ respectively from the head office.

The Mitsubishi Goshi was not able to finance its diversification by itself. Its major income was a portion of the profits each department made. [485] Although the funds were accumulated in the Mitsubishi Goshi, they were not large enough to afford rapid expansion of the businesses. To supplement the lack of funds, the company relied on individual contributions from the family. As Morikawa explains, Hisaya Iwasaki lent 
funds from $¥ 700,000$ in 1894 to $¥ 8,900,000$ in 1906 . Also, his equity in the Mitsubishi Goshi’s reserves rose to $¥ 10,700,000$. [486] Unlike the Mitsui group, the Mitsubishi did not set up the holding company system, and its finance counted on individual family members before World War I.

\subsubsection{The Holding Company in Japan during and after WWI}

\subsubsection{The Expansion of Zaibatsu}

During World War I, Japan experienced the unprecedented economic growth through the development of various manufacturing industries. Needless to say, the leading zaibatsu, which contributed the economic development at that time, accumulated capital and expanded their business not only by enlarging investments in their existing constituent companies but also by extending their investments in the newly developing industries, such as steel, iron, chemicals, and electrical industries. [487]

The Mitsui Gomei increased its capital from $¥ 50,000,000$ to $¥ 60,000,000$ in 1914 , in part to pay the rest of the capital of the Mitsui Mining. [488] During the economic boom right after the war, the capital of the Mitsui Gomei reached ¥200 million (equivalent to $\$ 100$ million). This huge increase was closely tied with the increase in the capital of the direct affiliates. The capital of Mitsui Bank rose from $¥ 20,000,000$ $(\$ 10,000,000)$ to $¥ 1,000,000,000$ ( $\$ 500,000,000)$, that of the Mitsui Trading from $¥ 20,000,000(\$ 10,000,000)$ to $¥ 1,000,000,000(\$ 500,000,000)$, that of the Mitsui Mining from $¥ 200,000,000(\$ 100,000,000)$ to $¥ 500,000,000,(\$ 250,000,000)$, and that of the Toshin Warehouse from $¥ 2,000,000(\$ 1,000,000)$ to $¥ 5,000,000$ ( $\$ 2,500,000)$. The Mitsui Gomei as a holding company owned all of the newly issued stocks except a part of the stock of the Mitsui Bank. The total increase in the capital of the four direct affiliates 
amounted to $¥ 1,930,000,000(\$ 965,000,000)$, of which $¥ 1,500,000,000(\$ 750,000,000)$ was paid-in. In addition, as the war introduced the growth of existing and new industries, the Mitsui Gomei extended its business by purchasing stocks of companies such as the Hokkaido Colliery Railway, the Kanebuchi Spinning, and the Denki Kagaku Kogyo Company (Electrical chemistry). [489]

In 1917, the Mitsubishi group adopted the holding company system. The divisional organization could no longer finance the expanding businesses. The departments in the Mitsubishi Goshi came to be independent companies, and the Mitsubishi Goshi became a holding company, controlling the newly established companies. In 1917 the Mitsubishi Shipbuilding was incorporated with capitalization of $¥ 5,000,000$, Mitsubishi Steel with $¥ 30,000,000$, the Mitsubishi Warehouse with $¥ 10,000,000$, and Mitsubishi Trading with $¥ 15,000,000$; in 1918, Mitsubishi Mining with $¥ 50,000,000$ and Mitsubishi Marine with $¥ 5,000,000$; in 1919 Mitsubishi Bank with $¥ 50,000,000$, Mitsubishi Internal Combustion Engine Manufacturing with $¥ 5,000,000$, the Mitsubishi Electric with $¥ 15,000,000$, and Mitsubishi Trust with $¥ 30,000,000$; and finally, in 1927,the Mitsubishi Oil with $¥ 1,5,000,000$. To help finance the establishment of these companies, the Mitsubishi Goshi’s capital increased from $¥ 30,000,000$ in 1918 to $¥ 120,000,000$ in 1922 . [490]

\subsubsection{Financing the Expansion of Zaibatsu}

Thus, the two major zaibatsu established the holding company system, in which the holding company took the form of a limited or unlimited partnership, and the constituent companies were joint-stock companies. Another major zaibatsu, the Sumitomo group also took a form of unlimited partnership. The holding company system 
continued to expand through accumulated profits and family funds during and after the war. In the case of the Mitsui Gomei, the increase in capital was financed by the funds that its direct affiliates accumulated during the war and paid to the Mitsui Gomei. [491] In particular, the Mitsui Gomei received special dividends equivalent to the increase in the capital of the key direct affiliates, the Mitsui Bank, the Mitsui Trading and the Mitsui Mining. In the Mitsubishi Goshi, its capital was owned within the family; Hisaya and Koyata Iwasaki owned $¥ 90$ million and $¥ 30$ million of shares respectively in 1922.[492]

However, the expansion of these zaibatsu was too rapid to finance internally over the longer term. Public offerings of stocks in part helped the holding companies reduce their financial burden for the expansion of the constituent companies. In the Mitsui group, the Mitsui Bank, which came to have a huge financial demand, was allowed to offer 300,000 shares to the public out of 800,000 newly issued shares in 1919. [493] In the Mitsubishi group, Mitsubishi Mining offered 400,000 shares in the public in 1920. In 1929, the Mitsubishi Goshi also offered 235,000 shares in the public.

It is interesting to note that public offering at that time did not necessarily mean that zaibatsu families were eager to distribute the shares of their holding and constituent companies widely in the general public. In fact, the companies often offered their stock to their associates; the employees and directors of their holding companies and other companies within the group or the clients of the company. For example, in the Mitsui Bank's public offering in 1919 , more than 70 per cent of the shares offered in the public were subscribed by its important clients and depositors of the bank.[494] As another example, in Mitsubishi Mining's public offering in 1920, the associates of the company 
had priority to the assignment of the shares. [495] Through this method, zaibatsu attempted to limit the rights of shareholders.

Another method to raise funds was mutual stock ownership; one constituent company held stock of another within the same zaibatsu. On one hand, mutual stock holding reduced the financial burden of the holding company. On the other hand, the control over the constituent companies remained inside the zaibatsu. In the Mitsubishi group, the major affiliates heavily used this scheme; 1,000 shares were mutually held between the Mitsubishi Shipbuilding and the Mitsubishi Steel, between the Mitsubishi Shipbuilding and the Mitsubishi Warehouse, between the Mitsubishi Steel and Mitsubishi Warehouse, between Mitsubishi Mining and the Mitsubishi Trading and between Mitsubishi Trading and the Mitsubishi Bank from 1918 to 1919. [496]

Even without mutuality, the major affiliates often supported the holding company in financing the other constituent companies. In particular, Mitsubishi Shipbuilding, one of the oldest and biggest direct affiliates of the Mitsubishi Goshi, was the largest shareholders of the Mitsubishi Electric and the Mitsubishi Internal Combustion Engine Manufacturing in the early 1920s. Mitsubishi Trading was also a major shareholder of Mitsubishi Electric at that time. [497]

Finally, zaibatsu introduced foreign capital for some constituent companies, although its purpose was to allow Japanese firms obtain technology licenses not to raise funds from foreign countries. [498] Even before 1914, zaibatsu participated in joint ventures. Especially in the Mitsui Group, there were three joint ventures; between Tokyo Electric and General Electric (U.S.) in 1905, Japan Steel Products and Vickers and Armstrong Whitworth (U.K.) in 1907 and Babcock \& Wilcox (U.K.) and Mitsui Trading 
Company in 1908.[499] Between 1914 and 1931, the use of foreign capital (and foreign technology) in zaibatsu groups seemed to be further accelerated. In the Mitsubishi group, the first joint venture was carried out between Toyo Electric and English Electric (U.K.) in 1917. In 1923, the Mitsubishi Electric Company, which was separated from Mitsubishi Shipbuilding and incorporated in 1921, made a contract of technology affiliation with the Westinghouse Company (U.S.). At that time, 30,000 shares out of total issue 300,000 shares of Mitsubishi Electric were transferred to Westinghouse. Since par value of the share was $¥ 50$, the total capital transferred amounted to $¥ 1,500,000$, of which Westinghouse received $¥ 1,000,000$ for nothing and paid $¥ 500,000$ only. [500] Also, Mitsubishi Oil Company was formed as a joint venture with the Associated Oil Company in the United States in 1931. Mitsubishi, including Mitsubishi Goshi, Mitsubishi Trading, and Mitsubishi Mining on one hand and the Associated Oil on the other owned a half of the capital respectively. The joint venture aimed to "obtain technological assistance", "train Japanese to run the operations, and "furnish crude oil." [501] The introduction of facilities and technology of oil refining in addition to the importation of crude oil was necessary due to the underdeveloped refining technology and the lack of oil resource in Japan. [502] Similarly, in the Sumitomo group, there were four joint ventures with the U.S and U.K companies from 1914 to 1931.

\subsubsection{The Holding Company and the Role of the Bank}

The expansion of the holding company system was associated with the declining role of banks in corporate finance. During and immediately after World War I, the Japanese banking business grew rapidly as the economy boomed. The Mitsui Bank increased capital from $¥ 20,000,000$ to $¥ 100,000,000$ in 1919, the Mitsubishi Bank from 
$¥ 50,000,000$ to $¥ 100,000,000$ in 1920 , and the Sumitomo Bank from $¥ 15,000,000$ to $¥ 30,000,000$ in 1917 . However, the expansion of the zaibatsu banks did not necessarily support the companies belonging to the same zaibatsu. In the Mitsui group, as explained above, the Mitsui Bank was no longer active in financing long-term funds in industries after the 1900s. In the early 1920s, Mitsui Gomei and its direct affiliates could finance themselves without the support from the bank. Even other constituent companies did not need large amounts of funds; they relied on the Bank only 6.8 per cent of its total capital. The money was abundant because huge profits made during the war had no way to be disposed under the post-war recession in the early 1920s. [503] Similarly, the Mitsubishi group minimized lending by the Mitsubishi Bank to the constituent companies in the 1920s, even though the Mitsubishi Trading Company still relied on the bank. The isolation policy of the banks from the constituent companies was explained in part by the intention of zaibatsu families to "eliminate the common impression that its bank was the private possession of the zaibatsu."[504]

Instead of financing within the zaibatsu, the idle capital of the banks turned to outside zaibatsu. Especially, the banks were actively involved in electric utility finance. Although their ownership of electric utilities was negligible, they made huge amounts of loans. For example, the amount of loans to the electric utilities of the Mitsui Bank, which was the most aggressive in electric utility finance among the zaibatsu banks, amounted to $¥ 99.5$ million.[505] The banks also began to underwrite electric utility bonds. In particular, the Mitsui Bank dealt with huge amounts of bonds in the Tokyo Electric Light and Toho Electric Power Companies. From 1924 to 1932, it underwrote 17.7 per cent of 
all the electric utilities bonds issued, and assigned these bonds to other financial institutions and the associates of the Mitsui. [506]

Unlike the holding company, the Mitsui Bank did not aim to obtain control, but to protect its credit. It often tried to collect loans by having electric utility companies issue foreign bonds as alternative financial sources. For example, the Tokyo Electric Light Company issued Sterling bonds for the first time in 1923, in part to repay loans to the Mitsui Bank, although the company failed to do so due to the special contract with the British underwriter, which limited the maximum amount of the bonds issued to half of the paid-in capital. Until 1928, the company was forced to rely both on foreign bonds and bank loans as a result of financial difficulty. In 1928, however, the Mitsui bank successfully collected a large amount of repayment through the Tokyo Electric Light's huge bond issue. Recognizing the availability of the use of foreign bonds to refund its loans, the Mitsui Bank could continue to make loans to the company. In the case of the Toho Electric Power, another utility company with which the Mitsui bank was associated, the balance of loans for the bank was inversely proportional to foreign bond issues. [507] Thus, as the holding company system expanded, the activity of the zaibatsu banks were extended to outside the zaibatsu, but they seemed to aim at financial gains rather than at obtaining control power over the companies they supported to finance.

\subsection{Conclusion}

Both in the United States and Japan, holding companies were primarily formed for managerial purpose; they sought monopolistic power and managerial advantage. In the United States, the holding companies achieved concentration of power with a small quantity of capital. As a result, some firms attained large-scale economies (large 
industries), others took advantage of the use of talented staff in the administration of constituent companies (public utilities), and others enjoyed economies of network and system (railroads, telephones, and electric utilities). Meanwhile in Japan, adopting the holding company system, zaibatsu maintained the monopolistic power of family business. They also achieved administrative centralization and operational decentralization; while the close ties between the head office and key firms such as a bank and a trading company strengthened the financial and administrative controls within the zaibatsu, the loose ties between key firms and other constituent companies made it possible to control diversified businesses.

Although holding companies were established primarily for managerial purposes, they played a significant role in financing group companies in both the United States and Japan. However, the way they raised funds for that purpose differed from nation to nation. In the United States, in the formation of the holding company system, the securities market was an important source of funds. Holding companies were able to distribute their stocks widely to the public by using such methods as pyramiding, voting rights, and voting trusts. The role of the banks was underwriting the securities of holding companies. The use of the banks facilitated foreign investment in the U.S. holding companies. Before World War I, banks were often an influential in management, but their financial activity was not primarily aiming to obtain control of the firms.

In Japan, on the other hand, the role of the securities market for zaibatsu was less significant. The funds required for the constituent companies in zaibatsu were usually financed by head office of zaibatsu (holding companies), by leading companies in zaibatsu, which accumulated ample funds from profits, or by mutual shareholding within 
zaibatsu. Even when outside funds were needed, zaibatsu often used private subscriptions. Zaibatsu also used foreign capital for some constituent companies, although its purpose was to obtain advanced technology from foreign countries. The role of banks should not be exaggerated. Unlike main banks in post-World War II keiretsu, the banks within zaibatsu were reluctant to be involved in zaibatsu finance. Their funds were rather directed to outside zaibatsu. Especially, in the 1920s, they made loans and underwrote the securities of electric utility companies. 


\section{Chapter 5}

\section{CONCLUSIONS}

The paths of the development in financial institutions in the United States and Japan were quite different from each other. In the United States, financial institutions were characterized by the fragmented banking system and the development of the securities market. These resulted from a political culture of anti-monopoly and the huge financial demands of private railroad companies from the middle of the nineteenth century. On the other hand, Japan, in the chaos after the Meiji Restoration, created a centralized banking system under the leadership of the government in the 1880 s, while the lack of the accumulation of capital also led to the establishment of the securities market at the same time. Thus, the different timing of industrialization and different political culture resulted in different financial institutions in each nation. According to the notion of path dependency, financial institutions created distinctive corporate financial practices - in this case, the reliance on equity finance in the United States and on bank loans in Japan. These national patterns of corporate financial practices were also demonstrated in the two classics, Berle and Means' Modern Corporation and Private Property for the United States, and Gerschenkron's Economic Backwardness in Historical Perspective for Japan. Berle and Means showed that the size of corporation was an important factor to determine financial practices, while Gerschenkron argued that the timing of industrialization led to different financial practices.

This theory of the national patterns emphasized distinctive patterns of corporate financial practices in each nation. However, comparing corporate financial practices of large corporations in the United States and Japan, this study demonstrated similarities as 
well as differences in the two nations. In the railroad industry before World War I, both U.S. and Japanese companies relied on securities. The securities of the railroad companies in both nations were distributed through personal connections. In the United States, investment bankers played a significant role to provide investors with confidence in the securities they dealt with, and in Japan, leading businessmen contributed the distribution of the stocks in a similar way. This is in part explained by the immaturity of the securities market at that time. Market failure caused by asymmetry of information in the securities market might cause the reliance on mediators between companies and investors.

The differences in railroad finance between U. S. and Japan also existed. The former used mainly bonds and the latter stocks. This national difference was in part caused by the size of the railroad industry and in part by the degree of the development in the securities markets. In the United States, the size of railroad companies was large due to the gigantic geographic scale in the nation; they needed to rely on bond in addition to stocks to meet their huge financial demand. In Japan, on the other hand, the scale of railroad companies was large relative to other Japanese companies, but it was much smaller than that of U. S. railroad companies. Hence, equity finance was able to meet the demand of Japanese railroads. In addition, compared with stock markets, bond markets were underdeveloped before World War I in Japan.

Another difference between the two nations lay in the use of foreign capital. While U. S. railroads obtained huge amount of capital through foreign bond issue, Japanese railroad companies were not able to utilize foreign capital because major Japanese railroad companies, which could obtain credit from foreign investors, were 
nationalized in 1906 before the Railway Collateral Laws and the Collateral Bond Trust Law were passed.

Similar to railroads, public utility finance in both nations relied on securities, although U. S. companies used mainly bonds and Japanese ones stocks before World War I. The difference in corporate financed was obscured when financial demand of Japanese electric utilities increased after the War; electric utility companies came to rely on bonds more than stocks, especially foreign bonds by using British and American investment bankers as underwriters. The access to foreign capital was quite important in order to meet huge financial demands of Japanese electric utilities.

In the manufacturing industry, the patterns of corporate finance of the two nations were quite similar to each other. Before World War I, both relied on equity finance. In the United States, the smaller scale of the manufacturing industry than railroads and public utilities, the exposure to intense competition, and the unstable demand for manufacturing products, all led manufacturing companies to the use of stocks. The Japanese cotton industry also used stocks not bonds. It could not obtain credit from investors large enough to issue bonds in part because the Bank of Japan did not discount the bonds of the cotton spinning industry.

After World War I, internal funds became more important both in the U.S manufacturing industry and in the Japanese cotton industry. In the 1920s of the United States, the size of the manufacturing companies grew through mergers and acquisitions. The large-scale companies made huge profits and accumulated earnings, which made internal finance possible. Similarly in Japan, the cotton spinning industry organized an oligopolistic system through consolidation and accumulated internal funds. 
The adoption of the holding company form was also a common feature in corporate finance in the two nations; although zaibatsu, a holding company form in Japan, was often regarded as unique Japanese features, many U. S. firms, especially, public utilities companies also used the holding company form. Holding companies in both nations functioned similarly in terms of finance. The holding companies obtained dividends and interests through the securities holding of subsidiary companies and redistributed these funds to them. Major differences in the use of holding company form between the two nations lay in the managerial roles. In the United States, the holding company form was adopted in order to obtain control in the industry as wide as possible with limited capital. The U. S. businessmen achieved their goal by creating multiple layers of holding companies. On the other hand, in Japan, the maintenance of family enterprise was the one of the most important purpose for zaibatsu. In order to sustain close ties between zaibatsu headquarters (holding companies) and their direct subsidiaries, the structure of holding company form was rather flat in Japan.

Thus, although the distinctive features of corporate finance in each nation existed, there were also the similarities. Scholarship has often focused on national differences in corporate finance, but previously identified national patterns seems to be less significant than emphasized, considering the many common features between the two nations.

This study also shows that the national patterns in the two nations obscure the complexity of corporate financial practices. In fact, the reactions of companies in both countries to evolving financial institutions were quite varied, and the financial practices of major industries from 1880 to 1930 were diverse in the United States and Japan. In the United States before World War I, the railroad industry relied on bond issues, which were 
underwritten by investment bankers, with strong international connections. Railroad stocks were in general not widely held by the public. After the war, railroad companies came to use internal funds. In public utilities, most of the firms relied on bond issues through time, although stocks of public utilities, especially the telephone industry, were more widely distributed than those of railroad companies due to their large service $r$ area. Even after World War I, they did not use internal funds in part because of the immaturity of the utility industries. In manufacturing, before World War I, firms usually relied on equity finance in part due to the smaller size of firms in manufacturing than the railroads and public utilities and in part due to its instability of business. After World War I, however, many of the firms came to rely on internal funds more than stocks.

Meanwhile, in Japan, the railroad industry heavily relied on equity finance before its nationalization of 1906. Its stocks were widely held in the public. The role of banks was indirect; they just made stock collateral loans to investors. In electric utilities, firms used mainly stocks, which were widely distributed after the Russo-Japanese War of 1908. After World War I, electric utilities also used bonds. Especially their use of foreign bonds was noteworthy. Meanwhile, the cotton spinning industry used stocks to meet the demand for long-term funds, while relying on bank loans and then credit from trading companies for short-term funds before the Russo-Japanese War. After the war, the use of internal funds increased to meet the demand both for long- and short-term financial needs. In particular after World War I, when the industry formed an oligopolistic structure, it heavily relied on internal funds.

These generalizations about corporate financial practices are further complicated, when we focus on individual companies. Unlike other railroad companies in the West, 
one of the major railroad companies in the East, Pennsylvania Railroad, heavily relied on equity finance before World War I; the company attempted to avoid increasing fixed charges borne from bond issues. The high standing of the company enabled it to use common stock as a major financial source to meet its huge financial needs. Similarly, A.T. \& T. used mainly stock issues. The company was not able to issue bonds in its early years because the assets of the telephone industry were not suitable for collaterals. The newly emerged telephone industry was also so risky that the company could not sell bonds. Even after World War I when the telephone business prospered, the company continued to rely on stock due to its corporate policy, emphasizing the importance of selffinance. United States Steel also used huge amounts of stock to finance its promotion, but unlike other industrial companies, its expansion relied on bonds before World War I and internal funds after the War.

In Japan, on the other hand, the Nihon Railway and the Tokyo Electric Light before 1920 both relied on equity finance, but their shares were more closely held than those of other companies in the same industry. High dividends on their stock and premiums of new issues, which were allocated to existing shareholders, prevented shareholders from reselling shares. Finally, the Kanebuchi Spinning had close ties with the Mitsui Bank, while other spinning firms were independent from banks.

Holding company finance demonstrated another aspect of corporate financial practice in both nations. In the United States, of the three companies dealt with in the second chapter, one was a pure holding company (the United States Steel) and the other two were parent companies (The Pennsylvania and A.T.\&T). While pure holding companies do not deal with management of businesses, parent companies do. Aiming to 
achieve monopolistic power and managerial efficiency, these companies used the holding company form. As Berle and Means explain, the stock of the pinnacle company was widely held by the public and the managers obtained control through the dispersed power of stockowners. Similarly, many other holding companies distributed their stocks widely through the securities market, but unlike these three companies, they often used devices such as pyramiding, voting rights, and voting trusts, to obtain centralized power over the constituent companies with limited amounts of capital.

In Japan, zaibatsu often financially supported the three major industries considered in Chapter 3, but the purpose was not to obtain control. Due to huge financial needs of the three industries, zaibatsu were not able to accumulate funds enough to control the companies in those industries. For example, although the Mitsubishi group owned shares of the Nihon Railway, its ownership was too small to influence the management of the company. The Tokyo Electric Light also had close tie with the Mitsui group, but the Mitsui group did not own shares of the company. These two companies were not included in zaibatsu groups. In addition, although the Kanebuchi Spinning at first belonged to the Mitsui group, the Mitsui group pulled away from the company as the company accumulated capital for itself. In contrast, the holding companies in zaibatsu were formed from managerial consideration. Interestingly, banks within zaibatsu was not actively involved in financing group companies unlike main banks in the post- World War II period.

Thus, corporate financial practices were influenced not only by financial institutions, the size of the company, and the timing of industrialization, but also many other factors such as political and economic changes, production process, the level of 
risk, the degree of maturity in the industry, government intervention, and even managers' preference and ownership consideration.

The transformation of corporate financial practices across time in both nations also shows that the national patterns were plastic. In the United States before World War I, U.S firms relied on investment bankers. Although they were not important shareholders of the firms, their financial role and control power resembled the activity of main banks in the post-World War II Japan. On the other hand, the reliance on equity finance of Japanese railroads, electric utilities, and cotton spinning before World War I seems to fit the American model of corporate finance. In addition, in post-World War I Japan, banks' role as underwriters of electric utility bonds was quite similar to that of investment bankers in the United States before World War I. Corporate financial practices changed across time, and neither converged into one system nor remained divergent. According to the notion of path dependency, corporate financial practices seem static; history and culture determined financial institutions and then financial practices of the companies. However, corporate financial practices were much more dynamic.

Our thesis reveals that corporate financial practices are too complex to be presented simply by the stereotyped national patterns. So are capitalist systems from a broader perspective. Many scholars are now insisting that capitalist systems are different from nation to nation, attributing the persistence of national patterns of capitalist systems to a notion of path dependency. This seems true when we look at the capitalist systems in post-World War II United States and Japan. The capitalist system in the United States was based on competition and anti-monopoly policy, and the one in Japan reflected group-oriented culture and active government. However, capitalist system in any nation 
was not unitary and unchanging. As this study shows the reaction of firms to financial institutions and opportunities were diverse and did not always conform to economic policy and culture. 


\section{ENDNOTES}

[1] Alfred D Chandler,. Jr., Scale and Scope: The Dynamics of Industrial Capitalism, Harvard University Press, (Cambridge: Mass., 1990).

[2] Peter A. Hall, "The Political Economy of Europe in an Era of Independence", in Continuity and Change in Contemporary Capitalism, ed. Herbert Kishelt, Peter Lange, Gary Marks, and John Stephens, 135-163 (Cambridge: Cambridge University Press, 1999).

[3] J. Rogers Hollingsworth and Robert Boyer, "Coordination of Economic Actors and Social System of Production: The Embeddedness of institutions", in Contemporary Capitalism: The Embeddedness of Institutions, ed. J. Rogers Hollingsworth and Robert Boyer, 1-18, (Cambridge: Mass., Cambridge University Press, 1977).

[4] Hollingsworth, "Continuities and Change in Social System of Production: The Case of Japan, Germany, and the United States", in Contemporary Capitalism: The Embeddedness of Institutions, ed. J. Rogers Hollingsworth and Robert Boyer, 265-310, (Cambridge: Mass., Cambridge University Press,1977); Hall, 1999 ; and Herbert Kishelt, Peter Lange, Gary Marks, and John Stephens, "Convergence and Divergence in Advanced Capitalist Democracies", in Continuity and Change in Contemporary Capitalism, ed. Herbert Kishelt, Peter Lange, Gary Marks, and John Stephens, 427-460 (Cambridge: Cambridge University Press, 1999).

[5] Adolf A. Berle and Gardiner C. Means, The Modern Corporation and Private Property, (New York: The MacMillan Company): 82.

[6] Berle and Means, 107-111.

[7] Alexander Gerschenkron, Economic Backwardness in Historical Perspective, (Cambridge: Mass.,Harvard University Press, 1962): 14.

[8] Gerschenkron, 14.

[9] Gerschenkron, 19-20.

[10] ibid.

[11] Randall K. Morck and Lloyd Steier, "The Global History of Corporate Governance: An Introduction" in A History of Corporate Governance around the World, ed. Morck (Chicago: The University of Chicago Press, 2005).

[12] Alfred D. Chandler, Jr., The Visible Hand: The Managerial Revolution in American Business, (Cambridge: Mass., Harvard University Press, 1977). 
[13] Wendy Carlin and Colin Mayer, "How Do Financial Systems Affect Economic Performance?" in Corporate Governance: Theoretical and Empirical Perspectives, ed. Xavier Vives, (Cambridge: Mass., Cambridge University Press, 2000): 137-166.

[14] Mark J. Roe, Strong Managers, Weak Owners: The Political Roots of American Corporate Finance, (Princeton, Princeton University Press, 1994); "Political

Precondition to Separating Ownership from Corporate Control", Stanford Law Review, 53. (Dec. 2000): 539-606.

[15] Rafael Laporta, Franco Lopez-de Silanes, Andrei Schleifer, and Robert Vishny, "Corporate Ownerhship Around the World", in the Journal of Finance, LIV, no.2, (April, 1999): 471-517.

[16] John Zysman, Governments, Markets, and Growth: Financial Systems and the Politics of Industrial Change, (Itacha: Cornell University Press, 1983).

[17] For example, DAcid L. Hall explains that the fishery industry in Hokkaido, Japan developed as a process of "proto-industrialization", in other words, "rural manufacturing for long-term trade" in the nineteenth century and concludes that the evolution of capitalism was influenced by earlier conditions. (Howell, Capitalism from Within, (Berkeley: University of California Press, 1995): xi).

[18] www.e.u-tokyo.ac.jp/ takeda/gyoseki/keizaishi 1. htm. (accessed May 20, 2008).

[19] Richard Sylla and George David Smith, "The Transformation of Financial Capitalism: An Essay on the History of American Capital Markets", in Financial Markets, Institutions \& Instruments, 2, no.2, (May 1993):1.

[20] Philip Scranton, Endless Novelty: Specialty Production and American Industrialization 1865-1925, (Princeton: Princeton University Press, 1997).

[21] William W. Lockwood, The Economic Development of Japan: Growth and Structural Change, (Princeton, Princeton University Press, 1968):193.

[22] Robert Cull, Lance E. Davis, Naomi R. Lamoreaux, and Jean-Laurent Rosenthal, "Historical Financing of Small and Medium-Sized Enterprises", Working Paper 11895, National Bureau of Economic Research, (Cambridge: Mass., October 2005).

[23] Michael, C. Jensen, "Eclipse of the Public Corporation", Harvard Business Review, (September-October 1989 revised in 1997). http://papers.ssrn.com/absrtruct+14619 (accessed March 2007).

[24] Hollingthworth, 1997, 265-310. 
[25] Jung-Koo Kang and Rene M. Stulz, "Is Bank-Centered Corporate Governance Worth It? A Cross-Performance of Japanese Firms during the Assets Price Deflation", National Bureau of Economic Research Working Paper Series, no. 6238, (Cambridge: Mass., 1996); Randall Morck, Masao Nakamura, and Anil Shivdasani, "Banks, Ownership Structure, and Firm Value in Japan", Journal of Business, 73, (October 2000): 539-69; David E. Weinsteinand and Yishay Yafeh, "On the Cost of a Bank-Centered Financial System: Evidence from Changing Main Banking Relation in Japan “, The Journal of Finance, 53, no. 2 (April, 1998): 635-672.

[26] Takeo Hoshi, Anil Kashyap, and David Scharfstein, "Bank Monitoring and Investment: Evidence from the Changing Structure of Japanese Corporate Banking Relationship", National Bureau of Economic Research Working Paper Series, no. 3079, (Cambridge, 1989); Hideki Miyajima, "The impact of Deregulation on Corporate Governance and Finance", Is Japan Really Changing Its Way?: Regulatory Reform and the Japanese Economy, ed. Lonny E. Carlie and Mark C. Tilton, 33-75 (Washington D.C., Brookings Institution Press, 1998).

[27] Caroline Fohlin, "Does Civil Law Tradition and Universal Banking Crowd Out Securities Markets? Pre-World War I Germany as Counter-Example", Enterprise \& Society, (September 3, 2008): 635.

[28] Berle and Means.

[29] Richard Sylla and Smith George D., "Capital Markets", in Encyclopedia of the United States in the Twentieth Century, 1209-1241(New York: Charles Scribner's Sons, 1996); Smith, George D. and Richard Sylla, "The Transformation of Financial Capitalism: An Essay on the History of American Capital Markets", Financial Markets, Institutions \& Instruments, 2, no.2, (May 1993): 1-62.

[30] According to Chandler, New England's abundant capital allowed railroad companies to raise funds through the sales of stock to such local investors as "farmers, merchants, and manufacturers living along the line of road." (Chandler, The Visible Hand, 91) Meanwhile, Cleveland and Powell insist that in the Mid-West and South, where local capital was insufficient, railroad companies exchanged shares for land, labor and materials. (Frederick A Cleveland and Fred Wilber Powell, Railroad Promotion and Capitalization in the United States, (New York: Longmans, Green, and Co., 1909): 52).

[31] Chandler, The Visible Hand, 91.

[32] Chandler, The Visible Hand, 92.

[33] Mira Wilkins, The History of Foreign Investment in the United States to 1914, (Cambridge: Mass., Harvard University Press, 1989): 78-79.

[34] Carosso, The Morgans, 55. 
[35] Carosso, The Morgans, 115.

[36] Chandler, The Visible Hand, 134.

[37] Chandler, The Visible Hand, 155.

[38] The amount is calculated by using the GDP deflator.

[39] Chandler, The Visible Hand, 155.

[40] Ronald C. Michie, The London and New York Stock Exchange, 1850-1914, (Boston: Allen \& Unwin, 1987): 170.

[41] Frederick A. Cleveland, and Fred Wilber Powell, Railroad Finance, (New York: D. Appleton and Company, 1912): 278.

[42] Commercial and Financial Chronicle, 67 Decemver.22, 1888: 762.

[43] New York Times, March 23,1893:3.

[44] Chandler, The Visible Hand,174.

[45] Augustus J. Veenendaal, Jr., Slow Train to Paradise: How Dutch Investment Helped Build American Railroad, (Stanford: Stanford University Press, 1996):50.

[46] George Heberton Evans, "The Early History of Preferred Stock in the United States," The American Economic Review, 10, no.1 (March, 1929): 43-58.

[47] Arthur S. Dewing, The Financial Policy of Corporations, IV, (New York, The Ronald Press 1920):124.

[48] Veenendaal, 51.

[49] Dewing, The Financial Policy of Corporations I, (New York, The Ronald Press 1919): 77.

[50] Dewing, The Financial Policy of Corporations I, 50.

[51] Dewing, The Financial Policy of Corporation IV, 88.

[52] Veenendaal, 52.

[53] Dewing, The Financial Policy of Corporations I, 89.

[54] Wilkins, The History of Foreign Investment in the United States to 1914, 193-198. 
[55] Dewing, The Financial Policy of Corporations II, (New York, The Ronald Press 1919): 27.

[56] J. Bradford De Long, "Did J.P Morgan's Men Add Value?: A Historical Perspective on Financial Capitalism", Working Paper no. 3426, National Bureau of Economic Research, Inc, (1990).

[57] Frank Haigh Dixon, "The Economic Significance of Interlocking Directorates in Railway Finance," The Journal of Political Economy, 22, no. 10 (December, 1914): 937954.

[58] Richard Sylla and George David Smith., "Capital Markets", in Encyclopedia of the United States in the Twentieth Century, (New York: Charles Scribner's Sons, 1996): 1214-1217.

[59] Dewing , Corporate Promotion and Reorganization, (Cambridge: Mass., Harvard University Press, 1914): 6; Arthur S. Dewing, The Financial Policy of Corporations V, (New York, The Ronald Press, 1920): 68-69.

[60] Dewing, The Financial Policy of Corporations, V, 68-69.

[61] Dewing. The Financial Policy of Corporations, V, 87-88.

[62] Dewing, The Financial Policy of Corporations, V, 103.

[63] Chandler, The Visible Hand, 184.

[64] Dewing, The Financial Policy of Corporations, V, 125.

[65] Edward G Campbell, Reorganization of the American Railroad system, 1893-1900, (New York: Columbia University Press, 1938): 320.

[66] John Moody, The Masters of Capital: A Chronicle of Wall Street, (New Haven: Yale University Press, 1919): 28-9.

[67] Ron Chernow, The House of Morgan: An American Banking Dynasty and the Rise of Modern Finance, (New York: Atlantic Monthly Press, 1990): 67.

[68] The Northern Securities Company was built to hold the stock of Great Northern and the Northern Pacific. The stocks of these companies were owned by two rival railroad businessmen, James J. Hill backed by J.P. Morgan and Edward C. Harriman backed by Kuhn, Loeb, (Chandler, The Visible Hand, 173-174).

[69] Campbell, 320-22. 
[70] Albro Martin, Enterprise Denied: Origins of the Decline of American Railroad, 1897-1917, (New York: Columbia University, 1971).

[71] Dewing, The Financial Policy of Corporations: Expansion, IV, 83-91.

[72] Vincent P Carosso, Investment Banking in America, (Cambridge, Mass.: Harvard University Press, 1970):126.

[73] Richard Sylla and George David Smith, "The Transformation of Financial Capitalism: An Essay on the History of American Capital Markets", Financial Markets, Institutions \& Instruments, 2, no.2, (May 1993):30.

[74] Smith and Sylla, "The Transformation of Financial Capitalism", 31-32.

[75] Commercial and Financial Chronicle, 106, May 4, 1918: 1901, May.11,1918: 2011, May 18, 1918:2123, May 25, 1918: 2229, January 8, 1918: 2410, and June 29,1918: 2755; Commercial and Financial Chronicle, 107, Jul.13, 1918:180; Commercial and Financial Chronicle,108, Jan. 25,1919:377 -109, Feb.1, 1919:478, and Mar.9,1919: 973.

[76] Martin, 352.

[77] William Leonard, Railroad Consolidation under the Transportation Act of 1920, (New York: AMS Press, 1968): 9.

[78] Martin, 10.

[79] This amount is the sum of $\$ 124$ million of depreciation to operating expenses, $\$ 3.2$ billion of equipment depreciation, $\$ 9.5$ million of depreciation reserves for nonoperating physical properties, and $\$ 308$ million of retirement. (Hearings before the Temporary National Economic Committee, Congress of the United States Seventy-Six Congress First Session, Investigation of Concentration of Economic Power, Part 9: 3565).

[80] Hearings before the TNEC $76^{\text {th }}$ Congress: 3564-3569.

[81] Earl Adolphus Saliers, Principle of Depreciation, (New York: The Ronald Press Co., 1916): 81.

[82] Floyd W. Mundy, The Value of a Railroad Security, (Boston: American Institute of Finance, 1922): 17.

[83] Berle and Means, 34.

[84] Jules I. Bogen, Analysis of Railroad Securities : A Guide to the Determination of Investment Values, (New York, the Ronald Press, 1928): 40-67.

[85] Commercial and Financial Chronicle, 105-1, December 22, 1917: 2454. 
[86] Leonard, 58.

[87] Leonard, 58.

[88] James C. Bonbright, and Gardiner Means, The Holding Company: Its Public

Significance and Its Regulation, (New York: McGraw-Hill Book Company, 1932):266.

[89] Bonbright and Means, 235-262.

[90] Chernow, 258.

[91] Vincent P. Carosso, Investment Banking in America, (Cambridge, Mass.: Harvard University Press, 1970): 284.

[92] George H. Burgess, and Miles C. Kennedy, Centennial History of the Pennsylvania Railroad Company, 1846 to 1946, (Philadelphia: Arno Press, 1979): 35-36.

[93] Moody's Analyses of Railroad Investment, 1917: 541.

[94] Under the tight money market during the years, the company chose to issue shortterm notes rather than long-term debt in order to reduce the financial burden due to high interest rates; Annual Reports, the Pennsylvania Railroad Company, 1880-1914.

[95] Scrip dividend is the dividends paid in the form of notes. Buying this, a company could defer the actual distribution of the assets. (Dewing, The Financial Policy of Corporations, III, 99).

[96] Annual Reports, 1891-1914.

[97] Moody's Analyses of Railroad Investment, 1917: 546.

[98] Dewing, The Financial Policy of Corporations, 1, 50.

[99] Annual Reports, The Pennsylvania Railroad, 1893, 1895, 1908.

[100] Annual Report, The Pennsylvania Railroad, 1883:15.

[101] Annual Report, The Pennsylvania Railroad, 1884: 38.

[102] Moody's Analyses of Railroad Investment, 1912: 414.

[103] Annual Reports, The Pennsylvania Railroad, 1902, 1905.

[104] Wilkins, The History of Foreign Investment in the United States to 1914, 81.

[105] ibid, 195, 217. 
[106] For example, in the issue of convertible bonds in 1905, 60 per cent of the syndicate holdings were sold, and the rest was distributed among the participants of the syndicate. (Commercial and Financial Chronicle, 82, April.7, 1905:805).

[107] The total amount of internal funds is the sum of surplus, reserves, and accumulated depreciation.

[108] Commercial and Financial Chronicle, 106, March 9, 1918: 1031-1032.

[109] Commercial and Financial Chronicle, 112, June.18, 1921:2643.

[110] Leonard, 1968.

[111] The Pennsylvania Railroad made an offering to its shareholders of new stock in amount of $\$ 79.9$ million during the stock market boom. Even after the crash of the stock market, it made another allotment of $12 \frac{1}{2}$ per cent of shareholders' holdings and invited employees of the company to subscribe \$18 million; Burgess and Kennedy, 67.

[112] Burgess and Kennedy, 582.

[113] Commercial and Financial Chronicle, 98, January 31, 1914: 388.

[114] Mira Wilkins, The History of Foreign Investment in the United States, 1914-1945, (Cambridge: Mass, Harvard University Press, 2004): 82.

[115] Annual Reports, The Pennsylvania Railroad Company, 1914, 1930.

[116] Berle and Means, 55; Annual Reports, the Pennsylvania Railroad, 1902-1930.

[117] Carosso, The Morgans, 268.

[118] Francis Former's Address, in Public Utility Finance, ed.Walter Lagerquist, (Chicago and New York: A.W. Shaw Company, 1927): 54.

[119] Lagerquist, 4.

[120] Lagerquist, 14.

[121] Chernow, 67.

[122] Eli Winston Clemens, Economics and Public Utilities, (New York: AppletonCentury-Crofts, Inc., 1950): 101.

[123] Albert S. Keister, "Recent Tendency in Corporate Finance", The Journal of Political Economy, 30, no.2, (April.1922): 257-273. 
[124] Clemens, 102; Since open issue reduced the security of bonds, the railroad companies were required to make a certain level of profits for subsequent issue of bonds. According to Dewing argues, the earning of public utilities, in general, should be "from 1.5 to 3 times the bond interest."'( Dewing, The Financial Policy of Corporation.1, 25).

[125] Lagerquist, 77.

[126] Dewing, The Financial Policy of Corporations, I, 56.

[127] Lagerquist, 77.

[128] According to Lagerquist (1927, 160), in electric light companies, common stock 50 per cent, preferred stock 10 per cent, and funded debt 40\%, in gas companies, 30 per cent, 5 per cent, and 65 per cent respectively.

[129] Dewing, The Financial Policy of Corporations, II, 76.

[130] Carosso, The Morgans, 271.

[131] Carosso, The Morgans, 270-273.

[132] Carosso, The Morgans, 493.

[133] Clemens, 69.

[134] The U.S. Fuel Administration restricted show window and interior display lighting and issued the Daylight Saving Act to reduce the use of gas and electricity.(Commercial and Financial Chronicle, 106-1, Jan, 26, 1918:392;106-2, April 6,1918:1464).

[135] Lagerquist, 71.

[136] Clemens, 103-111, 118-119.

[137] Clemens, 491.

[138] Ebasco Service Incorporated, Electric Utility Financing, (New York,1948):22.

[139] Clemens, 108-109.

[140] Ralph E. Heilman, "Customer Ownership of Public Utilities”, in Walter W. Lagerquist, Public Utility Finace, (Chicago and New York: A.W. Shaw Company, 1927): 287-288.

[141] Heilman, 292.

[142] Heilman, 292-294; Clemens, 109-110. 
[143] Warren Stehman, The Financial History of the American Telephone and Telegraph Company, (New York: Augustus M. Kelley Publishers, 1967): 8-33.

[144] Annual Report, The American Telephone \& Telegraph Company, March 1910:18.

[145] For example, in July 1913, the U.S. Government filed a suit against the company due to the violation of the Anti-Trust Law in a number of western states.(Commercial and Financial Chronicle, 97, July 26, 1913:239) Also, in July 1917, the Cook County Supreme Court in Illinois decreed that the Bell System is a monopoly and ordered the company to operate separate organization in Illinois, Indiana and Ohio. (Commercial and Financial Chronicle, 105-1, July 14,1917: 1803).

[146] Robert W. Garnet, The Telephone Enterprise: The Evolution of the Bell System's Horizontal Structure, 1876-1909, (Baltimore: John Hopkins University Press, 1985): 77.

[147] Garnet, 77; Stehman, 291.

[148] Stehman, 166.

[149] Stehman, 69.

[150] Stehman, 108.

[151] Annual Report, The American Telephone \& Telegraph Company,1899-1911.

[152] Commercial and Financial Chronicle, 87, December 5, 1908: 1481.

[153] Commercial and Financial Chronicle, 88, January 30,1909:296: Annual Report, The American Telephone \& Telegraph Company, 1910-1915.

[154] Commercial and Financial Chronicle, 88 January 8,1909: 1411; Feb 13,1909:453.

[155] Berle and Means, 55; Annual Reports, The American Telephone \& Telegraph Company ,1901,1914.

[156] Horace Coon, American Tel. and Tel.: The Story of A Great Monopoly, (Freeport: New York, Books for Libraries Press, 1939): 9.

[157] Coon, 9.

[158] Annual Reports, The American Telephone \& Telegraph Company, 1900-1908.

[159] Garnet, 116.

[160] New York Times, November 5,1905: 1. 
[161] New York Times, December 11,1905: 5.

[162] Annual Reports, The American Telephone \& Telegraph Company, 1900-1914.

[163] Annual Report, The American Telephone \& Telegraph Company; Commercial and Financial Chronicle, 74. 1902, April 5: 726.

[164] Commercial and Financial Chronicle, 80, March 17,1905: 12.

[165] Garnet, 117.

[166] Wilkins, The History of Foreign Investment in the United States to 1914.

[167] Coon, 4; Garnet, 127.

[168] Annual Reports, The American Telephone \& Telegraph Company.

[169] The amount of retained earnings is the sum of surplus and reserves. But depreciation is included in reserves in balance sheet of the A.T. \& T.

[170] Peter Temin, The Fall of the Bell System: A Study in Prices and Politics, (Cambridge, Mass,: Cambridge University Press, 1987): 11.

[171] Annual Report, The American Telephone \& Telegraph Company, 1918.

[172] Commercial and Financial Chronicle, 108-1, November 11, 1919: 81.

[173] Annual Reports, The American Telephone \& Telegraph Company.

[174] Annual Reports, The American Telephone \& Telegraph Company.

[175] Commercial and Financial Chronicle,110, March 6,1920: 979.

[176] Temin, 11.

[177] ibid.

[178] Annual Report, The American Telephone \& Telegraph Company, 1922: 6.

[179] Annual Reports, The American Telephone \& Telegraph Company.

[180] Annual Report, The American Telephone \& Telegraph Company, 1928: 7.

[181] Annual Report, The American Telephone \& Telegraph Company, 1922:15.

[182] Hailman, 285. 
[183] Annual Report, The American Telephone \& Telegraph Company, 1922 : 15.

[184] Wilkins, The History of Foreign Investment in the United States, 1914-1945, 53, 205.

[185] Annual Report, The American Telephone \& Telegraph Company, 1921: 11.

[186] Annual Report, The American Telephone \& Telegraph Company, 1924: 12.

[187] Annual Reports, The American Telephone \& Telegraph Company, 1914- 1929.

[188] Chandler, The Visible Hand.

[189] Naomi R. Lamoreaux, The Great Merger Movement in the American Business 1895-1904, (Cambridge, Mass.; Cambridge University Press, 1985).

[190] For example, gross assets of General Motors amount to $\$ 53$ million, those of $\mathrm{Du}$ Pont $\$ 83.4$ million, and those of General Electric \$138.4 million in 1914 . On the other hand, gross assets of the Pennsylvania Railroad amounted to $\$ 951.4$ million, those of the New York Central Railroad Company \$834 million, those of the Baltimore \& Ohio \$694 million, and those of AT\&T as $\$ 628.8$ million. In 1930, gross assets of the three industrial firms were $\$ 473.8$ million, $\$ 620.5$ million, and $\$ 493$ million respectively. Meanwhile, gross assets of major public utility companies such as Consolidated Gas Company of New York and Cities Service Corporation was more than \$1200 million respectively (Annual Reports).

[191] William Hausman, Peter Hertner, and Mira Wilkins, Global electrification: Multinational Enterprise and International Finance in the History of Light and Power, 1878-2007, (Cambridge: Mass., Cambridge University Press, 2008): 22.

[192] Dewing, Financial Policy of Corporations, V, 62; Lagerquist, 4-5.

[193] Dewing, Corporate Promotion and Reorganization, (Cambridge, Mass.; Harvard University Press, 1914): 7.

[194] Dewing, Financial Policy of Corporations, II, 57; III, 121-122.

[195] Meade, Edward Sherwood, Trust Finance: A Study of Genesis, Organization, and Management of Industrial Combinations, (New York: D. Appleton and Company, 1905): 274.

[196] Dewing, Financial Policy of Corporations, I, 56.

[197] Dewing, Financial Policy of Corporations, I, 56.

[198] Carosso, The Morgans, 41. 
[199] Meade, 254.

[200] Albert Ralph Koch, The Financing of Large Corporations, 1920-1929, (New York: National Bureau of Economic Research, 1943): 38.

[201] John Litner, "The Financing of Corporations", in The Corporation in Modern Society, ed. Edward S. Mason, (Cambridge: Mass., Harvard University Press, 1961): 180.

[202] Dewing, The Financial Policy of Corporations, V, 197-198.

[203] Koch, 106-107.

[204] Abraham Berglund, The United States Steel Corporation: A Study of the Growth and Influence of Combination in the Iron and Steel Industry, (New York: the Columbia University Press, 1907): 63-67.

[205] Commercial and Financial Chronicle, 72, January 15,1901: 441.

[206] John Moody, Truth about the Trust: A Description and Analysis of the American Trust Movement, (New York: Moody Publishing Company, 1904): 165.

[207] Berglund, 78.

[208] Berglund, 76.

[209] Annual Report, The United States Steel Corporation, 1912: 30.

[210] Commercial and Financial Chronicle, 100, June 5, 1915: 1860.

[211] Commercial and Financial Chronicle, 110, March 6, 1920: 925-926.

[212] Meade, 194-196.

[213] Commercial and Financial Chronicle, 90, April 23, 1910: 1106.

[214] Wilkins, The History of Foreign Investment in the United States to 1914, 475, 603.

[215] Moody's Manual of Investment, 1920: 1232.

[216] Since accumulated depreciation was charged off from depreciation reserve, the amount of the depreciation was added back to gross assets and surplus to calculate the ratio.

[217] Commercial and Financial Chronicle, 90, March 19,1910: 741.

[218] Commercial and Financial Chronicle, 90, March 19,1910: 741-743. 
[219] Carosso, The Morgans, 469-489.

[220] Carosso, The Morgans, 466-489.

[221] Commercial and Financial Chronicle, 102, March 18,1916: 1015.

[222] Annual Reports, The United States Steel Corporation.

[223] Commercial and Financial Chronicle, 110, January 17, 1920: 270.

[224] Annual Reports, The United States Steel Corporation.

[225] The ratio of internal funds to gross assets and that of stocks were not compatible because depreciation charged off was added to gross assets in the former ratio; Annual Report, The United States Steel Corporation.

[226] Hearings from the Temporary National Economic Committee, the Sevnty-Sixth Congress, Testimony of Edward R. Stettinius Jr., Chairman of the Board of the United States Steel Corporation, New York: 3584.

[227] Annual Report, The United States Steel Corporation, 1926-1930.

[228] Commercial and Financial Chronicle, 110-2, April 24,1920: 1710.

[229] Jeffery R. Bernstein, "Japanese Capitalism" in Creating Modern Financial Capitalism: How Entrepreneurs, Companies, and Countries Triumphed in Three Industrial Revolutions, ed.Thomas McCraw (Cambridge, Mass.: Harvard University Press, 1997): 450.

[230] The Tokugawa Period is a time period that the Shogunate ruled Japan from 1603 to 1867. The Meiji Period was a time period that the Meiji Government ruled Japan from 1868 to 1912.

[231] Takeo Kurusu explains that the ryogaesho(merchant banker) was a predecessor of modern bankers during the Tokugawa Period. (Takeo Kurusu, History of the Japanese Financial System [Nihon Kin'yu Seido Hattatsu no Kenkyu\}, Tokyo, Keimeisha, 1930): 4; The reform movement in the 1860s that transformed feudalist system to a centralized system was led by the emperor.

[232] Gary M. Walton and Hugh Rockoff, History of the American Economy, (Fort Worth, The Dayden Oress, 1998): 423.

[233] ibid.

[234] Toyo Keizai Shimpo sha, Kin'yu rokujunen shi, (Tokyo: Toyo Keizai Shinpo sha, 1924): 94 
[235] The Meiji government was obliged to pay a stipend to the nobility and warrior classes to compensate for the abolishment of the base salary given to each noble or warrior family under the Tokugawa regime. To pay off the obligation, the government issued the kinroku kosai in 1876.

[236] Jun'nosuke Nomura, Nihon Kin'yu Shihon Hattatsu shi, (Tokyo, kyoseikakuhan, 1931): 33-51; Toyo Keizai Shinpo Sha, 94-103.

[237] Nomura, 45-47.

[238] Toyo Keizai Shinpo sha, 142.

[239] Toyo Keizai Shinpo sha, 142.

[240] The Banque Nationale de Belgique was established in 1850 as a central bank to centralize the issuing of banknotes," to "help to provide the economy with short-term credits, " and to "act as the government's casher"(Helma Houtman-Smedt, "The Banking System in Belgium through the Centuries", in Handbook on the History of European Banks, ed. Manfred Poul, Brookfield, Vt., 1994: 64). It is different from the Banque de Belgique, founded in 1835, which evolved into a commercial bank after 1838. (HoutmanSmedt, 50).

[241] Toyo Keizai Shinpo sha, 115-132.

[242] Mitsui Archives, Mitsui Jigyo shi, 2, (Tokyo,1980): 382.

[243] Arai, Shinji, Yokohama Shokin Ginko Zenshi, 2, (Tokyo, Toyo Keizai Shinpo sha, 1981).

[244] Toyo Keizai Shinpo sha, 148-153.

[245] Toyo Keizai Shinpo sha, 95-96; Tomoyuki Ishihama, Theory of Financial organization, [Tokushu Kin'yu Kikanshi ron], (Tokyo, Iwanami Shoten 1992): 109-115.

[246] Toyo Keizai Shinpo sha, 228-248; Ishihama, 100-103.

[247] Noda, Masaho, Nihon Shoken Shijo Seiristushi, (Tokyo: Yuhikaku, 1980): 4.

[248] Tokyo Kabushiki Torihikijo, Toyko Kabushiki Torihikijo Gojunenshi, (Tokyo: Tokyo Kabushiki Torihikijo, 1928): 111-245.

[249] Until the passage of the Commercial Code in 1890, the issue of bearer stock was prohibited; Takeo Hoshi and Anil Kashyap, Corporate Finance and Governance in Japan: The Road to the Future, (Cambridge: Mass.,The MIT Press, 2001). 
[250] Mark Mason, American Multinationals and Japan: The Political Economy of Japanese Capital Controls, 1899-1980, (Cambridge, Mass., Harvard University Press, 1992): 22-47.

[251] Mason, 22-47; Masaru, Udagawa, "Business Management and Foreign-Affiliated Companies in Japan before World War II", in Foreign Business in Japan Before world War II, ed. Takeshi Yuzawa and Masaru Udagawa, (Tokyo: University of Tokyo Press, 1990): 6.

[252] Noda, 173-181.

[253] Tomomi Iwakura was a politician as well as a court noble from the late Tokugawa period to the early Meiji Period. He organized the Iwakura Mission, 1871-1873, to inspect European institutions and culture; Tomomi Iwakura, , "Letter to Tokumei Zenken Daihukushi” Nov.3, 1972, in Iwakura-ko Jikki, 1968: 1014.

[254] Noda, 48.

[255] Yoshiro Miwa and J. Mark Ramseyer, "Banks and Economic Growth: Implications from Japanese History", Journal of Law and Economics, (April 2002): 143.

[256] Miwa and Ramseyer, 144.

[257] Iwakura, 1014.

[258] Noda, 61-2.

[259] Noda, 51.

[260] According to the Ministry of Agriculture, Forestry and Fisheries, rice consumption person in 1874 is $102 \mathrm{~kg}$. http://www.shizuoka.info.maff.go.jp (accessed January 10, 2008).

[261] Noda, Nihon Shoken Shijo Seiritsu sh, 106-7.

[262] Noda, Nihon Shoken Shijo Seiritsu shi, 79.

[263] Noda, Nihon Shoken Shijo Seiritsu shi, 121.

[264] Noda, Nihon Shoken Shijo Seiritsu shi, 69.

[265] Tokyo Kabushiki Torihikijo.

[266] Noda, Nihon Shoken Shijo Seiritsu shi, 146-155.

[267] Noda, Nihon Shoken Shijo Seiritsu shi , 92-96. 
[268] Noda, Nihon Shoken Shijo Seiritsu shi, 81-87.

[269] Noda, Nihon Shoken Shijo Seiritsu shi, 174.

[270] The laws secured the foundation mortgage of railroads and clarified the adjustment process of rights to collateral of multiple bondholders (Noda, 181-183).

[271] Japan Indsutial Bank, Nihon Gaisai Shoshi, (Tokyo:Japan Industrial Bank, 1948): 46-49.

[272] Nationalized railroads often had foreign bondholders.

[273] Noda, Nihon Shoken Shijo Seiritsu shi, 189.

[274] Noda, Nihon Shoken Shijo Seiritsu shi, 139.

[275] Naofumi Nakamura, "The Nihon Railway Gedai” in Eigyo Hokokusho Shusei: iii.

[276] The Nihon Railway was highly protected by the government, compared with other railways. For example, the Kyushu railway received the guarantee of 5\% interest only for their stock, and Sanyo and Hokkaido Colliery Railway did not receive any guarantee of interest but subsidies of $¥ 2,000$ and $¥ 5000$ per mile respectively. According to Noda, the governmental support to the company was explained by its policy. It aimed at the concentration of capital and the protection of the wealth of the nobility who were the major financiers of the company (Noda, 51).

[277] Noda, Nihon Shoken Shijo Seiritsu shi, 50-51.

[278] According to Noda, tight money raised interest rate high in 1882, which discouraged investors to turn to the company's stock with the government guarantee of 8 per cent interest. (Noda, 56).

[279] Eigyo Hokokusho, The Nihon Railway, 1883.

[280] Eigyo Hokokusho, The Nihon Railway, 1882.

[281] Iwakura, II: 791; Eigyo Hokokusho, The Nihon Railway, 1882.

[282] Masaho Noda, Nihon TetsudoKabushiki Kaisha Enkakushi 2, (Tokyo Nihon Hyoronsha, 1980): 5-8.

[283] Eigyo Hokokusho, The Nihon Railway, 1882.

[284] Noda, Nihon Shoken Shijo Seiritsu shi, 50-52.

[285] Noda, Nihon TetsudoKabushiki Kaisha Enkakushi,. 2: 33. 
[286] Noda, Nihon Shoken Shijo Seiritsu shi, 53.

[287] Eigyo Hokokusho, The Nihon Railway Total assets do not include unpaid capital.

[288] Eigyo Hokokusho, The Nihon Railway.

[289] Eigyo Hokokusho, The Nihon Railway.

[290] Eigyo Hokokusho, The Nihon Railway.

[291] Eigyo Hokokusho The Nihon Railway.

[292] Kataoka, Yutaka, Tetsudo Kigyo to Shoken Shijo, (Tokyo: Nihon Keizai Hyoronsha, 2006): 113.

[293] As an individual, Hisaya Iwasaki, the leader of the Mitsubishi group was the biggest shareholder. He owned 2 to 3 per cent of total stock; Nakamura, xi, Table 2.

[294] Nakamura, xiv-xv.

[295] Nakamura, xi.

[296] Eigyo Hokokusho, The Nihon Railway, 1891.

[297] Noda, Nihon Shoken Shijo Seiritsu shi, 88.

[298] Noda, Nihon Shoken Shijo Seiritsu shi, 289.

[299] Ichiro Nakayama, Ichiro Watanabe, Sokuichi Kotake, and Mitsuo Kawada, Centennial History of Electric Utilities, [Denryoku hyakunenshi], (Tokyo: Seikeisha, 1980): 43.

[300] Electric utility industry was dominated by private companies until 1938 when the government established the Nihon Hassoden Co. [Nihon Electricity Generation and Transmission] to control the electric power business under a war regime.

[301] Yoshiro Miwa and J. Mark Ramseyer, "Banks and Economic Growth: Implications from Japanese History", Journal of Law and Economics, (April 2002): 145.

[302] Nakayama, Watanabe, Kotake, and Owada, 89.

[303] Takeo Kikkawa, Nihon Denryoku no Hatten to Masunaga Yasuzaemon, (Nagoya: Nagoya Daigaku Shuppankai,1995): 4.

[304] Kikkawa, 31-32. 
[305] Kikkawa, 22-23.

[306] The company issued debenture bonds bearing 10 years from 1912 (Japan Industrial Bank, Shasai Shoshi, 708).

[307] Kikkawa, 22-23.

[308] Kikkawa, 80.

[309] Kikkawa, 66-75.

[310] Kikkawa, 22-23.

[311] Kikkawa, 58-65.

[312] Harumi Matsushima, "Denryoku Gaisai no Rekishiteki Igi”, Shakai Keizaigaku, 26-6, (1961): 92.

[313] Kikkawa, 126.

[314] Kikkawa, 119.

[315] Matsushima, 101.

[316] Kikkawa, 69.

[317] Kikkawa, 70-71.

[318] Kikkawa, 73.

[319] Kikkawa, 74.

[320] Japan Industrial Bank, Shasai Shoshi, 18.

[321] Mistui Ginko, Mitsui Ginko Hachijunenshi, (Tokyo: Mitsui Ginko, 1957): 221.

[322] Nakayama, Watanabe, Kotake, and Owada, 71-75.

[323] Toyo Kurihara, Denryoku, (Tokyo, Kojyunsha, 1964): 42-44.

[324] Muneo Nitta, , Tokyo Dento Kabushiki Kaisha Kaigyo Gojunenshi, (Tokyo Denryoku Kabushiki Kaisha, 1936 ): Table 5.

[325] In this year, the company faced the difficulties such as the scandal of falsification of accounts, the fire of the Diet Building due to a leakage of electricity, and the loss of a electric station due to a fire, and the economic recession. (Nitta, 49). 
[326] Nitta, Appendix 2.

[327] Nitta, 15.

[328] Kikkawa, 40-41.

[329] Nippon Teikoku Tokei Nenkan, ed. Naikaku Tokei Kyoku.

[330] Kikkawa, 39.

[331] Nitta, 93-4; Japan Indsutirial Bank, Gaisai Shoshi.

[332] Seihin Ikeda, Zaikai Kaiko, (Tokyo, Sekai no Nihon sha, 1949): 218.

[333] Kikkawa, 79.

[334] Zenkoku Kabunushi Yoran, (Tokyo, Diamond Sha,1921).

[335] Mitsui was rather associated with the electrical equipment industry. It had the connection with General Motors and Tokyo Electric (Wilkins, 1974).

[336] Nitta, Appendix, 2.

[337] Nitta, Appendix, 4.

[338] Nitta, Appendix 1; Japan Industrial Bank, Shasai Ichiran, 630-640.

[339] Japan Industrial Bank, Gaisai Shoshi, 77-80.

[340] Kikkawa, 85, 128; The boom of foreign bond issue continued until 1931 when the reimposition of the Gold Embargo led to the severe decline of the foreign exchange market. The company began to redeem the foreign bonds to reduce the amount of interest (Nitta, 206).

[341] Kikkawa, 75-76.

[342] Japan Industrial Bank, Shasai Ichiran, 39-40.

[343] Ikeda, 246-247.

[344] Kikkawa, 75.

[345] Kikkawa, 124.

[346] Ikeda, 220. 
[347] Ikeda, 231.

[348] Noda, 321-2; Kikkawa, 22.

[349] Naosuke Takamura, Nihon Bosekigyo shi, (Tokyo, Hanawa Shobo, 1971): 39-45;

Karl Marx, Capital: A Critique of Political Economy, 1, (Moscow: Foreign Language

Publishing House, 1867): 526.

[350] Kazuo Yamaguchi, Nihon Kin'yushi Kenkyu; Orimono Kin'yu hen, (Tokyo, Tokyo Daigaku Shuppankai, 1974): 3-6.

[351] Takamura, 63-65.

[352] Takamura, 111.

[353] Yamagichi, 3-6.

[354] Hisashi Masaki, Corporate Finance in Japanese Joint-Stock Companies [Nihon no Kabushikikaisha Kin'yu], (Tokyo, Mineruva Shobo, 1973):25; Yamaguchi, 69; and Miwa and Ramseyer, 141.

[355] Yamaguchi, 55.

[356] Yamaguchi, 116-7.

[357] Yamaguchi, 118.

[358] Yamaguchi, 17-21.

[359] According to Wilkins, the Mitsui Trading Company's New York Office handled exports of U.S. raw cotton to Japan since the late nineteenth century. In 1911, the company established a wholly owned subsidiary called Southern Products Company in Houston, Texas, to aid the trading company's raw cotton exports from the United States to Japan. The Mitsui Trading dealt with "more than 30 per cent of the U.S. raw cotton imported into Japan.” (Wilkins, 1989, 516-517).

[360] Wilkins, The History of Foreign Investment in the United States to 1914, 516-517.

[361] Yamaguchi, 35: Takamura, 69-73.

[362] Yamaguchi, 59-65.

[363] Kanebo Kabushikikaisha, History of Kanebo [Kanebo Hyakunenshi], (Tokyo:

Kanebo Kabushikikaisha, 1988): 92, 164.

[364] Kanebo Kabushikikaisha, 164. 
[365] Kanebo Kabuhsikikaisha, 164.

[366] Miwa and Ramseyer, "Corporate Governance in Transitional Economies: Lessons from the Prewar Japanese Cotton Textile Industry", Journal of Legal Studies, XXXIX, (January 2000): 181-182.

[367] Yamaguchi, 465.

[368] Eigyo Hokokusho, The Kannebuschi Spinning Company, July 1903, January,1904.

[369] Kanebo Kabushikikaisha, 12.

[370] Kanebo Kaushikikaisha, 21.

[371] Kanebo Kabushikikaisha, 31.

[372] Zenkoku Kabunushi Yoran.

[373] Yamaguchi, 472; Japan Industrial Bank, Shasai Ichiran, 187.

[374] Yamaguchi, 482-483; Japan Industrial Bank, Shasai Ichiran, 187.

[375] Kanebo Kabushikikaisha, 30-31.

[376] Yamaguchi, 45.

[377] Nakamigawa was born in a samurai house in 1854. After working as a public official, he worked for the Sanyo Railway and built a reputation as a business man In 1891, he joined the Mitsui group.(Kanebo Kabushikikaisha, 32) ; Asabuki was born in a commercial house in 1849. He joined the Mitsui after working for the Mitsubishi and other trading company. (Kanebo Kabushikikaisha, 33).

[378] Yamaguchi, 472.

[379] Kanebo kabushikikaisha, 76.

[380] Yamaguchi, 474.

[381] Kanebo Kabushikikaisha, 105-106.

[382] ibid.

[383] Yamaguchi, 17-21.

[384] Mitsui Ginko, 403-405. 
[385] Kanebo Kabushikikaisha, 78.

[386] Yamaguchi, 483.

[387] Mitsui Ginko, 173.

[388] Kanebo Kabushikikaisha, 116-7.

[389] Michael L. Gerlach, “ The Organizational Logic of Business Groups: Evidence from the Zaibatsu", in Beyond the Firm: Business Groups in International and Historical Perspective, ed. Takeo Shiba and Masahiro Shimotani, (New York: Oxford University Press, 1997): 270.

[390] The Encyclopedia of the Social Sciences, vol .7, $1^{\text {st }}$ ed., s.v. "Holding Company".

[391] ibid.

[392] ibid.

[393] ibid.

[394] Meade, 30.

[395] Hidy Ralph W. Hidy and Muriel E. Hidy, Pioneering in Big Business 1882-1911, (New York, Harper \& Brothers, 1955): 49.

[396] ibid.

[397] Meade, 38.

[398] Meade, 38.

[399] Hidy and Hidy, 308-311.

[400] Hidy and Hidy, 218.

[401] Hidy and Hidy, 225.

[402] Hidy and Hidy, 223-225.

[403] Hidy and Hidy, 226-228.

[404] Meade, 35.

[405] ibid.

[406] Chandler, The Visible Hand, 173-174. 
[407] Bonbright and Measn, 235-236.

[408] Chandler, The Visible Hand, 241.

[409] Bonbright and Means, 13.

[410] The Encyclopedia of the Social Sciences, vol. 7, !st ed., s.v. "Holding Company".

[411] ibid.

[412] ibid.

[413] Dewing, The Financial Policy of Corporation, IV, 127.

[414] Dewing, The Financial Policy of Corporation, IV, 126.

[415] Dewing, The Financial Policy of Corporations, 1, $72-74$.

[416] Field, Kenneth, Corporation Finance, (New York, the Ronald Press, 1938): 356.

[417] Field, 356.

[418] Bonbright, 15-18.

[419] Moody, 439-440.

[420] Moody, 380.

[421] Moody, 487.

[422] Moody, 453-569.

[423] Meade, 340.

[424] Leonard, 36.

[425] The company was established by prominent financiers and industrialists such as J. P Morgan, E.H Harriman, James J. Hill, and John D. Rockefeller. It was a pure holding company controlling Northern Pacific Railway, Great Northern Railway, and Chicago, Burlington, and Quincy Railroad.(Leonard, 37: Meade, 340).

[426] Leonard, 38; Bonbright. 74.

[427] Thomas K. McCraw, Prophets of Regulation, (Cambridge: Mass., Harvard University Press, 1970): 147. 
[428] McCraw, 141-149.

[429] McCraw, 144; Bonbright ,75; McCraw, 144.

[430] Leonard, 9.

[431] Bonbright and Means, 253-259.

[432] Bonbright and Means, 259.

[433] Bonbright and Means, 253-259.

[434] Clemens, 489.

[435] Clemens, 487-491.

[436] Dewing, The Financial Policy of Corporation, IV, 124-125.

[437] Bonbright, 12.

[438] Bonbright, 108-113.

[439] Bonbright, 93.

[440] The Encyclopedia of the Social Sciences, vol. 7, !st ed., s.v. "Holding Company".

[441] ibid.

[442] Bonbright, 91-92.

[443] The Encyclopedia of the Social Sciences, vol. 7, !st ed., s.v. "Holding Company".

[444] Bonbright and Means, 224.

[445] Bonbright and Means, 225.

[446] ibid.

[447] Bonbright and Means, 225-226.

[448] Hugh Bullock, The Story of Investment Companies, (New York: Columbia Unversity Press, 1959): 26; Theodore J. Grayson, Investment Trusts: Their Origin, Development, and Operation, (New York: John Wiley \& Sons, Inc., 1928), 286.

[449] Berle and Means, 115.

[450] Berle and Means, 73. 
[451] Berle and Means, 76.

[452] Berle and Means, 77.

[453] Berle and Means, 115.

[454] Keiichiro Nakagawa, "Industrial Structure and Entrepreneurial Performance of Pre-WW II Japan", [Dainiji Taisenmae no Nihon ni okeru Sangyokozo to Kigyosha Katsudo: Kansetsukinyu Taisei to Sogo Shosha wo Chushin ni] , Journal of Mitsui Research Institute for Social and Economic History, Tokyo, (1970), no.4: 89; Hiroshi Matsumoto Mitsui Zaibatsu,[Mitsui Zaibatsu no Kenkyu], (Tokyo: Yoshikawa Kobunkan, 1979):3; Kanji Ishii, Industrialization and Zaibatsu in Japan, [Nihon no Sangyoka to Zaibatsu], (Tokyo; Iwanami Shoten,1992):5; Kazuo Shibagaki, the Analysis of Japanese Financial Capital, [Nihon Kin'yu Shihon Bunseki], (Tokyo, Tokyo University Press, 1965): 141.

[455] G. Kurgen-Van Hentenryk, "Structure and Strategy of Belgian Business Group 1920-1990", in Beyond the Firm, edited by Takao Shiba and Masahiro Shimotani, 88106, (New York: Oxford University Press, 1997).

[456] Hidemasa Morikawa, Zaibatsu: The Rise and Fall of Family Enterprise Groups in Japan, (Tokyo: University of Tokyo Press, 1992): 3.

[457] Nakagawa, 198.

[458] Shibagaki, 55-64; Mishima, Yasuo, History of Mitsubishi Zaibatsu in the Meiji Period, [Mitsubishi zaibatsu shi:Meiji-hen], (Tokyo, Kyoiku sha, 1979): 36-49; Morikawa, 70.

[459] Mataji Miyamoto, History in the management in the Sumitomo, [Sumitomo no Keieishiteki Kenkyu], (Tokyo: Jitsumu Shuppan, 1979):182-184.

[460] Morikawa, 32, 38-9.

[461] Morikawa, 116.

[462] Miyamoto, 81.

[463] Morikawa, 116-117.

[464] Yasuoka, Shigeaki, Mistui Zaibatsu, [Mistui Zaibatsu], (Tokyo: Japan Economic Journal, 1982): 83-84.

[465] Shibagaki, 105.

[466] Morikawa, 60-65. 
[467] Morikawa, 64.

[468] Nakagawa, 204-5.

[469] Shigeaki Yasuoka, , History of the Management of Zaibatsu, [ Zaibatsu Keieishi no Kenkyu], (Tokyo: Minerva shobo, 1970): 310; Shibagaki, 36-7.

[470] Hiroshi Matsumoto, "The Development of Mitsui Bussan Kaisha in the 1900's", [Nihon Shihonshugi Kakuritsuki ni okeru Mitsui Bussan Kaisha no Hatten], Journal of Mitsui Research Institute for Social and Economic History, no.7, (November. 1973): 190.

[471] Matsumoto, “The Development of Mitsui Bussan Kaisha in the 1900's”, 143, 180181.

[472] Matsumoto, "The Development of Mitsui Bussan Kaisha in the 1900's", 159-176.

[473] Mitsui Archives, History of the Mitsui business, [Mitsui Jigyo-shi], 1, (Tokyo, Mitsui Archives, 1980): 520.

[474] The family constitution of he Mitsui in 1900 transferred the function of the Mitsui Omotokata to the Mitsui Dozoku-kai in 1900. (Mitsui Archivesi, Mitsui Jigyoshi, 1: 540).

[475] The Encyclopedia of the Social Sciences, vol. 7, 1st ed., s.v. "Holding Company".

[476] Mitsui Archives Mitsui Jigyo-shi, 1: 747-8; Yutaka Kasuga, The Development of the Mitsui PartnershipComapny [Mitsui Gomei Kaisha no Seiritsu Katei], Journal of Mitsui Research Institute for Social and Economic History, 113, (1979): 168-167.

[477] Hiroshi Matsumoto, "Formation of Mitsui Gomei Kaisha", [Mitsui Gomei Kaisha no Hatten to Shihon Kozo-1909-1922], Journal of Mitsui Research Institute for Social and Economic History, 5, (1971): 82-83.

[478] Matsumoto, "Formation of Mitsui Gomei Kaisha", 89.

[479] Matsumoto, "Formation of Mitsui Gomei Kaisha", 91; Before 1914,the exchange rate of the yen to the dollar was 2yen per \$1.00, (R.L. Bidwell, Currency Conversion Tables: A Hundred Years of Change, (London: Rex Collings, 1970): 55).

[480] Matsumoto, "Formation of Mitsui Gomei Kaisha", 112-115.

[481] Matsumoto, "Formation of Mitsui Gomei Kaisha", 100-103.

[482] Matsumoto, "Formation of Mitsui Gomei Kaisha", 104.

[483] Morikawa, 46. 
[484] Shoichi Asajima, Financial Structure of Mitsubishi Zaibatsu, [Mitsubishi Zaibatsu no Kin'yu Kozo], (Tokyo, Ochanomizu Shobo, 1986): 10.

[485] The self-supporting accounting system means that each department financed its expenditure by its income.

[486] Morikawa, 95.

[487] Mitsui Jigyo-shi,vol.2, 261; Morikawa, 12; Matsumoto, "Formation of Mitsui Gomei Kaisha", 116; electrical industries include electric power, electric railway, and various electrical manufacturing activities, including electrical ,chemicalsproducts, electric wire, and electric chemical products. (Morikawa, 118).

[488] The Mitsui Goshi owned all shares of the Mitsui Mining. It paid $¥ 10$ million in 1914 and a half million in 1917 out of $¥ 20$ million of capitalization.

[489] According to Bidwell, the exchange rate of the yen to the dollar was 2 yen per $\$ 1.00$ from pre war years to January, 1923. (Bidwell, Currency Conversion Tables: A hundres Years of Change, (London: Rex Collings), 1970: 55).

[490] Mishima, Yasuo, History of Mistubishi Zaibatsu during the Taisho and Showa periods, [Mitsubishi Zaibatsushi-Taisho, Showa hen], (Tokyo: Kyoikusha, 1980): 62-63.

[491] Matsumoto, "Formation of Mitsui Gomei Kaisha", 117.

[492] Mishima, History of Mistubishi Zaibatsu during the Taisho and Showa periods, 1980, 63; Koyata and Hisaya Iwasaki were the sons of Yanosuke and Yataro Iwasaki respectively.

[493] Matsumoto, “Formation of Mitsui Gomei Kaish”, 133-134.

[494] Mitsui Archives, Mitsui Jigyo-shi 2, 450.

[495] Asajima, 268-269.

[496] Asajima,32-33 Table 5; 36-37, Table 73.

[497] Asajima, 36-37, Table 7.

[498] Foreign Business in Japan before World War II, Takashi Yuzawa and Masaru Udagawa ed., (Tokyo: Tokyo University Press, 1990).

[499] R.P.T. Davenport Hines and Geoffrey Jones, British Business in Asia since 1860, (Cambridge: Cambridge University Press, 1990).

[500] Asajima, 282. 
[501] Mira Wilkins, The Maturing of Multinational Enterprise: American Business Abroad from 2924 to 1917, (Cambridge: Mass., Harvard University Press, 1974): 213.

[502] Asajima, 128.

[503] Yasuoka, 260.

[504] Morikawa,161.

[505] Kikkawa, 68.

[506] Kikkawa, 70-71; Hiroshi Yoshikawa, "Underwriting Business in the Mitsui Bank" [Mitsui Ginko no Shasai Uketsuke], Journal of Mitsui Research Institute for Social and Economic History, 28, (1994): 84-85.

[507] Kikkawa. 83, 106-107. 


\section{BIBLIOGRAPHY}

\section{Primary Sources: Annual Reports}

Annual Reports: The American Telephone \& Telegraph Company

Annual Reports: The Pennsylvania Railroad Company

Annual Reports: The United States Steel Corporation

Eigyo Hokokusho: The Kanebuchi Spinning Company

Eigyo Hokokusho: The Nihon Railway Company

Eigyo Hokokusho: The Tokyo Electric Light Company

\section{Primary Sources: Newspapers}

Commercial and Financial Chronicle

Moody's Analyses of Railroad Investment

New York Times

\section{Primary Sources: Printed Primary Sources}

A Short History of Foreign Bonds in Japan [Nihon Gaisai Shoshi], Tokyo: Japan Industrial Bank, 1948.

List of Corporate bonds, [Shasai Ichiran], Tokyo: Japan Industrial Bank, 1970.

List of Shareholders, [Zenkoku Kabunushi Yoran], Tokyo: Diamond Sha,1921.

Francis Former, "Address", In Public Utility Finance, edited by Walter Lagerquist, Chicago and New York: A.W. Shaw Company, 1927.

Iwakura, Tomomi, "Letter to Tokumei Zenken Daihukushi” Nov.3, 1872, in Iwakura-ko Jikki, 1968.

Ikeda, Seihin, Memory of the Financial Circle, [Zaikai Kaiko], Tokyo; Sekai no Nihon Sha, 1949. 


\section{Primary Sources: Official Document}

Hearings before the Temporary National Economic Committee, Congress of the United States Seventy-Six Congress First Session, Investigation of Concentration of Economic Power, Part 9.

Annual Statistics in Japan, [Nihon Teikoku Tokei Nenkan], edited by Naikaku Tokei Kyoku.

\section{Secondary Sources: Books}

Arai, Shinji, Yokohama Shokin Ginko Zenshi, [History of Yokohama Specie Bank], Tokyo: Toyo Keizai Shinpo sha, 1981.

Asajima, Shoichi, Financial Structure of Mitsubishi Zaibatsu, [Mitsubishi Zaibatsu no Kin'yu Kozo], Tokyo:Ochanomizu Shobo, 1986.

Berglund, Abraham, The United States Steel Corporation: A Study of the Growth and Influence of Combination in the Iron and Steel Industry, New York the Columbia University Press, 1907.

Berle, Adolf A. Jr., The Modern Corporation and Private Property, New York: The Macmillan Company, 1932.

Bidwell, R.L., Currency Conversion Tables: A Hundred Years of Change, London: Rex Collings, 1970.

Bogen, Jules I. , Analysis of Railroad Securities : A Guide to the Determination of Investment Values, New York, the Ronald Press, 1928.

Bonbright, James C. and Gardiner Means, The Holding Company: Its Public Significance and Its Regulation, New York: McGraw-Hill Book Company, 1932.

Bonbright, James C., Public Utilities and the National Power Policies, New York: Columbia University Press.1940.

Bullock, Hugh, The Story of Investment Companies, New York: Columbia University Press, 1959.

Burgess, George H. and Miles C. Kennedy, Centennial History of the Pennsylvania Railroad Company, 1846 to 1946, Philadelphia: Arno Press, 1979.

Campbell, Edward G., Reorganization of the American Railroad System, 1893-1900, New York: Columbia University Press, 1938. 
Carosso, Vincent P., Investment Banking in America, Cambridge, Mass.: Harvard University Press, 1970.

Carosso, Vincent P., The Morgans: Private Investment Bankers, 1854-1913, Cambridge: Mass., Cambridge University, 1987.

Chandler, Alfred D. Jr., Scale and Scope: The Dynamics of Industrial Capitalism, Harvard University Press, Cambridge: Mass., 1990.

Chandler, Alfred D., The Visible Hand: The Managerial Revolution in American Business, Harvard University Press, Cambridge: Mass., 1977.

Chernow, Ron, The House of Morgan: An American Banking Dynasty and the Rise of Modern Finance, New York: Atlantic Monthly Press, 1990.

Clemens, Eli Winston, Economics and Public Utilities, New York: Appleton-CenturyCrofts, Inc., 1950.

Cleveland, Frederick A. and Fred Wilber Powell, Railroad Promotion and Capitalization in the United States, New York: Longmans, Green, and Co., 1909.

Cleveland, Frederick A. and Fred Wilber Powell, Railroad Finance, New York: D. Appleton and Company, 1912.

Coon, Horace, American Tel. and Tel.: The Story of A Great Monopoly, Freeport: New York, Books for Libraries Press, 1939.

Dewing Arthur S., Corporate Promotion and Reorganization, Cambridge: Mass., Harvard University Press, 1914.

Dewing Arthur S., The Financial Policy of Corporations, Vol. 1, New York, The Ronald Press, 1919.

Dewing Arthur S., The Financial Policy of Corporations, Vol. 2, New York, The Ronald Press, 1919.

Dewing Arthur S., The Financial Policy of Corporations, Vol. 3, New York, The Ronald Press, 1920.

Dewing Arthur S., The Financial Policy of Corporations, Vol. 4, New York, The Ronald Press, 1920.

Dewing Arthur S., The Financial Policy of Corporations, Vol. 5, New York, The Ronald Press, 1920. 
Ebasco Service Incorporated, Electric Utility Financing, New York: Ebasco Service Incorporated, 1948.

Edward S. Meade, Trust Finance: A Study of the Genesis, Organization, and Management of Industrial Combinations, New York: D. Appleton and Company, 1903.

Field, Kenneth, Corporation Finance, New York, the Ronald Press, 1938.

Garnet, Robert W., The Telephone Enterprise: The Evolution of the Bell System's

Horizontal Structure, 1876-1909, Baltimore: John Hopkins University Press, 1985.

Gerschenkron, Alexander, Economic Backwardness in Historical Perspective, Cambridge: Mass.,Harvard University Press, 1962.

Grayson, Theodore J., Investment Trusts: Their Origin, Development, and Operation, New York: John Wiley \& Sons, Inc., 1928.

Hausman William, Peter Hertner, and Mira Wilkins, Global Electrification: Multinational Enterprise and International Finance in the History of Light and Power, 1878-2007, Cambridge: Cambridge University Press, 2008.

Hoshi, Takeo, and Kashyap, Anil, Corporate Finance and Governance in Japan: The Road to the Future, Cambridge: Mass., The MIT Press, 2001.

Howell, David L., Capitalism from Within: Economy, society, and State in a Japanese Fishery, Berkeley University of California Press, 1995.

Hidy Ralph W. and Muriel E. Hidy, Pioneering in Big Business 1882-1911, New York: Harper \& Brothers, 1955.

Hines, Davenport R.P.T. and Geoffrey Jones, British Business in Asia since 1860, Cambridge: Mass., Harvard University Press, 1989.

Ishihama, Tomoyuki, Theory of Financial Organization, [Tokushu Kin'yu Kikanshi ron], Tokyo, Iwanami Shoten 1992.

Ishii, Kanji, Industrialization and Zaibatsu in Japan, [Nihon no Sangyoka to Zaibatsu], Tokyo: Iwanami Shoten, 1992.

Kanebo Kabushikikaisha, History of Kanebo [Kanebo Hyakunenshi], Tokyo: Kanebo Kabushikikaisha, 1988.

Kataoka, Yutaka, Railroads and the Securities Market, [Tetsudo Kigyo to Shoken Shijo], Tokyo, Nihon Keizai Hyoronsha, 2006. 
Kikkawa Takeo, The Development of Electric Power and Yasuzaemon Matsunaga, [Nihon Denryoku no Hatten to Masunaga Yasuzaemon], Nagoya: Nagoya Daigaku Shuppankai, 1995.

Koch, Albert Ralph, The Financing of Large Corporations, 1920-1929, New York: National Bureau of Economic Research, 1943.

Kurihara, Toyo, Denryoku, Tokyo: Kojyunsha, 1964.

Kurusu, Tekeo, History of the Japanese Financial System, [Nihon Kin'yu Seido Hattatsu no Kenkyu], Tokyo, Keimeisha, 1930.

Lagerquist, Walter E, Public Utility Finance, Chicago and New York: A.W. Shaw Company, 1927.

Lamoreaux, Naomi R., The Great Merger Movement in the American Business 18951904, Cambridge: Mass., Cambridge University Press, 1985.

Leonard, William, Railroad Consolidation under the Transportation Act of 1920, New York: AMS Press, 1968.

Lockwood William W., The Economic Development of Japan: Growth and Structural Change, Princeton, Princeton University Press, 1968.

Martin, Albro, Enterprise Denied: Origins of the Decline of American Railroad, 18971917, New York: Columbia University, 1971.

Marx, Karl, Capital: A Critique of Political Economy, Moscow: Foreign Language Publishing House, 1867.

Masaki, Hisashi, Corporate Finance in Japanese Joint-Stock Companies, [Nihon no Kabushikikaisha Kin'yu], Tokyo: Mineruva Shobo, 1973.

Mason, Mark, American Multinationals and Japan: The Political Economy of Japanese Capital Controls, 1899-1980, Cambridge: Mass., Harvard University Press, 1992.

Matsumoto, Hiroshi, Mitsui Zaibatsu,[Mitsui Zaibatsu no Kenkyu], Tokyo: Yoshikawa Kobunkan, 1979.

McCraw, Thomas K. Prophets of Regulation, Cambridge: Mass., Harvard University Press, 1970.

Meade, Edward Sherwood, Trust Finance: A Study of Genesis, Organization, and Management of Industrial Combinations, New York: D. Appleton and Company, 1905. 
Michie, Ronald C., The London and New York Stock Exchange, 1850-1914, Boston: Allen \& Unwin, 1987.

Mishima, Yasuo, History of Mitsubishi Zaibatsu during the Taisho and Showa periods, [Mitsubishi Zaibatsushi-Taisho, Showa hen], Tokyo: Kyoikusha, 1980.

Mitsui Archives, History of the Mitsui business, [Mitsui Jigyo-shi],Tokyo: Mitsui Archives, 1980.

Mitsui Ginko, History of Mitsui Bank, [Mitsui Ginko Hachijunenshi], Tokyo: Mitsui Ginko, 1957.

Miyamoto, Mataji, History in the Management in the SumitomoGroup, [Sumitomo no Keieishiteki Kenkyu], Tokyo: Jitsumu Shuppan, 1979.

Moody, John, The Masters of Capital: A Chronicle of Wall Street, New Haven: Yale University Press, 1919.

Moody, John, The Truth about the Trust: A Description and Analysis of the American Trust Movement, New York: Moody Publishing Company, 1904.

Morikawa, Hidemasa, Zaibastu: The Rise and Fall of Family Enterprise Groups in Japan, Tokyo: University of Tokyo Press, 1992.

Mundy, Floyd W. The Value of a Railroad Security, Boston: American Institute of Finance, 1922.

Nakayama, Ichiro, Watanabe, Ichiro, Sokuichi Kotake, and Mitsuo Kawada, Centennial History of Electric Utilities, [Denryoku hyakunenshi], Tokyo: Seikeisha, 1980.

Nitta, Muneo, History of the Tokyo Electric Light Company, [Tokyo Dento Kabushiki Kaisha Kaigyo Gojunenshi], Tokyo: Tokyo Electric Light Company, 1936.

Noda, Masaho, History of the Development of the Ssecurities Market in Japan, [Nihon Shoken Shijo Seiristushi],Toky: Yuhikaku,1980.

Noda, Masaho, History of the Nihon Railway Company, [Nihon Tetsudo Kabushiki Kaisha Enkakushi] Tokyo: Nihon Hyoronsha, 1980.

Nomura, Jun'nosuke, History of Japanese Capital,[Nihon Kin'yu Shihon Hattatsu shi], Tokyo: Kyoseikakuhan,1931.

Roe, Mark J., Strong Managers, Weak Owners: The Political Roots of American Corporate Finance, Princeton: Princeton University Press, 1994. 
Saliers, Earl Adolphus, Principle of Depreciation, New York: The Ronald Press Co., 1916.

Scranton, Philip, Endless Novelty: Specialty Production and American Industrialization 1865-1925, Princeton: Princeton University Press, 1997.

Shibagaki, Kazuo, The Analysis of Japanese Financial Capital, [Nihon Kin'yu Shihon Bunseki], Tokyo: Tokyo University Press, 1965.

Stehman, Warren, The Financial History of the American Telephone and Telegraph Company, New York: Augustus M. Kelley Publishers, 1967.

Takamura, Naosuke, History of Cotton Spinning Industry in Japan, [Nihon Bosekigyo shi], Tokyo: Hanawa Shobo, 1971.

Temin, Peter, The Fall of the Bell System: A Study in Prices and Politics, Cambridge, Mass,: Cambridge University Press, 1987.

Tokyo Stock Exchange, History of Tokyo Sotck Exchange, [Toyko Kabushiki Torihikijo Gojunenshi], Tokyo: Tokyo Stock Exchange, 1928.

Toyo Keizai Shinpo Sha, Sixty-Year History of Finance, [Kin'yu Rokuju-nen shi], Tokyo: Toyo Keizai Shinpo Sha, 1924.

Veenendaal, Augustus J. Jr., Slow Train to Paradise: How Dutch Investment Helped Build American Railroad, Stanford: Stanford University Press, 1996.

Walton, Gary M. and Hugh Rockoff, History of the American Economy, Fort Worth, The Dayden Oress, 1998.

Wilkins, Mira, The Maturing of Multinational Enterprise: American Business Abroad from 1914 to 1970, Cambridge: Mass., Harvard University Press, 1974.

Wilkins Mira, The History of Foregn Investment in the United States to 1914, Cambridge: Mass., Harvard University Press, 1989.

Wilkins Mira, The History of foreign Investment in the United States, 1914-1945, Cambridge: Mass., Harvard University Presss, 2004.

Yamaguchi Kazuo, History of Corporate Finance in Japan: Spinning, [Nihon Kin'yushi Kenkyu: Orimono Kin'yu hen] , Tokyo: Tokyo Daigaku Shuppankai, 1974.

Yasuoka, Sshigeaki, History of the Management of Zaibatsu, [Zaibatsu Keieishi no Kenkyu], Tokyo: Minerva shobo, 1970.

Yasuoka, Shigeaki, “Mistui Zaibatsu”, [Mitsui Zaibatsu], Tokyo: Japan Economic Journal, 1982, 83-84. 
Zysman, John, Governments, Markets, and Growth: Financial Systems and the Politics of Industrial Change, Itacha: Cornell University Press, 1983.

\section{Secondary Sources: Articles and Chapters in Edited Works}

Bernstein, Jeffery R., “Japanese Capitalism”, In Creating Modern Financial Capitalism: How Entrepreneurs, Companies, and Countries Triumphed in Three Industrial Revolutions, edited by Thomas McCraw, 439-489, Cambridge: Mass.,Harvard University Press, 1997.

Carlin, Wendy and Colin Mayer, "How Do Financial Systems Affect Economic Performance?", In Corporate Governance: Theoretical and Empirical Perspectives, edited by Xavier Vives, 137-166, Cambridge: Mass., Cambridge University Press, 2000.

Cull, Robert, Lance E. Davis, Naomi R. Lamoreaux, and Jean-Laurent Rosenthal, "Historical Financing of Small and Medium-Sized Enterprises", Working Paper 11895, National Bureau of Economic Research, 2005.

De Long, J. Bradford, “Did J.P Morgan's Men Add Value?: A Historical Perspective on Financial Capitalism", Working Paper No. 3426, National Bureau of Economic Research, Inc, 1990.

Dixon, Frank Haigh, "The Economic Significance of Interlocking Directorates in Railway Finance," The Journal of Political Economy, 22, no. 10, (December), 1914: 937954.

Evans, George Heberton, "The Early History of Preferred Stock in the United States," The American Economic Review, 10, no.1 (March, 1929): 43-58.

Fohlin, Caroline, "Does Civil Law Tradition and Universal Banking Crowd Out Securities Markets? Pre-World War I Germany as Counter-Example", Enterprise \&Society, (September, 2008): 602-641.

Gerlach, Michael L., “ The Organizational Logic of Business Groups: Evidence from the Zaibatsu", In Beyond the Firm: Business Groups in International and Historical Perspective, edited by Takeo Shiba and Masahiro Shimotani, 245-273 (New York: Oxford University Press, 1997).

Hailman, Ralph E., "Customer Ownership of Public Utilities", In Public Utility Finance, edited by Walter E. Lagerquist, 187-194, Chicago and New York: A. W. Show, 1927.

Hall, Peter A., "The Political Economy of Europe in an Era of Independence", In Continuity and Change in Contemporary Capitalism, edited by Herbert Kishelt, Peter Lange, Gary Marks, and John Stephens, 135-163, Cambridge: Mass., Cambridge University Press, 1999. 
Hollingsworth,J. Rogers, "Continuities and Change in Social System of Production: The Case of Japan, Germany, and the United States", In Contemporary Capitalism: The Embeddedness of Institutions, edited by J. Rogers Hollingsworth and Robert Boyer, 265310, New York: Cambridge University Press, 1977.

Hollingsworth, J. Rogers and Robert Boyer, In " Coordination of Economic Actors and Social System of Production: The Embeddedness of institutions", edited Hollingsworth and Boyer, 1-18, 1977.

Hoshi, Takeo, Anil Kashyap, and David Scharfstein, "Bank Monitoring and Investment: Evidence from the Changing Structure of Japanese Corporate Banking Relationship”, National Bureau of Economic Research Working Paper Series, no. 3079, 1989.

Houtman-Smedt, Helma "The Banking System in Belgium through the Centuries", In Handbook on the History of European Banks, edited by Manfred Poul, 47-94 Brookfield: Var., 1994.

Jensen, Michael, C., "Eclipse of the Public Corporation", Harvard Business Review, (September 1989 revised in 1997), http://papers.ssrn.com/abstract=146149.

Kang, Jung-Koo and Rene M. Stulz, "Is Bank-Centered Corporate Governance Worth It? A Cross-Performance of Japanese Firms during the Assets Price Deflation", National Bureau of Economic Research Working Paper Series, no. 6238, Cambridge: Mass., 1996.

Kasuga, Yutaka, "The Development of the Mitsui PartnershipComapny", [Mitsui Gomei Kaisha no Seiritsu Katei], Journal of Mitsui Research Institute for Social and Economic History, 113, (1979): 89-191.

Keister, Albert S., "Recent Tendency in Corporate Finance", The Journal of Political Economy, 30, no.2, (April.1922): 257-273.

Kishelt, Herbert. Peter Lange, Gary Marks, and John Stephens, "Convergence and Divergence in Advanced Capitalist Democracies", In Continuity and Change in Contemporary Capitalism, edited by Herbert Kishelt, Peter Lange, Gary Marks, and John Stephens, 427-460, Cambridge: Mass., Cambridge University Press, 1999.

Kurgan-Van, Hentenryk, G., "Structure and Strategy of Belgian Business Group 19201990", In Beyond the Firm, edited by Takao Shiba and Masahiro Shimotani, 88-106, New York: Oxford University Press, 1997.

Litner, John "The Financing of Corporations", In The Corporation in Modern Society, edited by Edward S. Mason, 167-210, Cambridge: Mass., Harvard University Press, 1961. 
Matsumoto, Hiroshi, “The Development of Mitsui Bussan Kaisha in the 1900's", [Nihon Shihonshugi Kakuritsuki ni okeru Mitsui Bussan Kaisha no Hatten], Journal of Mitsui Research Institute for Social and Economic History, no.7, (1973): 107-199.

Matsumoto, Hiroshi, "Formation of Mitsui Gomei Kaisha", [Mitsui Gomei Kaisha no Hatten to Shihon Kozo-1909-1922], Journal of Mitsui Research Institute for Social and Economic History, 5, (1971): 89-219.

Matsushima, Harumi, "The Historical Importance of the Flotation of Foreign Loan of the Power Indsutry", [Denryoku Gaisai no Rekishiteki Igi], Shakai Keizaigaku, 26-6, (1961): $399-438$.

Miwa, Yoshiro and J. Mark Ramseyer, "Corporate Governance in Transitional Economies: Lessons from the Prewar Japanese Cotton Textile Industry", Journal of Legal Studies, XXXIX, (January 2000): 171-201.

Miwa, Yoshiro, and J. Mark Ramseyer, "Banks and Economic Growth: Implications from Japanese History", Journal of Law and Economics, (April 2002): 127-164.

Miyajima, Hideaki, "The impact of Deregulation on Corporate Governance and Finance", In Is Japan Really Changing Its Way?: Regulatory Reform and the Japanese Economy, edited by Lonny E. Carlie and Mark C. Tilton, 33-75, Brooks Institution Press, Washington D.C., 1998.

Morck, Randall K. and Lloyd Steier, "The Global History of Corporate Governance: An Introduction" In Morck A History of Corporate Governance around the World, edited by Morck, 1-64, Chicago: The University of Chicago Press, 2005.

Morck, Randall, Masao Nakamura, and Anil Shivdasani, "Banks, Ownership Structure, and Firm Value in Japan”, Journal of Business, 73 (October 2000): 539-569.

Nakagawa, Keiichiro, "Industrial Structure and Entrepreneurial Performance of Pre-WW II Japan", [Dainiji Taisenmae no Nihon ni okeru Sangyokozo to Kigyosha Katsudo: Kansetsukinyu Taisei to Sogo Shosha wo Chushin ni], Journal of Mitsui Research Institute for Social and Economic History, no. 4.(1970): 189-213.

Nakamura, Naofumi, Introduction to the Mihon Railway; or, The Nihon TesytudoGedai, In Eigyo Hokokusho Shusei, The Nihon Railway Company, i-xvi.

Laporta, Rafael, Franco Lopez-de Silanes, Andrei Schleifer, and Robert Vishny, "Corporate Ownerhship Around the World", In the Journal of Finance, LIV, no.2, (April, 1999): 471-517.

Roe, Mark "Political Precondition to Separating Ownership from Corporate Control", Standard Law Review, 53. (December 2000): 539-606. 
Sylla, Richard and George David Smith, "The Transformation of Financial Capitalism: An Essay on the History of American Capital Markets", Financial Markets, Institutions \& Instruments, 2, no.2, (May 1993): 1-62.

Sylla, Richard and George David Smith, "Capital Markets", In Encyclopedia of the United States in the Twentieth Century, 1209-1241, New York: Charles Scribner's Sons, 1996.

Udagawa, Masaru, "Business Management and Foreign-Affiliated Companies in Japan before World War II", In Foreign Business in Japan Before world War II, edited by Takeshi Yuzawa and Masaru Udagawa, Tokyo: University of Tokyo Press, 1990.

Weinstein, David E. and Yishay Yafeh, "On the Cost of a Bank-Centered Financial System: Evidence from Changing Main Banking Relation in Japan ", The Journal of Finance, 53, no. 2 (April 1998): 635-672.

Yoshikawa, Hiroshi, "Underwriting Business in the Mitsui Bank", [Mitsui Ginko no Shasai Uketsuke], Journal of Mitsui Research Institute for Social and Economic History, 28, (1994): 84-85. 


\section{GLOSSARY}

Blanket mortgage: A mortgage secured by the pledging of more than one property or collateral.

Closed-end mortgage: A method to issue mortgage bond. When specific property is pledged, no more bond can be issued having the same hold on it.

Collateral loans: Loans secured by property.

Collateral trust bonds: Bonds not secured as a lien on physical property but rather by a lien on securities deposited with a trustee as collateral.

Common stock: Security that represents ownership in a corporation. Common stockholders have voting right. When the company is liquidated, common stockholders have rights to receive company's assets only after bondholders, preferred shareholders, and other debt holders have been satisfied.

Convertible bonds: Bonds exchangeable for common or preferred stock in a certain time period after the issue.

Cumulative preferred stock: Preferred stock having the provision that if dividend payment is omitted, the unpaid dividends have to be paid to the preferred stockholders before common stockholders.

Debenture bonds: Bonds not secured by any pledge of property. The company merely promises to pay a certain sum of money at a given time.

Documentary bill: A kind of bill of exchange, which the seller of the product issued attached to bills of landing $(\mathrm{B} / \mathrm{L})$. When the buyer paid for the documentary bills, bills of landing are returned to the seller.

Dollar-dominated bonds: Dollar bonds that are traded inside and outside the United States. They reduced exchange risk for Americans.

Equity ratio: Ratio of capital stock to gross assets.

Equipment trust bonds: Bonds that are secured by some form of equipment. It is usually issued by railroad companies.

General and consolidated mortgage bonds: Bonds issued under the blanket mortgages, which come after all the preceding mortgages.

Income bonds: Bonds whose income is paid only when the company earned. 
Open-end mortgage: A method to issue mortgage bond, which permits the further issue of bonds with the same lien as those already outstanding. In the case of subsequent failure, the holders of all these issues stand on the same footing.

Preferred stock: Capital stock with fixed dividend that is paid before any dividends are paid to common stockholders. When the company is liquidated, preferred stock shareholders takes precedence over common stock. It sometimes has cumulative dividend and voting right provisions.

Promissory notes: Written promise to pay a certain amount of money on demand or at a specific time.

Receivers' certificate: Notes issued by corporate receivers. When a company passes into the control of the court, following threatened or actual default on its obligations, the court authorizes its agents or receivers to obtain money by issuing short-term notes.

Refunded bonds: Bonds issued to refund other debt.

Registered bonds: Bond whose owner is registered his name to the issuer.

Reserves: Portion of earnings set aside for future expenditure or for specified purposes.

Retained earnings: Sum of surplus and reserves.

Scrip dividend: Dividend paid in notes, scrip dividend divides the profits but defer the actual distribution of assets.

Sterling bond: Bond denominated in British pounds. This is issued to sell in Britain.

Stock collateral loans: Loan made by banks, which is pledged by stock as collateral.

Subsidiaries' notes: A short-term debt security issued by companies whose voting stock (more than 50 per cent) is controlled by a holding company.

Voting trust: An administrative device to maintain the executive or financial control of the company, The shareholders surrenders all control over the company to his trustees, who are entitled to exercise the right to vote for every purpose and to consent to any corporate act. Instead, the shareholder received a voting trust certificate, which entitled them to all the privilege of stock ownership except that of voting.

Source: Arthur S. Dewing, The Financial Policy of Corporations, New York, The Ronald Press, Vol. 1-III, 1919-1920; Yuhikaku Dictionary of Economic Terms [Yuhikaku Keizai Jiten], Tokyo, Yuhikaku, 1998. 
VITA

\section{YUMIKO MORII}

\section{EDUCATION}

2002 - 2008 Doctoral Candidate in History, Florida International University, Miami, FL 1999 - 2001 MA program: Economics, Indiana University, Bloomington

1997 - 1999 BA program: Economics, Kobe University, Kobe, Japan

1987 - 1991 BA program: German Literature, Jochi University, Tokyo, Japan

\section{PROFESSIONAL EXPERIENCE}

$2002-2006$

Teaching Assistant, History, Florida International University, Miami, FL

1997 - 1999

Administrative Assistant, Rokko Warehouse \& Transport Co., Kobe, Japan

$1991-1993$

Administrative Assistant, Marubeni Corporation, Tokyo, Japan

\section{PRESENTATIONS}

1. Kenneth Lipartito and Yumiko Morii, "Corporate Finance from Railroads to Public Utilities," presented by Lipartito, the $28^{\text {th }}$ Fuji Conference, Tokyo, Japan, (2006).

2. Yumiko Morii, "Varieties of Corporate Finance in Japanese Industrialization", the Southern Japan Seminar, Miami, Florida (2007). 